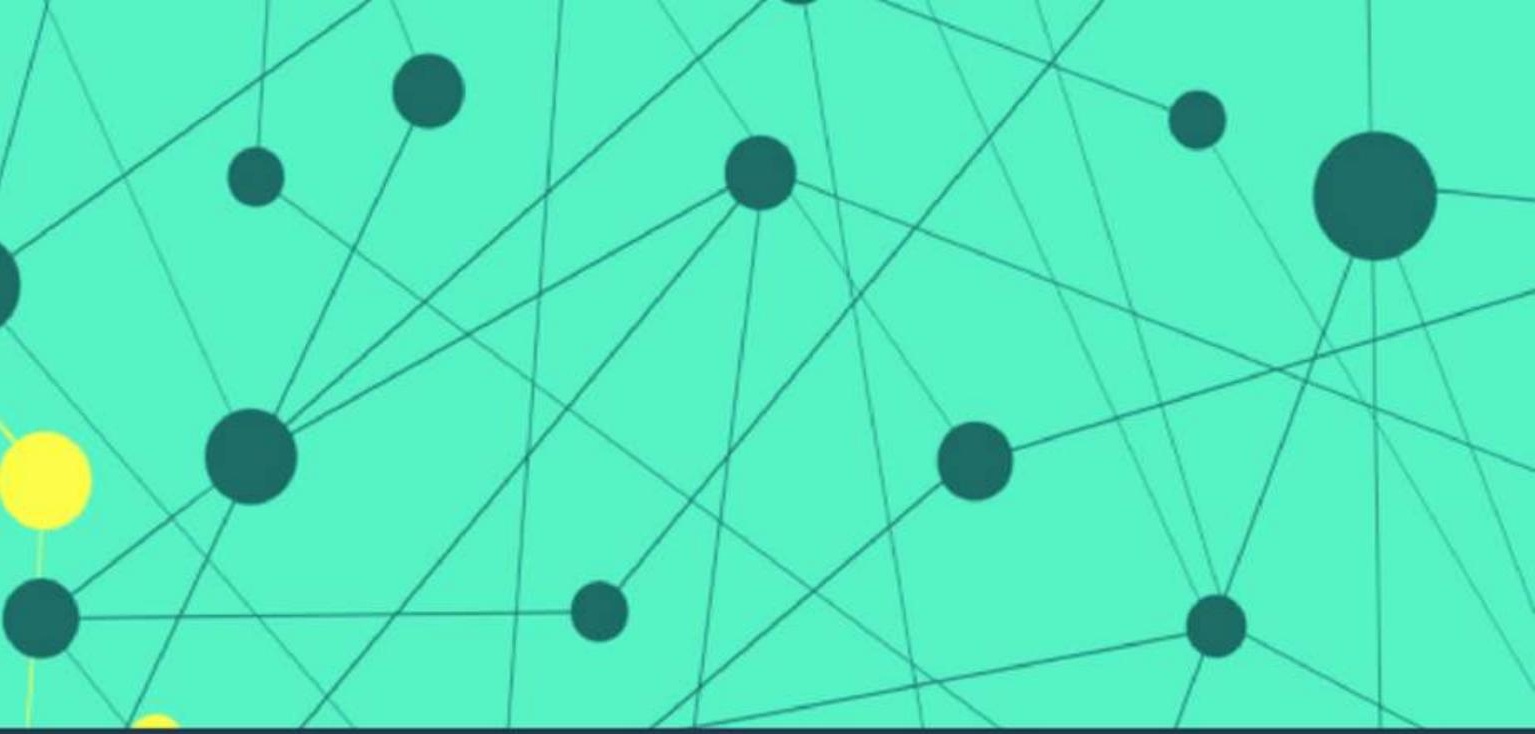

Routledge Studies in Development, Mobilities and Migration

\title{
EUROPE AND THE REFUGEE RESPONSE
}

A CRISIS OF VALUES?

\author{
Edited by \\ Elżbieta M. Goździak, Izabella Main \\ and Brigitte Suter
}

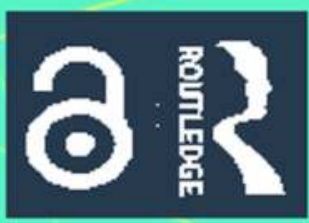




\section{Europe and the Refugee Response}

This book explores how the rising numbers of refugees entering Europe from 2015 onwards played into fears of cultural, religious, and ethnic differences across the continent. The migrant, or refugee crisis, prompted fierce debate about European norms and values, with some commentators questioning whether mostly Muslim refugees would be able to adhere to these values, and be able to integrate into a predominantly Christian European society. In this volume, philosophers, legal scholars, anthropologists, and sociologists analyze some of these debates and discuss practical strategies to reconcile the values that underpin the European project with multiculturalism and religious pluralism, whilst at the same time safeguarding the rights of refugees to seek asylum.

Country case studies in the book are drawn from France, Germany, Greece, Hungary, Italy, the Netherlands, Poland, Spain, Sweden, and the United Kingdom representing states with long histories of immigration, countries with a more recent refugee arrivals, and countries that want to keep refugees at bay and refuse to admit even the smallest number of asylum seekers. Contributors in the book explore the roles which national and local governments, civil society, and community leaders play in these debates and practices, and ask what strategies are being used to educate refugees about European values, and to facilitate their integration.

At a time when debates on refugees and European norms continue to rage, this book provides an important interdisciplinary analysis which will be of interest to European policy makers, and researchers across the fields of migration, law, philosophy, anthropology, sociology, and political science.

Elżbieta M. Goździak is a Visiting Professor at the Center for Migration Studies, Adam Mickiewicz University, Poland, a Research Professor at Oslo Met University, Oslo, Norway, and a Fellow for Refugee Engaged Scholarship at the Center for Social Justice, Georgetown University, USA.

Izabella Main is an Associate Professor of Ethnology and Anthropology of Culture, Adam Mickiewicz University in Poznań, Poland.

Brigitte Suter is a Senior Researcher at Malmö Institute for Studies of Migration, Diversity and Welfare (MIM) at Malmö University, Sweden. 


\section{Routledge Studies in Development, Mobilities and Migration}

This series is dedicated to the growing and important area of mobilities and migration, particularly through the lens of international development. It promotes innovative and interdisciplinary research targeted at a global readership. The series welcomes submissions from established and junior authors on cutting-edge and high-level research on key topics that feature in global news and public debate.

These include the so called European migration crisis; famine in the Horn of Africa; riots; environmental migration; development-induced displacement and resettlement; livelihood transformations; people-trafficking; health and infectious diseases; employment; South-South migration; population growth; children's wellbeing; marriage and family; food security; the global financial crisis; drugs wars; and other contemporary crisis.

Return Migration and Nation Building in Africa

Reframing the Somali Diaspora

Adele Galipo

Country Frameworks for Development Displacement and Resettlement Reducing Risk, Building Resilience

Edited by Susanna Price and Jane Singer

Migration, Development and Social Change in the Himalayas

An Ethnographic Village Study

Madleina Daehnhardt

Contemporary European Emigration

Situating Integration in New Destinations

Brigitte Suter and Lisa Åkesson

Europe and the Refugee Response

A Crisis of Values?

Edited by Elżbieta M. Goździak, Izabella Main and Brigitte Suter 


\section{Europe and the Refugee Response}

A Crisis of Values?

Edited by

Elżbieta M. Goździak, Izabella

Main and Brigitte Suter 
First published 2020

by Routledge

2 Park Square, Milton Park, Abingdon, Oxon OX14 4RN

and by Routledge

52 Vanderbilt Avenue, New York, NY 10017

Routledge is an imprint of the Taylor $\mathcal{E}$ Francis Group, an informa business

(C) 2020 selection and editorial matter, Elżbieta M. Goździak, Izabella Main and Brigitte Suter; individual chapters, the contributors

The right of Elżbieta M. Goździak, Izabella Main and Brigitte Suter to be identified as the author of the editorial material, and of the authors for their individual chapters, has been asserted in accordance with sections 77 and 78 of the Copyright, Designs and Patents Act 1988.

The Open Access version of this book, available at www.taylorfrancis.com, has been made available under a Creative Commons Attribution-Non Commercial-No Derivatives 4.0 license.

Trademark notice: Product or corporate names may be trademarks or registered trademarks, and are used only for identification and explanation without intent to infringe.

British Library Cataloguing-in-Publication Data

A catalogue record for this book is available from the British Library

Library of Congress Cataloging-in-Publication Data

Names: Goździak, Elźbieta M., 1954- editor. | Main, Izabella, editor. |

Suter, Brigitte, editor.

Title: Europe and the refugee response : a crisis of values? / edited by

Elzbieta M. Gozdziak, Izabella Main and Brigitte Suter.

Description: New York : Routledge, 2020.

Series: Routledge studies in development, displacement and resettlement |

Includes bibliographical references and index. |

Identifiers: LCCN 2019050384 (print) | LCCN 2019050385 (ebook) |

ISBN 9780367233266 (hardback) | ISBN 9780429279317 (ebook)

Subjects: LCSH: Immigrants--Europe--Social conditions. |

Europe--Emigration and immigration--Government policy. |

Minorities-Europe--Social conditions. | Europeans--Cultural

assimilation--Foreign countries. | Immigrants--Cultural assimilation. |

Europe--Ethnic relations.

Classification: LCC JV7590 .E8778 2020 (print) | LCC JV7590 (ebook) |

DDC 305.9/06914094--dc23

LC record available at https://lccn.loc.gov/2019050384

LC ebook record available at https://lccn.loc.gov/2019050385

ISBN: 978-0-367-23326-6 (hbk)

ISBN: 978-0-429-27931-7 (ebk)

Typeset in Goudy

by Taylor \& Francis Books 


\section{Contents}

List of illustrations vii

Acknowledgements ix

List of contributors $\quad \mathrm{x}$

1 European norms and values and the refugee crisis: issues and challenges

ELŻBIETA M. GOŹDZIAK AND IZABELLA MAIN

2 Echoes of memories of forced displacement: the case of the Greek island of Lesvos MARILENA ANASTASOPOULOU

3 Against the expansion of racism: the experience of the Camp des Milles

BERNARD MOSSÉ

4 The Moral Panic Button: construction and consequences MÁRTON GERÖ AND ENDRE SIK

5 Abolishing asylum and violating the human rights of refugees. Why is it tolerated?: the case of Hungary in the EU FELIX BENDER

6 Between closing borders to refugees and welcoming Ukrainian workers: Polish migration law at the crossroads WITOLD KLAUS

7 Debating deportation detention in Germany: the many faces of the rule of law JOHANNA CAROLINE GÜNTHER 
vi Contents

8 Integration by contract and the 'values of the Republic': investigating the French State as a value promoter for migrants (2003-2016)

MYRIAM HACHIMI ALAOUI AND JANIE PÉLABAY

9 Box-ticking exercise or real inclusion? challenges of including refugees' perspectives in EU policy

ROBERT LARRUINA AND HALLEH GHORASHI

10 Being a 'refuge-city': welcoming rhetorics in Paris and Barcelona LOUISE HOMBERT

11 Holding course: civil society organizations' value expressions in the Swedish legislative consultation system before and after 2015 ROBERTO SCARAMUZZINO AND BRIGITTE SUTER

12 Community-based sponsorship of refugees resettling in the UK: British values in action? JOANNE VAN SELM

13 Crisis and Willkommenskultur: civil society volunteering for refugees in Germany THERESE HERRMANN

14 Cosmopolitanism at the crossroads: Swedish immigration policy after the 2015 refugee crisis CHRISTIAN FERNÁNDEZ

15 (Un)Deserving refugees: contested access to the 'community of value' in Italy

CHIARA MARCHETTI

16 Christian charity as the last line of defense for migrants in Ventimiglia

JUAN PABLO ARIS ESCARCENA

17 Proclaiming and practicing pro-immigration values in Poland: a case study of Poznań

IZABELLA MAIN

18 Concluding thoughts

ELŻBIETA M. GOŹDZIAK, AND BRIGITTE SUTER

Index 


\section{Illustrations}

\section{Figures}

4.1 Countries with increasing levels of Rejection Index between 2002 and 2016, European Social Survey, percentage of 15+ population

4.2 The pressings of the Moral Panic Button (2015-2019)

4.3 The level of popularity of FIDESZ (proportion of potential voters among those entitled to vote) 2014-2019

4.4 The prevalence of the perception of immigration, terrorism, and the loss of national sovereignty as the main threats for Hungary, 2017-2018, percentage of the total of selected items

4.5 The extent to which respondents hold international actors responsible for the main threats for Hungary, 2017-2018, percentage of the total of selected items

4.6 Perceived threats and the actors/groups held as responsible by political affiliation. Percentage of those who mentioned external threats (immigration and terrorism and losing national sovereignty) or threats of the ruling elite (state level corruption, demolition of democratic institutions), 2018

4.7 Rejection Index by demographic groups in four countries in 2016/2017

6.1 Number of work permits and declarations on entrusting work to a foreigner, issued between 2003 and 2018

6.2 Number of foreigners, who apply for international protection and who were granted any form of international protection in Poland 1992-2018

10.1 Main semantic fields in Parisian speeches about migrants' reception

10.2 Main semantic fields in Barcelona's speeches about migrants' reception

11.1 Number of residence permits issued in Sweden by category of immigration, 2009-2018 


\section{viii Illustrations}

\section{Tables}

7.1 Selected values and definitions from the value categories 'political interests,' 'respect for (fundamental) rights,' and 'democratic principles'

7.2 Value agents shaping the debate about deportation detention

9.1 Correlation between participation, tokenism, co-creation, and participatory spaces

11.1 Selected legislative drafts in the policy fields of migration and integration, before and after 2015

Box

4.1 Three questions from Hungary's 'National Consultation on Immigration and Terrorism' 


\section{Acknowledgements}

This volume would not have been possible without the support and collaboration of great many people. Our heartfelt appreciation goes to the authors who have contributed their thinking and research on norms and values in the context of the ongoing 'refugee crisis' to make this book a reality. Many are our colleagues on the NoVaMigra: Norms and Values in the European Migration and Refugee Crisis project, others are long-time collaborators, and still others newly met scholars. It has been a pleasure working with each and every one of them.

We are particularly grateful to Helena Hurd and Leila Walker at Routledge for their enthusiastic support of this project. We are also thankful to the anonymous reviewers who critically evaluated our book proposal and provided invaluable advice to strengthen the volume.

We are deeply indebted to C. Timothy McKeown, Zuzanna KrukBuchowska, Kosma Lechowicz, Emilia Bebic, Annika Otto, and Franziska Böhm for their editorial assistance. Without their exceptional command of the English language, attention to detail, and good humor, the task of copy editing and formatting this volume would have been daunting indeed.

And, last but not least, we would like to extend our appreciation to Andreas Niederberger for his continued support of the NoVaMigra team. We value your leadership.

We also want to thank each other! The distance between the far-flung cities where we were editing this volume notwithstanding, the production of this volume was an intimate intellectual endeavor and a rewarding experience.

Finally, we want to express our admiration for all the refugees seeking safe haven in Europe. We recognize your suffering and appreciate your contributions to the tapestry of European societies.

Generous support for this project was provided by the European Union's Horizon 2020 Research and Innovation Program under grant agreement No. 770330. We appreciate the European taxpayers' contributions. 


\section{Contributors}

Marilena Anastasopoulou is a research associate at the South East European Studies at Oxford (SEESOX), an Onassis Foundation Scholar, and a DPhil student in the Faculty of History at the University of Oxford. She holds a MSc degree in Migration Studies from the University of Oxford and a bachelor's degree in Political Science and Public Administration from the University of Athens, from which she graduated as the valedictorian. She has worked as a researcher at the Department of Politics and International Relations (DPIR), University of Oxford, at the Hellenic Foundation for European and Foreign Policy (ELIAMEP), and at the Hellenic Ministry of Foreign Affairs.

Juan Pablo Aris Escarcena is a PhD candidate at the University of Seville, engaged as researcher FPU ('Formación de Profesorado Universitario' Ministry of Education of Spain). He is part of GEISA Research Group (Group for the Study of Sociocultural Identities in Andalusia). His doctoral research focuses on the legal and bureaucratic practice of EU member states in border zones. He has developed a multi-sited ethnographic research through several borderland locations in Europe: Ceuta, Melilla, Katsikas, Calais, Ventimiglia, Calabria, and Palermo. He has also been visiting scholar at CONICET, Argentina and Universidad Autónoma de Coahuila, México.

Felix Bender is a researcher at Central European University (CEU), investigating the origins and patterns of displacement. He is particularly interested in the normative aspects of refugee movements and the theoretical origins of refugee status determination. He has held Visiting Positions at the Refugee Studies Centre at the University of Oxford, the University of Amsterdam, and the Woodrow Wilson Center for International Scholars in Washington, DC.

Christian Fernández is associate professor of political science at the Department of Global Political Studies, Malmö University, and senior researcher at the Malmö Institute for Studies of Migration, Diversity and Welfare. His main research interests are political theory and citizenship, 
integration, toleration, freedom of speech, and education. His latest publications include articles on immigrant integration in Sweden and Denmark, and a monograph on free speech and political correctness.

Márton Gerő is a research fellow at the MTA Centre for Social Sciences in Budapest, Hungary. He teaches sociology at the Eötvös Loránd University, Faculty of Social Sciences and his research interests include civil society, social integration, and the use of enemy images in politics.

Halleh Ghorashi is Full Professor of Diversity and Integration in the Department of Sociology at the VU (Vrije Universiteit) Amsterdam, the Netherlands. She is the author and co-author of several books and has published many articles on topics such as identity, diasporic positioning, and cultural diversity both inside and outside organizations. Her most recent book publication is the edited volume Contested Belonging: Spaces, Practices, Biographies (Emerald 2018; with K. Davis \& P. Smets). In 2018, she was appointed as a Crown Member of the SER (Dutch Social Economic Council).

Elżbieta M. Goździak is both a migration scholar and a forced migrant. Currently, she is a Visiting Professor at the Adam Mickiewicz University in Poznan and a Research Professor at OsloMet University in Norway. In 2016, she served as the George Soros Visiting Chair in Public Policy at the Central European University in Budapest, Hungary. She served as Editor of International Migration, held a senior position in the Office of Refugee Resettlement (ORR), taught at Howard University, and conducted research for the Refugee Policy Group. Her recent books include Children and Adolescents Trafficked to the United States: Reimagining Survivors (Rutgers 2016); Contested Childhoods: Growing up in Migrancy (Springer 2016; with Marie Louise Seeberg); Migrant Children: At the Crossroads of Vulnerability and Resiliency (Palgrave 2010) and Children and Forced Migration. Durable Solutions During Transient Years (Palgrave 2017), both with Marisa O. Ensor.

Johanna C. Günther is a PhD candidate in political science at the FriedrichAlexander-University Erlangen-Nuremberg, Germany. She has completed a Master's program in European studies at Freie University Berlin. Her research focuses on the nexus of legal and political aspects of European and German asylum policies. She was a researcher at Freie University's Institute for European Integration and a project assistant at the European Network of National Human Rights Institutions. Beyond her academic work she reported on aspects of asylum policy for the German Institute for Human Rights, the German International Corporation for Development, and the Robert Bosch Foundation.

Myriam Hachimi Alaoui is Associate Professor at the University Le Havre Normandie with a specialization in sociology of citizenship, immigration, and nationality. She is also CI Migration fellow (2018-2021) of the French 


\section{xii Contributors}

Collaborative Institute on Migration. Her current research focuses on the sense of national belonging in France and French overseas (Mayotte) that she investigates from both an institutional and biographical approach. Her articles on these topics appeared in a series of edited volumes and journals such as Ethnologie française (2018), Politics (2016), Canadian Journal of Women and the Law (2012).

Therese Herrmann is a Research Associate at the University of Essen, where she works on a $\mathrm{PhD}$ on transnational democracy and European migration law. She is also a consortium member in the EU-funded research project Norms and Values in the European Migration and Refugee Crisis (NoVaMigra).

Louise Hombert is a doctoral student in Political Science at Paris Dauphine University-PSL Research University, and a fellow of the Institut Convergences Migrations (2018-2021). Her work focuses on 'refuge-cities' and their governance of solidarity, including NGOs and citizen collectives' influences in the construction of local welcoming policies. For her doctorate, she is conducting a comparative analysis of Paris and Barcelona's situations, regarding the European reception 'crisis.' Her research also leads her to study city-to-city dynamics, including city networks specialized in migration issues.

Witold Klaus is a lawyer, criminologist, and migration scholar. He is a professor in the Institute of Law Studies at the Polish Academy of Sciences and a researcher in the Centre of Migration Research at the University of Warsaw. He was one of the founders and currently serves as the member of the Board of the Association for Legal Intervention, one of the leading NGOs assisting migrants in integration processes in Poland. He was an advisor to the President of Poland and Polish Ombudsperson, and was awarded scholarships from the British Academy and Max Planck Society.

Robert Larruina (MSc) is a $\mathrm{PhD}$ candidate and teacher in the Department of Organization Sciences at VU (Vrije Universiteit) Amsterdam, the Netherlands. His research is affiliated with the university's Refugee Academy (Institute for Societal Resilience). Since 2011, he has been studying refugee reception and integration in the Netherlands and the role that (emergent and established) civil society, governmental, and refugee-led organizations play in these processes. Currently, he is focusing on multi-stakeholder collaboration and co-creation processes in refugee policymaking and entrepreneurship.

Izabella Main is associate professor at the Department of Ethnology and Cultural Anthropology at the Adam Mickiewicz University in Poznań and Deputy Director of the Center for Migration Studies. Her interests include anthropology of migration, medical anthropology, and studies on memory. In the Center for Migration Studies, she conducts research in 
the Horizon 2020 project on Norms and Values in the European Migration and Refugee Crisis (NoVaMigra) with a particular emphasis on civil society's activities. She has recently initiated and co-organized educational and training projects: Who asks, does not err. Let's talk about refugees and Workshops on migrants and refugees.

Chiara Marchetti, professor of Sociology of Intercultural Relations at the University of Milan, Italy, is among the founders of the Coordinated Research Center Escapes Laboratorio di studi critici sulle migrazioni forzate. Her research activities focus on international migration, with particular attention to asylum, forced migration, and the role of the third sector in the integration of asylum seekers and refugees.

Bernard Mossé is head of research, training, and education at the Foundation Camp des Milles - Mémoire et Education, France. He is the coordinator of the UNESCO Chair 'Education for Citizenship, Human Sciences, and Convergence of Memories' directed by Aix-Marseille University (AMU) and the Foundation. At AMU, he is also member of the Steering Committee for Gender Equality and Against Discrimination. A historian by training, he has long been a trainer at the National Education Department.

Janie Pélabay is FNSP tenured Research Fellow at Sciences Po, Centre for Political Research (CEVIPOF), CNRS (UMR 7048). In the field of political philosophy, she investigates the theoretical and practical challenges posed by pluralism to liberal democracy and the contemporary debates on state neutrality, multiculturalism, and patriotism. Her current research focuses on the political uses of 'shared values' in public discourses and policies related to civic education, immigration, and European integration. Her recent publications include an article on citizenship revocation (co-authored with R. Sénac) in Citizenship Studies (2019) and a paper on communitarian equality in International Social Science Journal (2017).

Roberto Scaramuzzino is an associate professor at the School of Social Work at Lund University in Sweden. His research interests include changes in the welfare and integration systems and the role of civil society organizations from a cross-national comparative perspective. He has been engaged in studies of civil society actors' mobilization, advocacy activities, and collaboration with public authorities. He has also conducted studies on the Europeanization of Swedish civil society. He is currently working in a research program on civil society elites focusing on leaders and power concentration in civil society in England, Italy, Poland, Sweden, and at EU level.

Joanne van Selm is an Independent Consultant on Migration and Refugee Policy Issues, currently based in Washington DC, following years spent in Kingston, Jamaica and Skopje, Northern Macedonia. She has global range 
on both protection and migration issues and has written on migration issues in Europe, the Caribbean, and North America, as well as international and regional institutional policy issues. Recent clients include the UK Home Office, European Commission, UNHCR, and IOM. Dr van Selm co-edited the Journal of Refugee Studies, Oxford University Press from 2001-2011 and was previously an adjunct professor at Georgetown University (2012-2013); Senior Policy Analyst at the Washington DCbased Migration Policy Institute (2001-2006), and Lecturer in Political Science at the University of Amsterdam and the Vrij Universiteit, Amsterdam. The author of several books and numerous chapters, and articles, Joanne van Selm has lived and worked in Japan, and several EU Member States.

Endre Sik is a researcher at the Institute for Sociology, at the Hungarian Academy of Sciences and professor emeritus at the Eötvös Loránd University of Budapest. His major research fields are the labour market, migration, informal economy, network capital, border studies, and discrimination.

Brigitte Suter is senior researcher and lecturer in International Migration and Ethnic Relations at the Malmö Institute for Studies of Migration, Diversity and Welfare (MIM) at Malmö University in Sweden. Her research interests include (im)mobility, social networks, the transformative potential of migration, ethnography, the mobility of highly skilled migrants in the global economy, as well as the role of norms and values in the field of migration and integration. She is currently part of the Horizon2020 founded research project on Norms and Values in the European Refugee and Migration Crisis (NoVaMigra), conducting fieldwork on value transmission in Sweden and Germany. 


\title{
1 European norms and values and the refugee crisis
}

\author{
Issues and challenges
}

Elżbieta M. Goździak, and Izabella Main

Deaths and suffering of migrants trying to enter Europe have become one of the defining moral and political issues of our time. Many humanitarian organizations and refugee advocates argue that these deaths result from Europe's policy of exclusion and closure. Others, especially those who claim that asylum seekers, particularly Muslims, constitute a threat to 'European values' call for even stricter border controls to resolve the 'refugee crisis.'

\section{Contesting the crisis narrative}

Is it a crisis? What kind of a crisis? It certainly does not seem to be a 'refugee' crisis, because the people fleeing armed conflicts and prosecution are not the problem. Catherine Woollard, the Secretary General of the European Council on Refugees and Exiles (ECRE), posits that what is often called 'the refugee crisis' is in fact 'a deep European political crisis which unrolled in 2015/2016, paralyzing decision-making and creating deep, probably irreparable, divisions between EU Member States' (Woollard 2018: 150).

There is no denying that large numbers of asylum seekers and migrants reached Europe in recent years. According to the UN High Commissioner for Refugees (UNHCR), 34,196 refugees have risked their lives reaching Europe by sea in the first half of 2019. In previous years the numbers were much higher. In 2017, over 105,000 refugees and migrants entered Europe. In 2016, an estimated 362,000 refugees and migrants risked their lives crossing the Mediterranean Sea, with 181,400 people arriving in Italy, and 173,450 in Greece. The highest number of arrivals - 1,015,078 - was recorded in 2015. More than 800,000 of them were smuggled by sea from Turkey to Greece, and the majority continued to travel through Europe to reach Germany and Sweden. ${ }^{1}$

These are indeed large numbers, but do they constitute a 'crisis'? Today's exodus from the Middle East pales in comparison with the situation Germany faced, and surmounted, after World War II. At the end of WWII, there were some 11 million displaced people in Germany alone. They were slave laborers, prisoners of war, and Holocaust survivors. The Germans who had lived in Eastern Europe were being expelled from Czechoslovakia, 
Poland, and Hungary. The arrival of several million newcomers in Europe in recent years presents real challenges, of course, but a prosperous European Union with a population in excess of 500 million has the means to overcome them, doesn't it?

There are also those who perished in trying to reach Europe by sea. Who could forget the small, lifeless body of three-year-old Syrian toddler Alan Kurdi found on a Turkish beach in September 2015? Although the number of arrivals in Europe has drastically decreased since Alan's death, people continue to attempt the journey, and many have lost their lives in the process. According to the International Organization for Migration (IOM), between the beginning of 2014 through August 2019, close to 19,000 migrants have died trying to cross the Mediterranean and reach Europe. ${ }^{2}$ The death of each and every one of those who perished is a crisis for their loved ones, but it is also a crisis of values as governments continue to criminalize the rescue operations (HRAS 2019). As we write this introduction in August 2019, 507 migrants and refugees are stranded on two rescue vessels, which picked them up of off the coast of Libya. The UN's Refugee Agency (UNHCR) made an urgent appeal for the refugees to be allowed to disembark, calling it a 'race against time' as bad weather approaches (Squires 2019). While some are trying to rescue refugees to avert a true crisis, others continue to propagate the crisis narrative.

Reinhart Koselleck (2006) shows how 'crisis,' a concept which the Greeks used to delineate stark alternatives - right or wrong, salvation or damnation, life or death - has constantly framed modern ideas of history. Migration scholars, however, argue that face-value acceptance of crisis narratives related to recent flight of asylum seekers to Europe results in viewing and managing migration according to binary divisions: integration versus segregation, modernity versus cultural backwardness, the deserving versus the undeserving, and through the manufactured dichotomy between refugees and economic migrants (Crawley \& Skleparis 2018; McMahon \& Sigona 2018).

Cautionary lectures by migration scholars notwithstanding, politicians have certainly been exploiting the powerful narrative of 'crisis' as a political tactic. Sebastian Kurz, the Federal Chancellor of Austria and a rising star of Europe's center right, in an article published in Time magazine in 2017, invoked 'crisis' multiple times. He paired the term with phrases such as 'loss of control,' 'overwhelmed by developments,' 'a huge challenge for our country,' 'regain control,' and 'find solutions' (Kurz 2017). For Sebastian Kurz, "the "migration and refugee crisis" was not just an objective state of affairs: it was also a political tactic to present himself to a global Anglophone readership as a firm but measured state leader' (Dines et al. 2018: 440).

Viktor Orbán, the Prime Minister of Hungary, has exploited the crisis narrative to defend his draconian measures aimed not only at barring refugees from Hungary, but also at criminalizing assistance to refugees and migrants. When some 400,000, mainly Muslim, refugees and asylum-seekers crossed the Serbian-Hungarian border, and descended on the Keleti Railway 
Station in Budapest in 2015, Viktor Orbán did not see the refugees fleeing war-torn countries as a humanitarian challenge but as a Muslim invasion that required an appropriate response: closing the Balkan land route to the European Union (Goździak \& Márton 2018), and pressing the 'moral panic button' (Gerő \& Sik, this volume). His friend, Jarosław Kaczyński, the president of the Law and Justice party in Poland, has also been making the most of the crisis narrative despite the fact that, with the exception of some Chechens, there are virtually no refugees in Poland (Klaus, this volume).

Both Orbán and Kaczyński use the crisis narrative to talk about the threat that Muslim refugees pose to the Christian identity of Europe and call for protection of 'European values.' The Hungarian media likened the current 'migration crisis' to the Ottoman era "when Hungary was a "bastion," defending Christianity from "Muslim hordes"” (Pall \& Sayfo 2016: 6). Antal Rogán, at the time leader of the Hungarian Fidesz' parliamentary group, warned of a future 'United European Caliphate' (Villányi 2015), while former Secretary of State László L. Simon urged Hungarians to make more babies in order to counter the negative cultural effects of mass migration such as the envisioned 'impending victory of Islamic parties imposing polygamy and destroying the remainder of European culture' (Simon 2015: 231). These political statements have been used to strengthen the discourse about Christian identity of Europe and to portray refugees as terrorists despite the fact that neither Hungary nor Poland have ever experienced a terrorist attack, and those that launched terrorist attacks on different European cities were born in Europe. However, as Hasan (2012: 61) argues, 'propaganda against Islam and Muslims is nothing new in the West. [...] Europeans always constructed Islam as a civilizational adversary and the religion, an antithesis of European values.'

\section{What are 'European values'?}

There are multiple interpretations of 'European values.' The expression is often subject to different uses and misuses, by individuals, and institutions. The European Union and its member states refer to the EU Treaties, with the clearest expression of values in Article 2 of the Treaty of the European Union (TEU). Article 2 states: 'The EU is founded on the values of respect for human dignity, freedom, democracy, equality, the rule of law, and respect for human rights, including the rights of persons belonging to minorities' (TEU). These quintessentially democratic values are shared by other democracies outside the European Union, and outside the European continent - countries like New Zealand, and Canada come immediately to mind - therefore calling them 'European values' seems a little presumptuous.

Recently, 'European values' have been invoked both to support refugees and migrants and to attack them. On one hand, demagogues such as Viktor Orbán have positioned themselves as defenders of a Christian Europe, and enacted anti-migrant policies to protect Europe from being overrun by 
Muslims. On the other hand, humanitarians often appeal to a vision of Europe 'As a community of nations that has overcome war and fought totalitarianism' (Barroso 2012). In his acceptance speech of the Nobel Peace Prize on behalf of the EU in 2012, José Manuel Barroso (2012), President of the European Commission, assured his audience that the European community 'will always stand by those who are in pursuit of peace and human dignity.'

Daniel Trilling (2018) asserts that the visions of Europe promulgated by Orbán and Barroso are wrong. Orbán's rendition omits the fact that Europe is a diverse continent, in which Christian, Muslim, Jewish, and secular traditions have been present for centuries. Orbán's vision also claims that refugees and asylum seekers present a threat to 'European' traditions of tolerance, freedom, and democracy. History reminds us that these principles have been fought for and won, usually against the violent resistance of European elites. Ironically, many of the refugees seeking safe haven in Europe have struggled for the same values and rights in their home countries.

The vision endorsed by humanitarians such as Barroso presents Europe as a beacon of hope to the rest of the world. Trilling (2018) argues that Europe is in the position to affect the world for better or worse and pressing politicians to live up to such an ideal is certainly worthwhile. However, he further argues:

The aspiration will remain unfulfilled if we ignore the fact that while the nations of Europe have overcome war and fought totalitarianism, many of these same nations became rich and powerful by conquering and administering huge empires, which were partially justified by the idea of European racial supremacy. And European unity, in its founding documents, was conceived of as a way of maintaining imperial power, as well as preventing future conflict in Europe.

(Ibid. 2018)

Let's not forget the history of Europe. Let's also remember that European racism is not a thing of the past and that Europeans need continued education about racism, and skills to fight it (see Mosse, this volume).

\section{Which values are at risk?}

Taking stock of the actions implemented to solve the Mediterranean crises and the wider European political crisis on migrant and refugee protection, Catherine Woollard (2018) concludes that the solutions seriously undermined Europe's values, both directly and indirectly. 'Human dignity is clearly absent in the conditions in which refugees and migrants find themselves in Europe and in the countries in which they are stuck as a result of European action,' she writes (Woollard 2018: 151). In this volume, several 
authors provide examples of lack of respect for human dignity. In Ventimiglia, local politicians on both sides of the Italian-French border, have created a hostile environment, where the presence of migrants was not welcomed and attempts were made to encourage the disappearance of migrants from the area by denying them housing spaces, prohibiting food distribution, and expelling them from the territory of the city (Aris Escarcena, this volume). In Germany, the Willkommenskultur approach to refugees early on (Hermann, this volume) has shifted and detentions and deportations have increased resulting in a polarized nation fearful that more migration will lead to a greater divide in society (Günther, this volume).

Human dignity is also undermined in the ways refugees and migrants are portrayed by the media, and by politicians. Migration is often discussed in military terms - words and phrases such as invasion, threat, defense of borders - are used along with either openly or insidiously racist or Islamophobic commentaries. Framing the current 'refugee crisis' as a security threat is part of a broader and older attempt to portray migration across international borders as a security risk. Once it was announced that the nineteen hijackers, who attacked the Twin Towers in New York City, the Pentagon in Washington, DC, and crashed a plane in Shanksville, Pennsylvania, were foreign nationals, those critical of the U.S. immigration system argued that the government must use all available means to protect the national security of the country. The critics called for 'enhancing and enlarging the border security functions of the Immigration and Naturalization Service (INS)' (Chebel d'Appollonia 2012: 1). Within a few days, the Immigration and Nationality Act was adopted, and a series of reforms aimed at implementing immigration restrictions, including detention of foreign-born individuals without charge, began.

Terrorist attacks in Paris, Brussels, and Niece have sparked similar assertions in Europe despite the fact that the terrorists were French and Belgian citizens. Facts notwithstanding, policy-makers on both sides of the Atlantic allege that human smuggling and human trafficking are a conduit for international terrorism. On September 20, 2001, the Council of the European Union called for strengthening of surveillance measures, including vigilance in issuing residency permits, and systematic checking of identity papers, under article 2.3 of the Schengen Convention. The bombings of Madrid on March 11, 2004 and London on July 7, 2005 further consolidated the national security policies in Europe.

However, these anti-immigrant sentiments and conceptualizations of migrants as criminals and terrorists predate the terrorist attacks by at least a decade or more. In the 1990s, conservative discourses identified multiculturalism as a cause of societal disintegration. The best-known version of this kind of discourse is Huntington's The Clash of Civilizations (1996). It mediates the differentiation between us and them by identifying other peoples and cultures that endanger the survival of the home culture. Migration is identified as being one of the main elements weakening national tradition 
and threatening societal homogeneity. The current debates in Europe (and elsewhere) also contribute to 'othering' refugees and migrants, which is another way to strip people of their dignity.

The human rights that are not respected start with the most basic and most important right: the right to life, which is undermined by the ceasing and disruption of search and rescue missions, and criminalization of assistance to asylum seekers. As Aris Escarcena writes in this volume, in extreme cases, such as that of Cedric Herrou, a French farmer who provided support to migrants in the border area between France and Italy, volunteers were convicted for 'crimes of solidarity' (Tazzioli \& Walters 2019). Carola Rackete, the German captain of a humanitarian rescue ship with 40 migrants aboard, was arrested in June 2019, after she rammed her vessel into an Italian border police motorboat while docking at a tiny Mediterranean island in defiance of Italy's anti-migrant interior minister, Mateo Salvini. German Foreign Minister Heiko Maas criticized the Italian decision to arrest the captain. 'Saving lives is a humanitarian duty,' he said on Twitter. 'Rescue at sea must not be criminalized. It's up to the Italian justice system to swiftly resolve the allegations' (D’Emilio \& Jordans 2019).

Other freedoms are also being undermined. Freedom from torture is violated by the containment of people in Libya, where the horrific conditions are well known (Dambach 2019). The right to asylum in Europe is in danger; asylum seekers often cannot reach the European Union or are prevented from submitting asylum claims (Pech et al. 2018; Klaus, this volume). However, one of the greatest challenges facing policy-makers in Europe concerns the rule of law. The rule of law has been deteriorating in some European countries, with Hungary and Poland as the biggest offenders, and the four Visegrad countries refusing to participate in the relocations scheme (EC 2018).

It is obvious that the European Union will not be able to function properly without some level of solidarity between and among member states. As Catherine Woollard (2018: 156) wrote:

The idea of the EU as a normative power is being undermined. The idea of normative power is either that the EU is a model which others follow through choice rather than through the use of force, or that it is a promoter of its values in the world, gaining credibility through the implementation of those values in its own territory. In either sense, the crisis on the migration and refugee issue has damaged normative power.

\section{The contributions}

It is against these issues and challenges that the project on Norms and Values in the European Migration and Refugee Crisis (NoVaMigra) has been undertaken by eight universities in eight different countries: France, Germany, Greece, Hungary, Italy, the Netherlands, Poland, and Sweden. The present 
volume is the first product of the research we are conducting aimed at general readership, not just policy-makers in Brussels.

The contributors look at existing challenges and solutions for seamless integration of refugees, asylum seekers, and migrants in the eight countries. They discuss both European and national values and analyze activities undertaken by national and local actors. The volume is divided into four distinct but inter-related thematic strands that address and reflect upon different aspects of the migration crisis and values nexus.

The first strand considers the effects of xenophobia and racisms on attitudes towards refugees and the resulting moral panic. These anti-values are contrasted with the role of historical memory of forced displacement in forming contemporary attitudes towards migrants. In her paper based on oral testimonies collected from inhabitants of the Greek island of Lesvos, Marilena Anastasopoulou unpacks the fluid relationship between history, memory, identity, and values and the way they inform assistance to migrants and refugees today. Bernard Mossé also draws on history, this time the history of the Holocaust. Using the Foundation of the Camp des Milles in France, a memorial site for a camp used for interments and deportations from September 1939 to 1942 , as a case study, he describes the experiences of defending democratic values through educational and training programs for French citizens and visitors to the camp focused on racism and xenophobia, the promotion of hospitality to, and solidarity with refugees. This is a valuable contribution to the volume from a practitioner's point of view. Deploying the theoretical framework of the moral panic developed by Stanley Cohen (1972), Márton Gerő and Endre Sik analyze the construction of the moral panic button in Hungary to portray refugees and immigrants as a threat to the European values.

The second theme coalesces around restricting access to the European continent by erecting barbed wire fences, detaining asylum seekers, and deporting not just irregular migrants, but also those seeking safe haven. Writing about the abuse of human rights and the de facto abolition of the institution of asylum in Hungary, Felix Bender asks why there is little resistance to this situation by states that seemingly cherish the normative principle underlying the right to seek asylum. Bender argues that core EU states profit from the fact that countries at the EU periphery, such as Hungary, are keeping refugees at bay. He provocatively contends that this 'division of labor' allows Hungarian politicians to reap the political fruits of demonizing refugees, while simultaneously enabling core EU states, such as Germany, to foster the image of states upholding the right to asylum. Witold Klaus deconstructs the values underpinning Polish migration policy by analyzing legal and bureaucratic activities undertaken by Polish authorities after 2015. He juxtaposes the policies that focus on securitizing migration and closing borders to refugees, while at the same time accepting large numbers of Ukrainian labor migrants. Analyzing portraits of deportation detention in the German media, Johanna C. Günther maps out the values, actors, and their actions that shape German asylum policy. 
The analysis shows a shift in the socio-political climate in Germany: from a country that welcomed refugees to a highly polarized nation fearful that more migration will lead to a greater divide in society.

The third topic focuses on the role national and municipal governments play in the integration of refugees in France, Germany, the Netherlands, Spain, Sweden, and the United Kingdom. The cities of Paris and Barcelona serve as case studies interrogating policies and actions at the local level. In the opening chapter, Myriam Hachimi Alaoui \& Janie Pélabay analyze integration contracts, Contrat d'Accueil et d'Intégration and the Contrat d'Intégration pour la Famille, aimed at ensuring public promotion of the 'values of the Republic' among newcomers eligible for residence permits, whether they be migrants or refugees. These programs are part and parcel of the 'civic turn' (Mouritsen \& Jørgensen 2008) in immigration and integration policies implemented in a variety of European countries starting in the late 1990s. Their analysis is based on field research in Paris and Lille conducted between 2012 and 2015. Robert Larruina and Halleh Ghorashi also use empirical research to investigate the role of migrants and refugees in the European Migrant Advisory Board (EMAB). This chapter builds on their previously published studies (Ghorashi 2010; Larruina, Boersma, \& Ponzoni 2019) and asks a very important question: What are the challenges and opportunities of including refugees' perspectives in EU policy? Comparing Paris and Barcelona, Louise Hombert takes a close look at the rhetoric the mayors of these cities have mobilized to talk about reception of migrants. Both metropoles call themselves 'refuge cities,' but given their very different migration situations and political contexts, Hombert asks whether being a 'refuge city' has the same meaning and the same stakes for both Paris and Barcelona. Roberto Scaramuzzino and Brigitte Suter spotlight Swedish community-based organizations (CBOs) that have been very active during the 'refugee crisis' of 2015 and discuss their value-based advocacy aimed at affecting migration policy-making in Sweden. As Brexit hangs in the balance and the politics spiral out of control in the United Kingdom, Joanne van Selm looks at community-based sponsorship for refugees. Her chapter tries to answer the following core questions: how can we conceptualize participation in community sponsorship efforts from a values perspective? How could sponsorship of refugees by a few spread those values to, or strengthen those values in others in society? How can tolerance be understood, and developed, in a country where immigration has happened more quickly than its core citizenry has managed to adapt to it? In her chapter, Therese Hermann, looks at the mobilization of large-scale support for incoming refugees within the framework of Willkommenskultur. She argues that the volunteers' focus on diversity and sustaining local networks are better understood within a framework of care ethics, rather than humanitarianism.

The final thematic strand centers on practicing pro-migration values in different national and local contexts. Christian Fernández opens the fourth part of the book by looking at Swedish cosmopolitanism and the evolution of the country's immigration policy in the post-2015 period. He wonders 
what the changes in the immigration policy mean and asks whether we are witnessing the break-up of the Swedish model of immigration. Turning her attention to Italy, Chiara Marchetti asks: what happens when a regime of rights is substituted by a regime of deservingness? What do Italian institutions expect from migrants, and vice versa? How do social workers mediate these possibly conflicting expectations? She examines how asylum seekers and social workers struggle for recognition as the way to deal with Others at the nexus where models based on rights, deservingness, and control operate, and where 'refugees' are more and more considered to be 'irregular economic migrants' and must increasingly demonstrate that they are not. Juan Pablo Aris Escarcena takes us to Ventimiglia, the Italian coastal town closest to France. The border between Italy and France has become a hostile environment, a result of political measures of both states. Using his ethnographic research in Ventimiglia, Escarcena analyzes how the local Catholic parish supported mobilization of volunteers by appealing to fundamental values of civil society in the town where refugees gathered in the hope of getting access to France. In the final chapter of this section, Izabella Main takes a look at Poznań, a city in Western Poland, to juxtapose the anti-refugee narrative promulgated by the current Law and Justice government in Poland with policies and practices, underscored by pro-immigration values, at the local level. The activists she interviewed to inform this chapter had two goals: 1) to support refugees and migrants (in Poland and abroad) and 2) to educate and mobilize Polish society to counterbalance negative discourse supported by the government and state media. The result of the first was, as she points out, a proverbial 'drop in the bucket.' Assessing the outcomes of actions aimed at social change is methodologically and epistemologically difficult, and requires a long-term perspective.

The volume ends with short Conclusions where Elżbieta M. Goździak and Brigitte Suter identify possible solutions and improvements needed to step away from the crisis narrative in order to facilitate lasting integration of different types of migrants.

\section{Notes}

1 See UNHCR website www.unhcr.org/europe-emergency.html

2 See IOM Missing Migrants Project website https:/missingmigrants.iom.int/

\section{References}

Barroso, J. M. (2012). Nobel Peace Prize Speech. Available at: https:/europa.eu/ rapid/press-release_SPEECH-12-930_en.htm

Chebel d'Appollonia, A. (2012). Frontiers of Fear. Immigration and Insecurity in the United States and Europe. Ithaca: Cornell University Press.

Cohen, S. (1972). Folk Devils and Moral Panics. London: MacGibbon \& Kee. 
Crawley, H. \& Skleparis, D. (2018). 'Refugees, migrants, neither, both: Categorical fetishism and the politics of bounding in Europe's "migration crisis," Journal of Ethnic and Migration Studies 44(1), pp. 48-64.

Dambach, K. (2019). 'New images of tortured migrants emerge from Libya,' InfoMigrants, 1 March. Available at: www.infomigrants.net/en/post/15467/new-images-of-tortured-m igrants-emerge-from-libya

D'Emilio, F. \& Jordans, F. (2019). 'Migrant aid ship captain arrested after ramming italian police boat,' Huffington Post, 29 June. Available at: www.huffpost.com/entry/ italian-aid-migrant-ship-captain-arrested_n_5d1825dce4b082e5536a6f08

Dines, N., Montagna, N., \& Vacchelli, E. (2018). 'Beyond crisis talk: Interrogating migration and crises in Europe,' Sociology 52(3), pp. 439-447.

EC (European Commission) (2018). Relocation: Commission Launches Infringement Procedures against the Czech Republic, Hungary and Poland. Available at: https:// europa.eu/rapid/press-release_IP-17-1607_en.htm

Ghorashi, H. (2010). 'The right to be different: The position of Muslim migrants in the Netherlands,' in Banakar, R. (ed.), Rights in Context: Law and Justice in Late Modern Society. Surrey: Ashgate, pp. 163-177.

Goździak, E. M. \& Márton, P. (2018). 'Where the wild things are: Fear of Islam and the anti-refugee rhetoric in Hungary and in Poland,' Central and Eastern European Migration Review 7(2), pp. 125-151.

Hasan M. (2012). 'Feminism as Islamophobia: A review of misogyny charges against Islam,' Intellectual Discourses 20(1), pp. 55-78.

Huntington, S. P. (1996). The Clash of Civilizations. Touchstone: New York.

HRAS (Human Rights at Sea) (2019). Briefing Note. Legal and Policy Matters arising from the Increased Criminalization of Civil Society Search and Rescue Activities in the Mediterranean. Available at: https:/safety4sea.com/wp-content/uploads/2019/02/ HRAS-Legal-and-Policy-Matters-Arising-from-the-Increased-Criminalisation-of-theCivil-Society-Search-and-Rescue-Activities-in-the-Mediterranean-2019_02.pdf

Koselleck, R. (2006). 'Crisis,' Journal of the History of Ideas 67(2), pp. 357-400.

Kurz, S. (2017). 'Only by regaining control can we solve the migration and refugee crisis,' Time, 18 December. Available at: http://time.com/5068561/sebastian-kurz-a ustria-chancellormigrant-crisis/

Larruina, R., Boersma, K., \& Ponzoni, E. (2019). 'Responding to the Dutch asylum crisis: Implications for collaborative work between civil society and governmental organizations,' Social Inclusion 7(2), pp. 53-63.

McMahon, S. \& Sigona, N. (2018). 'Navigating the Central Mediterranean in a Time of "Crisis": Disentangling Migration Governance and Migrant Journeys,' Sociology 52(3), pp. 497-514.

Mouritsen, P. \& Jørgensen, K. E. (eds) (2008). Constituting Communities. Political Solutions to Cultural Conflict. Basingstoke: Palgrave Macmillan.

Pall, Z. \& Sayfo, O. (2016). 'Why an Anti-Islam Campaign Has Taken Root in Hungary, a Country with Few Muslims,' Revue, 14. September. Available at: http://visegra drevue.eu/why-an-anti-islam-campaign-has-taken-root-in-hungary-a-coun try-with-few-muslims/

Pech, T., Tran Thiet, J.-P., \& Rial, J.-F. (2018). Saving the Right to Asylum. [Report]. Paris: Institut Montaigne. Available at: www.institutmontaigne.org/en/publications/ saving-right-asylum 
Simon, L. (2015). Szaporodjunk! Népszabadság. [Video]. 5 September. Available at: http:// nol.hu/video/lsimon-a-szaporodasban-latja-a-jovot-1573295?utm_source=mandiner\& utm_medium=link\&utm_campaign=mandiner_201601

Squires, N. (2019). 'UN urges Europe to allow 500 migrants stranded on rescue boats to be allowed to come ashore,' The Telegraph, 13 August. Available at: www.telegrap h.co.uk/news/2019/08/13/un-urges-europe-allow-500-migrants-stranded-rescue-boats-al lowed/

Tazzioli, M. \& Walters, W. (2019). 'Migration, solidarity and the limits of Europe,' Global Discourses 9(1), pp. 175-190.

TEU (Treaty of the European Union). Article 2. Available at: https:/eur-lex.europa. eu/legal-content/EN/TXT/?uri=celex $\% 3$ A12012M\%2FTXT

Trilling, D. (2018). Five myths about the refugee crisis. The Guardian, June 5. Available at: www.theguardian.com/news/2018/jun/05/five-myths-about-the-refugee-crisis

Villányi, K. (2015). Azt Akarjuk, Hogy Unokáink egy Európai Kalifátusban Éljenek? Magyar Idök, 14 November. Available at: http://magyaridok.hu/belfold/azt-akarju k-hogy-az-unokaink-egy-europai-kalifatusban-el-jenek-5035/

Woollard, C. (2018). Has the Mediterranean refugee crisis undermined European values? IEMed Mediterraneum Yearbook 2018, pp. 150-156. 


\title{
2 Echoes of memories of forced displacement
}

\author{
The case of the Greek island of Lesvos
}

\author{
Marilena Anastasopoulou
}

\section{Introduction}

How do people's memories of forced relocation affect their identities, values, and attitudes towards contemporary migrants and refugees? In this chapter, I examine the potential effects of refugee memory through the historical parallel between the Greek-Turkish population exchange (1923) and the contemporary migration and refugee flows (2015). More specifically, while focusing on the case of the Greek island of Lesvos, the question that I aim to address is: how do people with family memories of forced relocation relate to contemporary migrants and refugees? To unpack the fluid relationship between history, memory, identity, and values, as well as the way they inform assistance to migrants and refugees, I will use evidence drawn from primary sources, including oral testimonies from my fieldwork on Lesvos in the course of 2017, and archival evidence.

Lesvos is an island that constitutes an entry port for significant contemporary migration flows and whose present population composition has to a large degree been formed by the 1923 population exchange. In Greece, the case of Lesvos is far from rare given that a significant percentage of the country's current population is descended from refugees from Asia Minor (Tata Arsel 2014). Manifold examples illustrate that a large percentage of Greece's population has experienced immigration and forced displacement. The reason I chose to examine forced displacement memories in Greece through the case study of the Greek-Turkish population exchange can be summarized in the following points. First, this exchange of populations poses paramount international interest in modern history since "[i]t was the first time in history that the transfer of large ethnic groups was tried as a means to separate nationally intermingled people' (Pentzopoulos 1962: 18). In addition, it is central to the Greek identity dominating 'the modern Greek consciousness as the fundamental event which has transformed the form and the character of the contemporary history of the nation' (Kitromilides 1972: 372).

Although limited in scope, the present chapter has broader implications and is relevant to many countries with similar traumatic experiences of forced displacement. Forced displacement has been experienced by a large 
percentage of people throughout the world. By drawing boundaries within intermingled populations through forced assimilation, large-scale human displacement, ethnic cleansing, and mass killings, nation-states were built on 'victories as much as on defeats, on "catastrophes" and traumas' (Akgonul 2009: 195), shaping collective memories central to ethnic identities.

Europe's current demographic profile is rooted in past relocation experiences of forced displacement. Considering this, the rise of xenophobic sentiment, the great debates with regard to refugees' distribution within the European Union, and the place of the newcomers in the host societies (Gero $\&$ Sik 2019; Main in this volume), it comes into question how and to what extent memories of forced migration influence people's attitudes towards contemporary migrants and refugees. My aim is to examine the effects of the wounds of memories of forced displacement on people's identities, values, and attitudes towards subsequent migration in the context of Europe's 'migration crisis.'

\section{Narratives}

The data that inform this chapter ${ }^{1}$ derive from the collection of primary sources using oral testimonies from my fieldwork on the island of Lesvos in 2017 and archival evidence from the Oral History Tradition archive of the Centre of Asia Minor Studies. ${ }^{2}$ It should be noted that this research is not designed 'to tell a fully representative story - an unmanageable task for any project that adopts in-depth interviewing' (Gildea \& Mark 2013: 11) but rather to unpack histories of subjectivities, providing a more diversified picture.

This chapter aims to shed light on the interplay between the Asia Minor refugee memory of forced displacement and people's identities and values with regard to subsequent migration in the context of Europe's 'migration crisis.' With this aim, the case of Lesvos has been chosen based on the following criteria. Firstly, this island experienced the greatest number of refugee arrivals in both 1923 and 2015 relative to its size and constitutes the largest port of arrivals and a traditional epicenter of both the past and the contemporary refugee arrivals. A second criterion is the island's proximity and exposure to the contemporary migration due to the existence of refugee camps and other accommodation facilities.

My main analytical category is Asia Minor refugees and their descendants of the second and third generations. My sample also includes people without refugee family background. Using snowball sampling and access to refugee associations, I traced people with refugee roots. I conducted 13 face-to-face, in-depth, and semi-structured interviews on the island of Lesvos in Mytilene (the capital and port of the island), Moria (a hotspot), and Kara Tepe (a refugee camp).

Through the lens of micro-history, I carried out an in-depth analysis at the individual level and related it to collective and cultural frameworks of 
remembrance. The questions of what kind of memory is transmitted and if it is lasting or changeable over time, as well as its imprint on the transmitted identities and values was elucidated through the conducted interviews. Tracing voices that otherwise would have been lost, my analysis went beyond traumatic events as such, examining histories of subjectivities and 'the changing uses and meanings of that past in the present' (Thomson 2015: 26).

\section{A historical parallel}

At the end of World War I, 'the logic of European nationalism as it tried to rationalize the end of a multi-confessional empire' (Mazower 1998: 61) underlined the events following the defeat of the Greek army in Asia Minor in 1922. Specifically, under the Lausanne Convention of January 30, 1923, Greece and Turkey agreed on the compulsory exchange of populations of their respective religious minorities: Greek Orthodox Turkish nationals living in Turkish territory and Muslim Greek nationals living in Greek territory. One of the paradoxes of using religion as a marker of identification was that a significant percentage of the Orthodox population was Turkish-speaking (Kitromilides 2011). The influx of refugees ${ }^{3}$ expelled from Turkey to Greece was estimated at around 1.2 million people, while the number of Muslims expelled to Turkey from Greece was approximately 360,000 (Ladas 1932). As a result, during a period of war (19121922) and economic deprivation, Greece increased its population by 25 percent. It should be noted that enormous numbers of refugees had fled Asia Minor before the population exchange, primarily escaping to the island of Lesvos (Doumanis 2012).

After World War II came other phases of migration and forced displacement to Greece. Most significant, however, was the fact that in 2015, Greece, a country faced with a political and economic crisis, once again experienced the arrival of vast numbers of displaced people. The unfolding forced migration of refugees and their concentration along the Eastern Mediterranean, and Western Balkan route has challenged not only frontline Member States, but also the European Union's asylum and border policy as a whole. According to the United Nations Refugee Agency, during 2015 and early 2016 more than one million migrants and refugees arrived in Greece (UNHCR 2018). Most of these people fled from violence and war in countries such as Syria, Afghanistan, Iraq, Pakistan, and Somalia and reached Greece by crossing from Turkey to the Aegean islands, such as the island of Lesvos (Triandafyllidou 2015). Specifically, on Lesvos, where 'over 45 percent of the 770,838 refugees and migrants who arrived in Europe in 2015 have landed' (UNHCR 2015), a 'new humanitarian geography' was developed (Papataxiarchis 2016a: 12). This new geography is comprised of the Moria hotspot (identification center), established in October 2015, becoming the first operational hotspot in Greece and existing alongside other refugee camps. 
This historical parallel can be seen, more vividly, in the light of the following testimonies in which two refugees describe their dangerous journey to Greece:

In the boats, we suffered many hardships. The heat, the dirty, the overcrowded boat... We were getting sick and many people were dying. We tied a stone to their neck and we threw them into the sea.

(Kallistheni Kallidou 1923, cited in Mourelos 2014: 259)

The moment we went on the inflatable boat, we felt something was wrong, it was losing pressure ... we decided to jump in the sea and hold on to the boat on both sides ... a wave hit me on my face and the water went inside my lungs, and I started to cough.... That's the moment I lost the boat.

(Mohamed 2015, cited in Amnesty International 2015: 2)

\section{A historical account of the Greek-Turkish population exchange}

The Greek-Turkish population exchange resulted in many demographic, ethnological, settlement, economic, political, social, and cultural effects, whose impacts form the central analytical theme of the largest body of the existing literature. Although the present analysis takes into account both Greek and Turkish historiography, in this chapter emphasis is given to the impacts of this exchange in Greece.

On both sides of the Aegean, the 1923 events led to nearly complete national homogeneity. Specifically, the effective settlement of refugees under the Refugee Commission had a profound impact on the ethnic homogenization and consolidation of Greece. The Asia Minor refugees became 'the frontier population' (Pentzopoulos 1962: 139), safeguarding the country's territorial integrity. Although it is known that the refugees brought new skills and expertise, there is a debate regarding their economic role. As far as the emerging political patterns are concerned, Mavrogordatos (1983) emphasizes the inherited legacy of the traumatic events in Greek politics, linking refugees' political behavior to the rise of the Communist Party. The political and primarily economic problems led to contested social relations between the newcomers and the local population, enhancing prejudice and hostility. The refugees on both sides of the Aegean were often stigmatized by local Turks as 'half infidels,' 'infidel seeds,' 'fake Muslims/Turks,' or 'Muslims of Ali Pasha of Ioannina,' and by local Greeks as 'Turkish seeds,' 'baptized in yogurt' or 'Orientals' (Hirschon 2003). The preservation of a separate identity, on the side of the newcomers, hindered their integration.

This conscious maintenance of a separate Asia Minor identity and cultural distinctiveness has been further illuminated by anthropological insights. Specifically, through her ethnography of Kokkinia, which is an urban quarter of the port city of Piraeus, Hirschon underlines that Asia Minor refugees would say, "referring to themselves, "We are Mikrasiates" (Asia Minor 
people)' (1989: 4). Salamone's (1987) rural study focuses on the refugee heritage and the reconstruction of the Asia Minor home of refugee islanders established in a Greek fishing village called Amuliani. Analyzing the two studies, Loizos wondered 'at what point do the subjects stop being explainable primarily as refugees' (1999: 245).

Although the Greek-Turkish population exchange has attracted a great deal of attention, few scholars have thus far analyzed if and how this refugee memory is related to contemporary attitudes towards migrants. This chapter will shift the focus to a micro-history and oral history approach in order to elucidate the formation of Asia Minor refugee memory in the context of Europe's 'migration crisis.'

\section{Asia Minor memories of the past and the refugee assistance in the present}

\section{Memory}

\section{Refugee memory}

There has been increasing interest among historians in the relationship between history and memory. Specifically, scholars distinguish between individual and collective frameworks of remembrance. One category of scholars, primarily comprised of cultural historians being influenced by sociologists, such as Halbwachs, develop the role of collective memory through reconstructing the past within a social context and considering individual memory insignificant (Halbwachs 1980; Nora \& Kritzman 1996). On the other hand, focusing on individual recollections, oral historians give authority to the interplay between individual and collective memory (Passerini 1979; Thompson 2017) and elucidate the relationship among individual, group, and national memories (Gildea 2010).

In my analysis, memory is conceptualized through the interplay between its various levels. On one level, it is seen as an embodied experience of Asia Minor refugees at the individual level that is mediated through familial, collective, cultural, and national frameworks of remembrance. The second level consists of collective memory shared by individuals within a group with shared memories, and the third level refers to cultural memory or the national narrative that concerns society as a whole (Gildea 2013). The interplay between the different levels of memory is elucidated from Lesvos' residents, who illustrate that the Asia Minor refugee memory pervades the island's narratives not only at an individual but also at a collective level. The role of refugee memory seems to exert a major influence on the way the community of Lesvos perceives, interprets, and ultimately acts on issues related to migrants.

There is collective memory on the island, and this space where we are now with the beach was the space that received many refugees from 
Turkey.... People have the memory of forced displacement, or the refugee memory, from the past generations.

(Manager of a municipal refugee camp, non-Asia Minor refugee descendant 2017)

\section{Memory of trauma and its intergenerational transmission}

'[T]rauma describes an overwhelming experience of sudden, or catastrophic events, in which the response to the event occurs in the often delayed, and uncontrolled repetitive occurrence' (Caruth 1991: 181). In my analysis, the question of whether subsequent migration triggers traumatic memories of forced displacement, is explored through the examination of the idea of a reawakened image of trauma (Druker 2011).

I do not want to talk about this [forced displacement] nor hear anything relevant, it was enough that we experienced it.

(Kuriaki Tsapa, first generation Asia Minor refugee, cited in Kitromilides 2016: 109)

We are reminded every time we see refugees landing on the island's shores of the scenes of exodus our mothers had described. We too were refugees.

(Asia Minor descendant of the second generation 2017)

The intergenerational transmission of these memories is elucidated by the structure of 'post memory,' which 'is a consequence of traumatic recall but $[\ldots]$ at a generational remove' (Hirsch 2008: 106). Given that 'trauma is both the event and the memory of the event' (Thomson 2015: 18), in the case of Lesvos the wound of forced displacement is transferred from the first to the following generations through family memories. Political scientists, as well as psychologists and anthropologists, stress that identities shaped in the context of a traumatic historical moment can have a longlasting and intergenerational effect. Hirschon, referring to the Asia Minor refugee memory, notes that 'its strength and persistence into the successive generations is impressive' (1989: 17).

This picture [of the violent forced displacement] after all these years neither faded nor could be deleted from my memory. I transferred it to my friends, and later to my wife, and my kids.

(Alexis Alexiou, first generation Asia Minor refugee, cited in Kitromilides 2016: 8)

Now that we are getting old, we tell stories about our lives to our children. (Vasilis Chatziathanasoglou, first generation Asia Minor refugee, cited in Mourelos 2004: 446) 
The first generation did not speak about its trauma. The second generation spoke even less and only with their families. The third generation, being integrated in Greece, speaks and organizes commemoration ceremonies and refugee associations.

(President of refugee association, Asia Minor descendant of the third generation 2017)

Sometimes this indirect transmission happens in an unconscious and nonlinear way. Specifically, Asia Minor refugees of the first generation were not always willing to share their stories for fear of evoking their pain or not being understood. In relation to the preservation of memory through family narratives, Gildea (2015) notes that people usually tell their life stories to their grandchildren towards the end of their lives. In the case of Lesvos, refugee memory is experienced indirectly and symbolically though oral history and is passed on from one generation to another.

\section{Identity and values}

The idea of belonging

Investigating the lingering effects of refugee memories and the way in which inherited identities influence people's values and ultimately their attitudes towards subsequent migrants and refugees, my analysis is based on the collective and individual identity of displacement. Identity as a sense of belonging cannot be limited to a specific ethnic context. Multiple forms of identity such as class, race, gender, and ethnicity intersect in societies and create different processes and practices of identification. The identity of Asia Minor refugees was formed through the coexistence of multiple layers of religious, educational, economical, and cultural particularities. However, it should be noted that decisions that do not result from people's free will often cause difficulties in the identification process. Hirschon states that refugees are 'by definition minority groups ... that are distinguished from others according to criteria which are used by them and by outsiders to define an identity different from that of the host society' (1992: 158). Kitromilides (2006) argues that refugees' identification was shaped by the hostility of the native population. Indeed, the often orientalist perspective of the native population lies at characterizations such as 'baptized in yogurt' that stigmatized refugees for years. This sense of a separate identity has been consciously maintained across generations through family memories.

They [the native Greeks] did not like us at all. They were saying: 'It would have been better if your boat sunk and you drowned in the sea! You eat our bread.'

(Ermolaos Andreadis, 1972, first generation Asia Minor refugee, cited in Kitromilides 2013: 95). 
Contested memories and contemporary attitudes

Tracing the ambiguous relationship between history, memory, and contemporary attitudes, the complex identities of the historically formed subjectivities of Asia Minor refugees are unpacked in the depth of the different contexts in which individuals made sense of their past. Following different approaches, scholars examine the role of individual and collective past as sources of formulation of the present with regard to attitudes towards outgroups. Examining the role of shared histories, Rothberg notes that '[i]t is often difficult to tell whether a given act of memory is more likely to produce competition or mutual understanding - sometimes both seem to happen simultaneously' (2009: 11).

The role of refugee memory came to light in every interview, revealing a nexus between an increased sentiment of sympathy towards contemporary refugees and the island's past refugee experience. This powerful memory constitutes what Papataxiarchis (2016b) defined as the Greek paradox. Rooted in the island's memories of forced displacement, the Greek paradox can be used in order to explain, for instance, the fact that despite the political flux, the economic austerity, and the vast migratory arrivals, the residents of Lesvos organized themselves to oppose and, ultimately, to close the office of the Greek far-right party, Golden Dawn, which was the main anti-immigrant force on the island. The emotional identification of Asia Minor descendants on Lesvos with the contemporary migrants and refugees has become apparent in numerous cases, bringing to light values of hospitality and empathy. For instance, as it has been pointed out by one of the interviewees:

In 2015, I went to the bakery and saw a couple being loaded onto a tractor with food, etc. and I asked: where are they being taken? They replied 'Every Saturday we do this in memory of our ancestors.' A lot of this happened in memory of people's parents and grandparents.

(Member of a local NGO, Asia Minor descendant of the third generation 2017)

Another example is Lesvos' grandmothers, whose mothers had arrived on the island by boats in 1922, who fed refugee infants. These and other examples have become symbols of solidarity. For instance, "in official discourse, the "three grannies [became] the image of the Europe that we want," the "good face of Europe"” (Papataxiarchis 2016c: 4). Through such actions, the values of hospitality, reciprocal support, and tolerance, which are rooted in Lesvos' past refugee experience, are enacted today.

The sensitivity that the island has demonstrated is greater than in all other areas of Europe ... We attribute this firstly to feelings of solidarity 
of the local community that has, to a large extent, refugee roots from the refugee flows from Asia Minor.

(Officer of the Chamber of Commerce, Asia Minor descendant of the third generation 2017)

The residents of Lesvos are more sensitive to such matters because a third of them are refugees of the third and fourth generation, including myself. We are more sensitive towards these migrants and refugees because we know the way the native population welcomed our ancestors.

(Municipal officer, Asia Minor descendant of the third generation 2017)

However, going beyond the idealization of the Lesvos case, it should be noted that the present chapter neither suggests that due to the island's refugee memory the notion of otherness is deterministically surpassed nor does it aim to establish a causal link between memory of forced displacement and contemporary attitudes. According to some of the interviewees, people tend to identify to a higher degree with Syrian refugees. The term 'refugee' in Greece goes back to the successful integration of the Asia Minor refugees and has a strongly positive connotation (Voutira 1991). In contrast, some of the interviewees use the word migrant inscribing a negative connotation to people who come from countries such as Afghanistan, Somalia, and Iraq.

We help the Syrians that they have war, the rest why are they coming? People who are coming from Africa are not refugees.

(Engineer of Moria hotspot, Asia Minor refugee descendant of the third generation 2017)

I think that there was a higher level of sympathy and tolerance towards the Syrians.

(Officer of the Hellenic Coast Guard, non-Asia Minor refugee descendant 2017)

We love and support the contemporary migrants and refugees but we cannot identify with them. We are not the same.

(President of refugee association, Asia Minor refugee descendant of the third generation 2017)

Examining theories of prejudice reduction of outgroup discrimination for the increase of empathy and reciprocal support (Loizos 1999) and theories of competitive victimization and hostility against outgroups (Vollhardt 2012), it becomes apparent that contested memories are shaped in the case of Lesvos, increasing empathy towards those who are perceived as refugees and hostility or competitive victimization towards those considered to be migrants. 


\section{Conclusion}

Do forced displacement experiences leave a lasting memory that is transmitted from one generation to the next and that influences identities, values, and ultimately attitudes towards contemporary migrants and refugees? Focusing on the case of Lesvos, I traced how descendants of refugees think about subsequent migration through the historical parallel between the Greek-Turkish population exchange and the contemporary migration and refugee flows.

The narrative of the Asia Minor refugee memory is not static and passive, but is instead actively reshaped and contested over time. In this chapter, memory is seen as a dynamic oscillation between continuities and discontinuities of the past and the present, through which historically formed subjectivities are unpacked in the context of Europe's contemporary 'migration crisis.' The way the subjectivities of Asia Minor refugees and their descendants are shaped across different generations, multiple levels - individual, collective, national - is elucidated through the fluid interplay between memory, storytelling, and contemporary attitudes. In this light, the nuanced relationship between memory, identity, and values, the conceptual tools of this study, and the extent to which they inform and construct each other, creating different practices of belonging over time and potentially producing empathy or hostility, are examined.

According to the presented results, transmitted from one generation to the next through family history, Asia Minor refugee memories change over time from reticent in the first generation with the direct traumatic experience, to latent in the second generation that was trying to get integrated into the host society, and to reawakened in the following generations that, being fully integrated and facing another shock, rediscover their roots. Tolerance and empathy are increased towards ethnic out-groups that are perceived as refugees, while on the other hand competitive victimization, and in some cases, hostility appear towards those considered to be migrants.

Overall, despite the island's vast migratory arrivals and the bruised economy, people's attitudes are characterized by feelings of compassion and understanding. These sympathetic attitudes derive from the phrase 'we too were refugees' and from the values of hospitality and tolerance, which have been inscribed not only in the descendants' memory but also in the island's collective memory. The existence of the values of hospitality and tolerance regarding the reception of subsequent refugees and the acceptance of histories of people with shared experiences is explained through the island's refugee memory, which is transmitted from one generation to another.

The importance of refugee memory as an experience at the individual level, a collective memory within a group with shared experiences, and a cultural memory that concerns society as a whole is paramount with regard 


\section{M. Anastasopoulou}

to the reception of subsequent migration and refugee flows. In Greece, a country that receives a high number of migratory inflows and whose present composition of population is rooted in past relocation experiences, the significance of these memories and the extent to which they inform identities, values, and attitudes is paramount.

\section{Notes}

1 The data come from two of my research projects entitled: 'Coming to term with forced migration: an intergenerational study of Asia Minor refugee memory' and 'Tracing the conflicting dynamics of policy implementation: The case of hotspots in Greece.'

2 Oral testimonies of the first generation, derived from the Oral History Tradition archive of the Centre of Asia Minor Studies in Athens, will be also examined. This archive comprises 5,000 oral testimonies of the first generation of refugees and is classified according to Asia Minor geographical settlements.

3 Technically the term 'refugee' does not apply to the people who were forcibly displaced under the Lausanne Convention because they were granted citizenship rights in the host countries. However, the 'terms people use to describe themselves are sociologically significant' (Hirschon 2003: xiii).

\section{References}

\section{Primary sources}

Asia Minor descendant of the second generation (2017). Interviewed by Marilena Anastasopoulou in Lesvos, March 2017.

Engineer of Moria hotspot, Asia Minor refugee descendant of the third generation (2017). Interviewed by Marilena Anastasopoulou in Lesvos, March 2017.

Manager of a municipal refugee camp, non-Asia Minor refugee descendant (2017). Interviewed by Marilena Anastasopoulou in Lesvos, March 2017.

Member of a local NGO, Asia Minor descendant of the third generation (2017). Interviewed by Marilena Anastasopoulou in Lesvos, March 2017.

Municipal officer, Asia Minor descendant of the third generation (2017). Interviewed by Marilena Anastasopoulou in Lesvos, March 2017.

Officer of the Chamber of Commerce, Asia Minor descendant of the third generation (2017). Interviewed by Marilena Anastasopoulou in Lesvos, March 2017.

Officer of the Hellenic Coast Guard, non-Asia Minor refugee descendant (2017). Interviewed by Marilena Anastasopoulou in Lesvos, March 2017.

President of refugee association, Asia Minor refugee descendant of the third generation (2017). Interviewed by Marilena Anastasopoulou in Lesvos, March 2017.

President of refugee association, descendant of the third generation of Asia Minor refugees (2017). March 2017.

\section{Printed primary sources}

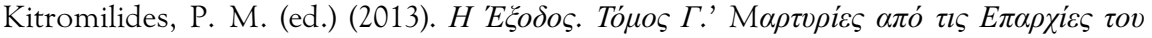

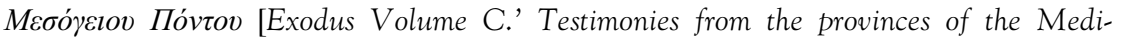
terranean Sea]. Greece, Athens: Centre for Asia Minor Studies. 


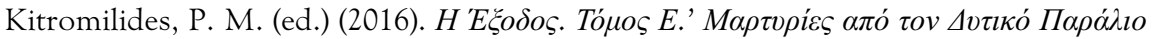

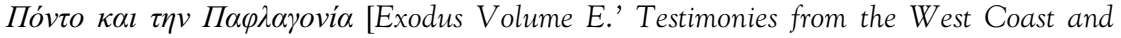
Paphlagonia]. Greece, Athens: Centre for Asia Minor Studies.

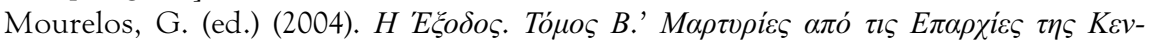

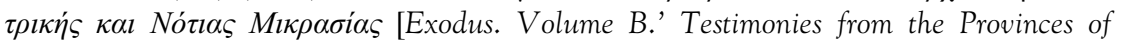
Central and South Asia Minor]. Greece, Athens: Centre for Asia Minor Studies.

\section{Printed secondary works}

Akgonul, S. (2009). 'Towards minority policies beyond reciprocity? The EU, Greece and Turkey,' in Anastasakis, O., Nicolaidis, K., \& Oktem, K. (eds), In the Long Shadow of Europe. Leiden, pp. 191-218.

Caruth, C. (1991). 'Unclaimed experience: Trauma and the possibility of history,' Yale French Studies 79(1), pp. 181-192.

Doumanis, N. (2012). Before the Nation. Oxford.

Druker, J. (2011). 'Trauma and latency in Primo Levi's The Reawakening,' in Sodi, R. \& Marcus, Millicent (eds), New Reflections on Primo Levi. New York, pp. 63-77.

Gildea, R. (2010). 'The long march of oral history: Around 1968 in France,' Oral History, 38(1), pp. 68-80.

Gildea, R. (2013). 'Utopia and conflict in the oral testimonies of French 1968 activists,' Memory Studies, 6(1), pp. 37-52.

Gildea, R. (2015). Fighters in the Shadows: A New History of the French Resistance. Cambridge, MA.

Gildea, R. \& Mark, J. (2013). 'Introduction,' in Gildea, R., Mark, J., \& Warring, A. (eds), Europe's 1968: Voices of Revolt. Oxford, pp. 1-18.

Halbwachs, M. (1980). The Collective Memory, 1st edn, New York.

Hirsch, M. (2008). 'The Generation of Postmemory,' Poetics Today, 29(1).

Hirschon, R. (1989). Heirs of the Greek Catastrophe, 1st edn, New York.

Hirschon, R. (1992). 'Memory and identity: The Asia Minor Greeks in Kokkinia,' in Papataxiarchis, E. (ed), Anthropology and the Past: Contributions to Social History in Modern Greece. Athens.

Hirschon, R. (2003). '“Unmixing peoples” in the Aegean Region,' in Hirschon R. (ed), Crossing the Aegean. New York.

Kitromilides, P. M. (1972). 'Contribution to the study of the Asia Minor tragedy: Evidence on the destruction of the Hellenism of Bithynia', Mikrasiatika Chronika, 15(1), pp. 372-398.

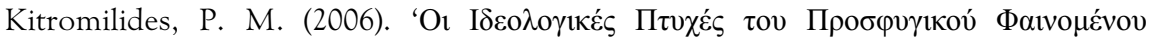

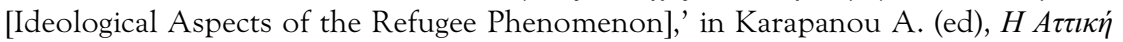

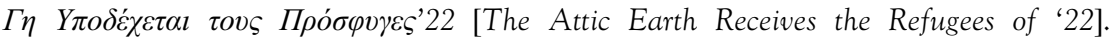
Athens, pp. 35-43.

Kitromilides, P. M. (2011). 'The end of empires, the Asia Minor catastrophe and the ecumenical patriarchy,' Bulletin of the Centre for Asia Minor Studies 17(1), pp. 29-42.

Ladas, S. P. (1932). The Exchange of Minorities: Bulgaria, Greece and Turkey. New York.

Loizos, P. (1999). 'Ottoman half-lives: Long-term perspectives on particular forced migrations,' Journal of Refugee Studies 12(3), pp. 237-263.

Mavrogordatos, G. T. (1983). Stillborn Republic: Social Coalitions and Party Strategies in Greece, 1922-1936. London. 


\section{M. Anastasopoulou}

Mazower, M. (1998). Dark Continent. London.

Nora, P. \& Kritzman, L. D. (1996). Realms of Memory: Rethinking the French Past, 1st edn, 1 vol. New York.

Papataxiarchis, E. (2016a). 'A great overturn: The "European refugee crisis" and the new patriotism of "solidarity”,' Contemporary Issues 132/133, pp. 7-28.

Papataxiarchis, E. (2016b). 'Unwrapping solidarity? Society reborn in austerity,' Social Anthropology, 24(2), pp. 205-210.

Papataxiarchis, E. (2016c). 'Being "there": At the front line of the "European refugee crisis", Anthropology Today 32(1), pp. 5-9.

Passerini, L. (1979). 'Work ideology and consensus under Italian fascism,' History Workshop Journal 8(1), pp. 82-108.

Pentzopoulos, D. (1962). The Balkan Exchange of Minorities and its Impact on Greece, 1 st edn. Paris.

Rothberg, M. (2009). Multidirectional Memory: Remembering the Holocaust in the Age of Decolonization. Stanford.

Salamone, S. D. (1987). In the Shadow of the Holy Mountain. New York.

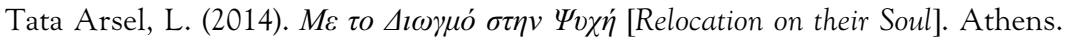

Thomson, A. (2015). 'Anzac memories revisited: Trauma, memory and oral history,' The Oral History Review 42(1), pp. 1-29.

Thompson, P. R. (2017). The Voice of the Past, 4th edn. Oxford.

Triandafyllidou, A. (2015). 'Turning the refugee crisis into an opportunity?: Current challenges for Greece and suggestions for action,' European University Institute 2015 (2), pp. 1-11.

Vollhardt, J. R. (2012). 'Collective victimization,' in Tropp, L. R. (ed), Oxford Handbook of Intergroup Conflict. Oxford, pp. 136-157.

Voutira, E. (1991). 'Pontic Greeks today: Migrants or refugees?' Journal of Refugee Studies 4(4), pp. 400-420.

\section{Websites}

Amnesty International (2015). 'Syria: voices in crisis,' November. Available at: www. amnesty.org/download/Documents/MDE2430252015ENGLISH.pdf

UNHCR (The UN Refugee Agency) (2018). 'Greece.' Available at: www.unhcr.org/ greece.html

UNHCR (The UN Refugee Agency) (2015). 'Lesvos Island - Greece,' UNHCR Factsheet, 12 November. Available at: www.unhcr.org/protection/operations/5645ddbc6/ greece-factsheet-lesvos-island.html 


\title{
3 Against the expansion of racism The experience of the Camp des Milles
}

\author{
Bernard Mossé
}

\section{The fight against racism and xenophobia}

At the request of President Macron, in July 2018, the National Assembly voted unanimously to remove the word race from Article 1 of the French Constitution of 1958 :

France shall be an indivisible, secular, democratic, and social Republic. It shall ensure the equality of all citizens before the law, without distinction of sex, origin, race or religion.

However, news of the change went relatively unnoticed. Cédric Villani, the famous mathematician and a Macronist deputé, suggested that the deletion should not be taken merely in the name of science 'which can always evolve' but in the name 'of a sense of common destiny with which we recognize all humanity as our brothers and sisters.' Villani's comments can be seen as an attempt to exempt scientists from ethical responsibility. French statutes use the term 'race,' for example, in the French definition of genocide, or as a criterion for discrimination. Use of the term oscillates between an undisputed social category, on one hand, and an ideological construct that must be challenged, on the other.

The migration crisis has influenced this political decision and recalls a tragic past. With nearly 60 million people affected by 'forced migration' worldwide (according to UNHCR), the migration problem is a pretext for creating confusion between the notions of migrant and refugee. The duty of hospitality is subordinated to the fear of the stranger resulting in a tragedy that sees thousands of exiles die during their journey, particularly in the Mediterranean. The logic of rejection of migrants and refugees that has characterized European policy for many years favors a logic of suspicion that reverses the legal order: the refugee is a potential migrant. This logic is amplified by the context of the fight against terrorism which reduces access to compassion. This humanitarian concern is contradicted by the police and security logic of Brussels, especially since it is ineffective and deaf to the analyses of scientists (Mazzella 2016). In terms of values, the 'migrant crisis' 
must be considered as a broader process that includes fear of foreigners, identity tensions, and the rise of nationalism. Racism and xenophobia are the common denominator. This combination of factors has already led Europe to collapse. The fight against this ideology is a moral necessity and a condition for peace and democracy.

In France, the campaign against racism has been supported by state institutions at various levels, by associations involved in anti-racist activities and services to migrants, and by memorial sites linked to the Holocaust or to slavery. This effort relies on a common definition of racism developed through scientific debate, to facilitate shared values, and collaborative action. Advancing this common understanding of racism is the purpose of the Foundation of the Camp des Milles: Memory and Education, a memorial site for a camp used for interments and deportations from September 1939 to 1942. One of the Foundation's goals is to work on themes of racism and xenophobia at every phase in the chain of knowledge: research, awareness, education, training, and cultural activities. Within the framework of the UNESCO Chair in Education for Citizenship, Human Sciences, and the Convergence of Memory, which it supports in partnership with the University of Aix-Marseille, the Foundation has created a series of initiatives to sponsor concrete projects involved in the fight against extremism, racism, anti-Semitism, and discrimination

Opened in 2012, the Memorial Site of the Camp des Milles now receives more than 100,000 visitors per year, half of whom are schoolchildren, and trains nearly 10,000 people per year, mostly executives and officers from the public service, armed forces, police, education, and tribunals, as well as local elected officials, trade unionists, office-holders, and employees of socio-cultural associations and companies. The Foundation also organizes events for youngsters from priority neighborhoods, private schools, and the Prévention judiciaire de la Jeunesse, for juveniles and adults in prisons, and youths who have been radicalized and educators working with them. Over the last three years, the Foundation has been asked by several ministries to carry out training programs for professionals in contact with new migrants and for the migrants themselves to develop their awareness of the values of the Republic.

The aim is to describe, from the point of view of a practitioner operating both in academia and in education, an experience of defending democratic values threatened throughout Europe and revealed by the migrant crisis. Its successes, obstacles, methodologies, and devices can be useful to many other actors in this struggle.

How has a memorial dedicated to the Second World War and the Holocaust become in a few years a center for training citizens about issues relating to racism and xenophobia and for developing resources on the defense of values in terms of hospitality to foreigners? The answer lies, in the first instance, in the history of the camp itself, since thousands of exiled foreigners were interned within its walls. The site has benefited from work carried 
out over a dozen years by a multi-disciplinary scientific council which, based on an analysis of the Holocaust and other twentieth century genocides, has documented the process by which a society can slide, step-by-step, towards mass massacre. Finally, the foundation has established a campaign of public awareness, education, training, and publication, using a didactic methodology based on historical knowledge and a sensitive approach to memory, drawing on an analysis of human and social sciences, and leading towards citizen education through the testing of values. Today, the Camp des Milles' work is recognized by both major institutions and social actors at local, regional, national, and international levels thanks to its UNESCO Chair and its scientific and memorial network. We are invigorated by daily interaction with schoolchildren, trainees, professionals, experts, and scientists, which ensures our examination of inherent tensions and necessary constraints is constantly renewed. This examination takes various forms: institutional and political to defend the model of national integration and analyze contestation; ethical, with a multi-cultural and a universal approach; conceptual: how do we define racism?; and strategic, focusing on the need to combat extremism and to avoid amalgams. It is perhaps Camp des Milles' position midway between state institutions and activist associations, between research and field work, between scientific solidity and practical flexibility, that has made it successful to date.

\section{The history of the Camp des Milles and its analysis}

\section{From arguments of exception to policies of extermination, a xenophobic spiral}

In conformity with a decree of November 1938 for the internment of undesirable foreigners, the French Army of the Third Republic requisitioned the nineteenth century brick factory in Les Milles, six kilometers from Aix-en-Provence, in Southern France, for the internment of 'enemy subjects' at the very moment that it declared war on Nazi Germany.

The history of the camp includes three periods: between September 1939 and the summer of 1942, reveal processes, from a policy of exception to a policy of extermination, which led to the deportation and assassination of more than 2,000 Jews considered to be foreigners at Auschwitz.

The first period, from the declaration of war in September 1939 to the Armistice in June 1940 during the Third Republic, reflects a wartime policy calling for the neutralization of enemy subjects, mostly Germans, present in France. Exception policies under military orders, understandable in wartime with the fear of an internal enemy, were applied indiscriminately and led to the internment of thousands of people who had been persecuted by the Nazis, often anti-Fascist intellectuals and artists exiled in France who thought they had found refuge in the land of human rights.

During the second period, following the defeat of France and the establishment of the Vichy Regime in June 1940, the camp reopened its doors. 
This time, the idea was to remove from France and its territories 'undesirable foreigners' who had defiled the country that now needed to be reconstructed without them. Authoritarian and clearly xenophobic politics led to the internment of people of 38 nationalities.

The third period began in July 1942, when Pétain arranged with the Nazis for the transfer of 10,000 foreign Jews (including Jews stripped of their French nationality) from the Southern Zone. Between August and September 1942, nearly 2,000 people were deported from Les Milles, including a hundred children that the Nazis had not requested. Five adults survived.

An arrangement targeting foreigners was allowed by a decree issued by the Third Republic in peacetime; it gradually transformed from a policy of exception, then exclusion, and finally extermination under French authority. The lessons to be drawn for today's world seem evident, but it has taken more than ten years of research and didactic reflection for us to understand how to transmit these lessons.

\section{A didactic course in three phases: from history to citizen education}

The itinerary offered to all visitors to Camp de Milles is composed of three consecutive sections: historical, memorial, and reflective. The historical section illustrates the mechanisms that resulted in the extermination of European Jews. It recounts first the rise of dangers, the emergence of authoritarian and totalitarian regimes in the 1920s and 1930s, then, drawing on the history of the Camp des Milles, it describes the steps which drew Europe towards genocide during the war.

In the memorial section, visitors walk through the internment areas - dormitories, assembly areas, guardians' refectory, etc. - which remain virtually in the same state as they were during the war. Quite apart from the massively powerful atmosphere inherent in an industrial site converted into an internment center, the museography activates all aspects of memory, including suggestive surroundings (gloomy corridors and smell of dust), witnesses' stories, historic areas (the 'legionnaires' corridor,' the 'escape galleries,' the 'suicide windows,' etc.), traces, graffiti, and works of art produced during the internment and reports of resistance by internees to inhuman conditions in which they lived after 1939.

The last phase, unique for a memorial site, offers the scientific keys to understanding the process which can lead a country from its ordinary state into the perpetration of mass massacre. This analysis, in generating research in human and social sciences (sociology, psycho-sociology, anthropology, economics, political science, law, philosophy), draws on a similar process of genocidal crimes throughout the twentieth century: Armenians under the Ottoman Empire, Jews and Gypsies in Europe, and Tutsis in Rwanda. A twenty-minute film presents the conclusions of this research. A graphic display presents this process in three phases which, when sown in fertile ground found in all countries, transforms 'racism into genocide.' 
This analysis allows us to develop educational projects which inform visitors about the importance of maintaining vigilance of elements that constitute the genocidal loam, around racism, and of understanding individual responsibility: fear of the other, stereotypes, prejudice, discrimination, extremist ideologies, passivity, blind submission to authority, group conformism, scapegoats, conspiracy theories ... the list is endless.

The Memorial Site has developed a didactic itinerary based on historical knowledge of a major tragic event of the twentieth century - the Holocaust, 'an anthropological caesura' in the history of humanity, according to Georges Bensoussan (2013) - that seeks to generate an emotional awareness through the veracity of places and traces. Generally speaking, it takes a universal angle, drawing on human sciences, to present the process which, in hindsight, has become clearly visible and can lead, anywhere and at any time, to the worst scenario. It is an opportunity not only for focusing on arguments relating to combating behavior that encourages such mechanisms to develop, but also for understanding the importance of values which underpin the need for vigilance. This is achieved notably through pedagogical workshops and training modules which use discussions and debates to explore ethical questions relating to our relationship with others. This approach has attracted interest and growing recognition from both institutions and actors involved in the combat against racism and the reception of migrants.

Our interaction is reinforced by highlighting points of contact between past and present. For example, against the background of rising danger and the imminence of war, the Evian Conference, a meeting of most of the free countries in July 1938, sought to organize the reception of refugees fleeing from Nazi persecution but ended in a total failure. The comparison with other genocides, such as those of the Armenians and of the Tutsi, highlights the passivity of the international community which is also particularly striking in today's migrant crisis. Similarly, the refusal of Cuba and the United States to allow the arrival of the MS St. Louis, with its cargo of Jews fleeing Germany, strangely echoes the recent wanderings of the MV Aquarius Dignitus in the Mediterranean. As a result, the attention paid to this place, the reaction of adults and youngsters, and the questions asked have clearly changed since the migrant crisis in 2015.

At the time of the deportations in summer 1942, warders, nurses, doctors, and pastors made it possible to save hundreds of Jews from deportation, while others, such as the Police Intendant, were careful to overfill the convoys. These edifying examples highlight the terrible fragility of humanity in some and the formidable capacity for resistance in others. And sometimes, the same men are thrown into what Primo Levi (1986) called the grey zone.

The last section of the memorial focuses on acts of mutual assistance and rescue. The 'Wall of Righteous Acts' presents the wide range of such acts in the face of genocidal crimes against Jews, Gypsies, Armenians, and Tutsis. These acts - whether individual or collective, courageous or disinterested demonstrate the importance of vigilance when faced with racist barbarism, and the active exercise of responsibility. 


\section{Memory of the Holocaust versus the fight for human rights}

The Memorial Site of the Camp des Milles is a private foundation and a nonprofit organization recognized as being of public interest. This is not insignificant. Jewish community associations and associations of former resistance fighters or former deportees, spent 30 years campaigning for the establishment of the Memorial Site. These associations have had to face political resistance: it was not easy to promote a history entirely under French authority that eventually led to the deportation of 2,000 Jews. The foundation is now supported by four ministries and several territorial councils, a situation that allows it to assume a position built on exceptional and impartial scientific and pedagogical bases. Let us be clear: the multidisciplinary and multi-genocidal approach, now recognized at the national and international level, would probably not have been possible under the aegis of a single official authority.

For 30 years, there has been a division of labor between the structures that support and implement national and European public policy and the associations that oppose and challenge them, while receiving public subsidies.

The Fondation du Camp des Milles holds a special institutional place among structures on which the State relies for its increasingly broad mission for promoting the values of the Republic and militant associations engaged explicitly in the political battle against extremism and in awareness campaigns about laws and practices that are likely to generate anti-democratic consequences. Above all, the Foundation's position reflects an ethic between defending the singular memory of the Holocaust and comparing the emergence of genocides. Its importance can be measured by the periodic attacks on its activities from two angles: certain parts of the Jewish community associations that have difficulty understanding how one can link the Holocaust to other forms of genocide and suspect the Memorial Site wants 'to drown the genocide of Jews' in a collection of incomparable mass massacres; ${ }^{1}$ and others who do not understand why the museography does not cover other crimes against humanity such as slavery, the Gulag, or genocides in the Balkans, Cambodia, Indians in Latin America, or anti-Revolutionary Vendeans in 1793-1796! A good number of Holocaust memorial sites in France and in Europe seek to fill the huge chasm between a culturalist approach that allows for recognition of a minority in the historical and political discourse, at the risk of exacerbating competition of memories, and a universalist approach, at the risk of creating scientific superficiality and a lack of differentiation between various forms of suffering.

A seminar in Amsterdam in 2011, organized by the Anne Frank House and the European Union Agency for Fundamental Rights and sponsored by the European Commission, brought together the major Holocaust memorial sites (Auschwitz Center, Mauthausen Museum, Kazerne Dossin in Belgium, Camp des Milles in France, etc.) on the theme of 'Holocaust and Human 
Rights Education.' A magnificent final mind mapping summarized the dense and wide-ranging discussions involving some 40 people and revealed the need for patient liaison work between Holocaust and human rights ('step by step...we must show the bridge'). From this mental map irrigated by the notion of discrimination, the words 'Jew' and 'anti-Semitism' were unbelievably absent.

The strength of the Camp des Milles' position lies on its dual scientific and ethical approach to the principle of 'convergence of memories.' This is based on the hypothesis that the genocide of the Holocaust was certainly unique but exemplary, and followed a process which can itself become universal. There are not only common elements in twentieth century genocides, including causal recurrences and regularities ('constant antecedents' to use Raymond Aron's phrase), but also similar human mechanisms, whether individual or collective. This hypothesis can be validated by a scientific convergence of three genocidal contexts which can be modelized into a recurrent processual layout that is both abstract and observable: using the epistemological approach, as a law, from the human sciences perspective, that is probable and contingent; 'a resistible process,' that leaves opportunities for free will, in terms of action; and that must call for resistance, in defense of values.

The Holocaust remains both unique and exemplary; as Georges Bensoussan (2013) has said 'the more we compare, the more we distinguish.' Today's memorial sites are taking the same path. The Holocaust Memorial in France has recently changed its program to reflect this approach. The Auschwitz Museum, in a strong partnership with the Camp des Milles, is going to develop a reflective section, while many other memorial institutions, such as the Holocaust Museum in Washington, the Kigali Museum in Rwanda, the Museum in Erevan in Armenia, the Sarajevo Museum in Bosnia-Herzegovina, in particular, have entered into discussions with the Foundation for collaborative projects on the 'Learning lessons from a violent past for a peaceful future. ${ }^{2}$

The scientific principle of convergence of memories contains an effective pedagogical aspect. Young people, during school visits, and sometimes adults in training, who prefer not to be told about the Holocaust and the suffering of Jews again, discover an approach which talks about and understands their own sufferings, the prejudices they have suffered, and have sometimes been the protagonists of, and can understand just how far such behavior can influence an entire country.

The Ministry of National Education takes the same approach with its publication of La Mission Génocides (Duclert 2019), a report inspired, if somewhat timidly, by this didactic multi-disciplinary and multi-genocidal model.

\section{Racism: in search of a definition}

Racism, like anti-Semitism, is central to processes that lead to the worst outcomes for humanity. In order to combat racism, it is critical to provide a 
pertinent definition comprehensible to all. The definition of racism used by the Camp des Milles has been developed by a multi-disciplinary scientific council over a ten-year period pulling together the entire content of the Camp des Milles museography. This definition is discussed every day in school workshops and adult training seminars, during which participants can not only sharpen the scientific concept and the civic message for all types of publics but also enrich the analysis of common representations and, in return, contribute to the work of researchers and trainers responsible for nurturing this dialogue.

Two definitions of racism regularly emerge from these discussions with young and old attendees, and professionals and non-professionals:

- A narrow definition explicitly inspired by exact sciences, including biology and genetics

- A much broader definition suggested by social sciences, sociology, and anthropology.

Given the rise of racist theories in many countries, and indeed within the academic community, on the one hand, and of extreme violence, on the other, which when combined could be explosive, these definitions pinpoint the responsibility of scientists with regard to this question.

In addition to defining racism and analyzing the scientific basis and its own history, the Fondation du Camp des Milles also serves to alert people to the societal implications of an increasing tendency by the exact sciences (biology, genetics, and neuroscience) to borrow concepts from the social sciences which could, given the 'return to race,' lead to their participation in the legitimization of racist theories. Its role must be to challenge researchers on the limitations inherent in science and, indeed, in reason.

The definition developed and diffused by the Memorial Site of the Camp des Milles states: 'racism is a collection of hostile ideas and behaviors towards people based on the belief in the biological existence of several human 'races' and in an inequality amongst them; it can end in the worst of tragedies'(Chouraqui 2015). ${ }^{3}$ This definition does not include its extension into daily language which relates to indecisive and fluctuating social or cultural characteristics. It also conveys the idea that to reject a person because of the supposed inferiority of the group to which they apparently belong is in fact a form of discrimination, but not necessary of racism. This definition thus has a double interpretation: the pseudo-scientific belief in the existence of races; and, the conviction that races are unequal. The fight against racism, if it is included in teachings/ education about inequalities and, in particular, against the damage caused by a hierarchical compartmentalization of populations (see Semelin, 2005; De Swaan, 2015; Chouraqui, 2015), must not ignore the importance of deconstructing the concept of race as developed by human and natural sciences. Although, for obvious reasons given the 
'anthropological caesura' that is the Holocaust (Bensoussan 2013), there was clearly a regression in racial theories in the post-war period. We have observed a worrying return to biological constructions of race in the hard sciences in recent years. It is not surprising that this situation is accompanied by the rise of authoritarian and extremist ideologies almost everywhere in the world, in both the United States and in Europe.

\section{The return of race}

The return of the race factor today can be seen in the work of a growing number of researchers who consider that racial categories are 'bio-genetically valid departure points' (Fullwiley 2008) or as an operational concept; as, for example, in the theory of 'genetic clusters' (Shiao et al. 2012). ${ }^{4}$ The issue here is less the reality, more the new character of this tendency (cf. Larrègue 2017).

In the social sciences, such a return is also obvious and benefits from a dual process: an ideological movement within the social sciences expressed in terms of ethnicities, and an epistemological approach that leans towards a growing integration of methods and concepts used in hard sciences, notably biology and genetics, in social sciences.

\section{Ethnicity and race}

The reappearance of race in the social sciences was masked for a while by the use of a concept of ethnicity. Ethnicity refers to the belief in a shared origin and to cultural elements, while race refers to natural, phenotypical characteristics, such as skin color. Ethnic affiliation can be perceived as positive and based on a choice, which can be multiple and flexible, whereas racial affiliation implies a sense of experienced inferiority, a clear division, and a definitive assignation (Perraudin 2014). This is undoubtedly the distinction that international conventions use when defining genocide as targeting 'a national, ethnic, racial, or religious group.' 5 The French text goes even further by extending it to groups determined by 'any other arbitrary criterion,' suggesting that previous criteria were not arbitrary. Race cannot be an arbitrary criterion. In the single reference 'to discrimination' in French law, the term is deliberately clarified by adding 'purported' to the word 'race,' an additional qualification always absent from other aspects of French law. ${ }^{6}$

Social sciences have a tendency to fuse, or should we say, 'confuse,' the two terms. As a result, articles in social sciences are published in defense of a 'dual conception' of race as a socially constructed and genetically identifiable category: this gives rise to 'ethno-racial' categories that seek to account for this duality (Perraudin 2014). Such confusion can be found in daily language where racism is seen today as any behavior of rejection not only in terms of race - strictly speaking - or ethnicity, but also in all forms of 
discrimination (against 'fat people,' 'blondes,' 'old people,' etc.) which both dilutes the racial question and trivializes its ideological foundation.

As has been already noted by Pierre-André Taguieff (1990), use of the vocabulary of ethnicity is in fact a euphemism for racism: it becomes 'racism without race.' It is as if certain researchers in the hard sciences see ethnicity as a Trojan horse, from the ethno-racial perspective, by which race can be reintroduced into the scientific debate, the social sciences being attacked as the soft underbelly: from this point of view, as a 'soft' science.

\section{The biologization of the social}

The introduction of genetics into the social sciences can be seen, in varying proportions, in economics, political science, and sociology, with a growing number of researchers actively promoting 'the integration of methods, concepts and data generated by genetics in their studies.' In particular, biological theories of race are emerging in the field of social anthropology (Larrègue 2017). There are no longer many researchers prepared to think that there are fixed, genetically distinct, and homogeneous human groups, in which physical traits, intellectual aptitudes, and even moral disposition are transmitted by heredity. The geneticist and anthropologist André Langaney wrote in 1992:

the notion of human races is an imprecise way to designate overlapping populations, since the unbelievable diversity does not lend itself to any simple or scientifically acceptable classification. [...] We have inherited the common usage of the words 'human races' from a sinister history and a misguided science. [...] Let us remember that it no longer belongs in today's vocabulary of science and that it is thus arbitrary.

(Langaney et al. 1992: 62)

Nevertheless, there is a great risk that we will see socio-cultural behavior interpreted in terms of neurological determinants referring to biologically racial groupings. However, this does not prevent scientists from using the term with growing frequency. A survey of titles and summaries of doctoral theses in France shows that the occurrence of 'race' has increased three- or fourfold in the last ten years. This tendency can be found in almost equal numbers in natural sciences and social sciences: biology, medicine, and psychology (the largest category), sociology, and anthropology. ${ }^{7}$

The worst is not always manifest. We must not throw out the baby of biology with the bath water of race. It is simply a question of refusing, in the name of science and of ethnicity, the recurrent pseudo-biological axioms that contribute to a theory of race. That is to say, to remain vigilant in neuroscientific and biological research, which is just as capable, if not more, as social sciences, given their guaranteed dominant position, of ideological derivatives or simply of dangerous assumptions. 


\section{The fight against radicalization and the right of asylum}

Since 2015, the new themes treated by the Fondation du Camp des Milles in its exhibitions, live presentations, and conferences focus on two significant avenues. On the one hand, radicalization has been added to the racism, antiSemitism, and discrimination that often lead to mass massacres. On the other, the issue of foreigners has become a specific element in the museum visit and the training program for certain groups. These themes do not, however, constitute a change of direction.

The question of radicalization was already identified during the analysis of processes as a key factor in the first steps from the breeding ground, through 'the active minorities,' focusing explicitly on the Communist Party and the Nazi Party in 1930s Germany, the Young Turks in the Ottoman Empire and Hutu Power in Rwanda. It implies a semantic clarification: first of all, the need to speak of radicalizations in the plural: as today with radical Islamism and extreme nationalism, two major totalitarian ideologies clashed in the interwar period; secondly, the preference given to the term extremisation: the term radicalization is linked to a return to the roots, which may concern, for example, non-violent ecological practices; the term extremisation has also been preferred because it allows to define both religious and nationalist extremisms.

Xenophobia and inhospitality were already present in 1938 when the previously mentioned Evian Conference failed. A few months later, while peace still reigned in the Third Republic, the 'Daladier Decree' allowed the internment without trial of undesirable foreigners. It was this decree that allowed Pétain to arbitrarily imprison thousands of Europeans at the Camp des Milles on their way to Marseille to find a ship to freedom.

These two themes were therefore already present in the historical foundation of the Memorial Site, but it is clear that the pressure of current events and political requests played a decisive role in their emergence. The migrant crisis and the attacks in Europe have affected populations, mobilized public authorities, and brought together memorial and anti-racist institutions, despite their differences, in defending shared values. The Camp des Milles has played its role here. It issued invitations to dozen Holocaust memorial sites in France to pool their educational programs in the light of this new situation. It has organized a debate between national directors of four anti-racist and universalist associations who then issued an unprecedented common declaration. Several ministries (including Interior, Justice, and National Education) have given the Camp des Milles a mandate to develop and organize training programs on radicalization and the reception of new migrants for agency officers and for the migrants themselves: requests continue to arrive. It is without doubt an indication of the efficacy of its pedagogical structure and its trainers, who regularly use the techniques of a moving debate or a forum-theatre to place attendees in a position to test anti-values, such as those so well-illustrated in France by the Vichy Regime (Roth \& Cohen-Laloum 2018). 
This is, perhaps, indicative of the attempts made by all the professionals to understand this theme. But such an approach is not without risk or abuse. Despite scientific and ethical precautions, these two themes converge, often dangerously. The many visitors who attend conferences on the process of extremization sometimes hear only the warnings about Muslim religious extremism, which though undoubtedly dangerous, is much further from power than nationalist extremism. The necessity of combating radicalization can generate amalgams and the rejection of others. The fight for values has to move forward on all fronts simultaneously. In periods of crises in particular, awareness of democratic values remains a delicate balancing act.

\section{Science in conscience}

It is not a question of reducing the migration crisis, which is first and foremost a crisis in the reception of migrants, to a mere question of racism. Nor can racism be seen as merely a refusal to offer hospitality to foreigners. Racism has deep roots which are reactivated in periods of economic, social, and political crisis and can be linked to an overall crisis of values. Based on stereotypes and prejudices that are easy to reactivate in a time of destabilization, racism driven by propaganda and language manipulation, can lead to a simplification of the world and a binarization of the population: us vs them, normal vs abnormal, useful vs useless, pure vs impure, human vs nonhuman, and ultimately living vs dead.

The work carried out by the Camp des Milles team for many years was carried out at the request of former resistance fighters and deportees who were not prepared to let racist, anti-Semitic, and xenophobic ideologies triumph. They were convinced that the process that led to genocidal tragedies in Asia, Europe, and Africa throughout the twentieth century can happen again. And that is indeed what is happening.

The rise of nationalism, the violent action by Islamic extremists, and the tragic indifference to the drama of migrants in the Mediterranean are the indicators and the instigators of mechanisms that could once again induce the worst scenario. Resistance must come from all levels of society and mobilize every social community. Some options have already been mentioned: associations and NGOs, which are highly mobilized but divided and are searching for markers; the law, through its words and the delicate balancing of liberty and security; and again researchers, who can encourage vigilance or legitimize extreme thought. They have a special responsibility. The biological interpretation of race still offers an ideological base that can easily be reactivated and colors its use in non-racist discrimination. AntiSemitism is evidence of this sedimentation of the rejection of Jews, by rehabilitating the 'changing figures of long-standing hatred' (Chouraqui 2015). Islamophobia is following along the same path by targeting Muslims in France in particular and Europe in general as we saw with anti-Arab and anti-Maghreb racism in the 1970s and 1980s. It has merely taken on new 
clothing. Scientists have already shown that they are capable of breaching in the name of reason - the limits of what is reasonable. While some researchers appear to be returning in this direction, and others do not see the danger, there is no reason for them to refuse an examination of conscience by evoking the freedom to carry out research.

We must not underestimate the recurrent processes that, based on racism, rejection of foreigners, and extremism, may trigger a spiral towards mass violence, or even genocide, as the researchers at the Camp des Milles have discovered.

The model proposed by the Camp des Milles Foundation is obviously not the only one possible in this fight. It can provide food for thought for all stakeholders, from researchers and educators to decision-makers and politicians. This model begins with a place of memory that provides a strong local and European reference point. It articulates memory and history, the sensitive approach, and the scientific approach of the past. It is based on a close and constant link between research, training, and dissemination. The mobilization of the human and social sciences makes it possible to identify a recurrent and universal process that can lead a society towards the worst tragedies. It is on the basis of this scientific analysis that a discourse of education is constructed: education to combat discrimination and racism and xenophobia, that links the past, present and future. This discourse is not only about fear. It involves the appropriation, or re-appropriation, of values: the values of democracy.

The strength of this model lies in the commitment and diversity of a team that works with all publics: education, urban policy (disadvantaged areas), justice, minors and adults, army, police officers, elected officials, and politicians. Each audience has its own values, but they are aware that they are working in a place that addresses everyone with the same foundation. In return, these exchanges reactivate scientific and didactic contents almost permanently thanks to a team of researchers in direct contact with the trainers, with the flexibility allowed by an institutional place that works, in part, as an association of public utility. This model can inspire other institutions and encourage them to create synergies between research, training, and socio-cultural actors. This is the path that the University of Aix-Marseille seems to be taking with the creation of an Institute in human and social sciences in which the Foundation of the Camp des Milles should be a partner and in connection with the creation of a European Civic University (CIVIS).

The gamble of values education based on the convergence of memories will overcome is far from won: it deserves to continue and be shared.

\section{Notes}

1 As the arguments of the historian Annette Wieviorka put forward during her presentation at the seminar of the Conseil Représentatif des Institutions Juives de France (CRIF - Representative Council of French Jewish Institutions) on the theme 'Mémoire des génocides: un regard vers le futur,' 2019, Camp des Milles. 
2 According to the name of the seminar programme, bringing together the Museums of Buchenwald, Sarajevo, and the Camp des Milles (2019) under the aegis of the Office franco-allemand pour la Jeunesse (Franco-German Youth Office).

3 Anti-Semitism is defined as 'an ensemble of hostile ideas and behaviours towards Jews for their religion, their pretended 'race' and/or the social, cultural and political group that they are thought to constitute. It includes a racist dimension at the end of the 19th century.' This definition brings out the specificities of anti-Semitism for which the foundations are multiple and cumulative and the distinct forms in the present.

4 The Genomic Challenge to the Social Construction of Race. Shiao and his colleagues defended an analysis by bunches which would define relatively identifiable human groups according to thoroughly entangled biological and sociological criteria that legitimize the term of race/ethnicity.

5 According to the jurisprudence put forward by the Prosecutor C. Akayesu to the ICT for Rwanda, an ethnic group is defined by a common language and culture; or which can be distinguished as such or recognized as such, including by the authors of crimes; $a$ racial group is based on hereditary physical traits, often identified with a geographical region, independently of linguistic, cultural, national or religious factors (1998-1999).

6 With regard to injuries and defamation on grounds of racism and discrimination: 'an infraction committed towards a person or a group of persons because of their origin or their affiliation or non-affiliation, real or supposed, to an ethnicity, a national, a supposed or a specific religion.' 'Supposed' was added in 2017 in a law passed in 1992.

7 Across all disciplines, we have identified 229 doctoral theses in France for which the description includes the word 'race' between 2008 and 2012, 614 between 2013 and 2017 (using the official database 'thèses.fr').

\section{References}

Aron, R. (1969). La philosophie critique de l'histoire. Paris: Points.

Bensoussan, G. (2013). Pourquoi interroger la Shoah aujourd'hui?Mémorial de la Shoah, Conférence, Paris.

Chouraqui, A., Veil, S., \& De Gaudemar, J.-P. (2015). Pour résister à l'engrenage des extrémismes, des racismes et de l'antisémitisme. Paris: Cherche-Midi.

De Swaan, A. (2015). Diviser pour tuer. Paris: Seuil.

Duclert, V. (2019). Rapport de la Mission Génocides. Paris: CNRS.

Fullwiley, D. (2008). 'The biologistical construction of race: "Admixture" technology and the new genetic medicine,' Social Studies of Science 38(5), pp. 695-735.

Langaney, A. Hubert, van Blijenburgh, N., \& Sanchez-Mazas, A. (1992). Tous parents, tous différents. Bayonne: Éd. Raymond Chabaud,

Larrègue, J. (2017). 'La criminologie biosociale à l'aune de la théorie du champ,' Déviance et Société 2(41), pp. 167-201.

Levi, P. (1986). Les naufragés et les rescapés. Paris: Gallimard.

Mazzella, S. (2016). Sociologie des migrations. Que sais-je?Paris: PUF.

Perraudin, A. (2014). Les discriminations ethnoraciales dans la gestion du projet migratoire. Tours: Programme de recherche CNRS.

Roth, X. \& Cohen-Laloum, J. (2018). Faire paraître les valeurs de la République par l'expérience de leur antivaleur. Grenoble: Programme de recherche CNRS.

Semelin, J. (2005). Purifier et détruire. Paris: Points.

Shiao, J. L., Bode, T., Beyer, A., \& Selvig, D. (2012). 'The genomic challenge to the social construction of race,' Sociological Theory 30(2), pp. 67-88.

Taguieff P. A . (1990). La Force du préjugé. Essai sur le racisme et ses doubles. Paris: Gallimard. 


\title{
4 The Moral Panic Button ${ }^{1}$

\author{
Construction and consequences
}

\author{
Márton Gerö and Endre Sik
}

\section{Introduction}

In January 2015, when the infamous terrorist attack on the editorial office of Charlie Hebdo happened, the Hungarian Prime Minister, Viktor Orbán was inclined to express his solidarity with the victims. A couple days later, just as he was about to fly to Paris to participate in the solidarity march, he drew a frightening picture of rising terrorism in Europe. He not only blamed European politics for the increasing threat of terrorism, but also political correctness and, most importantly, the so-called 'economic immigration and immigrants' (Index 2015). The following weeks experienced the birth of a campaign blaming migration for many of the problems of Hungary and Europe, portraying migrants as posing a threat of losing employment, increasing crime, and dissolving national culture, and continuously stating that the Hungarian government will commit everything to stop migration. The only problem was that, although the number of asylum seekers was increasing in the spring of 2015, they were hardly 'flooding' Hungary. The sudden increase in the number of arriving asylum seekers lasted only for a couple weeks and almost all of them only passed through Hungary (Bernát et al. 2015). Although since then, the number of arriving asylum seekers has returned to its normal level, the topic of immigration is still the central topic of the government's and Fidesz's political communication.

In September 2018, a new media corporation was founded, the Central European Press and Media Foundation. Throughout the next few months, the Foundation became the largest actor in the media market, owning 29 media companies, two television channels, a major national daily newspaper, the second largest online news portal, all county-level newspapers, one of the largest tabloids, and the largest freely distributed advertising newspaper. The most surprising thing about the Foundation is not the speed of its growth, but the fact that the former owners of these media outlets handed over their ownership for free. Thus, the Foundation acquired companies worth hundreds of millions of Euro without paying a single eurocent.

What is the connection between the two events? In our opinion, they are important steps of the 1) establishment, and 2) tailoring of the government's 
media organization toward a more fitting form (i.e., centralized, more controllable, and efficient, etc.) of the Moral Panic Button (MPB).

\section{The Moral Panic Button}

The concept of the MPB draws heavily on the theory of the moral panic developed by Stanley Cohen (1972). The moral panic involves the exaggeration of existing phenomena, picturing them as existential threats to the national community and explaining their causes by scapegoating and pointing to images of an enemy.

The ideal type of moral panic should focus on a 1) important, seemingly life-or-death, threat which 2) may have serious and lasting negative effects on 3) a large - or at least loud and visible - social group. It has to have 4) an identifiable person/group of the wrongdoer(s) who 5) can be blamed for the threat. 6) The 'problem' becomes a major topic for more and more actors, and in the course of the panic, 7) the level of hostility against the scapegoats increases. 8) Finally, the moral panic runs its course and disappears, often as quickly as it erupted.

The moral panic often involves specific language; the discourses of moral panics often use 'relatively fixed lexical and syntactical forms' (Cohen 2011: xxiv). For example, asylum seekers are often described using metaphors of water (flood, wave) or depicted as an invading army. Finally, moral panics need theories explaining why the dramatic event happened and emphasizing that the underlying mechanism is universal, thus it could happen again and in other places (Cohen 2011).

As to the origin of the moral panic, it can be a bottom-up one, when rumor or gossip initiates and widens the concerns of a local problem. It can also be the result of an idea which trickles down from the elite through the media. Opinion leaders of all sorts (editors, politicians, 'moral entrepreneurs,' the so called 'right-thinking people') use these channels to diagnose the problem and offer a remedy (Cohen 1972; Goode \& Ben-Yehuda 1994).

The Moral Panic Button concept (Sik 2016; Barlai \& Sik 2017) can be seen as a special version of Cohen's top-to-bottom, elite-engineered moral panic, but in this case, it is the government that induces the moral panic and uses it as a major tool of its governance.

The MPB, however, is much more than just a simple government-initiated moral panic. It is far from being simply a hardcore version of a top-tobottom type of moral panic. All of the characteristics of a moral panic are present in the operation of an MPB, however, they constitute only the necessary but insufficient conditions of an MPB. The MPB 1) assumes strong governmental control of the media, 2) the use of various propaganda instruments beyond the mass media, 3) continuously selects new scapegoats (while keeping the previous ones as well), and uses these combinations to hatemonger, 4) applies strong framing techniques (e.g. the monotonous repeating of simplified messages, using fake information and misinformation to 
humiliate and ridicule the enemy, etc.), 5) has uncontrolled financing from the state budget, and 6) flexibly incorporates (often unofficially) pro-government actors, such as think-tanks, NGOs (church, sport, civil organizations), municipalities, and for-profit firms (owned by 'friendly oligarchs'), etc. which are intertwined and organized by a few core state institutions.

\section{The construction of the MPB in Hungary}

In early 2015, after the sharp and fast drop of their popularity, the Hungarian government tried desperately to come up with ideas to regain the sympathy of their potential voters. For example, they experimented with opening a discussion in which they suggested the re-introduction of the death penalty and/or fueled suspicion towards the treacherous civil society. These ideas, however, failed.

In January 2015, just as the worst public opinion results came out, they discovered the merit of the terrorist attack mentioned at the beginning of this chapter as the basis of a 'threat from migration-type' moral panic construction. While the Hungarian Prime Minister expressed his solidarity with the victims, his statement issued on the occasion on January 11 was about the increasing threat that terrorism posed to Europeans' everyday life:

Our reality today, in Europe, is the increasing presence of terrorism. Its presence is growing day by day. It is the 'European man' who is under attack: the freedom and lifestyle of the 'European man.' All of this is threatening the safety of our everyday life, therefore we cannot afford not to face it.

(Népszava 2015.)

Then, he expressed his commitment to fighting this threat and stated that political correctness and the sclerotic EU are hindering the proper defense of Europe.

Soon, the government discovered that the result of this experiment was promising and decided to use it as the basis for further moral panics, and so on and so forth. They started beta-testing the MPB. ${ }^{3}$

As we have stated above, the main aim of the ruling elite was to regain the popularity they needed to remain in power. To achieve this goal, Fidesz needed to rule the discursive space. This required three things: 1) a hegemonic position in the media, 2) a proper topic for fearmongering, and 3) proper targets for scapegoating.

In the Introduction, we showed the last step (the creation of the huge state-controlled media entity) of the state's achieving of a hegemonic position in the media. However, Fidesz started this process immediately after winning the Parliamentary election in 2010. The standard technique was a slow acquisition of various media outlets and either re-directing their political orientation or closing them down. To achieve these aims, the state used three techniques: 
1 Undermining of the independence of the organizations responsible for overseeing private and public media;

2 The manipulation of access to the market resources necessary for media market activities; and

3 The manipulation of the information environment by controlling the access to public information and the political agenda (Polyák 2019: 283)

According to Bajomi-Lázár (2013: 76), the new institutional structure of the media 'may be defined as a strategy aimed at extracting from the media resources such various services.' The redistribution of media power started with the Media Act of 2010, which led to two major transformations. First, it established the Media Council and the National Media and Info Communications Authority with a high level of authority over media institutions. Second, it merged the dispersed public media institutions into one central public service foundation (Bayer 2011). The concentration of a high level of authority and massive funds into a single institution which is led by an appointee of the Prime Minister was followed by the suspension of media subsidies previously given to privately run TV stations (Rovó \& Dull 2016).

The second phase was to occupy the privately-owned media space by taking over or exterminating media assets that were critical to the government. Between 2010 and 2014, the main figure in securing the hegemony over the media was one of the founding members of Fidesz and a longstanding friend of Viktor Orbán, Lajos Simicska, who owned the most important pro-government media outlets. However, due to personal differences, this oligarch turned against Fidesz, and the formerly pro-government media became anti-governmental as quick as lightning. Thus, after 2014, Fidesz needed a new media strategy. First, Fidesz-related entrepreneurs acquired well-established and formerly critical news outlets (such as the second largest online news portal, the second most popular commercial television channel, and local newspapers). Second, parallel to occupying the existing media, they established new and loyal media outlets and radio channels. Third, they centralized the existing pro-government media under the ownership of loyal entrepreneurs, and started to rule out several prestigious, independent, and critical newspapers (Polyák 2019).

The third phase, which took place in 2018, started with the re-allocation of the media outlets previously owned by Simicska, who, after Fidesz won the Parliamentary election in 2018, sold all his media assets to a friend loyal to the government. The new owner appointed a new editor the day after the acquisition happened. But the most important element of the third phase was the establishment of the already-mentioned state-controlled foundation. With this organization, the pro-government media can be instructed directly by the Party.

The second thing that Fidesz needed to do in order to dominate the discursive space was to find a proper topic. The optimal qualities of such a topic were as follows: 1 ) simple (easily understood by the average citizen), 2) 
already popular among the public, 3) having a relevant moral component (i. e. connected to some basic element of the dominant value system), and 4) sensitive enough to be used as a potential threat to create a panic reaction.

In early 2015, the Hungarian government raised the issue of reintroducing the death penalty to the Hungarian legal system (Bugaric 2016). However, soon it turned out that the reintroduction of death penalty would contradict basic international contracts signed by Hungary, so the topic was dropped. Instead, the government turned to the topic of immigration, and at the same time, they repeatedly tried to attack civil society organizations.

Since the danger of civil society is a regularly returning topic of the government, we need a more detailed explanation why it did not serve well as a triggering issue of the Moral Panic Button. Fidesz tried to initiate an NGO threat-based moral panic already in 2013: the target was a representative organization of the Norwegian Civil Fund in Hungary, ${ }^{4}$ which distributes funds through selected civil society organizations. The government claimed that the representative organization (in fact a consortium of civil foundations) financed the political activity of the opposition. It launched a campaign against them as well as the recipients of the grants and pictured them as organizations representing foreign interests (Torma 2016). ${ }^{5}$ The Prime Minister even mentioned this case in his annual speech at Tusnádfürdő: 'I looked at civil society in Hungary apropos of debates over the Norwegian funds ... and what I saw were paid, political activists. Paid political activists sponsored by foreigners!"

Despite the government's various efforts to criminalize the targeted NGOs, this topic failed to become a good topic to generate moral panic. This is caused partly by the fact that the level of trust of the Hungarian society in civil society is higher than in politicians or in the Parliament (Hajdu 2014; Péterfi 2016) Furthermore, the topic is irrelevant to the majority of Hungarians.

With immigration, it is the opposite. Most people have an opinion on this topic, and Hungary has been one of the most xenophobic countries in the European Union since 2002. ${ }^{8}$ Figure 4.1 shows that the level of xenophobia was always much higher than in other European countries.

The third factor needed to dominate the discursive space by the government was a proper scapegoat. The choice of 'immigrants' is partly explained by the comparatively high and increasing xenophobic attitudes of the Hungarian population (Figure 4.1). Thus, it was easy to apply already existing frames to the scapegoats. ${ }^{10}$ Later, when additional scapegoats were added (such as George Soros, the liberals, civil society, UN, and Brussel's bureaucrats), Fidesz adapted a new frame to the old/new mix of scapegoats, all belonging to a worldwide conspiracy against Hungarians (this frame also equals the Hungarian nation with the Orbán government). The feeling of having been mistreated, cheated, undervalued as well as oppressed and exploited has a long tradition in Hungarian culture. These elements of ethnocentric values are used in the current framing of 'Them,' in which 'liberal' 


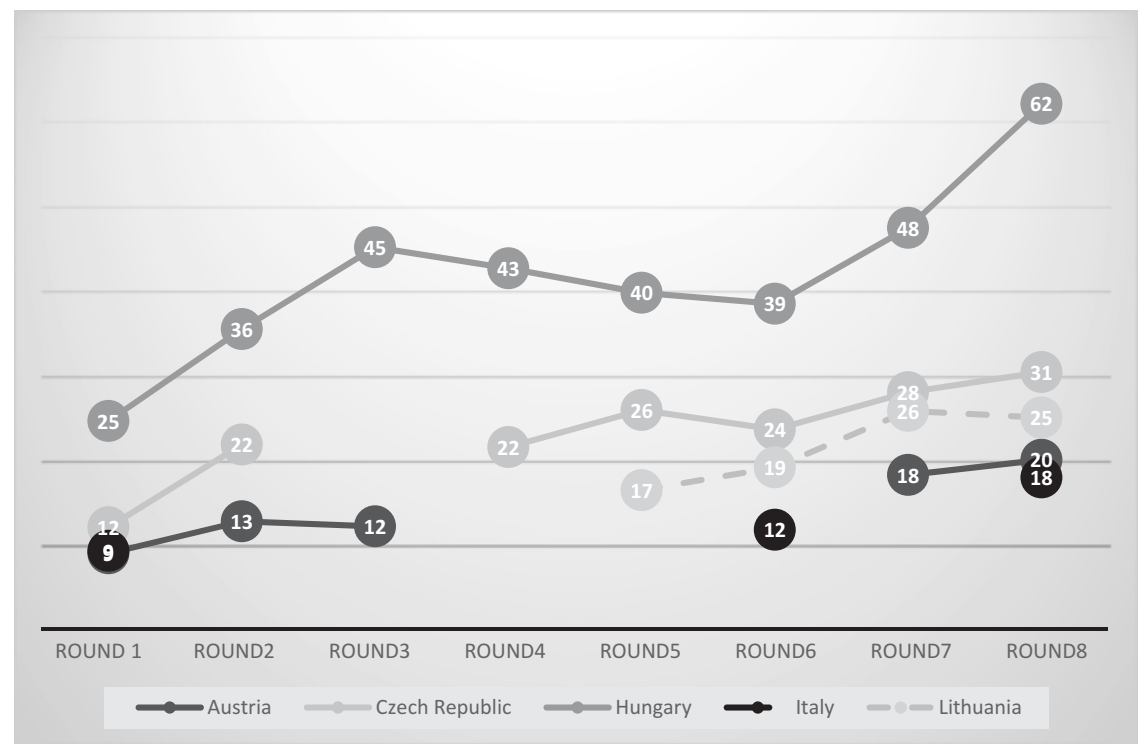

Figure 4.1 Countries with increasing levels of Rejection Index between 2002 and 2016, European Social Survey, percentage of $15+$ population $^{9}$

Source: The figure is based on Messing \& Ságvári 2019: 25

discourse is an empty signifier, a foreign wealthy banker is an usurper, international organizations are colonialists, etc. Moreover, this discourse smoothly uses the disguised but well-known elements of the anti-Semitic discourses of the twentieth century (Kende 1996; Kalmar 2018).

\section{The Hungarian version of MPB}

The main characteristics of MPB in Hungary are as follows:

There are three types of actions: information campaigns, national consultations, and voting-based actions. While the first type of pressing of the Moral Panic Button is the most prevalent and is conducted via the media (TV, radio, on- and off-line newspapers and billboards), the latter two actions (the four national consultations and the three actions involving voting - the quotareferendum, the Parliamentary and EU elections) reached all Hungarian households.

The information campaigns usually both precede and follow a national consultation and/or the referendum/election. Those preceding them serve to frame the topic, while those following them serve to reinforce the original message and claim victory (which is always greater than earlier ones).

The frames and the language are repetitive and simple, and while always adding new elements to the original frame (Europe and its value system, i.e. Judeo-Christianity and/or European culture is threatened by migration, 
Hungary is fighting a war and is unjustly treated by those whom we defend), the contexts of all pressings of the MPB are carefully tailored to a concrete situation. The scapegoats (EU, Brussels, Soros, UN, civil society, Merkel, etc.) are always the same, but they appear in different configurations.

Figure 4.2 shows the structure of the MPB. The figure contains all seventeen pressings we identified as separate, though overlapping, acts of the $\mathrm{MPB}$. The footnote contains the essence of these pressings. In the following paragraphs, we briefly demonstrate some of them, just to illustrate the details of the operation of MPB.

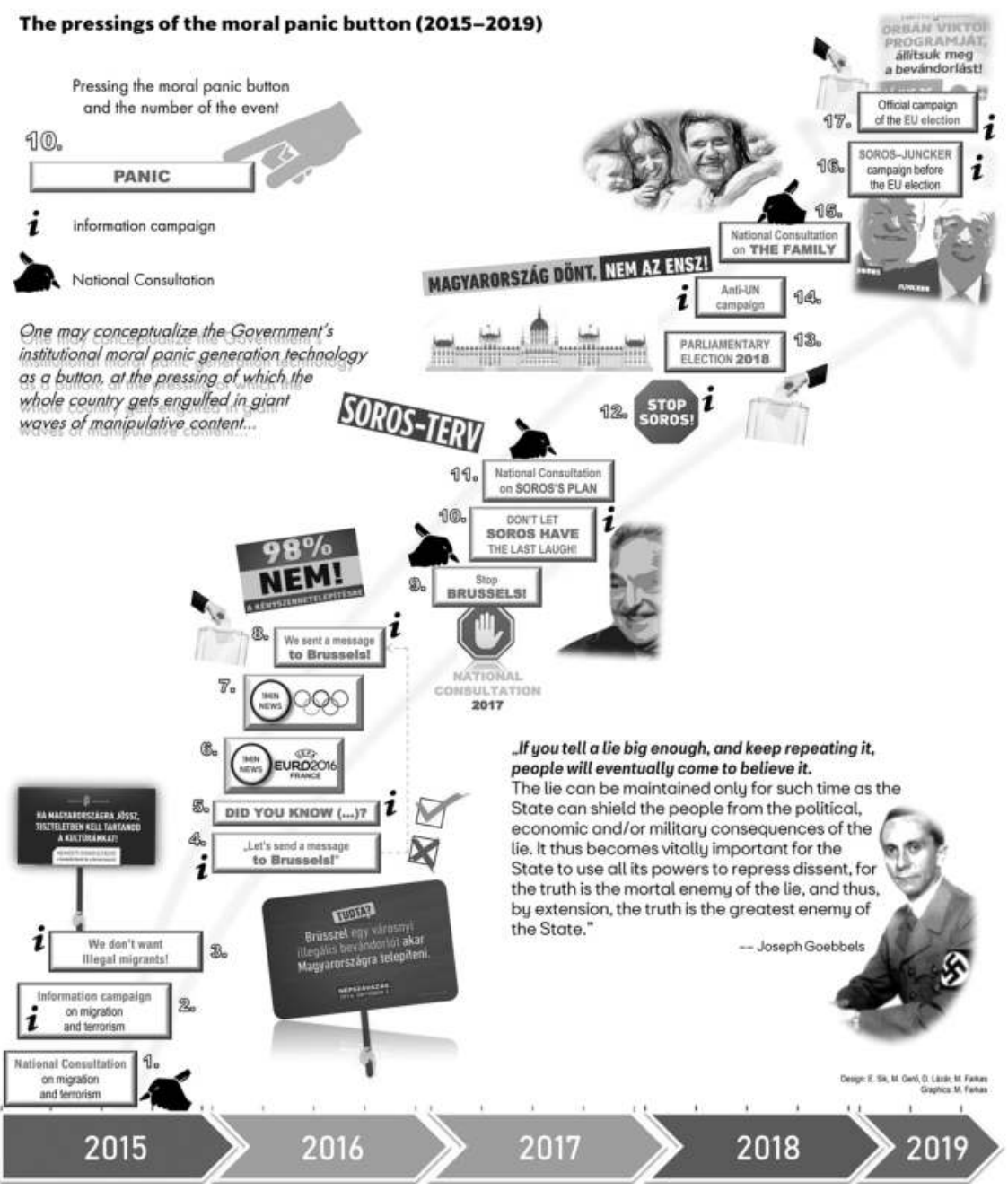

Figure 4.2 The pressings of the Moral Panic Button (2015-2019) ${ }^{11,12}$ 
The first example is the content of the national consultation on immigration and terrorism (Pressing 1, Figure 4.2). This example shows how all national consultations were used as fake public opinion surveys to frame the topic of migration. In Box 4.1, we selected some of the questions of the consultation questionnaire (Prime Minister's Office 2015). ${ }^{13}$

\section{Box 4.1 Three questions from Hungary's 'National Consultation on Immigration and Terrorism'}

1) We hear different views on increasing levels of terrorism. How relevant do you think the spread of terrorism (the bloodshed in France, the shocking acts of ISIS) is to your own life?

Very relevant

Relevant

Not relevant

3) There are some who think that mismanagement of the immigration question by Brussels may have something to do with increased terrorism. Do you agree with this view?

I fully agree

I tend to agree

I do not agree

4) Did you know that economic migrants cross the Hungarian border illegally, and that recently the number of immigrants in Hungary has increased twentyfold?

Yes

I have heard about it

I did not know

It is obvious, even for a first-year undergraduate sociology student, that in the case of Questions 1 and 3, the wording of the questions is suggestive and the answer items are unbalanced, and that the function of Question 4 is only to give (incorrect) information on migration. ${ }^{14}$ 
We can conclude that the so-called national consultations in Hungary are more akin to direct marketing than to a public opinion survey: these are short questionnaires sent to every Hungarian citizen which contain biased questions to sell the messages of the government. They are also far from the consultative tools of a democracy, since the topic is always the choice of the government, the questions are biased, and due to a lack of public meetings and publicly available rules of the procedures and control mechanisms, they can hardly be considered as consultations at all. ${ }^{15}$ They serve only two purposes: 1) to manipulate the population and 2) to reinforce the truth of the message by boasting about the strong support of the government's policies.

The second example is from an information campaign (Pressing 3, Figure 4.2). In this case, the MPB operated by using three simple messages, ${ }^{16}$ suggesting that refugees are a threat to job security and to the cultural values of Hungarians, and that they are likely to be criminals.

The third example shows how MPB incorporated fake news into its technology. The pre-referendum information campaign (Pressing 5, Figure 4.2) used the slogan: 'Did you know?,' supposedly providing information about the settlement quota and immigration. The examples ${ }^{17}$ clearly highlight the fakeness of this 'information campaign.'

As to the quota referendum (Pressing 8 , Figure 4.2), the question asked ${ }^{18}$ was intentionally biased, since 1) it referred to a non-existing conflict between Hungary and the European Union and 2) the question reflected the discussion about the settlement quota as if it were already decided, although this was not the case (EKINT 2016; Bognár, Sik \& Surányi 2018). The communication of the result of the referendum is a clear example of the manipulative communication of MPB - in the post-referendum campaign, the government communicated the fact that $98 \%$ of those who voted were against the quota, but failed to communicate that the referendum was invalid, since fewer than $50 \%$ of the citizens eligible to vote participated.

The pressings of MPB from number 10 and above 10 (Figure 4.2), contain new combinations of 'old' and 'new' topics, as well as 'old' and 'new' scapegoats. Although the issue of immigration was always present, the main 'enemy' changed and involves European Union's bureaucrats, George Soros, and the United Nations, all of whom are forcing Hungary to give up its position as defender of European culture. This shows a shift of the discourse, i.e. while at the beginning the information campaigns suggested that Hungarian or European culture was in danger because of the migrants, at the end of the campaign emphasis was on our national sovereignty endangered by a worldwide conspiracy of foreign oppressive forces using migrants as their puppets.

\section{The immediate consequences of the success of the MPB: obedient public opinion, polarization, and xenophobia}

The MPB has proven to be successful in its main aim: to overcome the loss of popularity of Fidesz at the end of 2014 (Figure 4.3). ${ }^{19}$ However, when the 


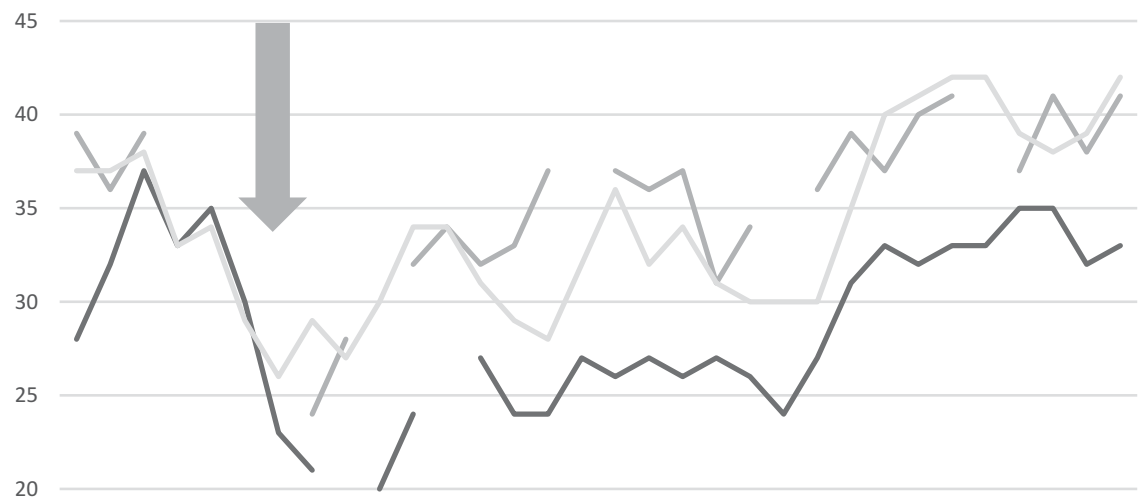

15

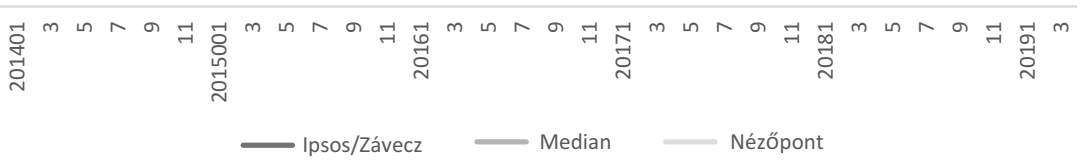

Figure 4.3 The level of popularity of FIDESZ (proportion of potential voters among those entitled to vote) 2014-2019

Source: Own design. The arrow shows the significant drop of popularity. Calculations are based on the data of the three public opinion research firms who conducted surveys during the entire period. The data is available at: Sik 2019.

use of MPB proved to be successful in gaining back the lost popularity of the government within just a few months, it became the main tool of maintaining popularity. Moreover, after several pressings, the MPB became a smoothly running machine used to mobilize the voting camp of Fidesz.

The success of the MPB is clearly demonstrated by the changing directions of the public opinion as well, i.e. the population follows the messages that the MPB emits towards them. Figure 4.4 demonstrates that the shift between the prevalence of threats of immigration, terrorism, and national sovereignty from 2017 to 2018 corresponds to the change in the framing of the 'refugee crisis' in the MPB. ${ }^{21}$ Figure 4.5 shows that the choice of the main enemies changed as well, in accordance with the influence of the MPB: the actors of the international conspiracy became much more important. Furthermore, not only was the prevalence of mentioning international actors higher, but the relationship between threats and 'enemies' became stronger: among those, who perceived external threats to be the most important, the mentioning of external enemies, with the exception of immigrants, doubled in a year.

Through the MPB, the government defines the core topics of the public discourse to make sure that their sympathizers learn the language of full agreement. However, this leads to increasing polarization within society: ${ }^{23}$ while Fidesz sympathizers perceive that external threats (losing national 


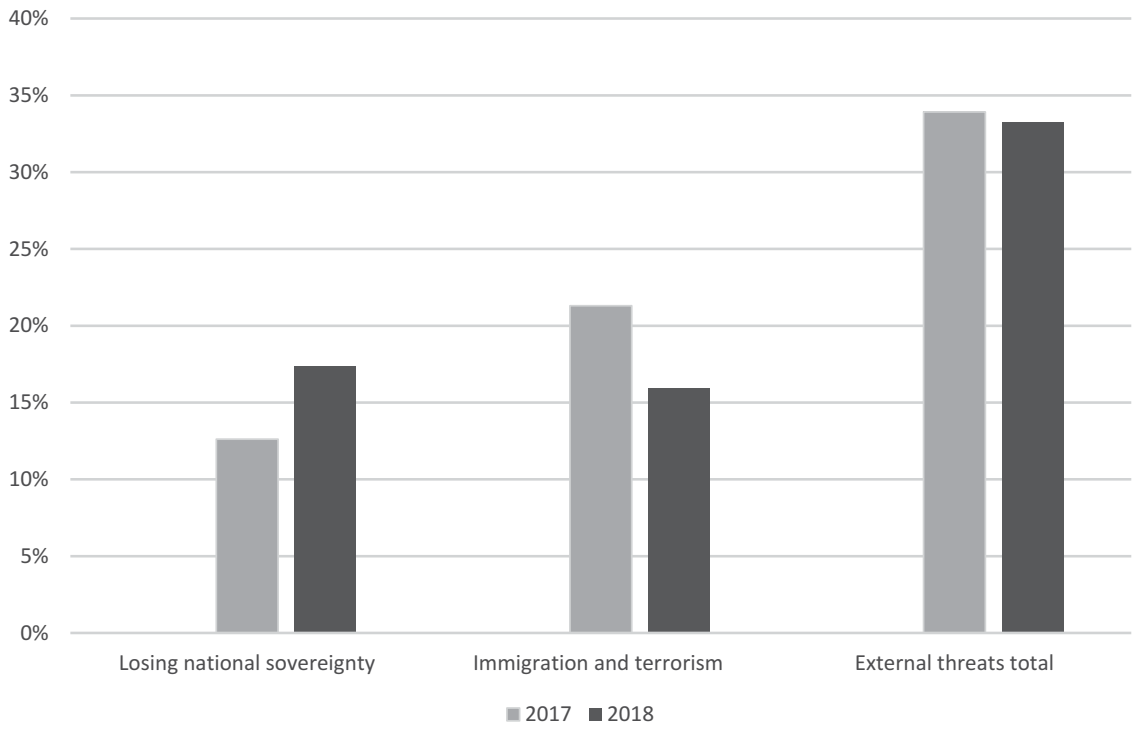

Figure 4.4 The prevalence of the perception of immigration, terrorism, and the loss of national sovereignty as the main threats for Hungary, 2017-2018, percentage of the total of selected items 22

Source: MTA Cooperation of Excellences, Mobility Research Center project, own calculations.

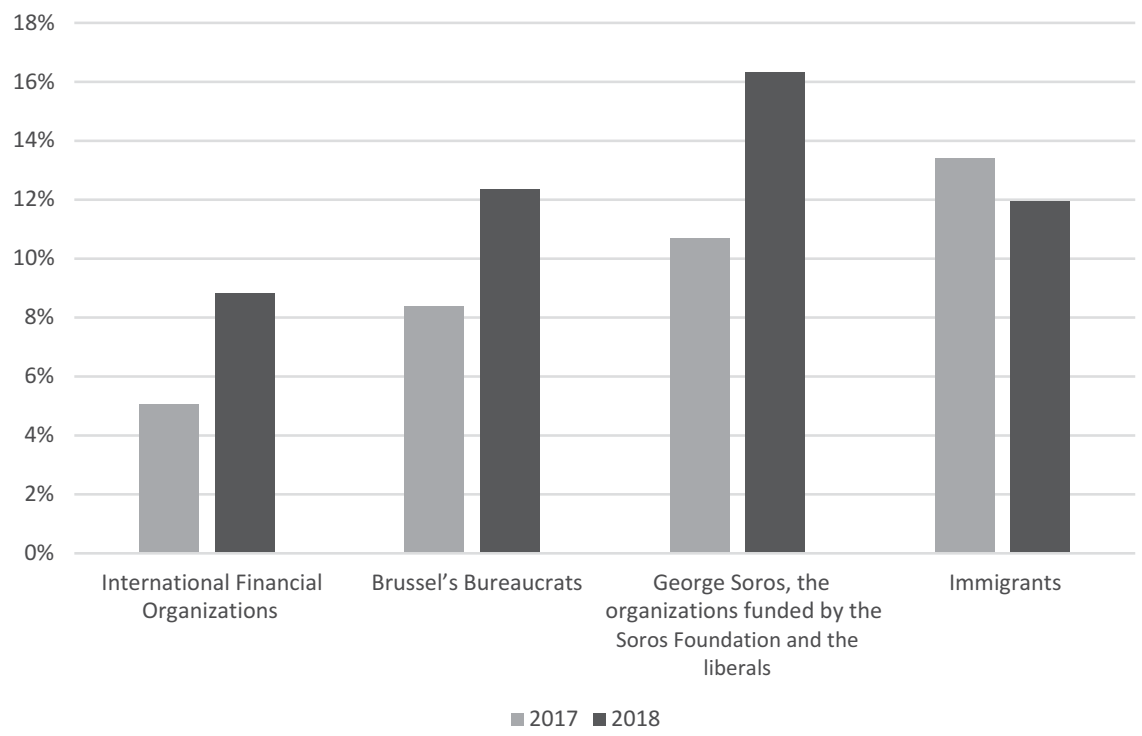

Figure 4.5 The extent to which respondents hold international actors responsible for the main threats for Hungary, 2017-2018, percentage of the total of selected items

Source: MTA Cooperation of Excellences, Mobility Research Center project, own calculations. 
sovereignty and immigration) are the most important threats and they hold international agents responsible for them, the opposition feels that the threats caused by the ruling elite - the demolition of democratic institutions and state level corruption, are the most important threats. Naturally, the main cause of these threats is the Orbán government (Gerő \& Szabó, 2017; Szabó \& Gerő, 2019). The opinion of respondents positioning themselves in the 'center' are usually in between those of the two groups with stronger political affiliation (Figure 4.6).

As Figure 4.1 already showed, since 2002, Hungarian society has been more xenophobe than other European countries. However, if we focus on the more recent changes represented in Figure 4.1, we find that the Hungarian results deviate from all countries - even from those where the level of rejection has increased - i.e. the prevalence of the Rejection Index was significantly faster. ${ }^{24}$

Moreover, unlike in other European countries, in Hungary there is no difference in the level of xenophobic attitudes between the various social groups (Figure 4.4).

While in Portugal, Austria, and the UK certain social groups exhibit significantly higher or lower levels of rejection of migrants, in Hungary, there is no deviation from the high level of the national average of rejection. We

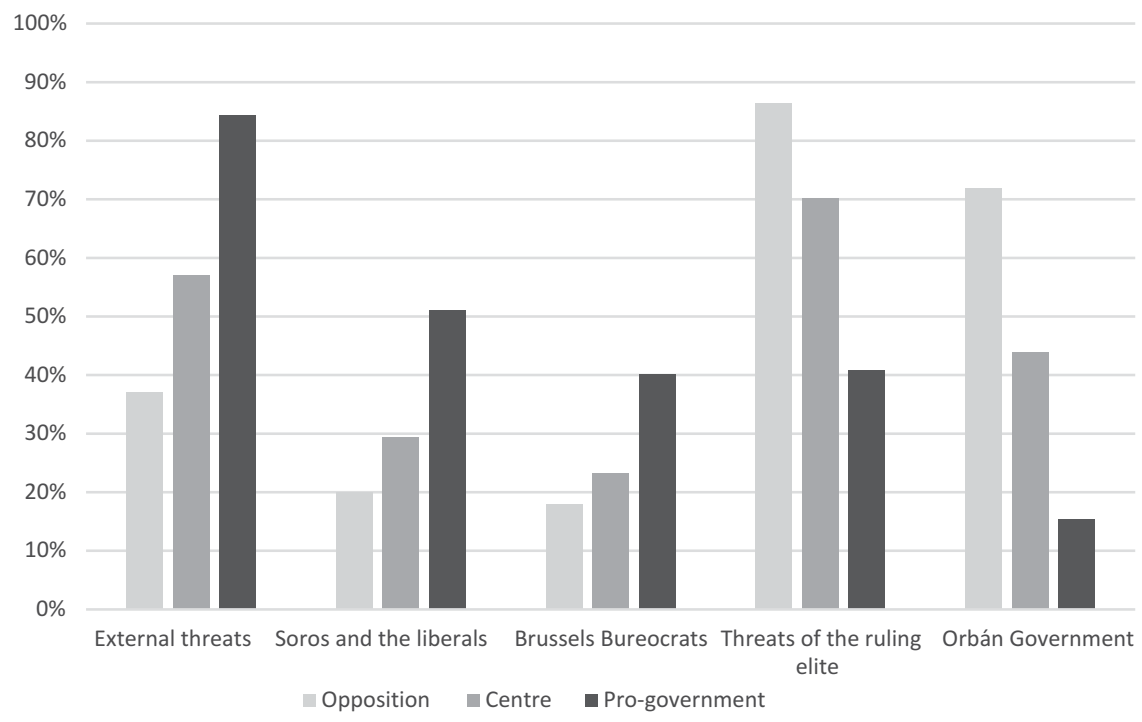

Figure 4.6 Perceived threats and the actors/groups held as responsible by political affiliation. Percentage of those who mentioned external threats (immigration and terrorism and losing national sovereignty) or threats of the ruling elite (state level corruption, demolition of democratic institutions), 2018

Source: MTA Cooperation of Excellences, Mobility Research Center project own calculation. 


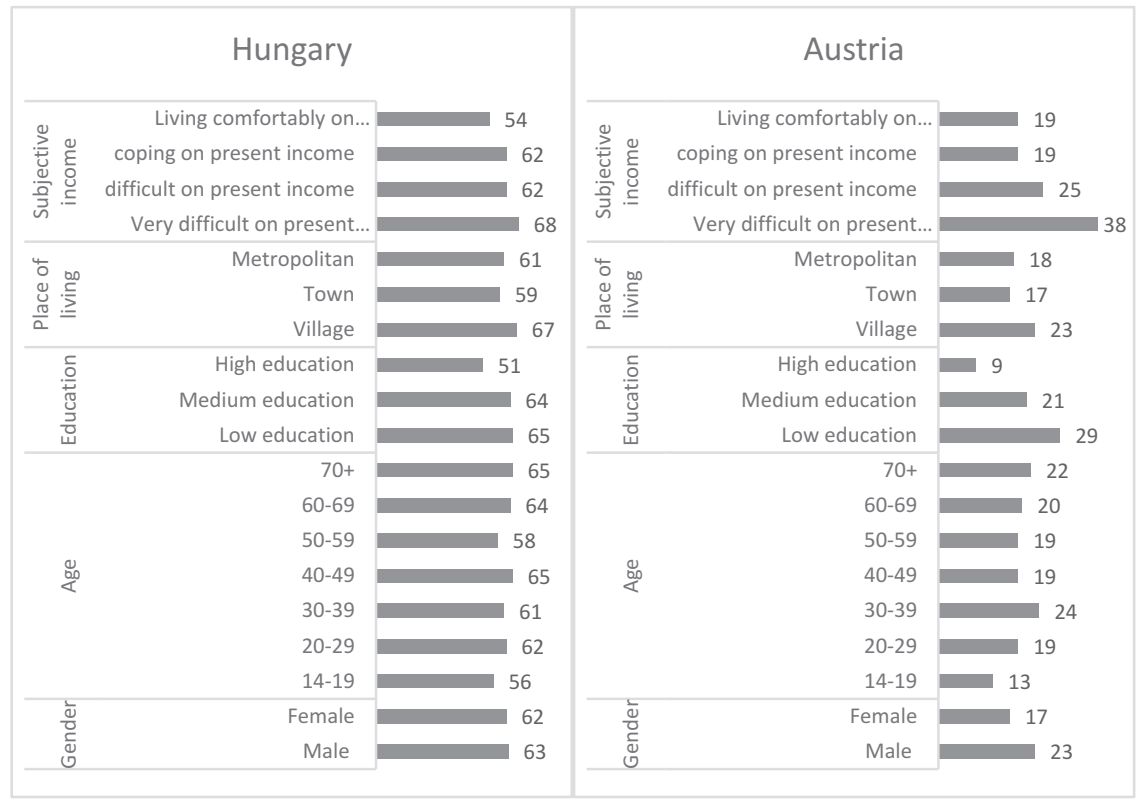

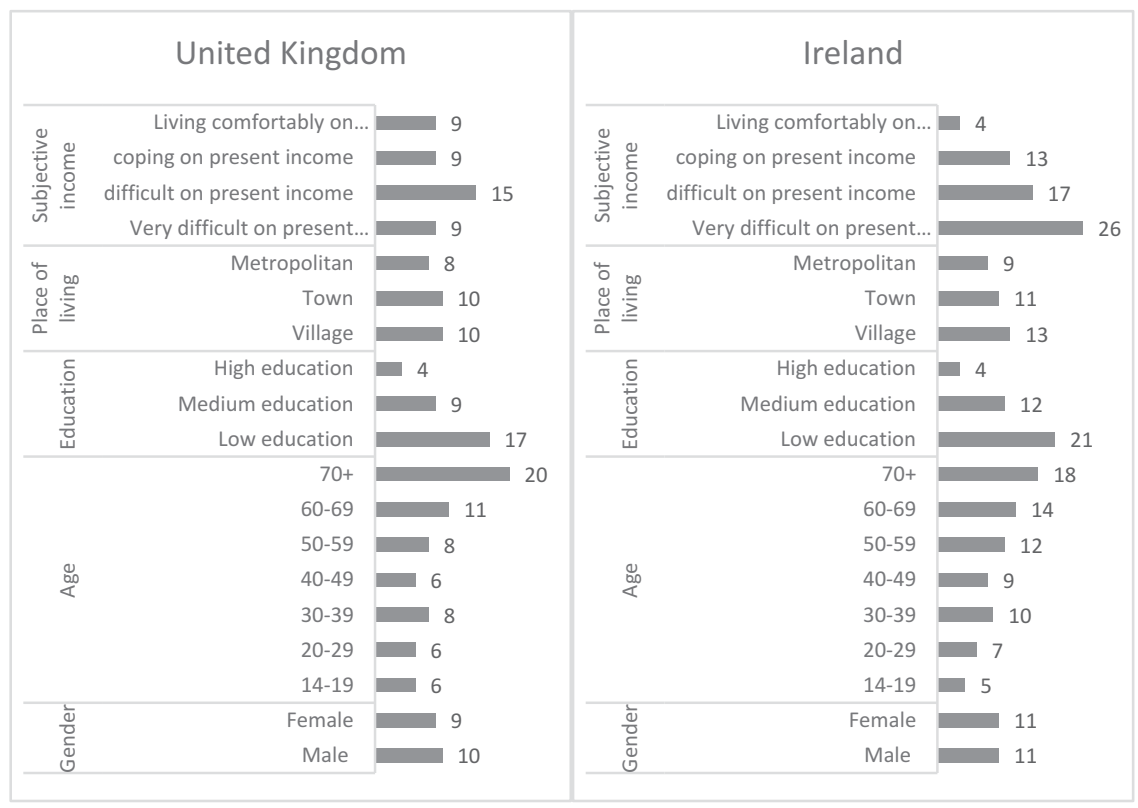

Figure 4.7 Rejection Index by demographic groups in four countries in 2016/2017 Source: Our design, based on Messing-Ságvári 2019. 
consider such uniformity (i.e. the lack of social group specific deviations) to be a result of MPB, since only intense brain-washing can create a situation where the same proportion of all parts of a complex society answers the questionnaire similarly.

We conclude, therefore, that even in the short run, the MPB 1) made the Hungarian society extremely xenophobic, and 2) successfully streamlined intolerant thinking of the entire society into an equally non-thinking formless mass. However, it is important to point out that we have been experiencing a twofold process: the unification of opinions regarding immigration on the one hand, and the simultaneous polarization of opinions about the importance of issues and enemies on the other.

\section{The long-term consequences of the success of the MPB}

In principle, the aim of consultations, information campaigns, and other tools applied in the political process is to help politicization, which, according to de Wilde (2011), includes a growing salience of issues, polarization of opinions and the pool of actors involved in the decision-making processes (social movements, experts, etc.). However, as Bognár et al. (2019) argue, though the Hungarian case might be seen as a successful case for politicization at first sight, this is hardly the occurrence - although immigration, as the core issue, became extremely salient, the polarization of opinions was reduced to duality. This type of polarization leads to the creation of mental borders between social groups, making public discussion impossible. Also, although the audience involved in the decisionmaking processes seems to be larger than before, the consequence of the national consultations and information campaigns is the exclusion of mediating actors and experts, and consequently, of alternative opinions from the debates (Bernáth \& Messing 2015).

We assume, therefore, that the biased politization process based on the success of the MPB, in the long run, serves the de-democratization processes of Hungary, which have gained much attention in recent years (Bogaards 2018; Bozóki \& Hegedủs 2018; Cianetti et al. 2018; Freedom House 2018). Although this literature focuses on the regulation and the state of democratic institutions, we argue that the de-democratization of the country is a result of the efforts to secure popular support and to disarm the challengers. As these efforts are manifested in techniques preventing the possibility of any critical attempts, and as the regime placed emphasis on these techniques, it became more and more radical in the sense of decomposing democratic institutions.

Thus, we argue, that 'de-democratization' is best understood when we focus on the way in which governments fight for popular support and legitimacy sanctioned by the masses. We argue that when the main tool of gaining this support is the Moral Panic Button, the result is not only increasing popular support, but the creation of different realities for the 
supporters and non-supporters of the regime. This divided reality draws boundaries between social groups and gives birth to harsh in-group outgroup conflicts. In such a situation, the government's only option is to maintain its support to further this process, which leads to the increasing control over the public sphere and the demolition of democratic institutions. In the constant fight to 'save the nation,' the destruction of democratic institutions appears as a necessary means.

This process fits the ongoing debate on hybrid regimes. According to Diamond (2002), until the second half of the twentieth century, the decision whether a regime was autocratic or democratic was easier, since, autocracies applied obvious forms of oppression to their opposition. In the last decades, however, the number of autocratic regimes that apply some democratic elements has been growing. They hold elections allowing limited competition, consequently allowing the existence of an opposition and non-state-controlled organizations and press. As they apply the scenery of a democracy, they claim the title as well, although it is quite clear that most of these regimes are far from being democratic - elections are hardly free and fair, the conditions of a real electoral competition are missing, most of the press is state-controlled through state ownership or by other means, and individual freedoms are limited.

Zakaria's (1997) concept of illiberal democracies also connects the rise of regimes with elections (democracies) and disrespecting constitutionalism (liberalism) with the second half of the twentieth century. Zakaria claims that only the West understands democracy as a system requiring more than competitive elections. Other parts of the world equal democracy with the existence of competitive elections, which are not necessarily accompanied by the respect of constitutionalism, the rule of law or respect for individual freedoms (Zakaria 1997).

Although there is much discussion about the existence of semi-democratic, hybrid regimes, illiberal or defective democracies, most of this scholarship is optimistic in the sense that they interpret the appearance of these regimes as a move from authoritarianism towards democracy. Even when the weaknesses of new democracies are discussed, they are attributed to the youth of these regimes, arguing that new democracies cannot be fully democratic in all examined aspects immediately, as they need to develop (Bogaards 2018).

Many of these scholars argue, however, that in the last years, the reversal of democratic transitions can be observed. In this reversal, it seems, Hungary plays a leading role (Csillag \& Szelényi 2015; Kornai 2015; Bogaards 2018; Bozóki \& Hegedüs 2018; Cianetti et al. 2018).

However, even in these attempts, scholars mostly try to describe how the regimes look, without explaining how governments are able to exploit the existing value system and the dissatisfaction with political institutions, and how they are able to transform social structures and institutions to support their attempts to maintain their power. 
Therefore, to explain the process of de-democratization, we have to pay attention to the use of political communication and the media as well, and in particular, to the technology of the MPB. Through the centralization of the media, and by applying national consultations and billboard campaigns, the government initiated a series of moral panics through which their preferred reality is presented.

As to the long-term impact of the MPB on the value system of the Hungarian society, if we accept solidarity as a basic European value, and the ability to think politically as a premise of a democratic society, then we see the MPB as a threat to the European value system. Even more so, since there are signs that the Hungarian technology appears to be transferred to other countries, in some cases directly (Macedonia, Slovenia), and in other cases, less directly (Poland). Therefore, the MPB Hungarian specialist think tank recently established a subsidiary in London, as an inheritor of the infamous Finkelstein emporium (see Balogh 2019).

In the long run, MPB seems to have the same role as New Speak has in Orwell's anti-utopian Oceania (Lexico Dictionaries n.d.), and the resulting society might also be similar - a brainwashed and dumb mass society without any communication skills, unable to form political opinion, and only sensitive to centrally initiated values.

\section{Notes}

1 This chapter is supported by the CEASEVAL project. Grant no. 770037, http:// ceaseval.eu/

2 All translations into English, except for those labelled otherwise, are ours.

3 The experiment was destined for success, partly because migration is a perfect theme for moral panic generation, and partly because previous research proved that the Hungarian population (compared to other EU countries) is very xenophobic (see Figure 4.1).

4 The Norwegian Civil Fund is a small part of the grants provided by Norway in compensation for accessing the Common Market without EU membership. Most of the grants are distributed through state organizations, except for the Civil Fund which is aimed at helping civil society and distributed by civil society organizations, independently from the state.

5 These attempts to label civil society organizations as foreign-funded organizations are very similar to those of other governments, e.g. Israel or Russia.

6 Every year during a mass celebration of the greatness and unity of the Hungarian nation, Orbán holds a visionary speech at a youth camp in a small city in Transylvania (Romania). In these speeches, he defines the core ideology and often the direction of his politics for the next year. The speech receives great attention each year.

7 Orbán Viktor's speech, 'The era of the work-based state is approaching,' translated by (Kopper et al. 2017: 117).

8 Other countries had lower level of xenophobia during the entire period, and/or a decreasing trend after 2015 (Messing \& Ságvári 2019: 20-22; Figures 12, 13, 14).

9 Since the figure in Messing \& Ságvári (2019: 25) is calculated from the freely available dataset of the European Social Survey, we re-calculated the data and designed our own figure (European Social Survey Cumulative file ESS 1-8 2018). 
10 Bernáth \& Messing (2015) point out that Fidesz borrowed the criminalization and security frames of JOBBIK, a radical right-wing party, while Bocskor (2018) reminds us, that the first campaign revived the labor-threat (as immigrants will take away Hungarians jobs) applied by the socialist-liberal government in 2004, as an argument against providing citizenship to Hungarians living in the surrounding countries.

11 1. National consultation on migration and terrorism, 2. Migration and terrorism - information campaign. 3. 'We don't want illegal immigrants!' - information campaign, 4. 'Let's send a message to Brussels!' - information campaign, 5. 'Did you know (...)?' - information campaign, 6. 'One Minute News' - UEFA Euro 2016, 7. 'One Minute News' - Olympic Games 2016, 8. Quota referendum and information campaign, 9. National consultation 'Stop Brussels,' 10. 'Don't let Soros have the last laugh!' - information campaign, 11. National consultation ,The Soros Plan,' 12. 'Stop Soros' - information campaign, 13. Parliamentary election 2018, 14. Anti-UN - i. c., 15. National consultation on family protection, 16. 'Soros-Juncker' EU election information campaign, 17. EU election

12 We usually do not treat migration-related news as a separate act of MPB but we treated the 'One minute news' television campaigns during the UEFA Cup and Olympic games as unique pressings of $\mathrm{MPB}$, since the overwhelming part of these news focused on migration and terror, and their messages were always very negative.

13 The questionnaires of National Consultations are sent out to every household in Hungary. The translations of the questions are freely available on the homepage of the Hungarian government, (see Prime Minister's Office 2015)

14 Not to mention that the combination of two elements in a single question is forbidden in survey research.

15 In 2018, the European Citizen's Consultation took place in 26 countries of the EU. The form and scale of the consultations varied from country to country, however, they always involved citizens' meetings and face to face communication (Butcher \& Pronckut $\otimes 2019$ ). Hungary was among the last countries to join the Consultation and its form was a chain of forums held by government officials (Stratulat \& Butcher 2018). The result of the forums was, according to the news reports, that Hungarians are committed to a Europe of nations, their priority is security and they do not want to live in an open society (see 'A magyarok nem akarnak nyílt társadalmat' 2018).

16 'If you come to Hungary you must not take Hungarians' jobs away from them!'; 'If you come to Hungary you must respect our culture!'; 'If you come to Hungary you must respect our laws!' Translation found in the Parliamentary question submitted by István Újhelyi, member of the European Parliament (Újhelyi 2015)

17 'The terror attack in Paris was carried out by immigrants,' ' 1 million immigrants are headed toward Europe, only from Libya!'

18 'Do you want the European Union to prescribe the mandatory settlement of nonHungarian citizens in Hungary, even without the consent of Parliament?'

19 The most likely cause of this loss of popularity was that after winning the election earlier in 2014, the government decided to increase the tax on Internet use (Szombati 2015).

20 The data is available at Sik 2019.

21 The surveys were conducted as part of the research project 'Integration and disintegration processes in Hungary' (2017, grant no. NKFIH 108836), and the MTA Cooperation of Excellences, Mobility Research Center project of the Centre for Social Sciences, Hungarian Academy of Sciences (2018).

The respondents could choose the three most important dangers threatening Hungary out of ten items. These items were grouped as 1) external threats (the dangers of immigration and terrorism, and the loss of Hungarian national 
sovereignty), 2) dangers posed by the ruling elite (de-democratization processes and corruption), and 3) threats posed by dissatisfactory public policies (social inequalities, education, and healthcare). Figures 4.4 and 4.5 represent only the external threats and international actors/groups. The surveys were conducted between March and April 2017, and between September and November 2018.

22 Since the question was a multiple-choice question, the number of possible choices is not equal to the number of respondents (2000 and 2700), but it is three times larger. The figures represent the choices compared to this total number, not to the number of respondents.

23 See also Messing \& Ságvári (2019), in which the authors show that perceptions about immigration are highly dependent on political affiliation.

24 Other analyses described the same trends in Hungary. For example, Barna \& Koltai (2019) compare the 6th and 8th waves of ESS's Hungarian data from 2012 and 2017, and find that the proportion of the population who would not allow anyone to enter the country grew significantly until 2017. The most significant growth was found among sympathizers of the governing party. Simonovits (2016) found similar results: the ratio of people rejecting asylum seekers was already high (around $40 \%$ ) in 2014, but became even higher (53\%) in 2016 and the proportion of the respondents that would accept all asylum seekers decreased from 10 to $1 \%$.

\section{References}

'A magyarok nem akarnak nyílt társadalmat' (2018). Hír TV. Available at: https:// hirtv.hu/ahirtvhirei/a-magyarok-nem-akarnak-nyilt-tarsadalmat-2471594

Bajomi-Lázár, P. (2013). 'The party colonisation of the media: The case of Hungary,' East European Politics and Societies 27(1), pp. 69-89.

Balogh, E. S. (2019). 'The genesis of Orbán's anti-Soros campaign,' Hungarian Spectrum 16 January. Available at: https:/hungarianspectrum.org/2019/01/15/the-genesi s-of-orbans-anti-soros-campaign/

Barlai, M. \& Sik, E. (2017). 'A Hungarian trademark (a "Hungarikum”): The Moral Panic Button 12,' The Migrant Crisis: European Perspectives and National Discourses, 13, p. 147.

Barna, I. \& Koltai, J. (2019). 'Attitude changes towards immigrants in the turbulent years of the "migrant crisis" and anti-immigrant campaign in Hungary,' Intersections. East European Journal of Society and Politics, 5(1).

Bayer, J. (2011). 'Az új médiatörvény sajtószabadságot korlátozó rendelkezései,' Médiakutató,pp.1-8.

Bernát, A. et al. (2015). Attitudes Towards Refugees, Asylum Seekers and Migrants. Budapest: TÁRKI. Available at: www.academia.edu/19899123/ATTITUDES_ TOWARDS_REFUGEES_ASYLUM_SEEKERS_AND_MIGRANTS

Bernáth, G. \& Messing, V. (2015). 'Bedarálva: A menekültekkel kapcsolatos kormányzati kampány és a t\Hole független megszólalás terepei,' Médiakutató 16(4), pp. 7-17.

Bocskor, Á. (2018). 'Anti-immigration discourses in Hungary during the "Crisis" year: The Orbán government's "National Consultation” campaign of 2015,' Sociology, 52(3), pp. 551-568.

Bogaards, M. (2018). 'De-democratization in Hungary: Diffusely defective democracy,' Democratization, 25(8), pp. 1481-1499.

Bognár, É., Sik, E. \& Surányi, R. (2018) 'The case of Hungary - de Wilde goes wild,' CEASEVAL report. Available at: http://ceaseval.eu/publications/08_BognarSik_ Suranyi_The_case_of_Hungary.pdf 
Bozóki, A. \& Hegedűs, D. (2018). 'An externally constrained hybrid regime: Hungary in the European Union,' Democratization, pp. 1-17.

Bugaric, B. (2016). 'Protecting democracy inside the EU: On Article 7 TEU and the Hungarian turn to authoritarianism,' in CLOSA, Reinforcing Rule of Law Oversight in the European Union. Cambridge: Cambridge University Press, Forthcoming.

Butcher, P. \& Pronckutè, S. (2019). 'European citizens' consultations: Consultation begins at home,' European View, 18(1), pp. 80-88. doi:doi:10.1177/1781685819847637

Cianetti, L., Dawson, J. \& Hanley, S. (2018). Rethinking 'Democratic Backsliding' in Central and Eastern Europe - Looking beyond Hungary and Poland. Oxon: Routledge.

Cohen, S. (1972). Folk Devils and Moral Panics. London: MacGibbon \& Kee.

Cohen, S. (2011) 'Moral panics as cultural politics: Introduction to the third edition,' in Cohen, S. (ed.) Folk Devils and Moral Panics. New York: Routledge, pp. vi-xliv.

Csillag, T. \& Szelényi, I. (2015). 'Drifting from liberal democracy: Traditionalist/neoconservative ideology of managed illiberal democratic capitalism in post-communist Europe,' East European Journal of Society and Politics, 1(1), pp. 18-48.

De Wilde, P. (2011). 'No polity for old politics? A framework for analyzing the politicization of European integration,' Journal of European Integration, 33(5), pp. 559575. doi:doi:10.1080/07036337.2010.546849

Diamond, L. J. (2002) 'Thinking about hybrid regimes,' Journal of Democracy, 13(2), pp. 21-35. doi:doi:10.1353/jod.2002.0025

EKINT (2016). Üzenjük Magyarországnak: Tanulmány. Budapest: Friedrich Ebert Stiftung. European Social Survey Cumulative File, ESS 1-8 (2018). Data file edition 1.0. NSD Norwegian Centre for Research Data, Norway - Data Archive and distributor of ESS data for ESS ERIC. doi: doi:10.21338/NSD-ESS-CUMULATIVE

Freedom House (2018). Freedom in the World 2018: Democracy in Crisis. Available at: https://freedomhouse.org/report/freedom-world/freedom-world-2018

Hajdu G. (2014). Válság és társadalmi innovációk survey. Available at: http://opena rchive.tk.mta.hu/384/10/peripato2014_gyorsjelentes-384.pdf

Gerő, M. \& Szabó, A. (2017). 'A társadalom politikai integrációja. A politikai értékcsoportok,' in Társadalmiintegráció (ed.) Az egyenlótlenségek, az együttmúködés, az újraelosztás és a hatalom szerkezete a magyar társadalomban. Budapest/ Szeged: MTA Társadalomtudományi Kutatóközpont/Belvedere Meridionale, pp. 117-153.

Goode, E. \& Ben-Yehuda, N. (1994). 'Moral panics: Culture, politics, and social construction,' Annual review of sociology, 20(1), pp. 149-171.

Index (2015). 'Orbán: Gazdasági bevándorlóknak nem adunk menedéket,' Index, 11 January. Available at: https://index.hu/belfold/2015/01/11/orban_gazdasagi_beva ndorloknak_nem_adunk_menedeket/

Kalmar, I. (2018). "The battlefield is in Brussels": Islamophobia in the Visegrád Four in its global context,' Patterns of Prejudice, 52(5), pp. 406-419. doi:10.1080/0031322 X.2018.1512473

Kende P. (1996). 'A “liberalizmus” mint szitokszó | Beszélő,' Beszélo", 1(1). Available at: http://beszelo.c3.hu/cikkek/a-\%E2\%80\%9Eliberalizmus\%E2\%80\%9D-mint-szitokszo

Kopper, Á., Susánszky, P., Tóth, G., \& Gerő, M. (2017). 'Creating suspicion and vigilance,' Intersections 3(3). doi:doi:10.17356/ieejsp.v3i3.366

Kornai, J. (2015). 'Hungary's U-turn: Retreating from democracy,' Journal of Democracy, 26(3), pp. 34-48.

Kovách, I., Gerő, M., Hajdu G., Huszár, Á., \& Szabó, A. (2018). MTA Cooperation of Excellences, Mobility Research Center project, KEP 1. Dataset. Budapest: MTA Centre For Social Sciences. 
Lázár, D. \& Sik, E. (2019). 'Ez a szupermanipuláció az igazságra törekvés értékét is eltüntetheti,' 24.hu, 31 May. Available at: https://24.hu/belfold/2019/05/31/sik-en dre-moralis-panik-propaganda/

Lexico Dictionaries (n. d.) 'Definition of newspeak in English by Lexico Dictionaries,' in Lexico Dictionaries | English. Available at: www.lexico.com/en/definition/newspeak

Messing, V. \& Ságvári, B. (2019). Still Divided but More Open. Budapest: Friedrich Ebert Stiftung.

Népszava (2015) Orbán Viktor's full statement about the terror attack in Paris. Available at: https://nepszava.hu/1044829_orban-viktor-teljes-nyilatkozata-a-pa rizsi-merenyletrol

Péterfi, F. (2016) 'Súlyok és ellensúlyok aránytalansága: A civil társadalom esélyei az egyensúlyát vesztett és bizalomhiányos társadalomban,' in A civilek hatalma - A politikai tér visszafoglalása. Budapest: Noran Libro, pp. 187-197.

Polyák, G. (2019). 'Media in Hungary: Three pillars of an illiberal democracy,' in Public Service Broadcasting and Media Systems in Troubled European Democracies. Springer, pp. 279-303.

Prime Minister's Office (2015). National Consultation on Immigration and Terrorism. Available at: www.kormany.hu/download/9/a3/50000/nemzetikonzultacio_mmkorr nel.docx

Rovó, S. \& Dull, A. (2016). Lehet hinni a kormány új menekültplakátjainak? Available at: http://index.hu/belfold/2016/07/20/lehet_hinni_a_kormany_uj_menekultplakatjainak/

Sik, E. (2016). 'Egy hungarikum: a morálispánik-gomb,' Mozgó világ, 42(10), pp. 67-80.

Sik, E. (2019). Választásra jogosultak. Available at: https://docs.google.com/sprea dsheets/d/1eitltXmNIU4tHgrYiaQPWPHaG4tN0xVSZO4w_k0mVyA/edit?usp= embed_facebook

Simonovits, B. (2016). 'Migration-related fear and scapegoating: Comparative approach in the Visegrad countries,' in Simonovits, B. \& Bernát, A. (eds) The Social Aspects of the 2015 Migration Crisis in Hungary. Budapest: TÁRKI, pp. 32-40.

Stratulat, C. \& Butcher, P. (2018) The European Citizens' Consultations: Evaluation Report. D/2018/10.825/1. European Policy Centre. Available at: www.epc.eu/docum ents/uploads/pub_8839_19_11_ecc_web.pdf?doc_id=2065

Szabó, A. \& Gerő, M. (2019). A magyar társadalom és a politika, 2019: A magyar társadalom politikai gondolkodásmódja, politikai integráltsága és részvétele. Budapest: MTA Társadalomtudományi Kutatóközpont. Available at: https://tk.mta.hu/uploa ds/files/2019/mob_pol2019_online.pdf

Szombati, K. (2015). Why Hungarian Voters are Turning Away from Fidesz and Towards Jobbik. Heinrich-Böll-Stiftung. Available at: www.boell.de/en/2015/06/02/why-hunga rian-voters-are-turning-away-fidesz-and-towards-jobbik

Torma, J. (2016). 'A norvég-ügy-Civil szervezetek elleni kormányzati támadássorozat Magyarországon (2013 és 2016),' in Attila, A. (ed.) A civilek hatalma - a politkai tér visszafoglalása, Budapest: Noran Libro, pp. 266-282.

Újhelyi, I. (2015). Who Might Take Away Hungarians' Jobs?European Parliament. Available at: www.europarl.europa.eu/doceo/document/E-8-2015-009641_EN.html

Zakaria, F. (1997). 'The rise of illiberal democracy,' Foreign Affairs 76(6), p. 22-43. 


\section{Abolishing asylum and violating the human rights of refugees. Why is it tolerated?}

The case of Hungary in the EU

Felix Bender

\section{Introduction}

And at this point, Dear Friends, I must also say a few words about the dispute between Western and Central Europe. It seems that the courses of development of these two parts of Europe have diverged.... The great old European nations in Western Europe have become immigrant countries. Day by day their cultural foundations are being transformed, the population raised in a Christian culture is declining, and the major cities are undergoing Islamization.... We have prevented are the last country in Latin - or Western - Christianity. We are standing firm.

(Orbán 2018a)

The basic right of asylum applies to all persons persecuted on political grounds. We can be proud of the humanity of our constitution. It reveals itself especially in this article. We also provide protection to those who flee to us from war zones. They, too, are owed protection.

(Merkel 2015, own translation)

The two statements below could not differ more.

Contemporary Europe is witnessing a rift. On the one hand, core EU member states, such as Germany, rhetorically affirm their fidelity towards the institution of asylum. 'Persons persecuted on political grounds shall have the right of asylum,' reads Article 16a of the Basic Law (Basic Law for the Federal Republic of Germany, 1949). The German government has been lauded for upholding the normative principle that lies at the core of this article in its response to the 'refugee crisis' of 2015 (Betts 2015; Ignatieff 2017). It has been seen as defending the principle that asylum must remain a fundamental right available to all who apply for it.

On the other hand, we are witnessing the emergence of a different norm: a norm of closure, celebrated by several countries at the periphery of the European Union, but most notably by Hungary. Rhetoric, such as the 
above, underlines the construction of walls, open hostility towards foreigners, and violence against them.

It would be too easy to be satisfied with an answer to the question of how this rift came about. Instead, we must seek the answer to the question: why does it remain? This chapter seeks to answer this question. It seeks to explain why we are witnessing so little resistance against the abuse of human rights and the de-facto abolition of the institution of asylum in Hungary by states that seemingly cherish the normative principle underlying the right to seek asylum. In other words, it aims to explain how these two distinct positions relate to each other.

Before answering the question posed above, we need to elaborate on the definition of the rift itself. What does the norm of closure, celebrated by Hungary's politicians, entail? How does it differ from a fundamental fidelity towards the institution of asylum? Only after we answer these questions, can we try to explain why the rift persists. The answer this chapter gives is simple. The rift remains, because these seemingly contrary positions necessitate each other. Core EU countries, such as Germany, can only position themselves as states that uphold and defend the principle underlying asylum, if countries at the periphery of the EU deny asylum seekers access to their territories. Conversely, core EU countries condone the treatment of refugees at the EU periphery, even if it implies human rights abuses and the de facto abolition of the institution of asylum. The result is a 'division of labor.' Core EU countries may portray themselves as morally untainted. They enshrine and uphold the fundamental right of asylum, while countries such as Hungary may reap the political fruits of a norm of closure, as long as they keep refugees at bay. In this context, it seems easy to condemn the latter. And we should. What we might learn, however, is that the former are not as morally untainted as we might have thought.

I suggest to first look at what the norm of closure entails. Although we can observe different countries testing the limits of such a norm, none has done so to the same degree as Hungary. Therefore, in the first section of this chapter, I explain what makes the norm of closure special and what it entails. I show that said norm entails the abolition of the institution of asylum and what this means for the treatment of refugees. The second part of the chapter concerns the question of why the abolition of the institution of asylum and the human rights abuses of refugees at the EU periphery are condoned by states at the territorial core of the EU. I ask why this is the case even though states such as Germany seemingly cherish the normative principle underlying the right of asylum. It should be noted that this chapter is mainly concerned with the politics and policies regarding refugees after the so-called refugee crisis of 2015. I do not discuss the situation in Hungary and Germany during the events of the 'long summer of migration.' ${ }^{1}$ Rather, I am interested in the events and the politics that ensued. 


\section{Dominating refugees: the abolition of the institution of asylum in Hungary}

\section{Abolishing asylum}

In early 2015, the rift was nothing more than a crack. The Hungarian state possessed a somewhat functioning asylum system. ${ }^{2}$ Its politicians were, by and large, not very interested in the topic of migration. This changed as the year progressed. The reasons for this change are not very clear. It may have been related to mounting dissatisfaction with government policies - the government had just proposed a hugely unpopular tax on internet use leading to politicians searching for alternative topics to reel in the public. Or it may have had to do with the realization of Hungarian politicians that fighting a foreign enemy (real or imagined) allows for the creation of a partyoverarching 'We' - a national identity to rally behind (Nagy 2016). Whatever the reasons for the change might have been, we are not interested in the origins of the policies that were about to follow, but rather in their effects. Thus, let us focus on the latter.

Shortly after hundreds of thousands of refugees had made their way across what they regarded as a country of transit up until September 2015, Hungary decided to put a stop to the movement of refugees. In the summer of 2015, it announced that it would build a fence along its entire $175 \mathrm{~km}-$ long border with Serbia, aimed at keeping refugees at bay. The Minister heading the Hungarian Prime Minister's Office, János Lázár, justified the construction of the fence by referring to the necessity of orderly migration: 'we are conservative people; we insist that if you want to enter someone's house, you must knock first, rather than break down the wall' (2015). Yet, the fence did not establish orderly migration. It aimed to put a halt to migration altogether. It was the first step towards the abolition of a principally applied right to asylum. The creation of a physical barrier at the border with Serbia was only part of the construction of an order that sought to control the movement of refugees and aimed at detaining and deterring refugees. This order, aimed at the abolition of the institution of asylum, entails much more than just blocking the paths of refugees. It entails establishing control over refugees within the demarcation lines that we call the border. ${ }^{3}$ Both subject refugees to a regime of violence.

The construction of the fence was accompanied by the establishment of transit zones at the border, which function as barbed wire fenced detention centers, holding refugees until their refoulement. Moreover, it was accompanied by a bevy of laws, deteriorating the institution of asylum, and constructing a regime aimed at sealing the borders at any price.

The first wave of laws restructuring the order controlling refugees came into force on the day the border fence was officially completed: September 15,2015 . The new regulations aimed to criminalize the border crossings of refugees and make seeking asylum a criminal offense if not performed in 'the orderly way' the government foresaw. Refugees crossing anywhere at the 


\section{F. Bender}

border, and not at the newly established transit zones, would now be punished by a prison sentence of up to one year, expelled from the country, and banned from re-entry. Even stricter forms of punishment awaited those who damage the fence while crossing the border. This newly created offense could result in a prison sentence of up to three years. Between September 2015 and December 2016, this law resulted in 3,000 cases being brought before court (Binetti Armstrong 2018). Most of them ended in convictions. Of course, entering Hungarian territory anywhere but the transit zones could only be achieved through damaging the newly erected fence, which meant that anyone caught doing so would be liable to serve between one and three years in prison. The law serves as a potential blanket justification for denying those who cross the border at locations other than the designated spots and stands the right to seek asylum, of course, in blatant contradiction to international law (Hungarian Helsinki Committee 2015a).

The orderly way, according to the Hungarian Government, was for refugees to enter through the newly created transit zones either at the border with Serbia or Croatia. Yet, access to these transit zones was never unlimited. The transit zones, which were de facto detention centers consisting of container camps, surrounded by razor wire, and guarded by armed police, were never accessible to anyone who wanted to launch an asylum procedure. Since their establishment in 2015, the number of people admitted daily was steadily reduced by the Hungarian state from 30 to only two - one person per transit zone and per work-day (Hungarian Helsinki Committee 2018a). The transit zones themselves were established solely on Hungarian soil, leaving a stretch of land beyond these zones on Hungarian territory, too. This stretch of land between the zones and Serbian territory was aptly described by NGOs as a 'no man's land' (Hungarian Helsinki Committee 2016a; Binetti Armstrong 2018). The Hungarian state refused to assume responsibility for the refugees remaining in it, and the international organizations that sought to organize support for those stranded there had difficulties doing so, since they were not invited by the Hungarian state to distribute aid to refugees remaining on Hungarian soil. The order that the Hungarian state had established thus reached beyond the immediate barriers erected. Since admission was restricted and no procedure existed to determine who was to enter next, refugees were kept in limbo beyond the fence. At times, thousands camped in front of the transit zones without basic support, with thousands returning to Serbia to live in squalid conditions in a country without a functioning asylum system (Umek, Minca \& Šantić 2019). Thus, even though refugees had already entered Hungary and the state's international legal responsibilities were clear, their claims to enter asylum procedures were denied as a consequence of the new legislation (Hungarian Helsinki Committee 2016a; 2018e).

These legislative changes also had a profound impact on ordering the lives of the refugees who made it to the parts of the country in which the Hungarian state still claimed responsibility for administering asylum claims. They 
profoundly changed the asylum procedure, including admission criteria, application procedures, and access to effective remedies.

The legislative package introduced a number of additional countries as safe third countries. Once they enter the transit zones and after initial checks for competency according to the Dublin regulations, asylum seekers' applications must be checked for admissibility. The safe third country rule allowed for deeming applications inadmissible if the applicant had passed through and could have lodged an asylum application in a safe third country before having lodged an asylum procedure in Hungary. In 2015, Serbia was included on this list (cf. Hungarian Helsinki Committee 2015b; Binetti Armstrong 2018). This means that all asylum applications lodged by persons that have travelled through Serbia were ruled inadmissible from the outset unless refugees could provide evidence for being unsafe in Serbia. Since the vast majority of refugees travel through Serbia to reach Hungary, the regulation results in over $99 \%$ of the refugees applying for asylum in Hungary being automatically rejected (Hungarian Helsinki Committee 2015b). The decision on admissibility, according to the new law, is to be taken within eight days. Yet, in practice, decisions are often reached in less than one hour (Asylum Information Database 2017). After a negative decision, refugees are given only three days to disagree with it and prove why these 'safe third countries' are not safe in their individual cases. In many instances, however, refugees are given a prepared document to sign, stating their disagreement with the negative decision. This document serves as the basis for immediately rejecting such requests by the immigration office. This occurs without considering the refugee's statement and without the refugee being able to consult legal advisors. Following this decision, refugees are again given only three days to appeal it - not enough time to prepare for a court hearing. All in all, refugees are unable to legally challenge inadmissibility decisions effectively, which constitutes a violation of the right to an effective remedy (Asylum Information Database 2017). Consequently, they are then supposed to return to the relevant safe third country. Serbia, however, refuses to take back any refugees from Hungary. For refugees, this often means that following an inadmissibility decision, they are simply 'escorted' out of the transit zone. They still find themselves on Hungarian territory, but beyond the border fence and banned from re-entry for one or two years. The order that the Hungarian state imposes creates refugees that exist in orbit - they are not legally admitted to Hungary or to Serbia. What this means is a life in the shadows and for many this meant simply returning to the camps in Serbia, if one did not want to run the risk of re-entering Hungary elsewhere.

These are, of course, not the only changes made to the institutional structure regulating asylum procedures in Hungary. An order that aims to completely control the lives of refugees and to abolish the institution of asylum, cannot issue control over parts of this system. It must also encompass those attempting to defend the rights of refugees and the institution of asylum itself. 


\section{F. Bender}

A final shift towards the abolition of the right to asylum and, thus, the last brick in building a norm of closure came in 2018. In June, the Parliament passed a legislative package called 'Stop Soros' that effectively excluded civil society actors from asylum procedures. The laws threatened severe punishments, ranging from banishment from border areas to prison sentences, for those assisting asylum seekers legally or materially before their asylum status was confirmed (Hungarian Helsinki Committee 2018b). This served the purpose of reducing the probability of refugees to receive asylum. By restraining the observing function of civil society actors and their capabilities of intervening in asylum procedures, the state administration and court system were given a wider range of discretion in operating and deciding the outcome of such procedures. Refugees without legal assistance can be denied asylum more easily.

In the context of minimizing the role of civil society organizations and maximizing the discretionary power of administrative bodies and courts, the Hungarian government proceeded to add further significant restrictions to asylum procedures. In December 2018, the Parliament passed constitutional amendments that effectively replaced the safe third country rule with an article that is simultaneously less specific and more restrictive. ${ }^{4}$ The article replaces the idea of providing a list of countries, in which refugees are effectively able to seek asylum and are hence safe with a general clause that stipulates safety for refugees in any country in which they do not fear persecution. The difference between the two is significant. The new formulation offers asylum only to those who have entered Hungary directly from the state in which they fear persecution. Crossing any other state in which a fear of persecution cannot be demonstrated leads to the rejection of an asylum claim, even if seeking asylum in these states is not feasible.

These legal changes reverse both the interpretation of safety and the onus of proof. While asylum claims could formerly be rejected only if the safety of refugees could be demonstrated elsewhere, they can now be rejected on the grounds that they are not unsafe elsewhere. Therefore, one must no longer prove their safety, but merely a lack of persecution. This also places the onus of proof on the refugee. The state must no longer justify to refugees why they would be safe elsewhere. Instead, it is now up to the refugees themselves to justify why they would not be safe elsewhere.

The intimidation of and the control over all agents involved in the asylum process would not be complete without seizing control over the institutions that provide the final legal decisions over matters of asylum. To this end, the Hungarian government has stripped the Constitutional Court of the country of its powers in ruling on administrative cases. With the constitutional changes, a parallel high court, called the Administrative High Court, was introduced that assumed these responsibilities, including the authority to issue final rulings on asylum cases (amongst others) and with the power to issue interpretative guidance in applying the law to lower courts. The president of this newly founded court is elected by the Parliament (cf. Hungarian Helsinki 
Committee 2018c). The smooth translation of political programs into coherently interpreted case law should thereby be guaranteed. This includes the changes made to the asylum procedure. The affirmation of these changes and a coherent interpretation of lower courts in the application of the new laws should thereby also be guaranteed.

These legal changes amount to an institutional landscape of concentrated power over the lives of refugees. The structures that dominate them only mockingly resemble those of an asylum system that aims at protecting those seeking refuge from war and persecution, while hollowing out those rights. The state has encroached on all matters relating to asylum. It dominates the lives of refugees from the moment they attempt to enter Hungarian territory, curtailing their rights to access, fair legal representation, and a just procedural determination of their asylum claims. Structurally, the institution of asylum is dead in Hungary.

\section{Dominating refugees: human rights abuses}

Yet, we cannot stop here. The complete control over the lives of refugees has a profound impact on their well-being. To see how, we may turn to some of the extrajudicial forms of domination and their results in violating the human rights of refugees in Hungary.

For all those refugees that do not want to wait for an unspecified time and an unspecified chance of entering one of the transit zones, only one option exists: entering Hungarian territory elsewhere. This, however, is connected with severe physical dangers. In addition to the above-mentioned obstacle of surpassing a razor-wire reinforced fence and risking a prison sentence of up to three years if caught, refugees have been faced with yet another form of danger since 2016. A set of laws entered into force in July of that year, creating an $8 \mathrm{~km}$ stretch on the Hungarian side of the border fence within which refugees could be apprehended and pushed back to Serbia without launching an asylum application or following a deportation decision (Hungarian Helsinki Committee 2016b). In 2017, this initial stretch of land was extended to cover the entire territory of the country (Hungarian Helsinki Committee 2017a). These push-backs feature an extraordinary amount of violence. Refugees are fair game after they pass the border in this way. The institutional structures place unchecked power into the hands of the army and a specially established police force that bears the name 'border hunters.' The hunt for refugees, however, is not confined to those bearing the official insignia of the Hungarian state. Private vigilante groups in military garments patrol the border too - condoned by the Hungarian state. They search and seize refugees. Then, they wait for the police or the army. What happens in between is up to them. When the border police arrive, refugees are 'escorted' to the fence and are made to exit to Serbia. The whole process involves physical violence, such as beatings, intimidation with dogs and batons, destruction of property, and treatment demeaning of their human dignity. 
To grasp what such treatment implies and how it occurs, we may turn to the testimony of a refugee so apprehended on May 23, 2016. That his is not a unique treatment, but rather an expression of a systematic abuse of the human rights of refugees, is corroborated by numerous similar accounts of refugees being returned to Serbia (Human Rights Watch 2016a; Hungarian Helsinki Committee 2017b; Médecins Sans Frontieres 2017). In the company of eight other people, the Afghan man was forced to run back to the border fence. He describes what happened as follows:

We were tired but if we lagged behind, they would beat us with their batons to keep us going. They took us back to where we crossed the border and made us stop about 100 meters from the fence. About 30 police were gathered.... They wore dark blue uniforms, there was also one in grey. They told us to sit and put our heads in our hands and not lift our heads to look around. But I managed to see that they brought two big spray canisters from the cars. They started beating us with batons while we sat and stared at the ground. Then they told us to stand up and run up to the fence and they kept beating us as we were running. We came about ten meters from the fence and saw a small hole, full of razor-wire and sharp edges in three layers.

They brought plastic cuffs and tied our hands in front of our bodies. I was the first in line and all of a sudden, a police officer came and sprayed my face. I couldn't see as he made me crawl through the razor-wire, so I cut my leg and hands badly. After that, I was inside the layers of the fence when he started kicking the fence to make the razor injure me. He then kept kicking my butt to make me crawl faster through the fence. My eyes were full of tears and my hands cuffed in front of me. They swore and laughed at me during the whole time.

(Human Rights Watch 2016b)

In 2017 alone, almost 10,000 of such pushbacks have occurred. Over 10,000 refugees attempted to cross the border but were detected and blocked by the police (Hungarian Helsinki Committee 2018d).

The violation of the human rights of refugees is a direct consequence of an institutional landscape that concentrates power and abolishes checks and balances. In such an environment, extrajudicial forms of domination of refugees may thrive without punishment. The climate, in which such forms of extrajudicial violence occur, is one of hostility against refugees and one that arguably supports the creation and the operations of private vigilante groups and violence against refugees. Such climate is created directly on behalf of the Hungarian government - both through a number of public campaigns and a media landscape that nearly exclusively belongs to its supporters. The public campaign vilifying refugees spans a timeline from 2015 until today. Numerous posters were placed throughout the country, instructing locals on the dangers of terrorism, the threat to their jobs and 
their culture that refugees pose. Leaflets were sent to all households, warning the Hungarian populace of 'no-go zones' in European cities with larger proportions of migrants and national consultations were issued to citizens, in which they were asked to condemn the terrorist, monetary, and cultural threat of refugees in a lopsided public vote.

What we witness in Hungary is thus a de facto abolition of the institution of asylum, ${ }^{5}$ accompanied by serious violations of refugees' human rights in a climate of hatred that is spurred by the government itself. All in all, the desire for upholding a norm of closure in the face of a supposedly looming threat of migration is aptly described by prime minister Viktor Orbán himself: 'the question is whether we can keep ourselves out of this, whether we can preserve our culture, our Christian culture, our Hungarian culture and how we live - our way of life.... I do not want Hungary to become an immigrant country’ (Orbán 2018b).

\section{'Let others do the dirty job' or why Germany turns its eyes from human rights violations at the EU periphery}

The position of the German government on asylum appears to be rather different at first sight. In 2015, the German government decided to admit hundreds of thousands of refugees to the country, arguably ignoring the Dublin regulations requiring the first EU country into which refugees enter to process their asylum claims. This decision was accompanied by a largescale public reaction, coining the phrase of a 'welcome culture' (Willkommenskultur) in Germany and the promise that asylum claims would be processed no matter how many persons seek refuge (Funk, 2016; Hamann and Karakayali, 2016). The implied message is clear: Germany remains true to the normative principle underlying its constitutional provision on asylum, even if this requires action beyond the immediate duties laid upon them by EU law. Accordingly, the image created by politicians and reinforced in the public eye is that of a generally virtuous agent - the image of the good Samaritan who commits 'extraordinary acts of generosity' (Stern 2016: 11; Ignatieff 2017: 226) and upholds the rights of refugees no matter how many apply for asylum (see Thränhardt 2018). ${ }^{6}$

This image starkly contradicts the politics of fencing in and keeping refugees out, and we would hence expect the two to clash. In other words, we would expect resistance against the abolition of the institution of asylum and the systematic abuse of human rights at the periphery of the EU. Yet, such resistance may be searched for in vain. No actions were taken, no criticisms muttered. To the contrary, both on the EU level as well as on the level of national politics, German politicians have remained surprisingly supportive of the Hungarian government. Orbán remains a welcome guest to conservative politicians who have not only extended a welcome hand but have praised the Hungarian politics of deterrence and detainment of refugees. 
Likewise, Orbán's party, Fidesz, also remains a member of the European People's Party (EPP) in the European Parliament and, thus, a partner of other conservative parties such as the German Christian Democratic Union (CDU). Members of the German fraction of the EPP have repeatedly and openly supported Orbán's election campaigns, which were focused solely on the promise to keep the borders closed and refugees out, even at the cost of supporting a political regime that seemingly slides into autocracy (see Kelemen 2017). The German members of the EPP have reasserted their support to Fidesz as an ally on the European level (Fekete 2016). Cries for expelling the party have only materialized after the Orbán regime has attacked EPP party members publicly. Refugees and their treatment, however, have not played a role in the discourse on the Fidesz membership in the EPP. Even though the social democrats have bemoaned Orbán's policies towards refugees, they too have not taken action. The sobering fact is that Hungary's policies towards refugees play into the hands of other EU member states such as Germany. They turn their eyes away from the violation of human rights and the abolition of the institution of asylum as long as Hungary's policies keep refugees from their doorsteps. This dynamic constitutes a 'division of labor' in which Hungarian politicians such as Orbán may claim to be the sole protector of a Christian homeland, defending it from the hordes of refugees awaiting to inundate it (cf. Fekete 2016; cf. Kalmar 2018). ${ }^{7}$ Yet, it also allows for the creation of an image of core EU countries, such as Germany, as countries that do not tamper with the right to asylum - that all those who apply for asylum in Germany will receive it, so long as they qualify. The good Samaritan is nothing but an image that is painted while others keep away those asking for help. In return, the policies of sealing the external borders of the EU are supported, and the measures they entail condoned. This has been made expressively clear both in the demands of the Hungarian government for support of doing the dirty job for core EU countries, as well as in the reaction of politicians of the latter. One snippet of such expressive support reads:

And, if you permit, I would like to say one more thing about solidarity; because it does hurt us Hungarians, and we perceive it as unfair that Germany often accuses us as lacking solidarity. I just want to inform you of the fact that, in Hungary, there are 8000 armed men and women who stand and protect the border for 24 hours a day, a border through which migrants, if they succeed, come to Germany. Even if the Turkeydeal exists: If it were not for those armed Hungarians protecting the border, 4000-5000 migrants would arrive in Germany on a daily basis. We protect you. That is solidarity - I think a form of solidarity that is to be taken serious.

(Orbán 2018c) 
The protection of the external borders that Hungary guarantees is acknowledged. There is no question of that. The differences between us exist elsewhere.

(Merkel 2018, own translation)

This form of cooperation keeps refugees from entering the territory of core EU states. As such, it represents just another instrument in keeping refugees at bay. Liberal democracies, such as Germany, have long resorted to a toolbox of instruments that are designed to keep refugees from entering their territory. They have established barriers and placed hurdles in the ways of refugees attempting to enter liberal democracies. They include visa regulations requiring pre-arrival permission to enter a state's territory, which is something that refugees cannot obtain since they are only allowed to launch asylum applications on the territory of a state (Gibney 2006). They also include carrier sanctions, placing high fines on airline companies for transporting any persons without such permissions to enter a state's territory (see also Collinson 1996; Gibney 2006). Combined, they aim at reducing the range of travel options available to refugees, making seeking asylum in liberal democracies more costly and more dangerous. With regular forms of travel being ruled out, refugees turn to smugglers who charge higher prices the more hurdles there are to overcome. Supporting the establishment of barriers and condoning the policies of deterrence and detainment at the EU external borders have a similar effect. They aim at curtailing the onward movement of refugees into the direction of liberal democracies such as Germany. As such, they do not differ in principle from other forms of cooperation these same states maintain with the external neighbors of the EU. Bi- and multi-lateral agreements with states such as Libya and Turkey follow the same logic: keeping refugees from entering in exchange for material and financial support (Bialasiewicz 2012; Rygiel, Baban \& Ilcan 2016).

These measures play into what some have called the hypocrisy of asylum (see Gibney 2014). Liberal democracies, such as Germany, claim to uphold the rights of refugees. They assert that all those fleeing from war and persecution may find refuge in their countries while simultaneously placing hurdles and barriers in their way. The right to seek asylum thus remains, but it remains as a distant possibility, as an illusion of safe haven that refugees may not access. Condoning the violations of human rights and the abolition of the institution of asylum in countries such as Hungary is mere collateral damage to this end. As long as the dirty work is done at the periphery of the EU, states such as Germany turn their eyes away from such violations. After all, they may retain their image as the good Samaritan - a knight in shining armor offering to refugees the utopia of asylum. And a utopia it remains for refugees: a non-place.

\section{Conclusion}

What we are witnessing at the periphery of the EU is the systematic abolition of the institution of asylum. We are witnessing the establishment of 
border fences, detention zones for refugees, and an order inside the country that aims at concentrating unchecked power in the hands of the government in order to dominate the lives of refugees. This has led to pervasive human rights abuses of those who seek refuge from persecution and war. Yet, we are also witnessing the lack of criticism and action by states that proclaim to defend the rights of refugees. In this chapter, I have sought to answer why. I have argued that core EU states profit from the fact that countries at the EU periphery, such as Hungary, are keeping refugees at bay. I have argued that this 'division of labor' allows Hungarian politicians to reap the political fruits of demonizing refugees in claiming to be the sole protectors of a Christian European homeland from being inundated by refugees, while it simultaneously allows core EU states, such as Germany, to foster the image of states upholding the normative core underlying the right to asylum.

What does this imply? It means that we must bid farewell to a simplistic moral picture of asylum policies in contemporary Europe. The norm of closure and the entailed violations of the rights of refugees in Hungary would not be possible without other EU states standing idly by, condoning, or even supporting a halt to refugees turning up at their borders. On the other hand, it also means that the norm of a morally founded right of asylum comes at a price - a price that casts a shadow on a flawless moral self-image.

\section{Notes}

1 For an overview of the situation in Hungary during the long summer of migration, see: Migrant Solidarity Group of Hungary (2016) and Kallius, Monterescu \& Rajaram (2016), for aspects of the situation in Germany, see Herrmann in this volume and Funk (2016) for a brief overview.

2 This included a more-or-less functioning support scheme for refugees, that provided for housing money and allowances. For more on the Hungarian asylum system before 2015, see the Asylum Information Database Report (2015).

3 Cf. Szary \& Giraut (2015) and Kallius, Monterescu \& Rajaram (2016) for conceptions of mobile borders and orders that stretch beyond the demarcation lines.

4 The relevant amendment to the constitution reads: 'Any non-Hungarian citizen arriving to the territory of Hungary through a country where he or she was not exposed to persecution or a direct risk of persecution shall not be entitled to asylum' Art. XIV (4) of the Basic Law of Hungary. See also the Hungarian Helsinki Committee (2018e) for legal practice and the consequences of the legal changes.

5 This does, of course, not mean that asylum has vanished altogether and that no one receives asylum in Hungary any longer. Yet, this privilege is reserved for the friends of the government, such as the former Macedonian Prime Minister, fleeing from criminal prosecution, or to those that fit the narrative of a Hungarian nation protecting white Christian Europeans. To that end, the Hungarian government has provided asylum to fleeing Ukrainians. What this shows is not that asylum is impossible, but that the institution of asylum has vanished - that the procedurally guaranteed and fairly administered right of asylum has been abolished in Hungary. See the statement of the Hungarian Prime Minister's Office with regards to the socalled Gruevski affair (Gulyás 2018). 
6 See also an interview with Merkel in the Rheinische Post, in which she emphasizes that the right of asylum must remain unlimited (Bröcker \& Quadbeck 2015).

7 Cf. ft. 1

\section{References}

Asylum Information Database (2015). Country Report: Hungary. Available at: www. asylumineurope.org/sites/default/files/report-download/aida___hungary_thirdupdate _final_february_2015.pdf.

Asylum Information Database (2017). Country Report: Hungary. Available at: www. asylumineurope.org/sites/default/files/report-download/aida_hu_2017update.pdf.

Basic Law for the Federal Republic of Germany (1949). Germany.

Betts, A. (2015). 'The normative terrain of the global refugee regime,' Ethics $\mathcal{B}$ International Affairs 29(4), pp. 363-375.

Bialasiewicz, L. (2012). 'Off-shoring and out-sourcing the borders of Europe: Libya and EU border work in the Mediterranean,' Geopolitics, 17(4), pp. 843-866.

Binetti Armstrong, A. (2018). 'Cutes and ladders: Nonrefoulement and the Sisyphean challenge of seeking asylum in Hungary,' Columbia Human Rights Law Review 50(2), pp. 46-115.

Bröcker, M. \& Quadbeck, E. (2015). “'Grundrecht auf Asyl kennt keine Obergrenze”: Interview mit Bundeskanzlerin Angela Merkel,' Rheinische Post Online, 11 September. Available at: https://rp-online.de/politik/deutschland/angela-merkel-da s-grundrecht-auf-asyl-kennt-keine-obergrenze_aid-9533771

Collinson, S. (1996). 'Visa requirements, carrier sanctions, "safe third countries" and "readmission": The development of an asylum "buffer zone" in Europe,' Transactions of the Institute of British Geographers 21(1), pp. 76-90.

Fekete, L. (2016). 'Hungary: Power, punishment and the "Christian-national idea",' Race Eु Class, 57(4), pp. 1-15.

Funk, N. (2016). 'A spectre in Germany: Refugees, a "welcome culture" and an "integration politics",' Journal of Global Ethics 12(3), pp. 289-299.

Gibney, M. J. (2006). “'A Thousand Little Guantanamos:” Western States and Measures to Prevent the Arrival of Refugees,' in Tunstall, K. E. (ed.) Displacement, Asylum, Migration. Oxford and New York: Oxford University Press, pp. 139-169.

Gibney, M. J. (2014). 'Asylum: Principled hypocrisy,' Migration: A Compas Anthology. Oxford: COMPAS.

Gulyás, G. (2018). Statement by the Prime Minister's Office: Asylum request of Nikola Gruevski. Available at: www.kormany.hu/en/prime-minister-s-office/news/statem ent-by-the-prime-minister-s-office-asylum-request-of-nikola-gruevski

Hamann, U. \& Karakayali, S. (2016). 'Practicing Willkommenskultur: Migration and Solidarity in Germany,' Intersections 2(4), pp. 69-86.

Human Rights Watch (2016a). Hungary: Failing to Protect Vulnerable Refugees. Available at: www.hrw.org/news/2016/09/20/hungary-failing-protect-vulnerable-refugees

Human Rights Watch (2016b). Hungary: Migrants Abused at the Border. Available at: www.hrw.org/news/2016/07/13/hungary-migrants-abused-border

Hungarian Helsinki Committee (2015a). No Country for Refugees - New asylum rules deny protection to refugees and lead to unprecedented human rights violations in Hungary. Available at: www.helsinki.hu/wp-content/uploads/HHC_Hungary_Info_Note_Sep t-2015_No_country_for_refugees.pdf 


\section{F. Bender}

Hungarian Helsinki Committee (2015b). Building a Legal Fence: Changes to Hungarian asylum law jeopardise access to protection in Hungary. Available at: www. helsinki.hu/wp-content/uploads/HHC-HU-asylum-law-amendment-2015-Augustinfo-note.pdf

Hungarian Helsinki Committee (2016a). Destitute, but Waiting: Report on the Visit to the Tompa and Röszke 'Pre-Transit Zone' Area on the Hungarian-Serbian Border. Available at: www.helsinki.hu/wp-content/uploads/HHC_Röszke_Tompa_pre_transit_zone_ 22April2016.pdf

Hungarian Helsinki Committee (2016b). Hungary: Latest amendments 'legalise' extrajudicial push-back of asylum-seekers, in violation of EU and international law. Available at: www. helsinki.hu/wp-content/uploads/HHC-info-update-push-backs-5-July-2016.pdf

Hungarian Helsinki Committee (2017a). Hungary: Government's New Asylum Bill on Collective Push-backs and Automatic Detention. Available at: www.helsinki.hu/wp -content/uploads/HHC-Info-Update-New-Asylum-Bill-15.02.2017.pdf

Hungarian Helsinki Committee (2017b). Pushed Back at the Door: Denial of Access to Asylum in Eastern EU Member States. Available at: www.helsinki.hu/wp-content/up loads/pushed_back.pdf

Hungarian Helsinki Committee (2018a). Systemic Violations of Asylum-Seekers' Human Rights in Hungary. Available at: www.helsinki.hu/wp-content/uploads/OSCE-H DIM-2018-statement-Hungary-migration.pdf

Hungarian Helsinki Committee (2018b). Hungarian Government Marks World Refugee Day by Passing Law to Jail Helpers. Available at: www.helsinki.hu/wp-content/uploa ds/HUNGARIAN-GOVERNMENT-MARKS-WORL

D-REFUGEE-DAY-BY-PASSING-LAW-TO-JAIL-HELPERS-20June2018En.pdf

Hungarian Helsinki Committee (2018c). Attacking the Last Line of Defence: Judicial Independence in Hungary in Jeopardy. Available at: www.helsinki.hu/wp-content/up loads/Attacking-the-Last-Line-of-Defense-June2018.pdf

Hungarian Helsinki Committee (2018d). Hungary: Key Asylum Figures for 2017. Available at: www.helsinki.hu/wp-content/uploads/HHC-Hungary-asylum-figures-1-Janua ry-2018.pdf

Hungarian Helsinki Committee (2018e). Asylum-Seekers with Inadmissible Claims Are Denied Food in Transit Zones at Border. Available at: www.helsinki.hu/wp-content/up loads/Denial-of-food-for-inadmissible-claims-HHC-info-update-17August2018.pdf

Ignatieff, M. (2017). 'The refugee as invasive other,' Social Research: An International Quarterly 84(1), pp. 223-231.

Kallius, A., Monterescu, D., \& Rajaram, P. K. (2016). 'Immobilizing mobility: Border ethnography, illiberal democracy, and the politics of the "refugee crisis" in Hungary,' American Ethnologist 43(1), pp. 25-37.

Kalmar, I. (2018). "The battlefield is in Brussels”: Islamophobia in the Visegrád Four in its global context,' Patterns of Prejudice 52(5), pp. 1-14.

Kelemen, D. R. (2017). 'Europe's other democratic deficit: National authoritarianism in Europe's democratic union,' Government and Opposition, 52(2), pp. 1-28.

Lázár, J. (2015). Two types of border fence to be built on Serbian-Hungarian border. Available at: www.kormany.hu/en/prime-minister-s-office/news/two-types-of-border-fen ce-to-be-built-on-serbian-hungarian-border

Médecins Sans Frontieres (2017). MSF denounces the widespread violence on migrants and refugees at the Serbian/Hungarian border. Available at: www.msf.org/serbia-msf-de nounces-widespread-violence-migrants-and-refugees-serbianhungarian-border 
Merkel, A. (2015). Summer Press Conference of Angela Merkel. Available at: www.bun desregierung.de/breg-de/aktuelles/pressekonferenzen/sommerpressekonfer enz-von-bundeskanzlerin-merkel-848300

Merkel, A. (2018). Pressekonferenz von Bundeskanzlerin Merkel und dem ungarischen Ministerpräsidenten Viktor Orbán. Available at: www.bundeskanzlerin.de/bkin-de/a ktuelles/pressekonferenz-von-bundeskanzlerin-merkel-und-dem-ungarischen-minis terpraesidenten-viktor-orbán-1511460

Migrant Solidarity Group of Hungary (2016). Hungary's Long Summer of Migration. Available at: www.migszol.com/files/theme/Report/migszol_report_eng.pdf

Nagy, B. (2016). 'Hungarian Asylum Law and Policy in 2015-2016: Securitization instead of loyal cooperation,' German Law Journal 17(6), pp. 1033-1082.

Orbán, V. (2018a). 'State of the Nation' address. Budapest. Available at: www.korma ny.hu/en/the-prime-minister/the-prime-minister-s-speeches/viktor-orban-s-sta te-of-the-nation-address

Orbán, V. (2018b). Let us protect Hungary from becoming an immigrant country. Available at: www.kormany.hu/en/the-prime-minister/news/let-us-protect-hungary-from-becom ing-an-immigrant-country

Orbán, V. (2018c). Pressekonferenz von Bundeskanzlerin Merkel und dem ungarischen Ministerpräsidenten Viktor Orbán. Available at: www.bundeskanzlerin.de/bkin-de/a ktuelles/pressekonferenz-von-bundeskanzlerin-merkel-und-dem-ungarischen-minis terpraesidenten-viktor-orbán-1511460

Rygiel, K., Baban, F., \& Ilcan, S. (2016). 'The Syrian refugee crisis: The EU-Turkey “deal” and temporary protection,' Global Social Policy 16(3), pp. 315-320.

Stern, R. T. (2016). 'Responses to the "refugee crisis": What is the role of self-image among EU countries?' European Policy Analysis 10, pp. 1-16.

Szary, A.-L. A. \& Giraut, F. (2015). 'Borderities: The politics of contemporary mobile borders,' in Szary, A.-L. A. \& Giraut, F. (eds) Borderities and the Politics of Contemporary Mobile Borders. London: Palgrave Macmillan, pp. 1-19.

Thränhardt, D. (2018). 'Welcoming citizens, divided government, simplifying media: germany's refugee crisis, 2015-2017,' in Dell'Orto, G. \& Wetzstein, I. (eds) Refugee News, Refugee Politics: Journalism, Public Opinion and Policymaking in Europe. London: Routledge.

Umek, D., Minca, C. \& Šantić, D. (2019). 'The refugee camp as geopolitics: The case of Preševo (Serbia),' in Paradiso, M. (ed.) Mediterranean Mobilities: Europe's Changing Relationships. New York: Springer, pp. 37-53. 


\title{
6 Between closing borders to refugees and welcoming Ukrainian workers
}

\author{
Polish migration law at the crossroads
}

\author{
Witold Klaus
}

\section{Introduction $^{1}$}

Article 2 of the Treaty on European Union serves as a cornerstone of the values of European Union (EU) and its Member States. The Union itself is built on values that include: respect for human dignity; freedom; democracy; equality; the rule of law; and respect for human rights, including minority rights. According to the Treaty, several values are common to the society of the EU. These are: pluralism, non-discrimination, tolerance, justice, solidarity, and equality between women and men. All of these are moral principles and a beacon for each and every legislation accepted both on the EU and Member State levels. One of the important aspects of the process of Europeanization is spreading these values throughout the Member States and the neighboring countries (particularly those applying for EU membership) inter alia by including them into their legislation (Mtchedlishvili 2018).

The processes described above are rather general, and apply to a number of policies, such as foreign policy or European integration policy. But when it comes to Europeanization of migration policy that has been growing since the 1990s, another phenomenon can be observed.

[T]he Europeanization of migration policy fosters the securitization of migration it sustains a radical political strategy aimed at excluding particular categories of people by reifying them as a danger (for example, to cultural values, to the provision of social assistance, to public safety, to health etc.)

(Huysmans 2000: 771)

In the last few years however, another process has been taking place in Central-Eastern Europe that Peter Vermeersch identifies as 'the process of de-Europeanization.' Politicians who have been implementing de-Europeanization also appeal to values - values that were supposedly 'forgotten' by the EU. These politicians are trying to re-establish and defend what they call 'Christian values' (Vermeersch 2019). De-Europeanization is theoretically built on patriotism, reflecting the diverse nationalistic attitudes of its 
founding fathers in each nation. Poland serves as one example where the deEuropeanization of EU policies is occurring.

But do European migration policies reflect European values described in Art. 2 of the Treaty on European Union? In my opinion, those values are very difficult to find there. Instead, current EU migration policy puts the idea of security first and foremost as a 'super right' (or we might say as a 'super value') that justifies practically all decisions (Lemke 2014: 69-70) and brings us to the point where any other value should be subjugated to it. As a result, we are starting to face discrimination against non-EU nationals, lack of tolerance and solidarity, lack of the principle of the rule of law, etc. Thus, current EU migration policy contradicts a number of values that the EU legislation should obey. Those values are being further twisted and abused in countries where the de-Europeanization process, with its nationally-focused approach based on the exclusion of others, is taking place.

In this chapter, I deconstruct the values that Polish migration policy is built on by analyzing legal and bureaucratic activities undertaken by the Polish authorities after 2015. I present, as well, the ambiguity of this policy that vacillates between strengthening security by closing borders to refugees on the one hand, and accepting a large number of Ukrainian labor migrants on the other. I start with a short overview of the inflow of migrants and asylum seekers to Poland over the past 15 years. Then I briefly present Polish migration policy and its development after 2004 with special focus on the changes introduced after 2015, which were justified by a dramatic change of attitudes in Polish society towards refugees. Against this backdrop, I describe the most recent and very divided approach of the Polish government to asylum seekers and economic migrants, which is reflected in legal acts or proposed legislation. Drawing from these trends, I reconstruct the values that serve as the foundation for these changes.

\section{The inflow of foreigners to Poland}

Immigration has a very short history in Poland. Since the nineteenth century, Poland has mainly been a country of emigrants. For many years, the primary reasons for Poles leaving were economic and political. Following the collapse of communism in 1989, emigration remained high and increased even further after 2004 when Poland joined the EU. In 2011, the Polish Central Statistical Office estimated that over two million Poles remained outside Polish territory for a minimum of three months and 1.6 million stayed abroad for at least a year (Fihel \& Kaczmarczyk 2009; Goździak 2014; Kaczmarczyk \& Okólski 2002, 2008; Stola 1992).

For many years Poland remained a country without immigrants. In communist times, the border was practically closed and immigration scarce, with some small exceptions for students from other socialist African and Asian countries. Immigration picked up after 1990, but even then it was mainly circular and short-term by individuals undertaking irregular employment or 
involved in other forms of 'shadow economy.' The majority of immigrants to Poland were citizens of neighboring countries, primarily Ukrainians (Brunarska et al. 2016; Górny 2017; Kaczmarczyk \& Okólski 2002), people with cultural and linguistic backgrounds similar to Poles.

Between 1990 and 2012, the overall number of migrants living in Poland slowly increased, ranging between 50,000 and 150,000 . But this is not the case for Ukrainians. Before 2015, Ukrainians comprised about 30 percent of all foreigners holding residence permits, but since then their number has increased due to emigration after Russia's aggression on Ukraine in 2014. In 2018, almost two-thirds of all non-EU nationals holding temporary or permanent residence permits were Ukrainian citizens. Many more Ukrainians were working in Poland under a visa regime - with different estimates identifying as many as 1.5 million Ukrainians in Poland in 2018 (Górny et al. 2018).

Legal immigration from Ukraine was possible because of exceptionally liberal Polish labor migration legislation. A system of declarations entrusting work to foreigners has been in operation since $2007 .^{2}$ It was an easy way to obtain the necessary documents and then a visa granting legal entry and employment in Poland for six months over a 12-month period, therefore many people used this opportunity to leave Ukraine. ${ }^{3}$ Many Ukrainians had previously tried and tested the system, which made it more familiar to subsequent immigrants, and laid a ground for well-established Ukrainian social networks (Szulecka 2016b). In 2015, there was a huge increase in the number of declarations of entrusting work to a foreigner - 17 times more declarations were issued compared to the previous year, a figure which doubled again in 2016. Ukrainians constituted 98 percent of individuals who obtained the document in 2015. Ukrainians still accounted for 91.5 percent of foreigners who obtained the declarations in 2018 (Górny et al. 2018). A similar trend is also apparent if we look at work permits, although in this case the representation of Ukrainians stands at 75 percent to 85 percent in recent years, and the number of permits issued is distinctly lower.

It therefore seems that a significant group of Ukrainians used well-known channels of economic migration resulting in an unprecedented influx of Ukrainians to Poland. Despite armed conflict in Ukraine, most Ukrainians opted out of applying for international protection in Poland or any other EU country, although many Ukrainians have sought protection in Russia (Szczepanik \& Tylec, 2016).

\section{Refugees and asylum seekers in Poland}

The Polish asylum system has only been developing for fewer than thirty years, since it was only in December 1991 that Poland signed the 1951 Convention Relating to the Status of Refugees. While Poland welcomed refugees in the communist era from Greece (1948-56) and Chile (1973), the total number amounted to a mere 20,000 individuals. Since 1992, there was a consistent, albeit insignificant, inflow of asylum seekers reaching almost 


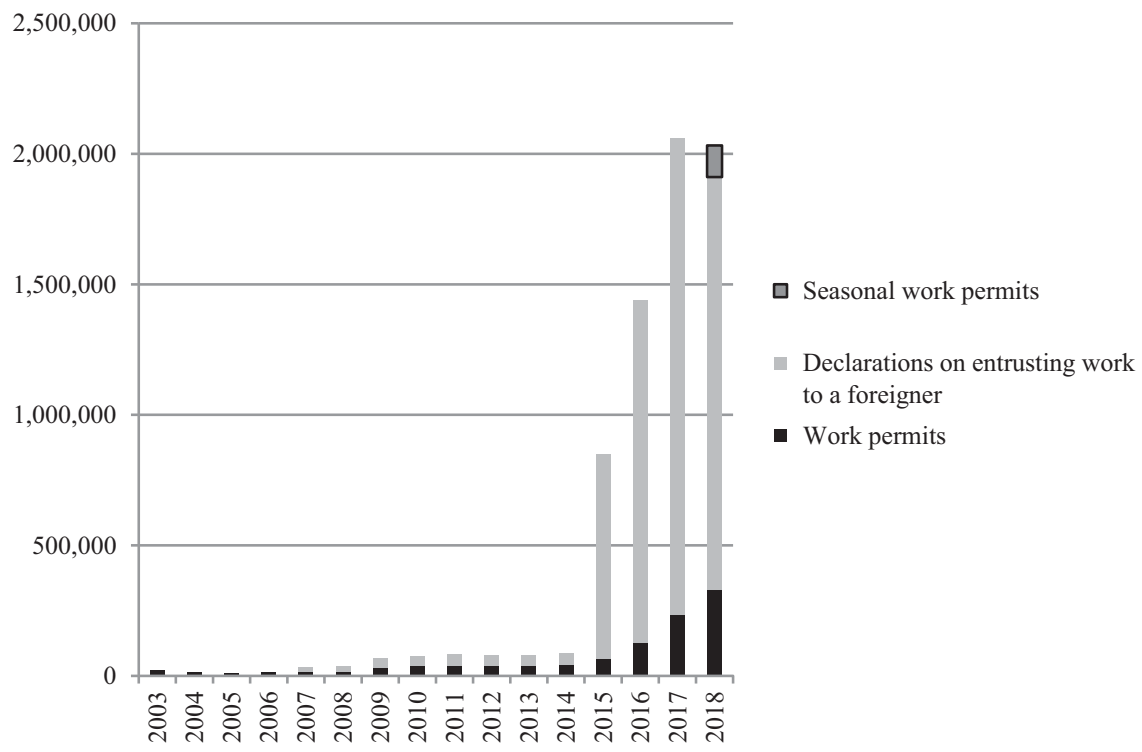

Figure 6.1 Number of work permits and declarations on entrusting work to a foreigner, issued between 2003 and $2018^{4}$

Based on: MoF 2019a; MoF 2019b

15,000 applicants in 2013. However, most of them did not stay in Poland and ended up going to other Western European countries. Few received any form of international protection. In the 1990s, only 100 individuals received protection annually, around 2,500 people annually between 2005 and 2009, and since 2010 only a few hundred people per year (see Figure 6.2). Generally speaking, the Polish asylum system is not very friendly towards asylum seekers. The chances of obtaining any form of protection are low, e.g. between 2011 and 2016 only 2 percent of applicants received refugee status, the lowest recognition rate in the entire EU. Meanwhile, refusal to be granted international protection comes with serious consequences - the foreigner must leave Poland and is often barred from entering the EU for several years.

The history of asylum in Poland can be divided into two periods. During the 1990s, individuals seeking protection came mainly from Sri Lanka, Pakistan, India, and Bosnia and Herzegovina. Since 2000, the biggest number of asylum seekers have been Russian citizens of Chechen nationality, of which over 100,000 came to Poland. Tellingly and oddly, the Polish asylum system has not registered a big number of Syrians. They began arriving in Poland after 2011 and by the end of 2018 represented only 889 individuals. However, most of the Syrians who stayed in Poland received refugee status. This cannot be said of the Chechens, for whom obtaining refugee status is nearly impossible. Instead, the Chechens might receive other forms of international protection such as subsidiary protection or humanitarian stay. 


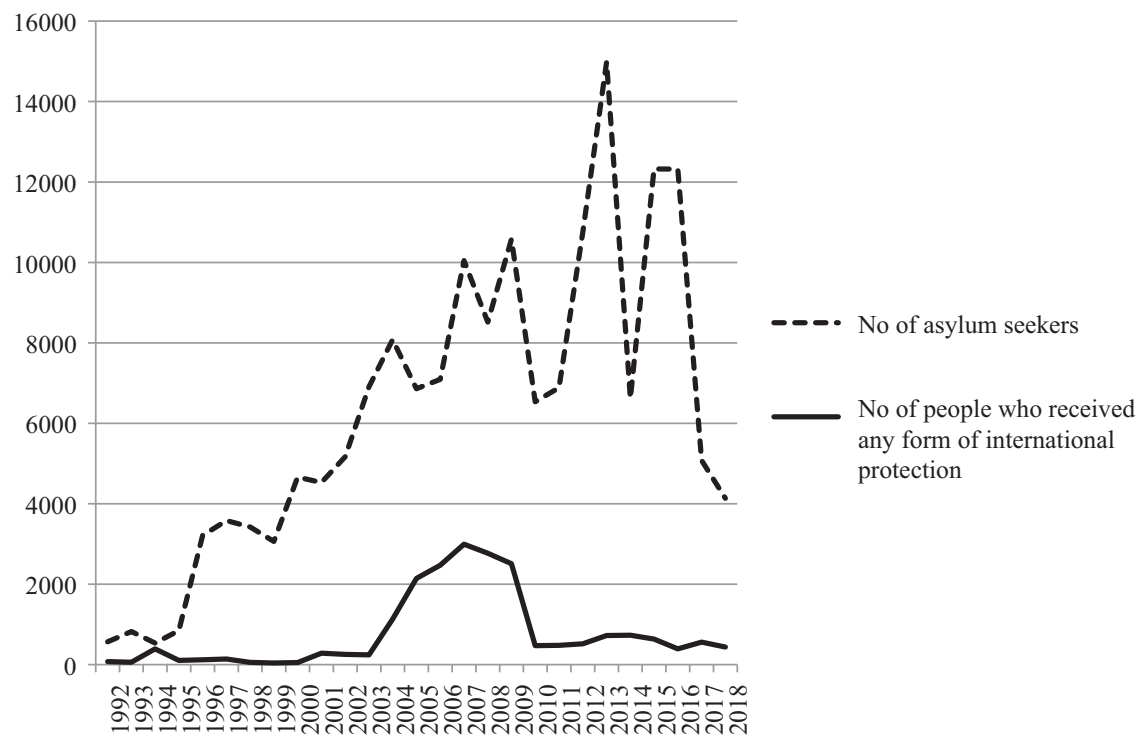

Figure 6.2 Number of foreigners, who apply for international protection and who Based on: OF 2019 were granted any form of international protection in Poland 1992-2018

In recent years, however, even these forms have been granted to Chechens exceptionally rarely. For instance, in 2018, only nine people were granted refugee status in Poland and 70 individuals obtained subsidiary protection.

Very few Ukrainians decided to apply for international protection in Poland, mostly residents of the Crimea and the Donbas region (Düvell \& Lapshyna 2015; Szczepanik \& Tylec 2016). In the five years from 2014 to 2018, Ukrainians submitted 7,066 asylum applications, with 65 percent submitted in 2014 and 2015, and less than 7 percent in 2018. Only 743 Ukrainians were granted some form of international protection, mainly subsidiary protection. The relatively low number of Ukrainian asylum seekers in Poland is a consequence of an assumption demonstrated by many EU states that Ukrainians should seek support in their home country since they are entitled to internally displaced persons' status based on the 'internal flight alternative.' Over 1.6 million Ukrainians have internally displaced persons' status, but their situation is so dire that they have no alternative but to emigrate (Krakhmalova 2018).

\section{Short overview of Polish migration policy and its history}

To enable its accession to the EU, Poland incorporated the entire body of the EU acquis common rights and obligations into its national legal order. Poland also changed its migration law based on EU regulations, which 
significantly influenced Polish legal institutions (Łodziński \& Szonert 2017). It adopted the European perspective on migration, which in the mid-1990s began to place more and more emphasis on security, curbing migration (especially the number of asylum seekers), and the protection of borders. The solutions instituted in the Polish migration law were primarily about implementing the EU regulations without regard for Polish migration reality or needs, even contradicting them at times (e.g. the obligation to introduce visas for Ukrainian nationals). These solutions were devised to address the expectations and needs of the 15 old member-states of the EU (Vermeersch 2005; Huysmans 2000).

Formal work outlining assumptions of Polish migration policy began in 2007 and ended in 2012, with the government adopting a document entitled 'Polish Migration Policy - Status Quo and Plan of Action.' The work was conducted mainly by representatives of ministries and nongovernmental organizations as well as other experts, but without the participation of politicians who, at that time, did not exhibit any interest in migration issues. The resulting policy was described as 'apolitical' (Łodziński \& Szonert 2017), meaning that Polish migration policy was developed from scratch, without a political vision, to address a low immigrant influx to Poland, and a significant acquiescence to the regulations and schemes developed on the EU level. Some of these EU schemes aided the thinking on migration in Poland (especially as regards integration of migrants), but Europeanization also came with its own baggage of negative implications resulting from perceiving migration through the issues of security and associated restrictive legislation (Pawlak 2013).

All of those processes - security-based foundation of immigration law, lack of rootedness of issues related to migration in programs of political parties, weakness of migration policy and its instruments - laid the foundations for what happened in Poland in 2015 and was an indirect consequence of the so-called refugee crisis. The consequences are indirect, since practically no refugees from the Middle East ever reached Poland, but the 'threat' of them entering the country became a key element of the parliamentary election in 2015 and was addressed by all political parties. The newly-elected government continued anti-immigration rhetoric, which had proved so successful during the campaign by bringing them victory, and initiated several changes in the law. In October 2016, the government also cancelled the 'Polish Migration Policy - Status Quo and Plan of Action' (Klaus et al. 2018: 482-7; Krzyżanowska \& Krzyżanowski 2018). A new version has never been prepared.

Jacek Skiba, Deputy Minister of Internal Affairs, responsible for migration issues in 2015, outlined the migration policy of the government in the following words: 'We are moving away from the ideological approach. In our opinion the ideological approach, based on the vision of multicultural and broad migration absorption, is flawed.' For the government 'the safety factor is extremely important, which is particularly clear in view of the recent 
terrorist attacks,' and 'the source of migration in the case of Poland should not be the Middle East area. The natural area is east of our borders' (Biuletyn Migracyjny 2016).

The change of public discourse had a dramatic impact on the public opinion towards refugees - the number of people opposing the acceptance of refugees rose from 21 percent in May 2015 to 61 percent in April 2016 (Klaus et al. 2018). The shift in public attitudes fueled the government's actions - politicians presented themselves as enforcers of the will of the people. The government's initiatives, accompanied by speeches of its representatives and their subordinated public media, played a powerful role in shaping public opinion. In the June 2017 poll, 19 percent of Poles associated the word 'refugees' with terrorists, another 14 percent linked them with 'Islamists,' and 15 percent thought it was synonymous with economic migrants. In general, half of the respondents expressed a negative attitude towards refugees, while positive sentiments were reported by only 15 percent of the polled group (Defratyka 2017). The public debate around the influx of refugees in the wake of the so-called refugee crisis contributed to a growing fear of terrorism among Poles. While in 2010 one in three polled respondents recognized the presence of a genuine terrorist threat in Poland, in 2016 this number had doubled (Feliksiak 2016).

\section{Attitudes towards refugees and asylum seekers after 2015 and its reflection in law and public policies}

After 2015, the Polish government undertook a range of legislative initiatives with the aim of portraying refugees (or, more broadly, foreigners) in a negative light - as dangerous individuals and a menace to society. One of them was the introduction of the Act of 10.06.2016 on Antiterrorist Activities. This Act authorizes law enforcement to use a wide range of powers to carry out surveillance of individuals in the territory of Poland. The new regulations define 'terrorist activities' very broadly in order to justify intervention of law enforcement, but they also fail to provide for sufficient supervision by independent courts. According to the 2015 law, all foreigners (e.g. all individuals without a Polish citizenship, including nationals of other EU Member States), are perceived as particularly suspicious. The regulations authorize almost unrestricted surveillance of this group, including phone tapping, audio and video bugging the house, and access to all forms of correspondence and data aggregated or sorted electronically by the person. A new procedure for temporary arrest was also introduced solely based on the probability that a particular person committed, attempted to commit, or prepared to commit a crime of a terrorist nature. Court proceedings can be conducted based on materials that neither the arrested individual nor their defense lawyer will have access to, rendering effective defense virtually impossible (Klaus 2017). These practices mirror those described by Andrew Cole as based on the assumption that the human rights of 'enemy aliens' 
might be sacrificed in the name of the right of citizens to security in the "war on terrorism' (Cole 2003).

A closer inspection of the 2015 Act reveals that particular powers are focused on providing protection against 'Islamic radicals.' The catalogue of terrorist events included in the version of the bill submitted to the parliament by the Polish government (Sejm ${ }^{5}$ paper no 516 of 2016) contained numerous references to Islam and its links with terrorism and extremism, including conferences and seminars organized by foreigners from so-called high-risk countries, and prison visits by imams, despite the fact that under Polish law each prisoner has the right to meet ministers of their own faith. The catalogue featured all offences committed by inhabitants of centers for asylum seekers. During parliamentary work the above list was reviewed and the current regulation ${ }^{6}$ makes no reference to religion, which had been replaced by the neutral term 'international extremism.' The catalogue of terrorist events was modified to remove the absurd examples mentioned above. However, certain groups are still seen as particularly dangerous due to their religion or ethnicity, such as when the mere presence of a foreigner is deemed as a terrorist incident simply because of the individual's ethnicity or religion. Disclosure of an offence committed by a resident of a center for asylum seekers is often treated as a potential terrorist incident.

Objections by some right-wing political parties to relocation and resettlement schemes were one of the important elements of the 2015 parliamentary election campaign. Such objections were also high on the agenda of the Law and Justice Party. They continued after the party came to power in the form of vocal protests against relocation and resettlement both in Poland and on the EU level (Wiacek 2017). At the same time, legislative action in the Polish Parliament continued to prepare for the eventuality of relocations. In the autumn of 2015, the Parliament introduced measures to raise awareness of security issues by requiring a determination by the Chief of Police, Internal Security Agency, and Border Guard whether a particular asylum seeker posed a threat to the defense and security of the state if they would have been relocated to Poland. Notwithstanding, the new government decided to further toughen the rules in 2016. The time dedicated to screening the asylum seeker requesting relocation or resettlement was extended from seven to 45 days and officials were now required to submit the security report on every foreigner. Previously, the absence of a report within the statutory period was interpreted as the absence of a threat on the part of the person. If any law enforcement agency identifies a threat, the government must refuse relocation or resettlement. Furthermore, the decision to deny relocation or resettlement is not accompanied by any justification, cannot be appealed, and is communicated to all other member states.

The government has also been working on a more general modification of the Act on Granting Protection to Foreigners since 2016. ${ }^{7}$ Every few months, a new amended version of the provisions emerges. The latest, third version of the draft was announced on February 4, 2019. The objective of 


\section{W. Klaus}

the legislation remains the same: to obstruct asylum seekers' access to international protection in Poland. The rationale for the third draft is that most of applicants are not 'genuine refugees.' In fact, the explanatory memorandum to the draft explicitly 'contains solutions to prevent the abuse of the institution of international protection by foreigners who, for reasons other than protection from persecution ... apply for said protection ... [and wish to circumvent the conditions] for crossing the external border of the European Union.' Using the 'logic' of the Polish government, special legal measures should be introduced to prevent 'abuse of refugee procedures by economic migrants.' These new mechanisms are intended not only to efficiently manage asylum processes, but also 'contribute to internal security of the state and protect the public order' (MoI 2019: 1-2).

All versions of the draft amendments provide for the introduction of accelerated border procedures with the aim of promptly handling unsubstantiated cases. Nevertheless, the list of situations allowing authorization of the border procedure is very long and covers a multitude of potential cases, including situations when the asylum seeker offers incoherent or contradictory explanations to corroborate persecution in the country of origin. It should be taken into account that the procedure of submission of an asylum application is prompt and it takes place under conditions not conducive to confidentiality, hence the potentially cryptic explanations. Other situations covered in the draft include instances when, in the opinion of a border guard, the asylum seeker poses a threat to the security of the state, or when the asylum seeker has destroyed their identification document. ${ }^{8}$ These broad formulations raise concerns that the vast majority of applicants will be fast tracked to border procedures whose primary raison d'être is speed and efficiency - the procedure should be finalized within 20 days which leaves very little time to investigate the case thoroughly. Another problem is that the procedures in the draft amendments come with considerable limitations to legal safeguards of the person and involve obligatory detention of the foreigner and their family in a detention center. What's more, an asylum seeker has no right to challenge decisions applying the border procedure to him or her. Furthermore, a negative decision denying international protection issued during the procedure is final. No administrative court proceedings can stop the expulsion of the foreigner from the territory of Poland.

In 2019, the third version of the draft also reduced the scope of protection offered to asylum seekers who have experienced any form of violence, abuse, or torture. At the moment, at least in theory, such survivors cannot be detained in a guarded center. The amendment will narrow applicability to survivors of torture and inhuman treatment, so that, for instance, women who survive abuse, including sexual abuse, will be susceptible to detention.

With plans to detain increasing numbers of asylum seekers, in November 2017, the government changed the legislation so that it now enables placing foreigners in barracks/shipping containers during their detention. Whole detention centers for foreigners may consist of containers only, behind a 
minimum three-meter fence fortified with barbed wire. The mental image is bound to conjure up a familiar and uncomfortable associations with fascist and communist camps during and after World War II.

These legal changes which have been introduced or are planned by the government reflect a radical shift in interpretation of existing asylum laws resulting in Polish borders being sealed. The number of asylum seekers that were allowed to apply for asylum dropped notably between 2017 and 2018 . This drop was not related to a change in the situation in the asylum seekers' countries of origin (primarily Chechnya), but rather was a result of marked shift in attitudes of Polish authorities towards asylum seekers and the effective closure of the Polish border to refugees. The process began in the summer of 2015 and has been gaining strength ever since. In 2018, on average, one family per day was allowed to enter Poland to apply for asylum, while the remaining people were turned away (mostly to Belarus ${ }^{9}$ ). The Polish Border Guards turn a deaf ear to requests for asylum. Desperate asylum seekers, at the moment mainly from Chechnya (in the years 2015-2016 also from Tajikistan), are relentless in their attempts to submit an application in Poland, trying several dozen times, with a record of 60 attempts. Some succeed, many don't. The whole process is humiliating and financially draining as asylum seekers need to pay for accommodation in Belarus and train tickets to Poland. Additionally, asylum seekers staying in Belarus risk being sent back to Russia by Belarusian authorities and being delivered into the hands of Chechen authorities, as they can only legally stay in Belarus for three months (Klaus 2017; Szczepanik 2018).

The situation, at odds with the Polish and international law, is the result of political decisions and a manifestation of the government's reluctance to accept refugees, Muslims in particular. And it's not a coincidence that both Chechens and Tajiks, targeted mostly by this policy, are followers of Islam. In similar fashion, the systematic refusal to grant Chechens international protection is a manifestation of the same trend. The Polish government maintains that Chechnya is a peaceful, war-free region, therefore there is no excuse for its nationals not to go back. If, however, for some unlikely reason they cannot stay in Chechnya, other regions of Russia are available. This is an example of ideological blindness that contravenes international organizations' reports on the situation in the region.

\section{Law and its responses to economic migration to Poland 2015-2018}

Despite the fact that the process of securitization of migrants was taking place, at the same time Poland has become a leader among EU countries in accepting new migrants. Over the years, employers have grown used to the presence of Ukrainians in the Polish job market. Low unemployment, which has decreased steadily since 2013 and was below 6 percent in June 2018 (GUS, 2019), along with an economic boom and significant emigration of Poles to other EU states has resulted in shortages in the labor market. 
Recruitment of Poles was often impossible due to lack of interest in the advertised low-skilled vacancies and the gap has been filled by labor migrants, predominantly Ukrainians (Wysieńska-Di Carlo \& Klaus 2018). Employers realize that they simply cannot manage without foreigners, but at the same time their attitudes towards migrants are not very open. In their eyes, Ukrainians are nothing more than cheap labor addressing pressing temporary shortages who will miraculously disappear when the demand expires. Moreover, business owners seem to assume that the workforce supply will continue as long as there is demand, but there is little evidence of any long-term expectation of migration. When employers think of foreigners, they mean Ukrainians, and they are rather reluctant to hire people of other ethnicities (Kubiciel-Lodzińska \& Maj 2017; Wysieńska-Di Carlo \& Klaus 2018).

Since 2015, there has hardly been a united governmental front as far as economic migration is concerned. In terms of legislation, there has been friction and differences of opinion between the Ministry for Internal Affairs and ministries responsible for economy and the labor market. Representatives of the Ministry of Interior advocated restrictions for economic migrants by tightening the legalization of their stay and work procedures. At the same time authorities responsible for economic growth favored a more relaxed approach, promoting the interests of Polish economy, and easing pressure from business owners (Gońda \& Klaus 2018).

The bone of contention was the approach to declarations on entrusting work to foreigners. The regulation had long been criticized as leaving room for abuse - it allowed big groups of foreigners (as discussed above) to arrive legally, but left the authorities with little control over the process, neither did they sufficiently safeguard migrants arriving to work. As a consequence, the regulations enabled people to arrive legally, but a lot of them took up illegal forms of employment ${ }^{10}$ (Szulecka 2016a). It allowed employers to reduce labor costs (by not paying taxes and social security contributions, disregarding health and safety measures, etc.), but the flip side was that it often led to cases of abuse of Ukrainian workers by Polish employers (Keryk 2018).

Preparation to change the regulation with regard to declarations began in connection with Poland having to implement Directive 2014/36/EU on the conditions of entry and stay of third-country nationals for the purpose of employment as seasonal workers (which partially overlapped with declarations' system). As a result, the legislation concerning declarations was slightly modified in 2018 by granting more control over the process to various public services. Moreover, there was some consideration over how to incorporate the new seasonal work permits into the system existing in Poland. The ministry of internal affairs insisted they be controlled by the government, which would render the legislation practically defunct making it too bureaucratic and difficult to manage. Eventually, the permits are issued by local authorities, which are also responsible for registering declarations in 
the central electronic system. The procedure itself is not overly complicated and it resembles declarations. In fact, both institutions complement each other - any work deemed seasonal requires seasonal work permits, while the remaining ones are based on declarations of entrusting work to a foreigner. In addition, as a result of pressure exerted by employers and their organizations, many Polish regions did away with labor market tests for certain occupations in the process of issuing work permits. The role of the test was to verify whether the vacancy might be filled by a Pole. Since the shortage of candidates in some low-skilled jobs has been very acute, the test is disregarded in construction, for truck drivers, domestic workers, and kitchen workers. Owing to this change, employing a foreigner became a less timeconsuming affair (Wysieńska-Di Carlo \& Klaus 2018).

The ministries of economy and labor engaged in further planning of how to facilitate foreigners' access to the labor market in Poland. In the summer of 2018, they put forward a draft labor market bill which would extend the working period from six to 12 months based on declarations on entrusting work to a foreigner. In the process of social consultation, employers' organizations and NGOs jointly demanded further and more progressive changes provide more flexibility in employing migrants (SIP 2018). However, work on the bill was suspended by the government without any notice or explanation, and the document itself vanished from the governmental website. It shows ambiguity within the Polish government when it comes to migration law and, more general, migration policy.

\section{Values and Polish migration policy after 2015}

Legal provisions should reflect values of the society, so it is worth taking a look at attitudes of Polish society towards migrants. Data from the European Social Survey ${ }^{11}$ shows that while Poles do not perceive migrants as a serious threat, but they also don't like them and don't want them on Polish soil (Wysieńska-Di Carlo 2018b). The high level of antipathy towards foreigners is a result of xenophobic sentiments, particularly towards Muslims, Roma or Jews, instead of general anti-immigrant attitudes (Wysieńska-Di Carlo 2018a). Catholicism has a lot to answer for in this state of affairs - it plays an important role in establishing Polish identity and is instrumental in reinforcing the concept of Poland as a 'bulwark of Christendom.' Thus, there is a strong link between the dislike of foreigners and islamophobia, as well as a conflation of refugees with Islamic terrorists (Goździak \& Márton 2018). Still, Polish xenophobia is hardly a new phenomenon. It's long been a fixture in the Polish cultural landscape, temporarily obscured from sight by the more recent need to be perceived as part of the European community (Vermeersch 2019).

Despite the fact that opinion polls show Poles accepting of foreigners, as long as they are ethnically similar (Wysieńska-Di Carlo 2018a), it would be disingenuous to claim that Ukrainians are made to feel overly welcome by 
Polish society - only one in four Poles admits to liking Ukrainians. Indeed, in the last two years Poles have become more insular and their friendliness towards people from all nations has waned, particularly for individuals from Asian, Arab, and Roma ethic groups (Omyła-Rudzka 2018).

Xenophobia, which we could call an 'anti-value,' has been very present in Polish migration policy since the end of 2015. It laid a good foundation for number of legislative initiatives, bureaucratic attitudes, or lack of changes that I described above. It is easy to see from the $s$ and arguments of the Polish government that the paramount value that guided authorities to introduce various initiatives has been based on fear and security derived from xenophobia. Ensuring security requires the identification of the enemy that commands fear. Currently, refugees - dehumanized, depicted as terrorists, and posing an ultimate threat on the physical and cultural level - constitute that enemy. Once the 'good enemy,' as Jock Young put it, is defined, and the danger made real, we have the right and obligation to resort to any measure to defend ourselves (Young 2007: 35f). Society presents government with a carte blanche to act on its behalf, and security becomes a new super value overriding others, including human dignity, freedom, equality, the rule of law, and respect for human rights.

Peter Vermeersch observes that EU values also include reconciliation and common prosperity. Recently, EU values have been perhaps upstaged by petty national claims borne out of historical insecurities and the childish blame game of who is innocent and who is guilty. The trend is notably visible in the countries of Central and Eastern Europe, including Poland, where a new value of victimhood has been born. Victimhood nationalism feeds off moral superiority, hurt, and a sense of threat from the enemy outside. Victimhood nationalism is based on the assumption that although we are now plenty, we used to be the oppressed minority whose rights were violated. If we fail to act, history might repeat itself.

In the Polish case, contemporary victimhood politics includes such topics as the potential victimisation of Poles through ethnic heterogeneity and multiculturalism; the threat posed by Marxist multiculturalism and the EU for Catholic and Polish speaking identity, and the potential loss of sovereignty.

(Vermeersch 2019: 120)

Thus, acting on behalf of society to protect it becomes a moral obligation. The external enemy is forever shapeshifting, assuming the form of the EU, whose values the Polish government rejects, or various minorities like refugees and migrants. Confronted with such threats, the Polish government is obliged to defend the Polish nation from enemies - even though they are imagined and falsely created than real. Indubitably, this is exactly how the Law and Justice government understands its mission. 
In a number of situations, the Polish government has acted in line with European migration legislation. However, these similarities do not mean that Polish values are in line with European values. One could assume that European law mirrors European values, but when it comes to migration law it seems that this is not the case. Stripping asylum seekers of basic rights like fair trial and personal freedom, closing borders in refugees' faces, letting people drown in the sea and punishing civil society activists for rescuing them, sending refugees back to other countries where they are not safe - all of these behaviors are allowed by the EU legislation. They are far away from any values that should be common to all Europeans.

\section{Notes}

1 Research presented in this article is part of the project 'Ensuring the safety and public order as a justification of criminalization of migration' financed by the National Science Center, Poland under the grant number 2017/25/B/HS5/02961.

2 While the work permit system in Poland is very similar to the most of systems operating in other EU countries, Polish specificity is an invention of a parallel and simplified system called 'a system of declarations of entrusting work to a foreigner.' It allows employers to register a foreign employer in a very fast and easy procedure, without many formalities, and free of charge (since the beginning of 2018 a symbolic fare have been introduced). The system was primarily invented for seasonal workers, but after a few months it was broaden and started to cover all forms of labor. Planned as an exception and supplement to the main system of work permits, the system of declarations of entrusting work to a foreigner has become a leading procedure for employment of foreigners in Poland (see: Szulecka 2016b).

3 Apart from Ukrainians, the scheme is also available to Armenians, Belarusians, Russians, Georgians, and Moldovans.

4 The data shows the number of documents issued, rather than the number of people. It is especially important in the context of declarations entrusting work to a foreigner, since a number of declarations can be issued for one person. Also, not every person who obtained the declaration arrived in Poland. It is estimated that around 60 to 65 percent of the total number of declarations issues translates into the number of individuals who came to Poland and work there (Górny et al. 2018).

5 Sejm is the name of the lower chamber of the Polish parliament.

6 Decree of the Minister of Interior and Administration on the catalogue of terrorist events.

7 The subsequent stages of the work are documented at https://legislacja.rcl.gov. $\mathrm{pl} /$ projekt $/ 12294700 / \mathrm{katalog} / 12410554$.

8 Unfortunately, the measures are generally in line with the provisions of Directive 2013/32/EU on common procedures for granting and withdrawing international protection (recast).

9 Over 90 percent of asylum applications have been in fact submitted over the years in one and the same Border Guard facility - at the train border crossing between Poland and Belarus, in the small town of Terespol.

10 There is wide social acceptance for unregulated work both in Poland and in Ukraine.

11 More information about this research could be found here: www.europeansocia lsurvey.org/ 


\section{References}

Biuletyn Migracyjny (2016). "Pragmatycznie, a nie ideologicznie” - o polityce migracyjnej Polski Jakub Skiba, Sekretarz Stanu w MSWiA, w rozmowie z Renatą Stefańską i Moniką Szulecką,' Biuletyn Migracyjny 55, pp. 2-4.

Brunarska, Z., Kindler, M., Szulecka, M., \& Toruńczyk-Ruiz, S. (2016). 'Ukrainian Migration to Poland: A “Local” Mobility?' in Fedyuk, O. \& Kindler, M. (eds), Ukrainian Migration to the European Union. Lessons from Migration Studies. Cham: Springer, pp. 115-132.

Cole, D. (2003). Enemy Aliens: Double Standards and Constitutional Freedoms in the War on Terrorism. New York: The New Press.

Defratyka, A. (2017). 19\% Polaków kojarzy słowo „uchodźcy’ z terrorystami (sondaż). Available at: http://ciekaweliczby.p1/19-polakow-kojarzy-slowo-uchodzcy-z-terror ystamiakow-kojarzy-slowo-uchodzcy-z-terrorystami/

Düvell, F. \& Lapshyna, I. (2015). 'The EuroMaidan protests, corruption, and war in Ukraine: Migration trends and ambitions,' Migration Information Source, Online Journal of the Migration Policy Institute. Available at: www.migrationpolicy.org/article/ euromaidan-protests-corruption-and-war-ukraine-migration-trends-and-ambitions

Feliksiak, M. (2016). Zagrożenie terroryzmem. Komunikat z badan 127. Centrum Badania Opinii Społecznej. Available at: www.cbos.pl/SPISKOM.POL/2016/K_127_16.PDF

Fihel, A. \& Kaczmarczyk, P. (2009). 'Migration: A threat or a chance? Recent migration of Poles and its impact on the Polish labour market,' in Burrell, K. (ed.) Polish Migration to the UKin the 'New' European Union After 2004. Farnham and Burlington: Ashgate, pp. 23-48.

Gońda, M. \& Klaus, W. (2018). 'Czynniki kształtujące polskie polityki imigracyjną i integracyjną w opinii badaczy i praktyków,' Polityka Społeczna 45(11/12), pp. 16-23.

Górny, A. (2017). 'All circular but different: Variation in patterns of Ukraine-toPoland migration,' Population, Space and Place 23(8). Available at: https://doi.org/ $10.1002 /$ psp. 2074

Górny, A. et al. (2018). Imigranci w Polsce w kontekśsie uproszczonej procedury zatrudniania cudzoziemców. Warszawa: Ośrodek Badań nad Migracjami UW. Available at: www.migracje.uw.edu.pl/wp-content/uploads/2016/11/raport-power.pdf

Goździak, E. M. (2014). 'Polish migration after the fall of the Iron Curtain,' International Migration 52(1), pp. 1-3.

Goździak, E. M. \& Márton, P. (2018). 'Where the wild things are: Fear of Islam and the anti-refugee rhetoric in Hungary and in Poland,' Central and Eastern European Migration Review 7(2), pp. 125-151.

GUS (2019). Unemployment Rate 1990-2018. Warszawa: Central Statistical Office. Available at: https://stat.gov.pl/en/topics/labour-market/registered-unemployment/ unemployment-rate-1990-2018,3,1.html

Huysmans, J. (2000). 'The European Union securitization of migration,' Journal of Common Market Studies 38(5), pp. 751-777.

Kaczmarczyk, P., \& Okólski, M. (2002). 'From Net Emigration to Net Immigration Socio-economic Aspects of International Population Movements in Poland,' in Rotte, R. \& Stein, P. (eds) Migration Policy and the Economy: International Experiences. Munich: Hanns-Seidel-Stiftung, Academy for Politics and Current Affairs, pp. 319-348.

Kaczmarczyk, P., \& Okólski, M. (2008). 'Demographic and labour-market impacts of migration on Poland,' Oxford Review of Economic Policy 24(3), pp. 599-624. 
Keryk, M. (2018). Working in Poland: Violations of the Labour Rights of Ukrainian Migrants in the Construction and Services Sectors. Warszawa: Fundation "Our Choice". Available at: http://pl.naszwybir.pl/wp-content/uploads/sites/2/2018/03/raport-online-en.pdf

Klaus, W. (2017). 'Closing gates to refugees: The causes and effects of the 2015 "Migration Crisis" on border management in Hungary and Poland,' Yearbook of the Institute of East-Central Europe 15(3), pp. 11-34.

Klaus, W., Lévay, M., Rzeplińska, I. \& Scheinost, M. (2018). 'Refugees and asylum seekers in Central-European Countries - reality, politics and the creation of fear in societies,' in Kury, H. \& Redo, S. (eds) Refugees and Migrants in Law and Policy Challenges and Opportunities for Global Civic Education. Cham: Springer, pp. 457-494.

Krakhmalova, K. (2018). 'Internally displaced persons in pursuit for access to justice: Ukraine,' International Migration. Available at: https://doi.org/10.1111/imig.12500

Krzyżanowska, N. \& Krzyżanowski, M. (2018). "Crisis” and migration in Poland: Discursive shifts, anti-pluralism and the politicisation of exclusion,' Sociology 52(3), pp. 612-618.

Kubiciel-Lodzińska, S. \& Maj, J. (2017). 'The tendency of entrepreneurs to employ foreigners: Labour immigrants in the opinion of employers,' Central and Eastern European Migration Review, 6(2), pp. 176-191.

Lemke, T. (2014). 'The risks of security: Liberalism, biopolitics, and fear,' in Lemm, V. \& Vatter, M. (eds) The Government of Life: Foucault, Biopolitics, and Neoliberalism. New York: Fordham University Press, pp. 59-74.

Łodziński, S. \& Szonert, M. (2017). “Niepolityczna polityka”? Kształtowanie się polityki migracyjnej w Polsce w latach 1989-2016,' Studia Migracyjne - Przeglad Polonijny, 2(164), pp. 39-66.

MoF (2019a). Foreigners Working in Poland 2008-2018. Statistical Data by the Ministry of Family, Labor and Social Policy. Available at: https://archiwum.mpips.gov.pl/ana lizy-i-raporty/cudzoziemcy-pracujacy-w-polsce-statystyki/

MoF (2019b). Seasonal Work Permits 2018. Statistical Data by the Ministry of Family, Labor and Social Policy. Available at: http://psz.praca.gov.pl/web/urzad-pracy/ -/8180228-zezwolenia-na-prace-sezonowa-cudzoziemca

MoI (2019). Uzasadnienie do projektu ustawy o zmianie ustawy o udzielaniu cudzoziemcom ochrony na terytorium Rzeczypospolitej Polskiej oraz niektórych innych ustaw. 6 May. Available at: https://legislacja.rcl.gov.pl/docs//2/12294700/12410552/12410553/dokum ent379937.docx

Mtchedlishvili, D. (2018). 'Theorising Europeanisation in European literature: Conceptualisation and operationalisation,' Australian and New Zealand Journal of European Studies 10(1), pp. 79-91.

OF (2019). Statistical Data on Proceedings Regarding Foreigners in Poland 1998-2018 by the Office for Foreigners. Available at: https://udsc.gov.pl/statystyki/raporty-okre sowe/zestawienia-roczne/

Omyła-Rudzka, M. (2018). Stosunek do innych narodów. Komunikat z badan 37. Warszawa: Centrum Badania Opinii Społecznej. Available at: www.cbos.pl/SPISKOM. POL/2018/K_037_18.PDF

Pawlak, M. (2013). 'Imitacja w tworzeniu polskiej polityki integracji cudzoziemców,' Studia Migracyjne - Przeglad Polonijny 39(3), pp. 97-122.

SIP (2018). Remarks of Employers' Organizations and NGOs to the Project of the Act on Labor Market of 2018 Regarding Employment of Foreigners in Poland. Available at: https://interwencjaprawna.pl/wp-content/uploads/2018/08/pismo-do-m inisterstwa.pdf 
Stola, D. (1992). 'Forced migrations in Central European history,' The International Migration Review 26(2), pp. 324-341.

Szczepanik, M. (2018). 'Border politics and practices of resistance on the eastern side of "Fortress Europe": The case of Chechen asylum seekers at the BelarusianPolish border,' Central and Eastern European Migration Review 7(2), pp. 69-89.

Szczepanik, M., \& Tylec, E. (2016). 'Ukrainian asylum seekers and a Polish immigration paradox,' Forced Migration Review 51, pp. 71-73.

Szulecka, M. (2016a). 'Paradoxes of formal social control. Criminological aspects of foreigners' access to the polish territory and the labour market,' Biuletyn Polskiego Towarzystwa Kryminologicznego 23, pp. 79-95.

Szulecka, M. (2016b). 'Regulating movement of the very mobile: Selected legal and policy aspects of Ukrainian migration to EU countries,' in Fedyuk, O. \& Kindler, M. (eds) Ukrainian Migration to the European Union. Lessons from Migration Studies. Cham: Springer, pp. 51-72.

Vermeersch, P. (2005). 'EU enlargement and immigration policy in Poland and Slovakia,' Communist and Post-Communist Studies 38, pp. 71-88.

Vermeersch, P. (2019). 'Victimhood as victory: The role of memory politics in the process of de-Europeanisation in East-Central Europe,' Global Discourse: An Interdisciplinary Journal of Current Affairs 9(1), pp. 113-130.

Wiącek, E. (2017). 'Poland's refugee policy and polish society between values of survival and self-expression,' Relacje Międzykulturowe - Intercultural Relations 2. Available at: www.ism.uj.edu.pl/wp-content/uploads/2017/11/IR-Cultures-Values-Identities-2017-nr. 2.pdf\#page $=166$

Wysieńska-Di Carlo, K. (2018a). 'Niechęć wobec migrantów: rasizm i ksenofobia w Polsce na tle europejskim,' in Sztabiński, P. B. \& Sztabiński, F. (eds) PolskaEuropa. Wyniki Europejskiego Sondażu Społecznego 2002-2016/17. Warszawa: Wydawnictwo IFiS PAN, pp. 25-34.

Wysieńska-Di Carlo, K. (2018b). 'Zmiany w opiniach wobec imigracji w Polsce na tle europejskim,' in Sztabiński, P. B. \& Sztabiński, F. (eds) Polska-Europa. Wyniki Europejskiego Sondażu Społecznego 2002-2016/17. Warszawa: Wydawnictwo IFiS PAN, pp. 10-24.

Wysieńska-Di Carlo, K. \& Klaus, W. (2018). Pracodawcy i pracodawczynie a zatrudnianie cudzoziemców i cudzoziemek. Warszawa: Stowarzyszenie Interwencji Prawnej. Available at: https://interwencjaprawna.pl/dla-pracodawcow/files/SIP_RAPORT_ FULL_ONLINE_pdf

Young, J. (2007). The Vertigo of Late Modernity. Los Angeles and London: SAGE Publications. 


\title{
7 Debating deportation detention in Germany
}

\author{
The many faces of the rule of law
}

Johanna Caroline Günther

\section{Introduction}

Deportation detention ${ }^{1}$ and deportation detention facilities are controversial, yet seldom surfacing topics in German public debate; similarly, research on the politics and policies of deportation detention in Germany is scarce. Deportation detention is an instrument aimed at ensuring the seamless deportation of a person who despite being obliged to leave for their country of origin, a safe third country, or another member state of the European Union, has refused to do so voluntarily (Keßler 2019).

Through an analysis of the portrait of deportation detention as painted by German news media, I map out the values and actors within the debates about, and approaches to, deportation detention in Germany. By studying the contestation of deportation detention, I investigate the value practices and value agents that shape German asylum policy. In this chapter, I set out to answer the following questions: do descriptions of the context in which deportation detention is implemented differ, depending on different groups of actors? Are the values these actors refer to when talking about deportation detention similar or different? Finally, do they understand the same thing when talking about specific values?

Finding answers to these questions not only helps bring to light the influential stakeholders within the debates on and implementation of deportation detention; it also speaks to the larger dynamics regarding the evolution of asylum policy in Germany. Lastly, capturing the values surfacing in this context is essential to understanding the underlying drivers of policy decisions, as well as shifting public perceptions.

I define values, in line with Rokeach's conception, as abstract ideals, positive or negative, which are representative of a person's beliefs about adequate modes, means, and ends of action: 'In brief, then, values may be thought of as global beliefs about desirable end-states underlying attitudinal and behavioral processes' (Rokeach 1979: 72). I conceive of value agents as individuals or collectives, such as non-governmental organizations or governmental institutions, who promote a specific set of values through their statements, actions and proliferated practices. 


\section{2}

J. C. Günther

Not only is the debate on the purpose and practices of deportation detention in Germany representative of partisan political conflicts. It is also closely linked to a value-based divide within Germany society: on one side, individuals and organizations advocating an open, rights-centered approach to migration, on the other actors and groups invoking sentiments of xenophobia and nationalism. Both camps, however, refer to highly value-driven concepts like the rule of law as well as a sense of justice when arguing their positions. This chapter marks an attempt to further split open these arguments and analyze the underlying values.

In Germany, the latest development in a long chain of events in the context of deportation detention is the so-called Geordnete-RückkehrGesetz (Orderly Return Law). It was introduced by the Ministry of the Interior and passed by the German Bundestag in June 2019. The law aims at improving enforcement of deportations of rejected asylum-seekers (Geordnete-Rückkehr-Gesetz 2019). In addition to expanding the instrument of deportation detention the law requires asylum-seekers to remain in first-reception facilities for up to 18 months. The law also stipulates a temporary suspension of the separation of deportation detention and penal detention facilities in order to counter the lack of detention places in deportation detention facilities - 500 places in penal facilities are to be reassigned to deportation detention. The law follows the rationale of the coalition agreement that the German Federal Government concluded in March 2018. The coalition agreement announced that the government was going to facilitate and expand detention for migrants pending expulsion: 'We are going to enhance the practicability of deportation detention and deportation custody; we are going to reduce and clarify the requirements. The goal is to significantly increase the quota of return and deportation measures' (CDU, CSU \& SPD 2018: 107).

Several similarly striking events had preceded this legislation. In September 2016, German Chancellor Angela Merkel was cited in the German media calling for 'deportation, deportation and again, deportation' (Pany 2016) in a non-public meeting of the parliamentary group. This statement marked a rapid departure from the welcoming slogan of summer 2015: 'We can do this.' According to various media outlets, Merkel reinforced her changed narrative during Germany Day (Deutschland Tag) of the Young Union, the joined youth organization of the two conservative German political parties, CDU and CSU, in October 2016 when she said: 'we need a national effort for strict deportation' (Unknown 2016). In July 2017, the German Bundestag passed the first law on 'improved enforcement of the obligation to leave the country' (Gesetz zur besseren Durchsetzung der Ausreisepflicht 2017) amending the provisions on deportation detention set by $\S 62$ of the Residence Act (Aufenthaltsgesetz 2017). In July 2018, the Federal Ministry of the Interior published its much-anticipated 'Migration Masterplan' (Masterplan Migration). Paragraph 59 stresses the importance of deportation detention in order to prevent migrants from 
absconding, and to increase (forced) returns. It specifies that the federal states are to create more places in deportation detention facilities and that further options for the federal government to build its own facilities are to be evaluated (Federal Ministry of the Interior 2018).

Following these political and legislative developments, in the past three years, the German federal states (Länder) have taken steps to expand existing detention facilities, establish a new form of centralized 'reception, decision and return centers' (AnkER Zentren) where asylum-seekers are to remain until the decision is final regarding whether they can stay or must return to their countries of origin or to a safe transit country. According to unofficial statistics, 676 places in deportation detention facilities are currently available. An additional four facilities offering 440 more places are being established. Moreover, 160 more places are to be created within the already existing facilities (Keßler 2019).

Meanwhile, civil society organizations are implementing a campaign against deportation detention: 100 years of deportation detention. 100 years of innocent prisoners (100 Jahre Abschiebehaft. 100 Jahre unschuldig in Haft). The campaign is civil society's most coordinated effort yet to organize at the federal level and harmonize protests, public talks, and events promoting the abolishment of deportation detention (Gockel 2019).

The subsequent sections address selected findings from the analysis of media articles and interviews that help understand which issues, values and actors emerge within the context of deportation detention in Germany. A section on the impact of the European context as addressed in the media articles and highlighted in the interviews concludes the analysis. The discussion of selected topics from the articles and interviews is crucial to understanding the surfacing values within a larger context of shifting public debate, a polarizing political landscape and a diversifying set of influential stakeholders.

\section{Analyzing references to deportation detention - some methodological considerations}

The findings presented in this chapter are based on a qualitative content analysis of German news articles from three media outlets and a randomly selected sample of articles by different news outlets, all of which were published in the period from January 1 to December 10, 2018. This time frame was chosen to ensure that the implications of the key policy shifts outlined above were accounted for, the new government coalition had consolidated its policy priorities and had started executing them, and the revisionary efforts at European level concerning the Common European Asylum System (CEAS) could be integrated. In addition to the analysis of news articles, I conducted interviews with lawyers and representatives of civil society organizations, all of whom promote the rights of deportation detainees. 
Pursuing a predominantly qualitative approach to content analysis (Schreier 2013) - coupled with elements of quantitative media content analysis (Neuendorf 2017) - I identified three relevant media outlets representing a broad spectrum of political positions and audiences: Süddeutsche Zeitung, Spiegel Online, and BILD. The selection of these three media outlets was based on considerations such as political tenor, reach, and coverage. All three media outlets report on local incidents as well as nation-wide news. While Süddeutsche Zeitung and Spiegel Online belong to the left-wing, social-democratic camp of news media, BILD represents a more conservative agenda. To account for other outlets and political leanings, I conducted an online news search for the terms 'Abschiebehaft' and 'Abschiebungshaft' (both: deportation detention) for the same period of time and added the resulting articles to the analysis. ${ }^{2}$ The interviews with representatives of civil society organizations were then used as additional sources of information and to expand on the opinions offered in the media articles.

The quantitative nature of media analysis, as for instance promoted by Neuendorf (2017), allowed me to integrate observations on more structural features such as the thematic category a given article was tagged with, whether the article was written by a journalist from the selected outlet or a news agency, or the frequency of references to certain values: 'Content analysis may be briefly defined as the systematic, objective, quantitative analysis of message characteristics' (Neuendorf 2002: 1). Qualitative content analysis on the other hand comes in as a bridging tool linking the rigorous categorybased approach of quantitative content analysis with interpretative procedures uncovering contextual meaning. Due to their significant difference in levels of objectivity, both methods do not seem reconcilable at first glance. Yet, they inform each other when applied systematically and in separate, consecutive steps.

\section{The 'local hook': deportation detention as a local phenomenon in news articles}

A total of 139 articles - divided into four groups - constituted the body of analysis: Süddeutsche Zeitung contributed 46 articles. Spiegel Online provided 17 articles. BILD published 24 articles within the analyzed period. The additional sample, which encompassed a ratio of approximately two thirds conservative or populist and one third left-liberal to socialist media outlets accounted for 52 articles. For all three selected media outlets a peak of articles addressing deportation detention can be observed in May, with a total of 27 articles featuring the topic 'deportation detention' either as a main or as a side topic. In June and July, 17 and 18 articles, respectively, were published by the selected media outlets, making these three months the period with the densest coverage of deportation detention. Two key events can be held responsible for this observation: the election campaigns in Bavaria which featured asylum and deportation among the central topics, and a 
violent incident at a migrant reception center in Ellwangen, Baden-Wurttemberg, which occurred during a deportation attempt. In February 2018, issues related to deportation detention received the least attention with only five articles published.

When analyzing the tags the editors chose for the individual articles, the picture is very diverse: assigned tags vary from 'Legislative proposals,' 'Bavaria's prime minister,' and 'Rule of law' via 'Islamist.' 'Reception facility for asylum-seekers,' 'Protests in Ellwangen' and 'Germany's biggest deportation detention facility' to 'Government statement,' 'Deportation debate' and 'Munich airport.' ${ }^{3}$ It is however striking that all outlets report on issues related to deportation detention predominantly from a local angle, using city names as tags rather than thematic categories like 'Deportations' or 'Asylumseekers.' In total, 36 articles are tagged with a city name. Spiegel Online deviates from this pattern and more frequently assigns thematic categories instead of geographical ones. In terms of thematic categories, 'Politics' (27) and 'Regional' (36) are the ones assigned most often.

\section{The politicization of deportation detention - a representation of partisan political struggles}

The entirety of articles produced 24 topics shaping the context of debates on deportation detention. References to legislation and legal procedures regarding deportation detention were the most frequently occurring theme in the media sample (173). Then followed mentions of policies related to deportation detention and political conflicts regarding the set-up, requirements, and desirability of deportation detention as a tool to enforce returns (116). The third theme emerging from the articles was background information, for instance listing the nationalities of detained migrants, the number of detention places, or the historical development of deportation detention in Germany (113). In a nutshell, most articles focused on, or at least mentioned, either legislative changes or concrete legislative proceedings, policy proposals or political controversies surrounding policies, and information on deportations, deportation detention and detention facilities in a more abstract fashion.

It should be noted that even where media reported on specific cases or incidents involving a detained migrant, there were almost no mentions of the migrants' or detainees' perspectives. Only one article explicitly reported migrants' views on an incident that had led to the transfer of three persons into deportation detention. Another report portrayed the stories of deportation detainees in the detention facility in Büren as told by the concerned individuals. The lack of perspectives of migrants and detainees was corroborated by interviewees who clarified that the limited access for non-governmental organizations, media and legal aid practitioners combined with the fact that 'detainees don't have a lobby' and deportation detention facilities were 'operated like black boxes' resulted in the negligence 
of detainees' voices. Instead, individual cases of detainees were overwhelmingly addressed in the context of either newly emerging legislation and legal steps which must be complied with when detaining a migrant (34), or in relation to acts of violence and crime committed by detainees or guards (33). The third topic arising in regard to individual cases of detainees relates to the latter category: the articles focusing on specific cases or incidents also referred to individuals posing a threat to public security (18). Hence, they reiterated the perception that deportation detention provided an essential tool to combat serious crimes. On one hand, these observations could hint towards the limitations of the media's interest in the processes and events occurring inside deportation detention facilities. On the other, limited coverage of incidents inside detention facilities as well as detainees' perspectives may also be a result of restricted access for journalists and civil society organizations to detention facilities.

There are two main representations of the theme of 'legislation and legal procedures' when it comes to describing incidents involving deportation detainees: either the article refers to the case of an individual that was taken to court or had undergone the process of applying for asylum, or policymakers gave individual cases of criminal asylum-seekers as reasons for the need to come up with more restrictive laws, including expanding deportation detention. In other words, either the article featured a technical description of the legal procedures related to deportation detention and asylum applications, or it viewed legislation on deportation detention through a political lens, i.e. as a solution reducing crime.

The combination of the portrayal of individual cases of detainees in relation to the topics of violence and crime brings about a multi-faceted picture. Even though most texts refer to cases that involve an asylum-seeker who has committed a crime or misdemeanor, there are also reports on prison guards and prison managers who allegedly abused detainees. An illustrative example for the link between cases and crime as most frequently portrayed in the analyzed articles is an assessment presented by Berliner Zeitung:

Ilyas A. had been in jail. He had not been transferred to deportation detention after he had finished his jail time. This was for a very simple reason: the governing Red-Red-Green Senate wanted to abolish deportation detention. In October 2016, the Social Democrats, the Left Party and the Greens agreed that deportation detention was an 'inadequate measure' and should not be applied any longer. This is why Ilyas A. was released and this is also why Mahmut A. was released from prison. If both had been deported, Susanne Fontaine had not been strangled and Than N. had not been stabbed to death.

(Schupelius 2018)

Another example is Neue Westfälische's article on more restrictive practices inside the detention facility in Büren, North Rhine-Westphalia, as a 
consequence of terrorist threats and a rising number of convicted asylumseekers awaiting deportation:

Prosecutors' offices and Immigration Authorities now inform more systematically about so-called 'threats to public security' [Gefährder]. If possible, refugees with a criminal past do not remain at large any longer but are moved to the only deportation detention facility in Büren.

(Finke 2018)

Interviewees shed more light on this finding. All of the interviewed representatives of civil society organizations emphasized that it is crucial to understand that deportation detention is not ordered because a migrant has necessarily committed a crime. Legally, deportation detention is treated solely as means to an end to enforce the measure itself: deportation. However, several interviewees mentioned that this important differentiation was neither well known among the public nor among the media. According to interviewees, journalists and politicians often reinforced the wrong assumption that migrants held in deportation detention facilities were also criminals.

An example showing a different representation of an incident inside a deportation detention facility that involved violence and crime is an article published by Neues Deutschland, a newspaper with socialist leanings. It covers a court case involving prison guards who had allegedly abused and injured detainees:

A man was forced to lay down on a mattress full of sick while being threatened; moreover, photos of torture scenes. The prosecutor's office accuses the 30 defendants, mostly security guards, of several crimes such as bodily injury, coercion, theft and deprivation of liberty in 54 cases.

(Weiermann 2018)

A closer look at the policies and political struggles addressed in the articles reveals a wide range of topics: new legislative initiatives, the expansion of deportation detention facilities, background information on deportation detention, as well as fundamental rights concerns are raised in the context of policy and politics related to deportation detention in Germany. References to legislation and legal procedures as well as information on the number of detainees held in deportation detention can to some extent be expected since policies often result in, or are accompanied by, legislative efforts and are corroborated by statistics and contextual information. However, the other two thematic categories are less obvious, and yet all the more telling. When it comes to expanding the capacities of deportation detention facilities, articles predominantly refer to state level efforts in Saxony, Schleswig-Holstein, Bavaria and North Rhine-Westphalia to create new deportation detention facilities as well as the political debates emerging around these plans. 
Remarkably, news articles do not discuss any national efforts to expand deportation facilities. Even though deportation detention is a competence of the states, the national trend towards more detention places as laid out in the 'Migration Masterplan' is only highlighted by one article. In the context of Bavaria, deportation detention constituted a hot topic during the state elections. In those articles referring to Bavarian election campaigns, references to plans related to the expansion of deportation detention facilities often contain quotes of politicians promising more detention places, and greater efforts to enforce deportations.

When focusing on the concerns of fundamental rights brought up in the articles, a diverse picture emerges: on one hand, human rights concerns come up in the context of political exchanges in state parliaments over more restrictive deportation detention policies. On the other, we find expert assessments of current deportation detention policies and practices. Beyond this, news articles cite civil society organizations which criticize legislative proposals or the enforcement of legislation in light of fundamental rights concerns. Following up on these critiques, the interviewed representatives of civil society organizations reiterate their concerns that when it comes to deportation detention orders, public agencies do not live up to their obligations as representatives of the constitutional state. On the contrary, all interviewees raise concerns as to the low quality of the decisions regarding procedural requirements and respect for asylum-seekers' rights.

As for political debate, the following quote from an article of Kieler Nachrichten referring to a much-addressed legislative proposal put forward by the government coalition in Schleswig-Holstein, appears in several other news reports:

The oppositional SPD [Social Democrats] strongly criticized the planned facility as well as the changed legislative proposal. Schleswig-Holstein had successfully enforced deportations without a deportation detention facility, in a way that 'the principles of humanity and human dignity could be ensured,' said the speaker of the faction in matters concerning refugees, Serpil Midyatli. The coalition of CDU, Greens and FDP [Free Democrats] was evidently ready to 'sacrifice essential aspects of the humane refugee policy of the state'.

(Unknown 2018a)

The example below highlights a different manifestation of fundamental rights concerns in relation to policy. Here, a lawyer explains the legal implications of the way deportation detention is set in national and state laws:

The provisions for deportation detention are generally so broad that you could detain someone just because he illegally entered Germany. If there's another additional ground, this would quickly become proportional, then he would be put into deportation detention. Bavaria is 
currently a prime example that the provisions for deportation detention are interpreted in an extremely broad way, and that public authorities and courts judge extremely leniently on those applications.

(Barenberg 2018)

\section{The value dimension: the many faces of the rule of law}

The search for values in the reviewed articles resulted in the identification of six overarching value categories which I then assigned 26 values emerging from and repeated in the articles (see Table 7.1). 'Values' - as referred to in my analysis of articles addressing deportation detention - encompass a) all explicit references to values in the context of deportations and deportation detention and asylum-seekers, and b) all ideas on what deportation detention as well as the policies hereof should look like, and how these ideas should be achieved. The overarching categories as derived from the articles are: Political interests, Respect for (fundamental) rights, Democratic principles, Effectiveness and efficiency of deportation detention, Solidarity with asylumseekers/detainees and Moral claims.

Out of the six categories of 'Values,' 'Democratic principles' (126) is the one that appears the most in the articles, followed by 'Respect for (fundamental) rights' (116). Among the values referred to, 'Rule of law' from the 'Democratic principles' category is raised by far the most often, followed by 'Combatting crime' from the 'Political interests' category (36).

Across all articles, references to the rule of law most frequently appear in conjunction with claims regarding the need to uphold a strong, resilient state on one hand, and on the other in the context of the right to an effective remedy for asylum-seekers to appeal their deportation decision and to prove their eligibility for asylum. But the rule of law also comes up in the context of the right to freedom or in relation to the notion that deportation detention is an inadequate or unjustified measure. An example from Berliner Zeitung which brings up the shift in policy, criticizes that deportation detention had once been on the verge of abolition:

In October 2016, the SPD, the Left Party and the Greens agreed per contract that deportation detention was an 'inadequate measure' and should not be enforced any longer.

(Schupelius 2018)

The rule of law is also a reoccurring motif in the interviews. Interviewees from civil society organizations and lawyers stress that rule of law and the constitutional state are at stake where state agencies and courts treat asylumseekers without adequate considerations for due process and without respecting their rights. Criticizing the high number of flawed deportation decisions overturned by higher courts, interviewed stakeholders advocating for the rights of migrants in deportation detention refer to their motivation 


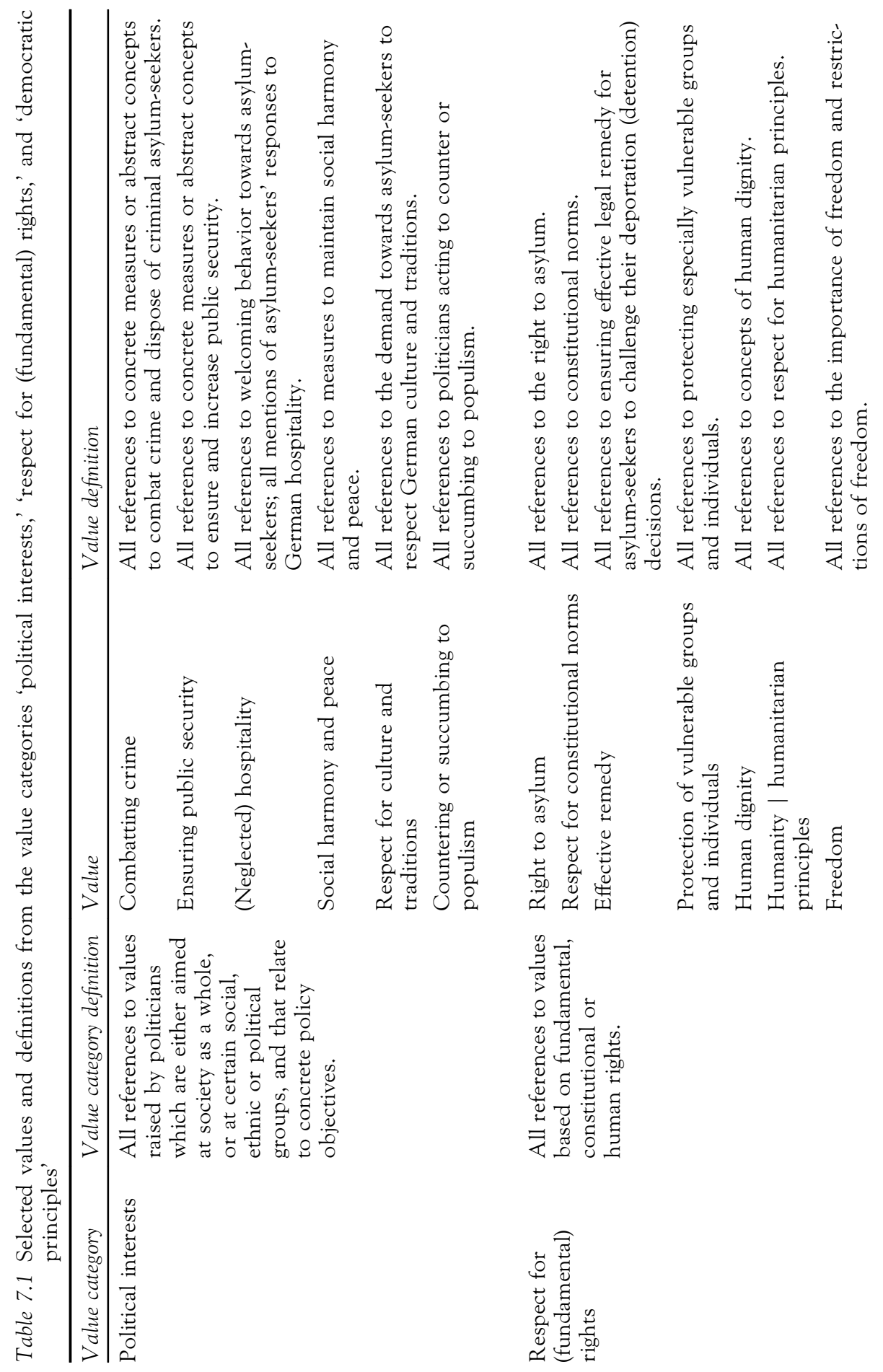



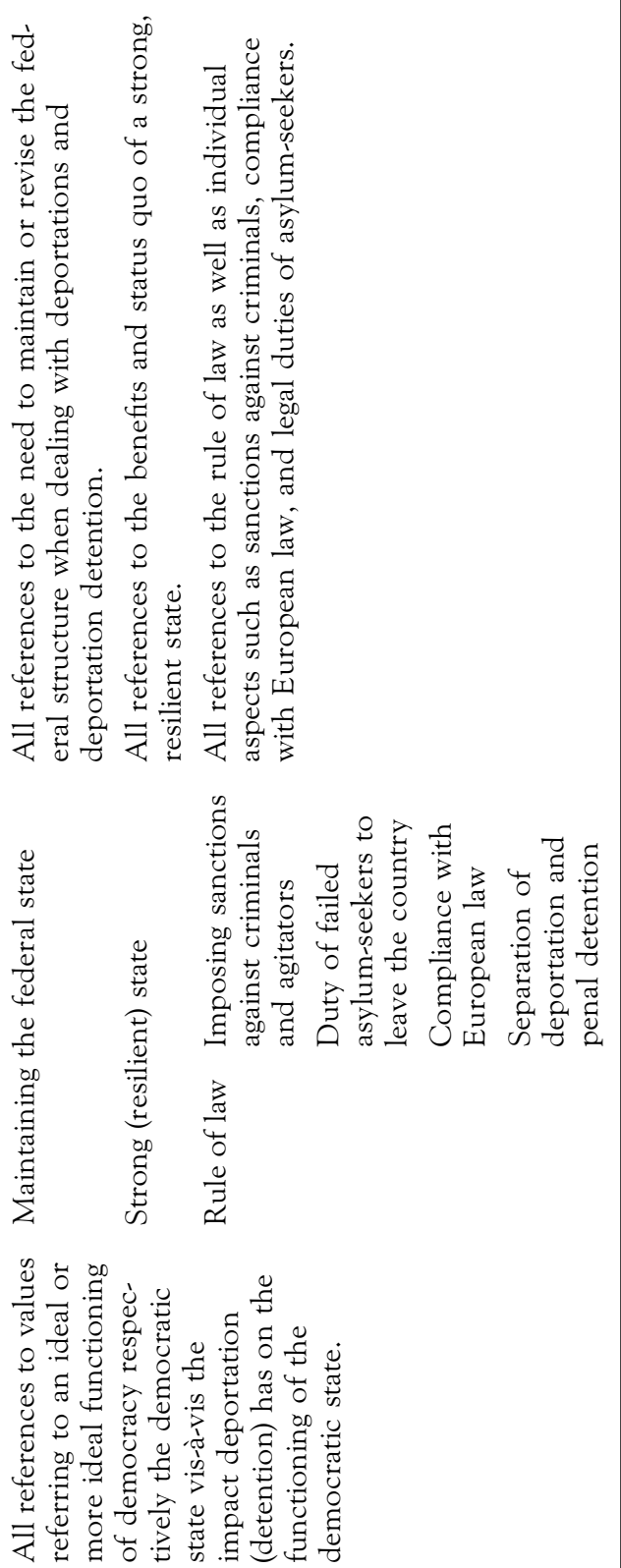

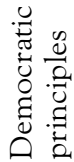


as the desire to uphold justice, and to ensure that detained migrants' voices are heard, and their rights respected. ${ }^{4}$

In almost all cases where an article referred to the duty of refused asylumseekers to leave the country, the author cited a politician arguing that the need to establish more restrictive policies aimed at better enforcement of the rule of law arose as a result of asylum-seekers not leaving voluntarily after their application had been rejected. Moreover, notions of the duty of failed asylum-seekers to leave the country often appeared in conjunction with references to the need for Germany to appear as a strong, resilient state committed to its constitutional values. The subsequent example from Fehmarn24, a North German news portal, illustrates this link:

Speaking for the FDP the speaker of the faction in matters concerning domestic policy, Jan Marcus Rossa, said that creating deportation detention facilities was not a political goal of his party. 'Unfortunately, we are forced to do so if we want to enforce our constitutional state.' It would be better if persons obligated to leave the country left Germany voluntarily.

(Unknown 2018b)

Several articles also cite politicians who spoke of a group of convicted refused asylum-seekers to underline their point that the state needed to act more strongly in enforcing deportations to maintain public order and the rule of law. It should be noted that the majority of the articles addressing this nexus comes from the months May and June when a tumultuous incident in the Ellwanger reception facility for asylum-seekers had occurred, and several acts of violence were reported from the deportation detention facility in Büren. This example from Fürther Nachrichten in Bavaria illustrates the link between convicted asylum-seekers, enforcing the rule of law and upholding the image of a strong, resilient state:

[Mayor] Jung pressed for eliminating this 'gap in law', among others in a letter to SPD party leader Andrea Nahles. It couldn't be that criminals who were obliged to leave the country could force their stay. The state's options to sanction were too weak. In the case of lacking cooperation, deportation detention had to be made available more quickly.... A constitutional state, said the mayor, had to be measured against its power to enforce the law.

(Unknown 2018c)

Where the rule of law was brought up in conjunction with the assessment that deportation detention was an inadequate measure, most articles cited politicians criticizing deportation detention on the basis of flawed legal procedures. 
Jelpke criticized the ignorance in this area [cases of unlawful deportation detention]: It was telling that unlawful deportation detention was not systematically recorded. 'Who doesn't record their own mistakes, doesn't have to deal with those mistakes,' said the politician. 'Evidently, refugees' rights to freedom mean so little to German authorities that they readily accept their unlawful detention - if that serves the better enforcement of deportations.'

(Kastner 2018)

\section{A great cluster of values, a small consortium of value agents}

The examples above highlight one key finding: as portrayed by the media, politicians represent one main group of value agents - if not the most dominant one - in the context of deportation detention in Germany, irrespective of whether they are for or against it. Even though this group is very diverse in its positions depending on their political affiliation and whether they are part of the government (coalition) or of the opposition, the analyzed articles reveal similarities in the values politicians refer to. The second influential group is also fairly heterogenous and consists of civil society organizations such as the Jesuit Refugee Service, various Refugee Councils and locally active non-governmental organizations like 'Help for People in the Deportation Detention Center Büren' (Hilfe für Menschen in Abschiebehaft Büren). Other important value agents as portrayed by the media are official monitoring institutions, such as the National Agency for the Prevention of Torture, as well as lawyers and law firms.

Table 7.2 Value agents shaping the debate about deportation detention

\begin{tabular}{|c|c|c|c|}
\hline $\begin{array}{l}\text { Main } \\
\text { Category }\end{array}$ & Definition & Sub-Category & Definition \\
\hline \multirow[t]{4}{*}{ Value Agents } & \multirow{4}{*}{$\begin{array}{l}\text { All mentions of } \\
\text { individuals and/ } \\
\text { or organizations } \\
\text { and/or institu- } \\
\text { tions active and } \\
\text { influential in the } \\
\text { context of depor- } \\
\text { tation detention } \\
\text { which promote } \\
\text { specific (sets of) } \\
\text { values. }\end{array}$} & $\begin{array}{l}\text { Civil Society } \\
\text { Organizations }\end{array}$ & $\begin{array}{l}\text { All references to actors from } \\
\text { non-governmental, civil society } \\
\text { organizations. }\end{array}$ \\
\hline & & Politicians & $\begin{array}{l}\text { All references to policymakers } \\
\text { from federal, state and local } \\
\text { levels. }\end{array}$ \\
\hline & & $\begin{array}{l}\text { Monitoring } \\
\text { institutions }\end{array}$ & $\begin{array}{l}\text { All references to public institu- } \\
\text { tions in charge of monitoring } \\
\text { human rights compliance, } \\
\text { including courts. }\end{array}$ \\
\hline & & $\begin{array}{l}\text { Lawyers | } \\
\text { Law firms }\end{array}$ & $\begin{array}{l}\text { All references to legal profes- } \\
\text { sionals and law firms promot- } \\
\text { ing and defending the rights of } \\
\text { deportation detainees. }\end{array}$ \\
\hline
\end{tabular}


The three values the different groups of value agents refer to the most are: upholding the rule of law (57), the need to combat crime (28) and complying with humanitarian principles (22). It is however worth exploring less frequently addressed categories such as the appeal to solidarity with asylumseekers (14), the appeal to protecting vulnerable groups and individuals (12) and the notion of countering or succumbing to populism (7).

A closer look at the text sections coming up when looking at value agents discussing how to combat crime in the context of asylum-seekers, reveals that in most cases, politicians or police officials tie these two topics together. Where civil society organizations appear, it is mostly to urge caution when using convicted asylum-seekers as a reason for more restrictive deportation (detention) policies. Interestingly, civil society organizations - and the same holds true for lawyers, law firms and monitoring institutions - exclusively feature as opponents of politicians or facility staff and police demanding an expansion of deportation detention facilities, or critics of legislative proposals allowing for a more liberal use of the instrument of deportation detention.

None of the articles features non-governmental organizations which support the instrument of deportation detention. Interviewees from civil society organizations shed light on this observation: they state that NGOs active in this thematic area are scarce and often barely connected. Moreover, attempts to build a national network are still in the early stages. According to interviewees, civil society usually organizes around a local detention facility aiming to help the detainees inside. Hence, when consulted for news articles, NGOs predominantly featured as a balancing voice contrasting politicians' views on the benefits of expanding deportation detention. Interviewees partly reiterated this view during the interviews: The majority of interviewed stakeholders stressed that while they generally advocated for an abolition of deportation detention, their main concern was that where there had been a detention order the decision complied with all legal, procedural standards and respected the rights the constitutional state had given to every individual. As one interviewee put it:

The people who are pro deportation detention keep saying that we must preserve the rule of law; but they always refer to the constitutional state as the state that must enforce the law against the weaker members of society. However, rule of law also means that we must protect the weakest; and that doesn't happen. We established rules and now we don't play the game according to them.

Arguments linking value-based statements on combatting crime to asylumseekers are usually raised by politicians and based on references to specific cases of migrants who committed a crime. Here, again, the lack in differentiation between the purpose of deportation detention and criminal punishment is manifested. The following value-based statements - one from an article in Frankfurter Rundschau and the other from an article of BILD - are examples of how refused asylum-seekers, crime, and deportation detention 
are interlinked by politicians and public authorities as portrayed in the analyzed articles:

The South-Hesse police president Bernhard Lammel, whose department is in charge of the new deportation detention facility in Darmstadt, has recently made a different impression. He told the local press: 'The focus is on those who don't comply with our law.' It couldn't be conveyed to citizens that people who commit crimes are permitted to stay.

(Bebenburg 2018)

[The Berliner] CDU-faction leader Burkard Dregger (54) raises concerns. He points to individual felons among the asylum-seekers: 'They are dangerous. A person like the Tiergarten-murderer of Susanne F. should have been in deportation detention after committing that crime.

(Unknown 2018d)

Finally, the group of politicians demands further differentiation. Generally, the Left Party, the Greens and in some cases the SPD are portrayed as fierce critics of the concept and the instrument of deportation detention. Yet, where the Greens are part of the government (coalition) like in Schleswig-Holstein or Baden-Wurttemberg, representatives of the party appear less morally condemning in the articles. Instead, they stress the need to increase the number of persons returning to their countries of origin and describe deportation detention as a necessary means to that end. Furthermore, the vast majority of statements cited from Bavarian politicians vehemently advocate for more places in deportation detention facilities and a more liberal use of the instrument of deportation detention. While this is an important finding, it must be noted that the sampled articles are from a period of time that overlaps with the Bavarian state election, which included immigration and asylum-seekers as key topics.

An assessment repeated throughout the interviews helps grasp the context of the debate on deportation detention in Germany: positions on deportation detention have increasingly become a yardstick clarifying a politician's leaning within the overarching debate on the future of German asylum policy. Deportation and deportation detention have, therefore, become the prism breaking up a wide range of political interests and goals, reaching from regulatory and security-related considerations, preserving social welfare, combatting crime and living up to international obligations to the promotion of human rights.

\section{The invisible European dimension}

The ongoing revision processes concerning the Common European Asylum System (CEAS) and more specifically, the Dublin III Regulation and the 
Return Directive, promise to amend the list of potential grounds for deportation detention and generally appear to follow a considerably more restrictive approach. The European Commission, in the memorandum of the latest draft of the Return Directive, announced that the proposal aimed to 'ensure a more effective use of detention to support the enforcement of returns' (European Commission 2018: 3). The Commission furthermore explained that 'there is need for targeted changes in the rules on detention. Firstly, new risks have emerged in recent years, which make it necessary that illegally staying third country nationals who pose a threat to public order or national security can be detained if deemed necessary' (European Commission 2018: 8).

In the sampled articles, the European context (16) is not frequently brought up. When it is, it always appears in the form of references to European law or case-law of the Court of Justice of the European Union (CJEU) or the European Court of Human Rights (ECtHR). Most often, articles refer to a judgment of the CJEU prohibiting the joint detention of convicted felons and migrants awaiting deportation. The following example stems from an article of Berliner Morgenpost:

Three years ago, the former deportation detention facility in BerlinGrünau had been closed. So-called 'Gefährder' [person posing a threat] had been temporarily detained in a part of the jail in Tegel prior to their deportation. But the EU stipulates that deportation detainees must be detained in a separate facility, kept away from criminals, as the Senate administration said on Friday.

(Unknown 2018e)

None of the articles discusses the legislative proposals on revising the major European instruments to regulate deportation detention: the Dublin III Regulation and the Return Directive. This is starkly contrasted by the results from the interviews: all representatives of civil society organizations stress the importance of these legislative processes for the practice of deportation detention in Germany and raise concerns that the current drafts will result in a more liberal use of deportation detention.

\section{Conclusion}

The analysis of 139 articles, as well as complementary expert interviews, aimed to shed light on the question of which values dominated public discourse regarding deportation detention, and which value agents were promoting them. Six groups of values containing a total of 26 sub-category values were identified, of which 'Democratic principles' and 'Respect for (fundamental) rights' are the value categories most frequently referred to. The way value agents raised these values, however, differed considerably. While in the analyzed articles politicians would bring up the 'Rule of law' mostly to argue that deportation detention was necessary to ensure the 
functioning of the constitutional state, civil society organizations referred to the 'Rule of law' when criticizing unlawful deportation detention.

When specifically examining value agents and the values they brought up, a strong divide among groups of value agents becomes apparent. While references to exercising solidarity with asylum-seekers are barely found among politicians; lawyers and civil society organizations dominate this value category. The picture changes when exploring the references to the need to combat crime or ensure public safety, which are defined by politicians' statements.

Generally, it is remarkable how frequently deportation detention is discussed in regard to specific cases of detainees, rather than at a more abstract policy level. In this context, it is even more noteworthy that the voices of (former) deportation detainees are almost never featured in the analyzed articles. Experts from civil society offer two explanations for this finding: on one hand, access to deportation and reception facilities is extremely limited. On the other, public awareness of the specific legal requirements of deportation detention - migrants in deportation detention do not need to have committed a crime - is very limited and therefore, there is no broad interest to listen to deportation detainees' side of the story. In fact, all interviewees stressed how small a community the circle of experts on deportation detention is.

Lastly, even though neglected in media articles, according to interviewees the European level strongly affects national policies on deportation detention which otherwise is a competence of the German federal states. Governance structures are therefore complex with a multitude of stakeholders involved. Experts expect the currently ongoing revision of the Dublin Regulation as well as the Return Directive to have considerable impact on the German practice of deportation detention; likely, pushing it towards a more restrictive approach.

The complexity of this policy area is mirrored by the different sets of values raised in the context of deportation detention. While the majority of identified values broadly refers to structures of the state or society, only one set of values (solidarity with asylum-seekers and detainees) addresses detained migrants directly. Furthermore, divergent interpretations of the same values, for instance upholding the rule of law, complicate communication efforts between the different groups of value agents who seem to hold value-based, and therefore hardly negotiable, positions.

The trend towards a more restrictive asylum policy in Germany goes hand in hand with an expansion of legal grounds for ordering deportation detention, as well as the establishment of further detention facilities. The overview of values surfacing as part of the debate on deportation detention has foregrounded the fact that values in the context of deportation detention seem to be closely tied to an idea of a troubled constitutional state that must find its way back to and show its strength by strictly enforcing the rule of law, and thus deportations; or otherwise, risk unsettling societal peace and compromising public security. This development speaks to the overarching shifts in 
the socio-political climate in Germany: from the country of 'refugees welcome' to a highly polarized nation fearful that more migration will lead to an ever-greater divide in society. ${ }^{5}$

\section{Notes}

1 Across different literatures, the German term "Abschiebungshaft" has also been translated as immigration detention, migrant detention, pre-expulsion detention, removal detention, and detention pending removal. However, in order to attempt a literal translation that also demarcates the concept as clearly as possible I use the term "deportation detention".

2 For more on the sampling process, see for instance Newbold et al. (2002: 63 and 80 f.), Macnamara (2005: 3; 13 and 18); Patton (2002: 230 ff.) or Krippendorff (2004: $111 \mathrm{ff}$.

3 'Bavaria's prime minister': a category emerging as a consequence of the Bavarian state election that featured asylum-seekers and related subjects as key topics.

'Protests in Ellwangen': The reception centre for asylum-seekers in Ellwangen made headlines because of a violent incident between the police and residents of the centre.

'Munich airport': This tag showed up in relation to the new detention facility at Munich airport.

4 According to the Federal Office for Migration and Refugees, in 2018, 17.1 percent of all court decisions where issued in favor of the complainants. In 2017, this number had been 22 percent (Federal Office for Migration and Refugees 2019).

5 See for instance the Friedrich Ebert Foundation's (2019) survey on Germans' perceptions of migration.

\section{References}

Barenberg, J. (2018). 'Forderung nach Gesetzesverschärfung ist "Schaufensterpolitik",' Deutschlandfunk, 5 May 2018. Available at: www.deutschlandfunk. de/anwalt-zu-abschiebehaft-forderung-nach.694.de.html?dram:article_id=417257

Bebenburg, P. (2018). 'Straffälligkeit spielt für Abschiebehaft keine Rolle,' Frankfurter Rundschau, 26 June. Available at: www.fr.de/rhein-main/die-linke-org26318/straffa elligkeit-spielt-abschiebehaft-keine-rolle-10986963.html

CDU, CSU \& SPD (2018). Ein neuer Aufbruch für Europa. Eine neue Dynamik für Deutschland. Ein neuer Zusammenhalt für unser Land, 6 March. Available at: www. cdu.de/system/tdf/media/dokumente/koalitionsvertrag_2018.pdf?file=1

Directive of the European Parliament and of the Council on common standards and procedures in Member States for returning illegally staying third-country nationals (recast) (COM(2018) 634 final) (2018). Official Journal of the European Union.

Entwurf eines Zweiten Gesetzes zur besseren Durchsetzung der Ausreisepflicht (2019). (Geordnete-Rückkehr-Gesetz), German Federal Government, Berlin.

European Commission (2018). Proposal for a DIRECTIVE OF THE EUROPEAN PARLIAMENT AND OF THE COUNCIL on common standards and procedures in Member States for returning illegally staying third-country nationals (recast), 12 September. Available at: https:/ec.europa.eu/commission/sites/beta-political/files/soteu2018-r eturning-illegally-staying-third-country-nationals-directive-634_en.pdf

Federal Ministry of the Interior (2018). Masterplan Migration. Bundesministerium des Innern, 4 July. Available at: www.bmi.bund.de/SharedDocs/topthemen/DE/top thema-masterplan-migration/topthema-masterplan-migration.html 
Federal Office for Migration and Refugees (2019). Gerichtsstatistik 2018, BAMF, 28 March. Available at: www.bamf.de/SharedDocs/Meldungen/DE/2019/20190328-ger ichtsstatistik-2018.html?nn=1367522

Finke, K. (2018). 'Bedingungen in Bürener Abschiebehaftanstalt werden verschärft,' Neue Westfälische, 3 October. Available at: www.nw.de/lokal/kreis_paderborn/bueren/ 22259912_Bedingungen-in-Buerener-Abschiebehaftanstalt-werden-verschaerft.html

Friedrich Ebert Foundation (2019). Umfrage: Was die Deutschen über Migration denken. FES, 19 March. Available at: www.fes.de/themenportal-flucht-migration-integra tion/umfrage-was-die-deutschen-ueber-migration-denken

Gesetz über den Aufenthalt, die Erwerbstätigkeit und die Integration von Ausländern im Bundesgebiet (2017). (Aufenthaltsgesetz - AufenthG), Bundesgesetzblatt, Bonn.

Gesetz zur besseren Durchsetzung der Ausreisepflicht (2017). Bundesgesetzblatt, Bonn.

Gockel, F. (2019). 100 Jahre Abschiebehaft. Available at: http://100-jahre-abschiebehaft. de/de/startseite

Judgments in Joined Cases C-473/13 and C-514/13 and in Case C-474/13 Adala Bero v Regierungspräsidium Kassel, Ettayebi Bouzalmate v Kreisverwaltung Kleve and Thi Ly Pham $v$ Stadt Schweinfurt (2014), Court of Justice of the European Union, Luxembourg.

Kastner, B. (2018). 'Einsperren, rauswerfen,' Süddeutsche Zeitung, 22 November 2019. Available at: www.sueddeutsche.de/politik/asyl-einsperren-rauswerfen-1.4222389

Keßler, S. (2019). 'Abschiebungshaft,' Socialnet Lexikon, 14 January. Available at: www.socialnet.de/lexikon/Abschiebungshaft

Krippendorff, K. (2004). Content Analysis. An Introduction to its Methodology. Thousand Oaks, CA: SAGE Publications.

Macnamara, J. (2005). 'Media content analysis: Its uses; benefits and best practice methodology,' Asia Pacific Public Relations Journal 6(1), pp. 1-34.

Neuendorf, K. A. (2002). The Content Analysis Guidebook. Thousand Oaks, CA: SAGE Publications.

Neuendorf, K. A. (2017). The Content Analysis Guidebook, 2nd edn. Thousand Oaks, CA: SAGE Publications.

Newbold, C., Boyd-Barrett, O., \& van den Bulck, H. (2002). The Media Book. London: Arnold.

Pany, T. (2016). Merkel: Rückführung, Rückführung und nochmals Rückführung. Heise, 1 September. Available at: www.heise.de/tp/features/Merkel-Rueckfuehrung-Rueckfu ehrung-und-nochmals-Rueckfuehrung-3312398.html

Patton, M. Q. (2002). Qualitative Research and Evaluation Methods, 3rd edn. Thousand Oaks, CA: SAGE Publications.

Unknown (2016). 'Merkel für konsequentere Abschiebungen,' Zeit, 15 October. Available at: www.zeit.de/politik/deutschland/2016-10/angela-merkel-rede-deutschla ndtag-der-jungen-union-paderborn-asylbewerber

Unknown (2018a). 'Kabinett billigt Gesetzentwurf,' Kieler Nachrichten, 11 September. Available at: www.kn-online.de/Nachrichten/Politik/Kiel-Kabinett-billigt-Ge setzentwurf-ueber-den-Vollzug-der-Abschiebungshaft

Unknown (2018b). 'Neues Gesetz für Abschiebehaft,' Fehmarn24, 22 May. Available at: www.fehmarn24.de/schleswig-holstein/innenministerstellt-entwurf-einrichtung-glueckstadt-9890352.html

Unknown (2018c). 'Abschiebehaft: Fürths OB Jung fordert Hilfe von Nahles,' Fürther Nachrichten, 21 November. Available at: www.nordbayern.de/region/abschiebeha $\mathrm{ft}$-furths-ob-jung-fordert-hilfe-von-nahles-1.8327413 
Unknown (2018d). 'Warum schiebt Berlin so wenig ab?' Bild, 7 November. Available at: www.bild.de/regional/berlin/berlin-aktuell/abgelehnt-und-doch-noch-da-warum -schiebt-berlin-so-wenig-ab-58270634.bild.html

Unknown (2018e). 'Neues Abschiebegefängnis für Kriminelle und Gefährder,' Berliner Morgenpost, 21 September. Available at: www.morgenpost.de/berlin/article215384143/ Neues-Abschiebegefaengnis-fuer-Kriminelle-und-Gefaehrder.html

Rokeach, M. (1979). Understanding Human Values. Individual and Societal. London: Collier Macmillan Publishers.

Schreier, M. (2013). 'Qualitative content analysis,' in Flick, U. (ed.) The SAGE Handbook of Qualitative Data Analysis. Thousand Oaks, CA: SAGE Publishing, pp. $170-183$.

Schupelius, G. (2018). 'Späti-Mörder nicht abgeschoben. Justizsenator verweigert Auskunft!' Berliner Zeitung, 12 January. Available at: www.bz-berlin.de/berlin/ kolumne/spaeti-moerder-nicht-abgeschoben-justizsenator-verweigert-auskunft.

Weiermann, S. (2018). 'Demütigungen, Schläge und Gefangenschaft,' Neues Deutschland, 8 November. Available at: www.neues-deutschland.de/artikel/1105283.gewa lt-gegen-gefluechtete-demuetigungen-schlaege-und-gefangenschaft.html. 


\title{
8 Integration by contract and the 'values of the Republic'
}

\author{
Investigating the French State as a value \\ promoter for migrants (2003-2016)
}

Myriam Hachimi Alaoui and Janie Pélabay

\section{Introduction}

This chapter deals with immigrant integration policies developed over the past two decades in France. It focuses on integration contracts, which aim to ensure public promotion of the 'values of the Republic' among newcomers eligible for residence permits, whether they be migrants or refugees. These programs are part and parcel of the 'civic turn' (Mouritsen \& Jørgensen 2008) in immigration and integration policies implemented in a variety of European countries from the late 1990s onwards. Consistent with public discourses on the failure of multiculturalism and the related need for a 'muscular liberalism' (Cameron 2011), the desire to return to 'thick' ${ }^{1}$ conceptions of integration (Etzioni 2011; Walzer 1994) and indeed to policies that focus on assimilation (Brubaker 2001; Honohan 2016) has developed in many parts of Europe. Such desire as well as the parallel concern about consolidating national identities are notably visible in the development of citizenship trajectories and training sessions within the framework of migration policies designed to foster a thick integration into the broader society, and subsequently, to strengthen the conditions for granting residence permits.

Although there are differences between these programs, they all share a common public purpose: to promote the core values declared to be the substantive foundation of the political community. Such a public aim is consistent with the emphasis placed on 'shared values' by the European Commission and the Council of Europe in the 2000s (Pélabay 2011a), and with the multiplication of civic education policies dedicated to the inculcation of the values shared by 'good citizens' (Kostakopoulou 2010; Pélabay 2011b). What emerges as a true politics of common values reveals a growing distrust of the celebration of diversity broadly criticized for its fragmentary effects on the society as a whole. It also implies an ongoing moral and/or cultural 'thickening' of citizenship. In the European context, national integration policies are then developed with two main objectives: to condition the process of integration itself, notably through its contractualization, and to pave the way for state promotion of the 'values' of the host society. Taken 


\section{M. Hachimi Alaoui and J. Pélabay}

together, these two objectives lead to a conception of integration where respect for 'values' placed at the heart of the 'us' are imposed on 'others' as a constraint included in a contract between foreigners and the State.

In France, such contractual value-based integration has been implemented through a series of programs such as the Contrat d'Accueil et d'Intégration (CAI), drafted in 2003, its family reunification counterpart, the Contrat d'Intégration pour la Famille (CAIF), developed in 2007, and the more recent Contrat d'Intégration Républicaine (CIR) which replaced both of the former in 2016.

In this chapter, we will investigate the French State as a value promoter by focusing on the Contrat d'Accueil et d'Intégration and the Contrat d'Intégration pour la Famille. Our analysis is based on a field survey carried out between 2012 and 2015 that includes fifteen observations of one-day training delivered within the framework of these two contracts. Thirteen of these training days were delivered in two training centers in Paris and the remaining two in Lille. These observations were complemented by in-depth interviews with five trainers, a number of informal interviews with attendees, and eight policy-makers. In addition to these data, our study builds on a content analysis of documents and communication tools related to integration contracts, notably the forms that must be signed, and the civic training PowerPoint; as well as discourse analysis of a number of institutional reports and statements made by political elites.

On this basis, the chapter examines the rationale behind the implementation of the two contracts, the manner in which the 'values of the Republic' are publicly articulated and inculcated to incoming migrants and refugees, and the tensions that emerge from such a republican politics of common values. Finally, we will ask whether the French 'republican values' discourse and practice may - just like European ones - lead both to the homogenization of the majority identity and to the exclusion of minority identities considered as embodying value systems which are not only different but also opposed to 'ours.'

\section{A climate of civic anxiety about the survival of the 'Republican model'}

The background to the launch of the Contrat d'accueil et d'intégration (CAI) in 2003 was colored by a growing sense of anxiety about social cohesion (Helly 2009; Holtug \& Mason 2010), immigration, and Islam - three questions which have been continually present and combined in public debate in France since the 2000s. Their combination is incarnated by a term: communitarianism. In itself, this term seems to encapsulate all French anxieties (Dhume-Sonzogni 2016), in particular the fear that the so-called 'French model of integration' could disappear under the effect of the 'Anglo-Saxon'style politics of minority rights. Hence the need to promote the 'values of the Republic' as a remedy to the cultural fragmentation of the society, and to reaffirm them in a contract that binds foreigners to the State. In this respect, 
the CAI was conceived as a means to reaffirm that the French model alone can resist communitarianism. As declared by François Fillon when he was Minister for Social Affairs in 2002: 'Living in France means choosing France together with its duties and ideals. Our country is not merely a geographical area ... it has chosen integration over communitarianism' (Tabet 2002).

During this same period, pessimistic views that supported the affirmed need to revive more 'robust' integration policies multiplied. This resulted in a call for policies that were very demanding of foreigners with regard to respect for the collective identity that would supposedly guarantee the unity and indeed the integrity of the Republic. A number of events then contributed to a solid reinforcement in public discourse of phrases such as 'broken down integration,' 'a weakening of national sentiment,' and 'the Republic's values under threat,' all of which acted as signposts for a return to assimilation. This phenomenon explains the successive controversies surrounding the "veil' which led to a law banning the wearing of religious symbols in schools in 2004. To this, we must add the 2005 suburban riots, which were analyzed in public debate through the prism of Islam (Tiberj 2014) and erected into a powerful symbol of the integration crisis (Fassin \& Fassin 2006). Blandine Kriegel (2005), the then president of the Haut Conseil à l'Intégration, said:

The suburban crisis highlights the existence of the sure failure of our integration policy.... For decades, we chose to abandon the very term 'integration' - which has always been controversial - and substituted it for recognition of diversity and the fight against discrimination. These are two necessary actions; however, on their own, they have provided a foundation to communitarianism.

In 2007, the call for integration to be prioritized over respect of differences was oriented towards an identity politics with the creation of the Ministry of Immigration, Integration, National Identity, and Co-development. The ministry subsumed the question of immigration into the question of national identity, as shown by the launch, in 2009, of a 'debate on national identity' designed to answer the urgent need stressed by the then Minister Éric Besson to reflect on 'what it means to be French,' 'the values we share,' 'the nature of the ties which mean we are French,' and on our duty 'to be proud' of what we are (AFP 2009). From that point on, the question of national identity was regularly present on the political scene and ultimately placed the idea of a 'cultural insecurity' among the majority group at the center of debate (Bouvet 2015).

At the same time, the term assimilation, which had disappeared from political vocabulary for a time, reappeared in public discourse. In 2003, the then Prime Minister, François Fillon, pronounced himself to be in favor of 'integration .... and indeed of assimilation' (Zappi 2003). Some years later, in 2010, as advisor to President Nicolas Sarkozy, Henri Guaino (2010) very 


\section{M. Hachimi Alaoui and J. Pélabay}

explicitly advocated for a return to assimilation: 'I am indeed saying assimilation. I am aware that the word upsets some people but for 200 years, assimilation has been the Republic's program.'

These leitmotivs of a crisis in integration and a necessary return to assimilation resurfaced with force following the January 2015 terrorist attacks on the Charlie Hebdo newspaper and the Hyper Casher supermarket, and even more so following November 2015 when Paris became a bloodbath (130 people were killed and more than 400 injured by a group of fundamentalist Islamic terrorists). Unfurled in its symbolic dimension (Faucher \& Boussaguet 2018), the political response of those in power was to wager on a form of patriotism based on the defense of 'our' shared values (Pélabay 2017a).

From the initial launch of the integration contracts - the CAI and the CAIF - to the most recent adjustments to them, this context of civic anxiety about the destabilizing effects of diversity (Macedo 2000) constitutes the background of the movement towards contractual integration.

\section{Contractual integration: the CAI and the CAIF}

The process towards contractual integration started in such a context reveals the strong connection between, on the one hand, the type of rights which foreigners might aspire to and, on the other hand, their individual responsibility for both the success of their integration and the fulfilment of their obligations to the French State and society at large. Thus, a report on the 2003 bill relative to immigration and residence for foreigners in France stipulates for the CAI and the CAIF:

Since integration is defined as including reciprocal rights and duties, it was logical to establish a link between efforts made by new arrivals to make a success of their entry into the society that is hosting them, and the status that the said society confers on them with respect to right of residence.

(Mariani 2003: 22f)

Once a 'tool for integration,' the status of resident has now become a 'reward' for successful integration, as underlined by the law professor Danièle Lochak (2009).

Implemented in 2003 on an experimental basis, the CAI became mandatory as part of the July 24, 2006 law on immigration and integration. The program is intended for immigrants who wish to settle in France on a longterm basis. More precisely, it is for incoming migrants who have been granted their first residence permit and refugees whose status has already been validated in France. It also targets previously undocumented migrants whose situation has been regularized. By signing such a contract, migrants and refugees commit to respecting and living in accordance with the 'values of the Republic.' The latter are listed in the CAI form as follows: democracy, 
the rights and duties attached to the 1789 Declaration of the Rights of Man and of the Citizen, 'laïite' ('secularism'), equality, and the French language. After one year - the usual duration of the contract - a civil servant determines whether migrants have met the contractual requirements by verifying that they attended the training sessions and met the 'Republican integration condition' analyzed below. The non-fulfilment of the contract can be used by the administrative authorities (i.e. the Prefect) to refuse renewal of the residence permit.

The preamble to the CAI summarizes its philosophy as follows: 'Choosing to live in France, means choosing to integrate into the French society and accept the fundamental values of the Republic.' These two types of engagement give meaning to the clauses contained in the contract. While Article 2 of the CAI stipulates that by agreeing to the contract, the foreigners commit to 'diligently' attending the training sessions designed to prepare for their 'integration into the Republic,' Article 1 defines the obligations of the State which, in reality, are limited to delivering the said training sessions. The training is of a varied nature. It includes language training, when this has been deemed necessary following a French language evaluation. Applicants also have the option of an information session on life in France (procedures for everyday life, access to public services such as health, education, etc.) and a skills/competence evaluation if one has been prescribed. Most importantly, all the signatories of the CAI must attend civic training.

The latter is limited to a day-long session lasting eight hours. The civic course is divided into five modules and covers 'the history of France,' the 'values, principles, and symbols of the Republic,' 'institutions of the Republic,' 'French nationality and citizenship,' and finally 'France and Europe.' The accompanying PowerPoint presentation alone contains almost 80 slides. Interviewed trainers and participants agree that the program content is far too packed. As observed during our field survey, the trainers begin the class with explicit reference to the preamble of the contract:

You have committed to following these training sessions, to making the necessary efforts for your integration, and to respecting the values and the principles of the French Republic. France and the French people are attached to a history, a culture, and a set of fundamental values. In order for everyone to live together, you must know them, understand them, and respect them. By committing to respecting the 'values of the Republic,' you will find your place fully in French society. Choosing to live in France means choosing to integrate into the French society.

The text concludes with 'Welcome to France!' written at the bottom of the page; a 'Welcome!' which contrasts with the reality of the participants' experiences, many of whom have been residents in France for many years and who only find themselves obliged to follow these sessions as a result of frequently chaotic legal trajectories. For example, while observing a session 
in Paris, we counted nine participants among the total of 25 who had been in France for at least ten years, one of whom was from the Ivory Coast and had been in France since 1995. 'When I arrived here, Mitterrand was still in power! So yeah, I know France,' he said, and speaking laughingly to the trainer: 'I could even take your place if you want!'

The November 20, 2007 law extended the logic of contractual integration (Hachimi Alaoui 2016) by introducing a second contract, the Contrat d'accueil et d'intégration pour la famille (CAIF), which is added to the CAI and aims to 'prepare families for the republican integration into French society' (Immigration Act $\mathrm{n}^{\circ}$ 2007-1631). This second contract targets spouses and children who came to France as part of the family reunification process. The CAIF contract is concluded between the State and the two spouses who commit to respect the obligation to send their child/children to school and to attend a specific training on the 'rights and duties of parents.' The training is divided into four themes: 'gender equality,' 'parental authority,' 'children's rights,' and their 'schooling.' As is also the case for the CAI, the residence card is only granted after proof of attendance at the training session is furnished.

The 2007 law also demands that candidates for family reunification (aged between 16 and 65) have already ensured that their knowledge of the French language and of the 'values of the Republic' have been evaluated in their home country prior to their arrival. If they fail these tests, the aspiring immigrants must take civic and/or language classes before leaving their country of origin. Here again, they must provide proof that they have done the training in order to be granted a visa, which does not dispense them from signing the CAI on arrival in France (Hachimi Alaoui 2014). This last element - which does not exist anymore - has been interpreted as a sign of a shift from a process-based vision of integration to a vision focused on the 'integrateable' character of migrants and their prior adherence to the values enshrined in the host country. As Éric Fassin (2010: 160-1) writes:

If a person must be, if not integrated, at least suitable for integration before arriving in France, even with respect to private and family life and yet private life is recognized as a right by the French Constitution and by the European Convention on Human Rights - it means that the nation pre-exists before any foreign intrusion. This is about preserving it in its entirety, rather than exposing it to outside influences.

To conclude, it should be noted that within the framework of the March 7, 2016 law on foreigners in France, the CAI and the CAIF were replaced in 2016 by a new contract: the Contrat d'intégration républicaine (CIR). As a result of the introduction of a pluri-annual resident's card, the CIR has been designed to become part of a 'personalized pathway towards republican integration,' in keeping with the objective of ensuring individual 
responsibility. Furthermore, the introduction of this new contract signals a re-centering on three pillars: 1) the declared 'strengthening' of the mandatory civic training, which has been extended to two days, one of them being entirely dedicated to the 'principles and values of the French Republic;' 2) access to employment as a new priority; and 3) a more demanding level of linguistic proficiency. Henceforth, signatories must have completed level A1 (beginner's level) ${ }^{3}$ of language ability to obtain their first residence permit. Once the pluri-annual residence permit expires, migrants are required to have attained level A2 to be granted a permanent residence. While the new contract is characterized by a pragmatic focus, it nonetheless maintains some thicker conditions for being recognized as fully integrated. As the press release that presents the CIR specifies, the foreigners' personal commitment to 'respect the essential values of French society and the Republic' remains of crucial importance for their being able to prove their 'republican integration.'

\section{Mandatory respect for the 'values of the Republic': conditional integration}

From the start, there is an obvious tension between the mandatory signing of these integration contracts and the fact that free will is usually exercised in the decision to sign a contract or not. Moreover, our field survey shows that the mandatory nature of the CAI and the CAIF has weakened the symbolic aspect of signing them, and transformed them into an added administrative formality to obtain a residence permit. Furthermore, a number of authors (Cournil and Depigny 2008; Lochak 2009) postulate that the CAI and the CAIF are one-sided given that the obligations truly weigh on one party only: the foreigner. Indeed, the State obliges migrants to sign a contract according to which the only 'obligations' incumbent on the State are to provide the foreigners with the means to honor the commitments which the State itself subjects them to honoring. These two tensions are amplified by the fact that the CAI and the CAIF are both marked by the same vision of a 'conditional' integration.

The 'Republican integration condition,' which must be met for a residence permit to be delivered, lies at the very heart of the contractual integration process. The 'assimilation condition' is already a legal requirement (Hajjat 2012) for naturalization applicants; the 'integration condition' has now entered legal vocabulary. In the explanatory statement of the 2003 parliamentary bill on controlling immigration, this condition was justified as a means to block communitarianism. In a memo addressed to French Préfets (Prefects) throughout the country, Nicolas Sarkozy, the then Minister of Internal Affairs, explained:

This integration condition is intended to assist you in preventing communities from turning in on themselves by encouraging more vulnerable 
publics, and in particular the women who form part of some of these communities, to become involved in such a program.

(Ministry of Internal Affairs, Internal Security and Local Liberties 2004)

The 'Republican integration condition' was firstly conceived of for residency status and is now a condition for the majority of residence permits.

As seen above, certificates of attendance distributed at the end of each training program provide formal proof that the clauses of the contract have been respected, and is constitutive of the objective dimension of the 'integration condition.' However, this condition includes subjective aspects which prove to be much more difficult to assess, in particular the personal 'commitment' towards the Republic's values and 'willingness' to integrate. And all the more so as the problematic aim of ensuring adherence to these values has been added to, if not substituted for, simply 'knowing' what the 'values of the Republic' are and 'respect' for related rights and duties. With the introduction of this type of discourse relative to personal convictions (Pélabay 2014), there is a real danger that arbitrary decisions will be made about whether the 'Republican integration condition' has been met by the foreigner or not. Indeed, no concrete elements for the Préfet to base their opinions on the foreigner's compliance of this requirement have been established. This holds true even if the 2004 memo invites administrative officials to 'solicit the opinion of the mayor of the foreigner's residential commune, so that he/she might enlighten the official's decision by providing information that illustrates or not the foreigner's willingness to integrate French society.'

As a result, one question remains unanswered: how do préfecture officials go about evaluating such a personal commitment to respect the 'values of the Republic,' and to sincerely adhere to them? There are two difficulties here: on the one hand, the fact that it is clearly impossible to probe individual consciences, and, on the other, the semantically undefined nature of a large number of 'common values.'

In 2011, an inter-ministerial workgroup was set up to define 'Republican values' so that a new version of civic training could be designed. However, the end result of the discussions showed the diversity of approvals and practices among the working group members who had no choice but to find consensus through a process of elimination: republican values 'are not symbols,' 'neither are they covered by the law, which defines lawful or unlawful acts,' and are not the equivalent of 'the main legal, constitutional and international principles.' When the field survey was carried out, one of the female working group members confided in us that the discussions had been very lively: 'it was not easy to come to an agreement even though we were all civil servants specialized in such questions!' 


\section{'Common values': vague language and a potential confusion of genres}

The difficulty highlighted by those in charge of developing and implementing programs designed to reinforce respect for the 'values of the Republic' is more broadly linked to one of the characteristics of the language surrounding common values: its intrinsic vagueness. Indeed, nothing is less clear than the meaning of the 'common values' that are at the heart of public discourse on all political sides. Even when the same 'values' are being talked about, very different and at times competing interpretations are given: major universal principles that underlie the democratic State; legal norms that confer citizen rights and liberties; moral codes and personal convictions that are borrowed from particular visions of the Good and the Bad; the evocation of roots (notably religious ones) and a historical patrimony constitutive of a particular civilizational legacy; habits and customs that have shaped an ethnocultural way of life observed by the majority of the national group (Pélabay 2017b). All of these represent different understandings of the so-called 'common values,' ranked here by increasing moral and/or cultural thickness. They correspond to visions of integration with varying degrees of robustness that consequently reflect varying degrees of 'welcome' extended to diversity.

Clearly, such semantic vagueness has a number of advantages for users of this type of language. It allows them to address a very wide public, while leaving it up to each individual to conjure up their own vision of what constitutes and delineates 'us.' At the same time, simply accepting the undetermined nature of the values is problematic given that the vagueness of the language used goes beyond the discursive level, and, on a practical level, has a real impact on the public policies designed to promote confirmed 'values.' As a consequence, defining what the term 'values of the Republic' signifies in the CAI and the CAIF is of paramount importance.

As stipulated in the contract, the 'values of the Republic' are placed on a legal and political footing and, as seen above, are limited to a few general democratic principles. Nevertheless, with the 'negative' definition offered by the actors involved (i.e. everything that they are not), the term 'values of the Republic' goes beyond the simple framework of rights and legal duties that govern the political order.

In the 2010s, an explicitly identity-based interpretation of integration was predominant in the public discourse that framed the CAI. Gender equality is particularly indicative of this shift from an interpretation based on a principle of justice to an interpretation based on French identity and culture (Hachimi Alaoui 2012). Gender equality is expressed in the CAI as a 'fundamental principle of French society' that is potentially defendable as a legal norm translated into a series of laws. Yet, it is frequently presented to foreigners as a characteristic feature of the collective identity of the French 
people. Thus in 2011, one of the participants in the inter-ministerial group tasked with defining the 'values of the Republic' explained that 'equality between men and women' was 'a national trait linked to the history of France.'

A similar conception, which drew on the authenticity of a national patrimony emerged from the presentation made by Arno Klarsfeld (2012: 7) president of the Office Français de l'Immigration et de l'Intégration Executive Board from 2011 to 2013 - on the language training given within the CAI framework:

Our customs are the fruit of many centuries of shared history together. They represent an overall legacy which we identify with, even if it changes progressively as a result of various influences and the passage of time. ... This France which is nearly unchanging in the arts, in its military strength and in law, is for the most part immensely generous and sometimes - but very rarely - unkind when prejudice that has not yet been eradicated attempts to hurt or stigmatize.

The passages from the 2011 Information Report on nationality law that focus directly on the CAI attach the same importance to the survival of a national tradition, going as far as to show cultural compatibility as a relevant piece of criteria to judge the suitability of candidates applying for residence permits and/or citizenship. In this Report, Claude Goasguen (2011) thus affirmed:

the first vocation of this tool is to guarantee the integration of foreigners who want to remain on French soil for the long term. The objective remains that the new arrivals adopt behaviors that do not infringe on the morals and customs of the host country.

The way the 'values of the Republic' are defined in these statements reveals a tendency to culturalize citizenship and the condition of integration. As we will see now, such tendency has huge consequences for the respect of pluralism and the capacity for inclusion in society.

\section{Value-based integration: the dangers of homogenization and exclusion}

Analysis of how the 'values of the Republic' are used in the CAI and the CAIF shows that both programs are marked by a strong tension between two different, and indeed competing, conceptions of integration: on the one hand, an 'ethical' concept of integration including the stabilization and reproduction of 'the basic ethical orientations of the cultural form of life dominant in [a particular] country,' and on the other hand, a 'political' concept of integration based on respect of the legal norms institutionalized 
through citizenship (Habermas 1998: 225-8). According to the latter, satisfying the aspirations of the majority group that a real or fictional background consensus on particular cultural values might remain untouched, is not a requirement for integrating into the political community. What is required is to act in a way that conforms to the legal norms which apply to all in the same way. This also means that, in themselves, cultural values cannot serve as criteria to decide who is suitable to become a member of the social body and who is not.

This theoretical clarification serves to underline the point that the public strategy of making genuine adherence to the 'values of the Republic' a condition for acceptance and integration into the political community entails a number of risks.

Let us look firstly at the problems caused by the infringement of the State's neutrality, which occurs when the so-called 'values of the Republic' are affirmed as personal convictions about what is good, what is a life worth living, and what kind of behavior leads to a good life. An example of these problems is given by Christian Joppke (2010: 141) when discussing 'citizenship exams' for naturalization: 'an exam that scrutinizes a candidate's inner disposition is problematic, precisely because it transgresses the thin line that separates the regulation of behavior from the control of beliefs.' As Joppke (2010: 142) explains in relation to a German case of interview guidelines issued by the regional government of Baden-Württemberg in September 2005, the 'transgression' here consists of intruding into the inner conscience and violating freedom of thought of applicants who belongs to a particular group - in the case at hand, Muslims since these guidelines targeted nationals from the Islamic League States - whose presumed values were assumed to be contrary to the liberal democratic order. Hence the problem raised by 'repressive liberalism' which is prepared to develop 'illiberal' policies 'in an attempt to regulate people's values and beliefs' (Joppke 2012: 1).

Culturalizing the 'values of the Republic,' such as exacerbated by the departure from State neutrality vis-à-vis personal visions of the good, carries the twofold danger that public culture becomes homogenized and 'others' excluded. This is what Habermas (2004: 14) warns about: for him, the ambivalence between the ethical-cultural and legal-political sides of the language of common values paves the way toward

the predominance of a majority culture, which abuses its historically acquired influence and definitional power to decide according to its own standards what shall be considered the norms and values of the political culture which is expected to be equally shared by all.

Such an identity-based reading of 'living together' (le viure-ensemble) increases the probability that in order to be accepted into the Republic, individuals and groups who espouse different values - or values perceived to be different - will be forced to prove that they conform to a way of life which has 


\section{M. Hachimi Alaoui and J. Pélabay}

been declared to be 'ours' without any further justification being called on to confirm its validity. This would quite simply result in transforming the observance of rights and legal duties, which are mandatory for all, into a cultural conformity requirement.

It is highly probable that such an identity-based definition of political integration makes the measures designed to support it entirely counter-productive. By favoring the tendency to play the 'value system' of the majority group over 'value systems' attributed to minorities, it fails on two levels visà-vis its own stated ambitions: the reinforcement of 'republican values,' and reciprocal understanding within a diversified society. The coupling of national identity with democratic citizenship, which the substantialization of the 'values of the Republic' entails, weakens the universalist claim of democratic principles and basic rights by making them just one 'value system' amongst others and in competition with these others. Such weakness undermines the distinctive normative status that characterizes public norms and rights proper to a republican citizenship that steers away from competition with collective identities. Furthermore, such a coupling increases the risk of creating a fragmented society as it multiplies reasons for disagreement and distrust between 'us' and 'them.' The entire inclusive and pluralist ambition of a society then becomes compromised.

\section{Conclusion}

The possible dangers of homogenization and exclusion, as discussed above, are not specific to the French State's promotion of 'shared values.' These are two worrisome tendencies that concern the European Union (EU) as a whole. Facing the challenge of their 'democratic deficit' (Føllesdal \& Hix 2006), EU institutions, notably the European Commission (Dratwa 2014), have been engaged in the public promotion of a set of 'core values,' which have been declared to unite European citizens and nations, and to form the foundations of the EU. From the call for an 'extra touch of soul' by Jacques Delors $^{4}$ (1989) to the plea for the EU to be a 'community of values' (and not a mere interest-based group) by José Manuel Barroso ${ }^{5}$ (2007), such discourse expresses the desire to foster a sense of belonging to the EU, and thus its 'input' or 'subjective' legitimacy (Bellamy \& Castiglione 2008), through a shared belief in 'European values.' Of course, the declared 'values of the EU' mainly refer to freedom, democracy, the rule of law, tolerance, and mutual respect. In this way, they might be interpreted as a set of purely legal norms or universal ideals of justice; and the very fact that within the Lisbon Treaty, in particular, the articles that state the conditions of inclusion/exclusion to/ from the EU, the term 'values' has replaced the term 'principles' used in the treaties up to that time, might seem to be an irrelevant semantic detail. However, it should be observed that those who apply the language of common values in support of European integration stress that references to 'European values' gain their added value - compared to constitutional 
principles - from their strength in terms of cultural identification. And most importantly, such identity potential, encapsulated in the appeal to 'Europeanness,' is considered an asset in overcoming challenges to the legitimacy of the EU, thus recoupling ethical-cum-cultural and political integration. This is the point made by Barroso (2013) when he declared that if we are to build 'a new narrative for Europe,' 'we must never give up any of our values, our culture or our way of life, our European way of life.'

The promotion of a European thick community as the foundation of the EU is made explicit by the communitarian thinker Amitai Etzioni. In his view (Etzioni 2007: 24), European integration needs a 'normative-affective' community characterized by 'a core of shared values (i.e. a moral culture) and a web of bonds of affection,' and he adds: these are 'particularist values' (Etzioni 2007: 33), not universal ones, which embody some 'shared understandings of what is good,' not of what is right (Etzioni 2005: 132). Like their national(ist) counterparts, the European discourse and practice of common values tends to dismiss the thin and cold language of legal norms and universal principles of justice as a sound basis for integration. But it might well be that a politics of rights proves to be more effective and legitimate not only to overcome the combined dangers of homogenization and exclusion attached to the politics of common values but also to reach integration within culturally and ethically divided societies.

In this respect, a return to the field survey is instructive. During CAI civic training sessions, we observed that both trainers and migrants made a distinction between what is relative to the area of law and what pertains to culture and morals, thus giving concrete expression to the philosophical differentiations between 'political' and 'ethical' conceptions of integration. The part that focusses on 'Values, principles and symbols of the Republic,' and in particular gender equality and reciprocal relations between men and women, was frequently an occasion for the trainers to make the session interactive, allowing participants to contribute to the discussion. When one trainer asked if a woman should obey her husband, one woman explained by answering: 'Whether it's here in France or where we come from, it's the same thing; you can't have two captains on a boat! If you want it to work, there has to be one captain only!' The whole room laughed, and another participant added: 'If you're told you're the man, you're the man! For me, a woman must obey her husband.' As there was uproar in the room, the trainer took the floor again and she explained: 'The civil code is clear: within the household, authority is shared by the father and the mother. That's the law, that's the way it is.' The room calmed down and the trainer continued with her program. During a discussion about polygamy in a training session in Paris entitled 'Rights and duties of parents' one participant took the floor and began a long explanation of the reasons for polygamy in his country and he ended by concluding: 'But anyway, we know it's forbidden here, it's the law, that's the way it is.' These different examples reveal that a de 


\section{M. Hachimi Alaoui and J. Pélabay}

facto shift is occurring from cultural values, which public discourse places at the core of civic training, to legal norms. Both trainers and participants recognize that the law is what counts. These observations show the advantage of placing the question of common rules that must be respected on the objective level of the law, rather than on the level of moral and cultural values belonging to a warm and thick identity. By using the language of law, many trainers escape discussions which would place different values and competing value systems at odds with each other.

As analyzed by this piece of field research, and as convincingly argued by Justine Lacroix (2009) in relation to the political theory of European integration, there is good reason to give priority, in theory and in practice, to a rights-based - instead of a values-based - conception of integration. For nothing prevents the discourse and practice of common values, be they national or European, from transmuting into a homogenizing and exclusionary identity politics focused on the survival of an ethical-cum-cultural version of the 'us', at the expense of the search for a truly pluralistic type of integration.

\section{Notes}

1 On the distinction between 'thick' and 'thin' morality, see Walzer 1994 (xi, note 1) where he qualified as 'thick' a 'kind of argument' which is 'richly referential, culturally resonant, locked into a locally established symbolic system or network of meanings,' by contrast with a 'thin' argument which refers to 'universalist morality,' including procedural principles of justice.

2 In France, the wearing of the Islamic headscarf and niqab in public is debated under the terms 'veil' ('voile' or 'foulard') and 'full-face veil' ('voile intégral') respectively.

3 Language levels going from A1 to $\mathrm{C} 2$ correspond to the Common European Framework of Reference for Languages.

4 Jacques Delors was President of the European Commission from 1985 to 1994.

5 José Manuel Barroso was President of the European Commission from 2004 to 2014.

\section{References}

AFP (Agence France Presse) (2009). 'Besson relance spectaculairement le débat sur l'identité nationale,' 25 October.

Barroso, J. M. (2007). Speech for the 3rd European Ecumenical Assembly, Sibiu, 6 September. Available at: http://europa.eu/rapid/press-release_SPEECH-07-509_fr. htm?locale $=$ FR

Barroso, J. M. (2013). Speech 'A new narrative for Europe,' BOZAR/Brussels, 23 April. Available at: http://europa.eu/rapid/press-release_SPEECH-13-357_en.htm

Bellamy, R. \& Castiglione, D. (2008). 'Beyond community and rights: European citizenship and the virtues of participation,' in Mouritsen, P. \& Jørgensen, K. E. (eds), Constituting Communities: Political Solutions to Cultural Conflict. Basingstoke: Palgrave MacMillan, pp. 162-186.

Bouvet, L. (2015). L'insécurité culturelle. Paris: Fayard. 
Brubaker, R. (2001). 'The return of assimilation? Changing perspectives on immigration and its sequels in France, Germany and the United States,' Ethnic and Racial Studies 24(4), pp. 531-548.

Cameron, D. (2011). PM's Speech at Munich Security Conference, 5 February. Available at: www.gov.uk/government/speeches/pms-speech-at-munich-security-conference

Cournil, C. \& Depigny, Y. (2008). 'Contractualisation et externalisation de la politique migratoire: Analyse et critique de la loi Hortefeux,' Revue du Droit Public 4, pp. $1045-1079$.

Delors, J. (1989). Speech at the European Parliament, 17 January. Available at: www. cvce.eu/content/publication/2003/8/22/b9c06b95-db97-4774-a700-e8aea5172233/p ublishable_fr.pdf

Dhume-Sonzogni, F. (2016). Communautarisme. Enquête sur une chimère du nationalisme français. Paris: Demopolis.

Dratwa, J. (2014). 'How values come to matter at the European Commission,' Politique européenne 45, pp. 86-121.

Etzioni, A. (2005). 'Affective bonds and moral norms: A communitarian approach to the emerging global society,' International Politics and Society, 3, pp. 127-143.

Etzioni, A. (2007). 'The community deficit,' Journal of Common Market Studies 45(1), pp. 23-42.

Etzioni, A. (2011). 'Citizenship in a communitarian perspective,' Ethnicities 11(3), pp. $336-349$.

Fassin, E. (2010). 'Unusual suspects: la précarité nationale,' in Coroller, C., et al., Vous êtes Français? Prouvez-le! Paris: Denoël, pp. 155-168.

Fassin, D. \& Fassin, E. (2006). 'À l'ombre des émeutes,' in De la question sociale à la question raciale. Paris: La Découverte.

Faucher, F. \& Boussaguet, L. (2018). 'The politics of symbols: Reflections on the French government's framing of the 2015 terrorist attacks,' Parliamentary Affairs, 71(1), pp. 69-195.

Føllesdal, A. \& Hix, S. (2006). 'Why there is a democratic deficit in the EU: A response to Majone and Moravcsik,' Journal of Common Market Studies 44(9), pp. 533-562.

Goasguen, C. (2011). 'Information Report by MP Claude Goasguen on nationality law in France,' 29 June. Available at: www.assemblee-nationale.fr/13/rap-info/i3605.asp

Guaino, H. (2010). 'Tout concourt insidieusement à affaiblir notre modèle républicain,' interview by F. Fressoz \& A. Leparmentier, Le Monde, 11 December, p. 10.

Habermas, J. (1995). 'Reconciliation through the public use of reason: Remarks on John Rawls's political liberalism,' The Journal of Philosophy 92(3), pp. 109-131.

Habermas, J. (1998). The Inclusion of the Other. Studies in Political Theory. Cambridge, MA: MIT Press.

Habermas, J. (2004). 'Religious tolerance - The pacemaker for cultural rights,' Philosophy 79(307), pp. 5-18.

Hachimi Alaoui, M. (2012). 'L'intégration sous condition: valeurs non négociables et égalité des sexes,' Canadian Journal of Women and The Law/Revue femmes et droit 24 (1), pp. 114-134.

Hachimi Alaoui, M. (2014). 'Intégration et lien de citoyenneté. Le cas du Contrat d'accueil et d'intégration,' in Paugam, S. (ed.), L'intégration inégale. Force, fragilité et rupture des liens sociaux. Paris: Presses Universitaires de France, pp. 429-444.

Hachimi Alaoui, M. (2016). 'L'immigration familiale: une obligation d'intégration républicaine. Enquête sur le Contrat d'Accueil et d'Intégration,' Recherches familiales, 13, pp. 79-93. 


\section{M. Hachimi Alaoui and J. Pélabay}

Hajjat, A. (2012). Les frontières de l'identité nationale. L'injonction à l'assimilation en France métropolitaine et coloniale. Paris: La Découverte.

Haut Conseil à l'Intégration, Propositions d'amélioration du Contrat d'Accueil et d'Intégration, Avis à Monsieur le Premier ministre, September 2006.

Helly, D. (2009). 'La légitimité en panne? Immigration, sécurité, cohésion sociale, nativisme,' Cultures $\mathbb{E}$ Conflits, 74, pp. 11-62.

Holtug, N. \& Mason, A. (2010). 'Introduction: Immigration, diversity and social cohesion,' Ethnicities 10(4), pp. 407-414.

Honohan, I. (2016). 'Civic integration: the acceptable face of assimilation?' in Sager, A. (ed.), Ethics and Politics of Immigration: Core Issues and Emerging Trends. London, Rowman and Littlefield, pp. 145-158.

Immigration Act n²007-1631 (2007) On the Control of Immigration, Integration, and Asylum. 20 November.

Joppke, C. (2010). Citizenship and Immigration. Cambridge: Polity Press.

Joppke, C. (2012). The Role of the State in Cultural Integration: Trends, Challenges, and Ways Ahead. Migration Policy Institute. Available at: www.migrationpolicy.org/ research/TCM-state-role-in-cultural-integration

Klarsfeld, A. (2012). Public hearing in the presence of the media during the 11 January 2012 session, chaired by M. Jean-Luc Warsmann, Assemblée nationale, Commission des lois constitutionnelles, de la législation et de l'administration, Compte-rendu 26. Available at: www.assemblee-nationale.fr/13/pdf/cr-cloi/11-12/ c1112026.pdf

Kostakopoulou, D. (2010). 'Matters of control: Integration tests, naturalisation reform and probationary citizenship in the United Kingdom,' Journal of Ethnic and Migration Studies 36(5), pp. 829-846.

Kriegel, B. (2005). 'L'unité doit se construire,' interview by B. Thiolay, L'Express, 24 November 2005, 2838, p. 73.

Lochak, D. (2009). 'Devoir d'intégration et immigration,' Revue de droit sanitaire et social 1, pp. 18-30.

Lacroix, J. (2009). 'Does Europe need common values? Habermas vs. Habermas,' European Journal of Political Theory 8(2), pp. 141-156.

Macedo, S. (2000). Diversity and Distrust. Civic Education in a Multicultural Democracy. Cambridge: Harvard University Press.

Mariani, T. (2003). 'Report $n^{\circ} 949$ on the Draft Law ( $n^{\circ} 823$ ) on the Control of Immigration and Residence of Foreigners in France,' 18 June. Available at: www. assemblee-nationale.fr/12/rapports/r0949.asp

Ministry of Internal Affairs, Internal Security and Local Liberties (2004). Memo NOR/ INT/D/04/00006/C. 20 January.

Mouritsen, P. \& Jørgensen, K. E. (2008). Constituting Communities: Political Solutions to Cultural Conflict. Basingstoke: Palgrave Macmillan.

Pélabay, J. (2011a). 'L'Europe des "valeurs communes" et le recul du multiculturalisme: la diversité supplantée par l'unité?' Revue Philosophique de Louvain 109 (4), pp. 747-770.

Pélabay, J. (2011b). 'Former le “bon citoyen” libéral,' Raisons politiques 44(4), pp. 117-138.

Pélabay, J. (2014). 'Privatiser les valeurs publiques. La citoyenneté comme intime conviction?' in Muxel, A. (ed.), La vie privée des convictions. Politique, affectivité, intimité. Paris: Presses de Sciences Po, pp. 39-60. 
Pélabay, J. (2017a). 'Les valeurs de la République: Un credo de combat?' in Muxel, A. (ed.), Croire et faire croire. Usages politiques de la croyance. Paris: Presses de Sciences Po, pp. 119-136.

Pélabay, J. (2017b). 'La République des "valeurs": entre public et privé, quel lien citoyen?' in Perrineau, P. and Rouban, L. (eds), La démocratie de l'entre-soi. Paris: Presses de Sciences Po, pp. 119-132.

Tabet, M-C. (2002). 'Polygamie, le gouvernement va mettre de l'ordre,' Le Figaro, 21 November, 18129 , p. 5.

Tiberj, V. (2014). 'L'islam et les Français: cadrage des élites, dynamiques et crispations de l'opinion,' Migrations sociétés 6, pp. 165-180.

Walzer, M. (1994). Thick and Thin: Moral Argument at Home and Abroad. Notre Dame: University of Notre Dame.

Zappi, S. (2003). 'François Fillon juge "inconcevable" et "dangereuse" une politique de discrimination positive', Le Monde, 9 December, p. 11. 


\title{
9 Box-ticking exercise or real inclusion?
}

\author{
Challenges of including refugees' \\ perspectives in EU policy
}

Robert Larruina and Halleh Ghorashi

\section{Introduction}

The twentieth and twenty-first centuries have seen significant movements of individuals from their countries of birth due to natural disasters, economic inequality, war, and political conflicts. This era has been called 'the era of mobility' (Urry 2007) or 'the age of the refugee' (Said 2001:173). Since 2000, migrant reception and integration has been one of the most significant topics in contemporary political and public debates in Western society, especially in Europe and the United States. And once migrants and refugees have overcome all the legal and formal obstacles to settling in their host societies, their journey is far from over. As Priya Kissoon (2010: 4) states, 'Arriving to safety often entails a dramatic devaluation of refugees' human capital and social status: a flight from persecution to destitution.' Refugees face challenges of equal participation and inclusion in their new societies (Ghorashi 2015). These challenges are related to the (often subtle but sometimes blatant) exclusionary mechanisms ingrained in practices and categories of thought that limit equal participation and recognition of migrants' contributions. Including migrant voices in ways that make a difference is a fundamental part of the core values of democratic societies (Ghorashi 2010a). In line with this, Iris Young (2006) connects two principles of social justice to the very fundaments of democracy: the right to self-determination and the right to self-development. The first principle is related to individuals' opportunities for equal access to societal resources, and the second is connected to their freedom to pursue life in their own ways. However, to ensure these opportunities and freedoms do not bring harm to others, they have to remain within pertinent legal and moral frameworks (Ghorashi 2010a).

Since 2015, refugees' struggles to cross European borders have shown a different side of the era of mobility, one that accentuates the interface of mobility with inequality and shows the paradoxes in governing mobility and border. The reception and integration of migrants and refugees has therefore become a much-debated issue among academic researchers and policymakers (Feischmidt, Pries, \& Cantat 2019; Larruina, Boersma, \& Ponzoni 2019). Despite different policy approaches (from target group to mainstream, 
generic policies) (Jacobs \& Rea 2007; Scholten et al. 2017), most countries adopt a 'top-down' approach to integration (Korac, 2003) on the national level (Scholten 2018). Nonetheless, the top-down, state-centric approach is currently shifting towards a multi-level governance approach in which increasing prominence is given to local governance (Zapata-Barrero, Caponio, \& Scholten 2017).

Regardless of the approach taken, existing integration policies consider the experiences and needs of migrants and refugees. An example of multi-level governance that tries to consider the central role of migrants and refugees is the European Migrant Advisory Board (EMAB, also called the 'Board' in this chapter). This pilot is an initiative of the Partnership on Inclusion of Migrants and Refugees (from now on, 'the Partnership') and is financially supported by the Open Society Foundations (European Commission n.d.; Open Society Foundations 2019). The EMAB's aim is to include former migrants' and refugees' voices in European policymaking and thereby contribute to their advocacy activities (Larruina \& Berg 2018). Though the EMAB advises the Partnership, it is not part of that collective. Its ultimate goal is to propose and implement ways for better managing the integration of migrants and refugees, considering cities' needs and challenges in particular. The Partnership, on the other hand, includes cities and countries as well as European associations.

This chapter discusses our study of the EMAB's initial work, focusing on the possibilities and constraints the members encountered in their efforts to contribute and bring their perspectives and experiences to the Partnership. Despite the EMAB's name, eight of the nine initial members had refugee backgrounds, and its activities were strongly focused on refugee integration policies; therefore, we see this case as an example of refugee inclusion. Our study was guided by the following question: What are the challenges and opportunities of including refugees' perspectives in EU policy? By answering this question, we contribute to understanding of the complexities of including lesser-heard voices in policymaking.

After a theoretical discussion, we present methodological reflections and then elaborate on the EMAB's experiences. The final section discusses the implications of our data.

\section{Power, participation, and co-creation}

A major debate about the challenges and opportunities in the creation of spaces for inclusion, spaces that create chances for refugees' experiences and expert perspectives to tackle the blind spots of policy, is to what extent these spaces are real in their inclusionary promise and do not remain a mere symbolic practice. In the following, we present theoretical approaches of visible and invisible forms of power and discuss various concepts (such as deep democracy and co-creation) related to the conditions of inclusion. 


\section{Visible and invisible power}

How should scholars understand the challenges of including refugees' perspectives within the complex structures where EU policy is made? Inclusion always involves power relations; however, there are many approaches to power in the academic literature (Hardy \& Leiba-O'Sullivan 1998). Lukes's (1974) three-dimensional power is useful for exploring several ways that power is at play. The first dimension of power emphasizes decision-making on matters involving a visible conflict of interests (Lukes 1974: 15). Consequently, the most influential actors in society are those who win the majority of conflicts (Dahl in Lukes 1974: 12-13). The second dimension, which is based on Bachrach and Baratz's (1962) work, recognizes the way in which decisions are prevented from being taken on issues involving a clear conflict of interest (Wilson \& Thompson 2001). According to Bachrach and Baratz (1962), problems that do not arise on the political agenda can be just as important as those that do. The third dimension takes the process of nondecision-making further and is about hegemonic power, in which the status quo is not questioned but taken for granted. A framework that considers all three dimensions of power is relevant for understanding power struggles in the decision-making process. It allows the incorporation of tensions that emerge in the policymaking arena (first dimension), actions and omissions that give shape to the establishment of priorities (second dimension), and actions and omissions that form the perceptions, understandings, and preferences of the relevant actors (third dimension).

To these, we add a fourth dimension of power - discursive power. Hegemonic power (Lukes's third dimension) is seen as domination by certain groups, assuming that there are powerful and subordinated groups. A discursive approach to power argues that all individuals are normalized in their actions by the power of dominant discourses regardless of their hierarchical position (see also Ghorashi \& Sabelis 2013). In his book Discipline and Punish, Foucault (1975) elaborates the concept of normalization through his description of disciplinary power. Normalization, according to Foucault, involves the construction of idealized norms of conduct that gradually become taken for granted. In other words, individuals refer to a norm that could become an ideal they strive towards. In that sense, disciplinary power normalizes individuals so that they eventually speak, think, and act in similar ways (Lilja \& Vinthagen 2014). Disciplinary power can be seen as a system of knowledge that understands the individual as an 'object to be known in relation to others who can be known' (Lilja \& Vinthagen, 2014: 109). For Foucault, disciplinary power has not only inhibiting and restraining characteristics but also productive characteristics that make things happen. This idea is intrinsically related to the notions of biopower and governmentality. Bio-power has the capacity to gradually turn people into subjects and is exercised by state organizations and institutions (i.e. police, church, army) and the like. Therefore, normative power is a form of power present in everyday practices through which 
individuals are categorized and form their identities. To study power, then, we must study how 'subjects are gradually, progressively, really, and materially constituted through a multiplicity of organisms, forces, energies, materials, desires, thoughts, etc.' (Foucault 1994: 35).

We also added Gaventa's (2016) definition of participatory spaces to investigate the visible and invisible ways the four dimensions of power manifest themselves in the amount of space that is created to include less privileged perspectives (from no access to creating their own spaces). Gaventa elaborates on three types of participatory spaces for citizen initiatives: closed spaces, invited spaces, and created spaces. Closed spaces are where decisions are taken by policymakers without input from other stakeholders. This is the space where elected representatives or governments act without any broader consultation. Invited spaces constitute a shift from closed to open spaces. Here, stakeholders/actors are invited to participate. Finally, created spaces are shaped by stakeholders with less power or influence over a particular issue. The interplay between closed, invited, and created spaces brings challenges for citizen and minority group engagement with governmental organizations because merely participating in these spaces does not guarantee that marginalized groups will be allowed to have meaningful contributions. Thus, despite the proliferation of new opportunities for citizen and migrant engagement in different policy processes (Gaventa, 2016), their participation has not necessarily led to better refugee inclusion. However, those invited by 'dominant groups' could try to increase their power by demanding transparency and accountability and more democratic structures (Gaventa 2016).

\section{Quality of participation: from tokenism to co-creation}

To examine the quality of participation in various spaces, we used Arnstein's (1969) ladder of participation, which distinguishes three notions: tokenism, co-creation, and co-option. Arnstein's ladder consists of eight different levels, divided into three groups, and the power citizens have increases as one moves up the ladder. The bottom steps of the ladder, manipulation, and therapy, make up the non-participation group. The middle steps - informing, consultation, and placation - represent a higher group of participation: tokenism. Here, participants get the opportunity to make their voices heard, but their involvement often has no impact (Arnstein 1969).

Zimmer (1988) and Laws (1975) elaborate how the term 'token' refers to a mere symbolic presence without genuine impact. Simmel (1950) and Hughes (1945) speak of 'stranger' and 'outsider,' respectively. They refer to an individual who matches the relevant profile to enter an organization or group but does not have 'auxiliary characteristics' that are common to the individuals in those groups (e.g. race, sex, ethnicity). Those seen as strangers or outsiders are never permitted by 'insiders' to be full members of the group, 


\section{2}

R. Larruina and H. Ghorashi

and they risk being rejected if they move too far from the special 'niche' assigned to them (Hughes, 1945; Simmel, 1950). The term 'token' has also been used to refer to individuals who are admitted to a group because of their difference from others in the group. In many situations, the token person is used as proof that the group does not discriminate against such people (Zimmer 1988).

Kanter (1977: 210-12) incorporated the concept of token in her theory of organizational behavior, reporting three interactional perceptual tendencies that lead to negative token dynamics: visibility, contrast, and assimilation. Visibility happens when the token gets attention and becomes more present than the dominant group alone. This leads to what Kanter calls a 'larger awareness share' because tokens, and the group they belong to, make the dominant group they have joined more visible. Contrast or polarization occurs when individuals from the dominant group exaggerate their differences with tokens (Kanter 1977). This mainly happens when the dominant group is hesitant about how to deal with the token, and it may eventually lead to the token's isolation. Lastly, assimilation is the process by which tokens are encapsulated into stereotypes or common generalizations about the token's group. 'So tokens are, ironically, both highly visible as people who are different and yet not permitted the individuality of their unique, non-stereotypical characteristics' (Kanter 1977: 211-12).

Token-related behaviors may lead to co-option, assimilation, taking, or winning over into a larger or established group (Coy 2013). Widely used in social and policy studies, co-option refers to the diverting in into a role different from the original one. It refers to the actions by which cooperation and collaboration with official organizations and inclusion (in the polity) turn into situations where the individuals or organizations invited to participate lose their original purpose and innovative essence. In this we see a clear example of the willingness to include, which ultimately turns into exclusion through co-option, or assimilation, of potentially different perspectives. This is partly due to the paradox of survival. For less privileged groups, it is essential to show that their perspective is valuable because it is different, but they often need to be fully incorporated into the system to survive. It is therefore important that scholars address the issues of power, space, and quality of participation together (see Table 9.1) to understand the possibilities and constraints disadvantaged groups face when invited to participate in mainstream spaces.

The final group in Arnstein's (1969) ladder of participation is 'citizen control,' which comprises the three top steps of the ladder. This group represents the highest degree of citizen participation in and influence on decision-making. There is indeed a noticeable redistribution of power between citizens and those in power. With this model, Arnstein calls for a redistribution of power that enables the 'have-not citizens,' presently excluded from the political and economic processes, to be deliberately included in the future (Arnstein 1969: 216). 
Table 9.1 Correlation between participation, tokenism, co-creation, and participatory spaces

\begin{tabular}{|c|c|c|c|c|}
\hline \multirow{2}{*}{$\frac{\text { Arnstein }}{\text { Participation }}$} & & \multicolumn{2}{|l|}{ Kanter } & \multirow{2}{*}{$\begin{array}{l}\text { Gaventa } \\
\begin{array}{l}\text { Participatory } \\
\text { spaces }\end{array}\end{array}$} \\
\hline & & Tokenism & Co-creation & \\
\hline \multirow{3}{*}{$\begin{array}{l}\text { Citizen } \\
\text { control }\end{array}$} & Citizen control & & Citizen as & Created space \\
\hline & Delegation & & initiator & \\
\hline & Partnership & $\begin{array}{c}\text { Assimilation/ } \\
\text { Co-option }\end{array}$ & $\begin{array}{l}\text { Citizen as } \\
\text { co-designer }\end{array}$ & Invited space \\
\hline \multirow[t]{3}{*}{ Tokenism } & Placation & Contrast & & \\
\hline & Consultation & Visibility & Citizen as & Closed space \\
\hline & Informing & & co-imple- & \\
\hline \multirow{2}{*}{$\begin{array}{l}\text { Non- } \\
\text { participation }\end{array}$} & Therapy & & & \\
\hline & Manipulation & & & \\
\hline
\end{tabular}

Source: Arnstein (1969), Kanter (1977), Gaventa (2016)

\section{Co-creation, deep democracy, and reflective capacity}

Co-option as a concept is especially relevant for studying policy advice and advocacy, since it is a possible outcome of well-intentioned inclusion practices. Concepts such as co-creation and co-production (which relate to Arnstein's citizen control and Gaventa's invited spaces) are alternatives to cooption that respect the agency of marginalized groups and their capacity to adjust and to compromise. Co-creation involves processes of mutual adjustment among different stakeholders and the inclusion of different types of knowledge and perspectives in the policymaking process, but most importantly, it is about the active involvement of end-users (e.g., customers, clients, citizens) in various stages of the creation process (Voorberg, Bekkers, $\&$ Tummers 2013). In the domain of collaborative governance and community involvement, Voorberg, Bekkers and Tummers (2013) distinguish three types of co-creation that differ in their degree of citizen involvement. The first type involves the citizen as co-implementer of public services (citizens responsible for some execution tasks). The second type describes the citizen as co-designer. Here, the initiative remains within the public organization, and citizens decide how the service delivery is designed. The third type characterizes the citizen as an initiator and the government as an actor that follows the citizen's recommendations. These variations in public participation and the space for citizen's voices and perspectives are based on discussions of democracy and inclusion.

In her seminal work, Inclusion and Democracy, Iris Young (2006) discusses the idea of democratic practices as a means to promote justice, and she calls for a widening and deepening of the idea of the democracy. 


\section{R. Larruina and H. Ghorashi}

Deep democracy goes further than the traditional notion of democracy, which is characterized by the rule of law, promotion of liberties, and fair elections of governments, and suggests some steps to enact this democratic deepening through inclusion. Young states that 'the normative legitimacy of a democratic decision depends on the degree to which those affected by it have been included in the decision-making processes and have had the opportunity to influence the outcomes' (Young 2006: 5). This means the chances that democratic decision-making practices will stimulate justice and the inclusion of collective problem-solving are improved by the presence of diverse groups, opinions, and perspectives (Young 2006: 6-7). Inclusive democratic practices stimulate fairer outcomes because they allow individuals the opportunity to influence others about the virtues of their claims and to negotiate their interests, which might change during the negotiating process.

Critical diversity scholars argue that the development of inclusive space requires reflective capacity to counteract normalized forms of exclusion (e.g. Rast \& Ghorashi 2018; Ghorashi \& Ponzoni 2014; Zanoni \& Janssens 2007). Space for reflectivity can be created in personal encounters and at group, organizational, and societal levels (Ghorashi \& Sabelis 2013; Ghorashi 2014; Ghorashi 2017). In these spaces, participants are willing to question and disrupt historically rooted images about the self and the other that are informed by the dominant discourses, and they are willing to engage meaningfully with others whose lifeworlds - that is, their experiences, activities, and social contacts - are quite different than their own. Only then can invited spaces become inclusionary and stimulate possibilities for creating spaces, in which both normative and hierarchical power are challenged and new forms of connectedness based on equality between all participants are stimulated.

\section{Research approach and methods}

Access to the Board and the Partnership was possible thanks to the municipality of Amsterdam, the Partnership coordinator, which commissioned a research report (Larruina \& Berg 2018) about constraining and enabling elements for the Board's existence. This research was conducted in the context of the Refugee Academy, an expertise laboratory at the Vrije Universiteit Amsterdam. The data collected for the report was complemented with other documents produced after our fieldwork ended. For this qualitative case study (Baxter \& Jack 2008; Yanow \& Schwartz-Shea 2015), we conducted semi-structured interviews, observations, and document analysis. The interviews, conducted between May and June 2018, allowed us to get participants' (Board and Partnership members) insider views on their experiences with the Board's activities. The interviews were mostly conducted through Skype and were held in English or Dutch. Most respondents were invited through an introductory email with a tentative topic list, which was 
developed in cooperation with the Partnership's coordinator. We accessed other respondents through a secondary source: interviews conducted in January 2018 by a European Studies student from the University of Amsterdam, who researched the Board's potential influence on the European arena and its policymaking process. Use of these transcripts, approved by the student and the Partnership coordinator, was done to avoid overlapping respondents. We conducted nine interviews, four with Board members, and five with members of Partnership organizations. An additional two Partnership members were included through the secondary source. Respondents requested absolute anonymity; therefore, all references to age, gender, ethnic or religious background, and place of birth, residence, and work have been omitted or altered.

Observations were made during Board and Partnership activities, including two Board meetings (in Brussels and Amsterdam) and the Partnership's annual meeting (in Brussels), which included the Board. These observations (approximately 80 hours) provided data for understanding the 'totality' of the context where the Board operated (Moeran 2009). We also analyzed public and internal documents (Bryman 2012) produced by different parties involved in establishing the Board. While the public documents were available on the Partnership's website, the internal documents were distributed on a research platform managed by the municipality of Amsterdam (Open Research Amsterdam), which was only accessible to the researchers and the Partnership.

By triangulating the data from the interviews, observations, and document analysis, we were able to better understand and interpret the research situation. Our aim was to identify recurring topics and develop an overview of the different views, perceptions, and opinions of the Board and the Partnership. To systematize and analyze the data gathered, we used the grounded theory approach (Gioia, Corley \& Hamilton 2013). The following empirical findings are based on selected quotes from the interviews, observations, and documents that show common patterns and topics pertinent to our research question.

\section{Empirical findings}

This section presents the EMAB's challenges and opportunities 'to better manage the involvement of immigrants and refugees in policy-making processes' (European Commission 2019). We show how tokenization - and cooption-related mechanisms - have made it difficult for the Board to provide genuine policy advice despite the potential opportunities that the Board and the Partnership have.

\section{Logistical-organizational challenges}

The first phase was marked by delays in the Board's formation and the beginning of its activities. During the first week, the members were asked to 
get to know each other, to be trained by different NGOs and instructors, and to be introduced to the rest of the Partnership during different official activities. However, some activities were rescheduled or postponed.

During our first field observation and from interviews and some unplanned conversations, we observed elements concerning sustainability (funding) and bureaucratization. The need to secure funding to guarantee the Board's continuation after the initial funding by Open Society Foundations was a significant concern for the Board's initial work and its long-term vision.

The challenge is, what happens if they don't get the funding? What happens if they are not secured? How can they be? I think that we have to think within the Partnership, to find a way to really make this mechanism self-sustainable. If it's not through EU funding, we have to find another way. [...] Because people now are very enthusiastic, they want to do a lot, and this enthusiasm is good, but it can be really dampened, very easily. Whenever they get stuck in the bureaucracy of the European machine.

(Partnership 8)

This organizational respondent is aware of the crucial importance of funding to guarantee the Board's existence, something echoed by Board members as well. It indicates not only a concern for practical matters but also an engagement with the new group being formed: they were concerned about the immediate implications as well as the initiative's continuity after the current Board members are gone. Though we could not learn about the financial arrangements for the Board, we know that Open Society Foundations provided funding for only the first phase of the Board. Similarly, the Board and the Partnership showed concern about the excessive administrative procedures, in which policy advice is contextualized, and both were hesitant about the potentially excessive formalization of the Board's work. This fear had already materialized during the Board's first week, when excessive demands had a negative impact on the Partnership's planned introductory activities. Concerns about funding and being part of the administrative structures were clearly relevant for establishing the Board, but also for creating the right environment for building cooperative structures and for the Board's capacity to become a self-led group. However, after the researchers gave feedback to the Partnership coordinator, these concerns were clarified and resolved.

\section{Opportunities for co-operation}

Narratives provided by both Board and Partnership members make it clear that both sides are determined to take actions and work together towards their common objectives. One respondent from a Partnership organization explains that they support having refugees work with them, instead of designing policies for refugees. 
I am always in favor of sitting around the table with the people that we are talking about, and to not just make all kinds of beautiful, heavenlylooking texts behind a computer that nobody reads anyway. It is really about being with the people for who you are designing papers, to sit around the table with them and hear from them, 'Does it make sense?' or to ask them, 'What do you want?'

(Partnership 7)

Similarly, a Board member elaborates on the possibilities that the collaboration with the Partnership presents. They discuss how earlier approaches to making policies for rather than with refugees had failed, and therefore collaboration between policymakers and the targets of those policies is imperative to make substantial contributions.

I mean, they [the Partnership] invited us because they want us. And we want them too. [...] I want some powerful people to be in the same boat with me, you know. And at the same time, to bring a better Europe. If they want to work on more European policies towards integration, they want that because we are the best ones who can tell them what is really the problem. I mean, now the European politicians are aware that without us, they cannot fix the problems. [...] So, it's an opportunity for both sides.

(EMAB 4)

The following respondent goes further by highlighting that the main objective is to collaborate within the Board but also with the Partnership.

I think the main objective is that we are a group of migrants and refugees that work about [sic] different lines or different topics about migrants and refugees. [...] The idea is to work together, to defend very clear ideas in general for migrants and refugees obviously.

(EMAB 1)

All respondents emphasize the importance of having spaces for dialogue and of hearing from the policy-affected group directly. However, it is unclear whether the timeframes provided by the Partnership, and by EU institutions at large, match the Board's ability to deliver what is asked from them.

A respondent from the Partnership goes further in the opportunities for cooperation, explaining how the Board also advises civil society organizations that already have a role in policy advice within the European commission but lack the first-hand recommendations.

It might be an option to have some of those people of the Board work with the cities that are within XXXX working on migrants and refugees. That would be very interesting. But at the moment, we don't have that. [...] 
The Board hasn't worked directly with XXXX, but the Board could do that, and would be highly appreciated.

(Partnership 6)

Here, we see the Board's potential, not only in advising official EU organizations, but also in guiding civil society organizations already interacting with EU bodies. This brings another dimension for possibilities of cooperation and mutual learning between the Board and the network of organizations around it.

Besides acknowledging the Board's need and willingness to work with other stakeholders, our research reveals that the Board and the Partnership agree about their challenges: the negative discourse about refugees and the risk of being tokenized. A respondent from a Partnership organization, a person with extensive experience in policy advice on migration and integration, details what they understand are the main concerns that refugees face:

[Having previously enumerated negative discourse against migrants]. So that's really some stigmatization, I don't know if the term is correct, but you know what I mean, no? [...] So, diversity, pluralism, that's another big challenge, how to make sure that diversity is reflected. Diversity cannot just be non-discrimination, but it should be something more. Proactive inclusion [...]. What I see as pluralism is that all different voices are reflected in society.

(Partnership 7)

This respondent refers to the normalized ideas and perceptions currently surrounding refugees in Europe and how these are intertwined with what diversity and inclusion are. He refers to proactive inclusion as being a form of presence that considers all views and experiences. This is reinforced by a secondary source and by a Board member, both of whom indicate that the Board should also contribute to challenging the prevailing discourse on refugees and migrants.

Something else the Board can do to help is to create a positive narrative. Right now, migration is connected to negative thinking, waves, huge numbers, while in reality, it's not that big. And we need migration because of the greying [aging] population. We could use success stories, role models, etc.

(Partnership 9).

My expectation? A lot. But the thing is that we can't do much, but I really want the Board to act as a true representative of migrants and refugees, and to show the talent and the positive side of refugees. And I really want [sic] we could do something to change the narratives around migration. I really want - we need to change it 
Consequently, this extends the Board's aim beyond policy advice and towards an active contribution to changing negative perceptions and challenging normalized views and ideas. The strategies suggested by these respondents are intended to construct a positive narrative, yet they put the Board at risk of putting too much emphasis on appearances and media presence. This approach could result in the Board's developing a symbolic presence (peril of tokenism) rather than investing in a more significant contribution. However, the importance of creating counter-narratives is also stressed by other Partner organizations, as one Board member clearly describes.

I am so happy, and I would like if [sic] we could bring even a little change. It will be a [sic] really great achievement. Because it is not easy when you are talking with policymakers in Europe, and they [are] mostly forced by political will and so on. If you change something, it is really great.

(EMAB 2)

This Board member focuses on what can be done between symbolic presence versus significant contribution; they speak about the gratification of small actions within the complexity of policymaking at the EU level. This fragment also shows that the respondent is aware of how daunting the challenges and intricacies of the mechanism around his contributions are, yet he remains determined to bring a different perspective.

\section{The challenges of co-operation: ticking the box and being taken seriously}

The main aim of our research was to investigate whether the EMAB members' perspectives have been truly included or solely displayed publicly as a showcase. Interviews with some of the Partner organizations reveal doubts about the Board's influence on policy and concern that those voices are not being taken seriously. A respondent from a Partnership organization even compares the Board with a box-ticking exercise, an activity performed to serve a practicality rather than to accomplish something. 'The Board is now only being used as a box-ticking exercise for the Partnership' (Partnership 11).

In line with this, when asked how the Board's presence and advice could be treated with importance and with the attention and respect it deserves, a Board member responds:

We will keep following them [the organizations they advise]. [...] Because if we give the recommendations regarding to do something, and we don't see them responding, I mean, we will need to put more pressure [sic]. And this is going to be important with the relation we will make on a political level. [...] Having some politicians supporting us will be something important because sometimes we need to be 
invited you know. We cannot just open the door and say we want to sit on [sic] the table with you.

A respondent from the Partnership elaborates further, discussing the Board's promotion and media presence, but concludes that the final answer regarding advice by the Board still remains in the political will of the EU commission.

It depends really on the commission that decides as a whole. So, to take this Board inside the already complex EU decision-making process. [...] I think it's quite difficult. I support the fact the DG HOME can use this body, but it really depends on the willingness to do so. Because otherwise, if they only do that because they want to show that they are working with the target group, we're not going anywhere.

(Partnership 7)

The following respondent expresses similar sentiments while describing their reservations about the Board's success in a more graphic way.

So, I am a bit sceptical about it [EMAB]. [...] It depends of course on how ambitious the proposals are, the more ambitious a proposal is, the more it is likely to be watered down or perish. Mmm, so I might be prepared for that, but they [the Board members] know that too. They know how such a bureaucratic order as the EU works.

(Partnership 5)

Apparently, this perception of the Board being a symbolic effort to do a particular thing also prevailed in some of the cities where the Board members now live. Some cities have already suggested one advisory task: namely, determining how to ensure that people with refugee or migrant backgrounds are not being tokenized when asked to participate in the decision-making process. Therefore, this will be one of the Board's focus points (communication with Partnership, May 2018), and it remains a concern for Board and Partnership members alike. It also has implications for the Board's work and the application of their advice.

\section{Challenges in understanding representativeness: the inclusion of different perspectives}

Respondents from the Board shared their doubts about how genuine the representativeness of the Board could be considering the context, in which they operate. In this context, the notion of representativeness has two connotations: 1) speaking on behalf of a group or 2) being a sample or an example from that group. 
I think we are, as a Board, well represented, but we need to prove that for others too, who are not in the Board. That this Board is representing well. I don't want to say representing, because it is again about who is in the right place to represent us, but let's say, be a voice for many voices of immigrants in Europe.

(EMAB 4)

But the thing is that we can't do much, but I really want the Board to act as a true representative of migrants and refugees and to show the talent and the positive side of refugees. And I really want [sic] we could do something to change the narratives around migration.

(EMAB 2)

The second respondent links representativeness with the capacity - as well as the inability - to challenge dominant discourses. While the emphasis on representation shows understanding and commitment to the Board's role, it is not clear what the second respondent means by 'true' representativeness. Similar sentiments were expressed by other Board members, who expanded on the capacity to represent as being the ability to speak on behalf of a group.

Another respondent discussed how he does not like to define himself as a refugee, but he does not have another option within the context he operates. This Board member also feels he is a representative in the sense that he speaks on behalf of the diversity of migrants, rather than being a sample of the refugee population.

Okay, I don't like to describe myself as a refugee, but I have to. I feel like I have to because I am working for refugees, and I'm like, kind of, you know, representing them, or I voice, I'm a voice for refugees. And that's why I have to say that I'm a refugee. [...] I thought that I used to understand them, but it is totally different. No one can understand, you know, others unless you're in the same situation.

(EMAB 3)

This respondent clearly states that they do not like to frame themselves as a refugee, but they are directly and indirectly forced to do so in order to have a valid space to speak on behalf of other refugees. The documents and interviews reveal that the Board and the Partnership are searching for representatives. However, the question is how the notion of representation relates to the inclusion of perspectives from groups who are targets of policy. Are refugees' perspectives, which are influenced by their lived experiences and their varying networks, enough to make the present policies more inclusive? 


\section{Actions and absence of reflexivity}

In December 2018, at the time of our last observation, during the annual Partnership conference in Brussels, the Board presented the initial findings of a report based on an online survey (for the final report, see EMAB 2019). During the conference, the Board and its work were mentioned several times by the EU commissioner and other authorities. This produced immediate reactions on Twitter and other social media channels. Following the morning presentations from members of the Partnership, the Board presented its work in one of the many afternoon workshops. Civil society organizations and junior members of the Partnership were the main attendees. No commissioners or recognizable decision makers attended the workshop.

While the effect of the Board's report within EU institutions is outside the timeframe of this article, its introduction section shows that after half a year of EMAB's work, emphasis on representation (as being a sample of) is still present.

Since its establishment in March 2018, the EMAB has sought to represent and defend the interests of migrants and refugees in Europe.

(EMAB 2019: 3)

The consultation demonstrates that a vast reservoir of expertise exists among migrant and refugee representatives. Currently, experts with migrant and minority backgrounds are severely underrepresented in EU institutions and decision-making.

(EMAB 2019: 8)

The report does not mention concerns about tokenism and the need to be taken seriously nor does it indicate training or strategies to deal with these issues. The introduction elaborates on the Board's strengths, yet it fails to go beyond topics already widely discussed at research and policy levels.

The Board aims to amplify the perspectives of refugees and migrants in policy debate and contributes to improving integration policy by providing recommendations from local and grassroots organizations to policymakers on all relevant levels. [...] The consultation focused on eight areas: integration, access to the labor market, housing, higher education, participation, the situation of unaccompanied minors, microcredit, and the EU Action Plan on Return. Board members chose these topics as key issues based on the members' first-hand experience.

(EMAB 2019: 3)

This statement explains that the topics in the report were chosen based on the direct experiences of the Board members. However, it does not mention the danger of having a mere symbolic presence of migrant organizations at 
local and EU levels. While there is an appeal for 'structured participation' (p. 8), the report's conclusions do not add anything new to this matter.

From the EMAB's experience, governments and organizations need to regard participation as a right rather than a gift. To be meaningful, these efforts must include resources for participation, including for self-led refugee and migrant groups, so that newcomers can contribute to effective and sustainable policymaking.

(EMAB 2019: 8)

This report is important because it is the first of its kind at the European Commission level. However, it risks making the Board visible yet unable to trigger mechanisms that unsettle normalizing practices. The production of this document therefore presents a paradox: it delivers something that could potentially be meaningful for the group the EMAB advocates for, but at the same time, it gives a relatively limited amount of time to achieving one of its objectives (and mandate from the Partnership). Although strategies to bring about changes in the prevailing negative discourse on migration and refugees were present in all of our data, they are not present in the report. The mere production and promotion of this document does not mean that the Board will be able to make meaningful contributions to the policy issues the report addresses, since they face many other challenges.

\section{Discussion and conclusion}

By studying the challenges and opportunities of the European Migrant Advisory Board, this chapter explored the conditions needed to create meaningful inclusion in policy-making advice. Though the EMAB initially aimed at deconstructing the negative discourses about migrants and refugees and at making its own political integration genuine by avoiding becoming a token, it did not have specific strategies for implementing either of these points. It did achieve a large social media presence, but that also put it at risk of becoming a token. Another achievement was the publishing of a report (EMAB 2019); however, this publication did not bring anything new to the debate on the inclusion of refugees and migrants. Nevertheless, the EMAB's presence paves the way for possible changes in policy advice on refugees at the European Commission level, something that had been previously absent.

We found that the Board is at risk of falling into 'the danger of a single story,' referring to the idea that accounts of success can never be a good alternative to the negative discourse on migrants since both are essentializing and homogenizing (Ghorashi 2016). Board members are caught between providing success stories and carrying the burden of representation, which prevents them from being considered important enough for who they are, for having perspectives and narratives that come from their specific lifeworlds 
and their different networks, both of which are quite different than those of policymakers from the dominant group. This is in line with the slogan used in the Refugee Declaration for Effective and Sustainable Refugee Policy 'Nothing About Us Without Us!' which refers to the idea that no policy about refugees should be conceived without their full participation.

In the Netherlands, past attempts to focus on representative bodies of migrants have failed because they assumed group homogeneity, which encouraged representative bodies. This led to competition between these bodies in their claims of speaking on behalf of 'their community,' but they also highlighted the impossibility of actually representing the whole community (Schrover 2010). We learn from Dutch history that all attempts to put refugees' perspectives into a homogenous category of representation will fail, not only because of the heterogeneous reality of the group, but also because of the impossibility to represent such a group. This approach causes refugee participants to doubt their role while it minimizes their potential contributions based on their lived experiences and perspectives. These effects are mainly due to refugees' positioning in a different network or different phase of life compared to people in decision-making positions. When marginalized groups are invited to a space and then co-opted by the dominant party, the quality of their participation (their specific experiences, perspectives, and networks) is ignored. However, safeguarding the quality and value of their participation can break the mindset in policies normalized by the dominant discourse, which is often disconnected from the lived experiences of the target groups for which such policies are made.

This coincides with Ghorashi (2010b: 89), who emphasizes that 'the success of any societal participation depends on institutional trust and acceptance of participants' qualities and inclusion of their perspectives.' This means that for democratic practices to be inclusive in practice, spaces, conditions, and practices are needed that disturb normalized exclusionary structures. Inclusion in terms of co-creation or co-production of knowledge cannot be achieved solely by creating an inviting space (as a sign of decisionmakers' good will) and intending to be inclusive and to adapt a bottom-up approach. The space needs to include conditions that enable reflexivity towards invisible workings of power and that practice delayed (with patience) engagement with individuals from groups that are not used to being in a negotiating position. It is these kinds of inclusive spaces that allow counter-narratives to reveal themselves; these spaces enable a connectedness between the lifeworld of marginalized groups and the system world of the policymakers who want to include them. Such spaces enable the imaginations of people in power (Lukes 1974) to envision what is means to become a refugee, disconnected from the past, not fully connected to the present and uncertain about the future. This imaginary connectedness among different participants and stakeholders in an inclusionary space is the first step towards reflection on exclusionary structures and joint attempts to change those structures. 
In our case study, the Board members are defined by their migration experience, their networks that they bring to the policymaking field, and their professional and educational knowledge. Yet these qualities are caught up in token-related mechanisms. Not acknowledging the tensions, the Board members face leaves no space to take their perspectives seriously, because they are always considered to be either not successful enough or not representative enough. What is left is to use them as a showcase of inclusion, a token (Kanter 1977), and to make them fit in the system (leave their difference to become the same) through co-option (Coy 2013).

We believe that while the EMAB provides a much-needed space at the European Commission level, something that is relevant in its own right, this, and other less visible initiatives (at meso and micro levels) need to go a step further to overcome being a mere presence and become entities that contribute meaningfully. Co-creation practices, where different stakeholders encounter and develop their reflexive capacity, generate ways to deconstruct exclusionary and inclusionary processes. The refugee experience does not have to be a journey 'from persecution to destitution', as Kissoon (2010) described it; providing opportunities for refugees to make genuine contributions to policymaking opens possibilities for them to take the lead in their journeys to inclusion. Self-led routes to inclusion are a fundamental necessity for democratic societies: through such routes, refugees have more opportunities for equal access to societal resources (i.e., self-determination) and more freedom to pursue their lives in their own ways (i.e. self-development) (Ghorashi 2010a; Young 2006) while also directly and meaningfully interacting with other relevant stakeholders in their new homes.

\section{Acknowledgements}

We would like to thank all the respondents who took part in this research: while you all remain anonymous; we treasure your unique experiences and perspectives and your willingness to share them with us. We are also very grateful to Rinske Berg (MSc) for helping with the data collection during our initial fieldwork and to Tine Postma (MSc), who kindly provided transcripts of the interviews we used as secondary sources. We also thank Younes Younes (MSc) and Elena Ponzoni (Dr) for their contributions at different stages of the study. An early version of this chapter was presented at the annual conference of the Canadian Association for Refugee and Forced Migration Studies (CARFMS) at York University (Toronto). The comments and suggestions from those participants helped to improve this work. The views expressed in this article are the authors' own.

\section{Note}

1 Respondents requested absolute anonymity; therefore, all references to place of residence or work have been omitted from this list. 


\section{References}

Arnstein, S. (1969). 'A ladder of citizen participation,' Journal of the American Institute of Planners 35(4), pp. 216-224.

Bachrach, P. \& Baratz, M. S. (1962). 'Two faces of power,' The American Political Science Review 56(4), pp. 947-952. Available at: www.jstor.org/stable/1952796

Baxter, P. \& Jack, S. (2008). 'Qualitative case study methodology: Study design and implementation for novice researchers,' The Qualitative Report 13(4), pp. 544-559. Available at: www.nova.edu/ssss/QR/QR13-4/baxter.pdf

Bryman, A. (2012). Social Research Methods. Oxford: Oxford University Press.

Coy, P. G. (2013). The Wiley-Blackwell Encyclopaedia of Social and Political Movements. Oxford: Blackwell Publishing Ltd.

European Commission (2019). European Migrant Advisory Board (EMAB). Available at: https://ec.europa.eu/futurium/en/inclusion-migrants-and-refugees/european-m igrant-advisory-board-emab

European Commission (n.d.). Inclusion of Migrants and Refugees: Joint Migrants and Refugees. Available at: https://ec.europa.eu/futurium/en/node/1730

EMAB 1 Interviewed by Rinske Berg, May $82018 .{ }^{1}$

EMAB 2 Interviewed by Rinske Berg, May 82018.

EMAB 3 Interviewed by Rinske Berg, May 162018.

EMAB 4 Interviewed by Rinske Berg, May 182018.

EMAB (2019). Ask the People: A Consultation of Migrants and Refugees. Available at: https://ec.europa.eu/futurium/en/system/files/ged/ask_the_people_european_migra nt_advisory_board_report_final.pdf

Feischmidt, M., Pries, L. \& Cantat, C. (2019). Refugee Protection and Civil Society in Europe. Cham: Palgrave Macmillan.

Foucault, M. (1975). Discipline and Punish: The Birth of the Prison. New York: Vintage Books.

Foucault, M. (1994). 'Two lectures,' in Kelly, M. (ed.), Critique and Power: Recasting the Foucault/Habermas Debate. Cambridge, MA: MIT Press, pp. 17-46.

Gaventa, J. (2016). 'Finding the spaces for change: A power analysis,' IDS Bulletin 37 (6), pp. 23-33.

Ghorashi, H. (2010a). 'The right to be different: The position of Muslim migrants in the Netherlands', in Banakar, R. (ed.) Rights in Context: Law and Justice in Late Modern Society. Surrey: Ashgate, pp. 163-177.

Ghorashi, H. (2010b). 'From absolute invisibility to extreme visibility: Emancipation trajectory of migrant women in the Netherlands,' Feminist Review 94(1), pp. 75-92.

Ghorashi, H. (2014). 'Routed connections in late modern times,' in Vieten, U. M. (ed.), Revisiting I. M. Young on Normalisation, Inclusion, and Democracy. Houndmills: Palgrave Pivot, pp. 49-67.

Ghorashi, H. (2015). Refugees: A different Mindset for Europe. Available at: www.civil societyhowto.org/refugees-different-mindset-europe/

Ghorashi, H. (2016). Het gevaar van het enkelvoudig verhaal. 10 March. Available at: www.kis.nl/blog/het-gevaar-van-het-enkelvoudig-verhaal

Ghorashi, H. (2017). 'Negotiating belonging beyond rootedness: Unsettling the sedentary bias in the Dutch culturalist discourse,' Ethnic and Racial Studies 40(14), pp. 2426-2443.

Ghorashi, H. \& Ponzoni, E. (2014). 'Reviving agency: Taking time and making space for rethinking diversity and inclusion,' European Journal of Social Work 17(2), pp. $161-174$. 
Ghorashi, H. \& Sabelis, I. (2013). 'Juggling difference and sameness: Rethinking strategies for diversity in organizations,' Scandinavian Journal of Management 29(1), pp. $78-86$.

Gioia, D. A., Corley, K. G. \& Hamilton, A. L. (2013). 'Seeking qualitative rigor in inductive research: Notes on the Gioia methodology,' Organizational Research Methods 16(1), pp. 15-31.

Hardy, C. \& Leiba-O'Sullivan, S. (1998). 'The power behind empowerment: Implications for research and practice,' Human Relations 51(4), pp. 451-483.

Hughes, E. (1945). 'Dilemmas and contradictions of status,' American Journal of Sociology 50, pp. 353-359.

Jacobs, D. \& Rea, A. (2007). 'The end of national models? Integration courses and citizenship trajectories in Europe,' International Journal on Multicultural Societies 9 (2), pp. 264-283.

Kanter, R. M. (1977). Men and Women of the Corporation. New York: Basic Books.

Kissoon, P. (2010). 'From persecution to destitution: A snapshot of asylum seekers' housing and settlement experiences in Canada and the United Kingdom,' Journal of Immigrant 8 Refugee Studies 8(1), pp. 4-31.

Korac, M. (2003). 'Integration and how we facilitate it: A comparative study of the settlement experiences of refugees in Italy and the Netherlands,' Sociology 37(1), pp. 51-68.

Larruina, R. \& Berg, R. (2018). European Migrant Advisory Board: Initial Footsteps: January-June 2018. Unpublished report, Institute for Societal Resilience, Refugee Academy, VU Amsterdam.

Larruina, R., Boersma, K. \& Ponzoni, E. (2019). 'Responding to the Dutch asylum crisis: Implications for collaborative work between civil society and governmental organizations,' Social Inclusion 7(2), pp. 53-63.

Laws, J. L. (1975). 'The psychology of tokenism: An analysis,' Sex Roles 1, pp. 51-67.

Lilja, M. \& Vinthagen, S. (2014). 'Sovereign power, disciplinary power and biopower: Resisting what power with what resistance?' Journal of Political Power 7(1), pp. $107-126$.

Lukes, S. (1974) Power: A Radical View. London: Macmillan Press.

Moeran, B. (2009). 'From participant observation to observant participation,' in Ybema, S., Yanov, D., Wels, H. \& Kamsteeg, F. (Eds.), Organizational Ethnography: Studying the Complexities of Everyday Life. London: Sage, pp. 139-156.

Open Society Foundations (2019). The Open Society Foundations Work to Build Vibrant and Inclusive Democracies whose Governments are Accountable to their Citizens. Available at: www.opensocietyfoundations.org/

Partnership 5. Interviewed by Rinske Berg, 25 May 2018.

Partnership 6 Interviewed by Rinske Berg, 30 May 2018.

Partnership 7 Interviewed by Rinske Berg, 31 May 2018.

Partnership 8 Interviewed by Rinske Berg, 31 May 2018.

Partnership 9 Interviewed by Rinske Berg,1 June 2018.

Partnership 10 Interviewed by Tineke Postma, 31 January 2018.

Partnership 11 Interviewed by Tineke Postma, 31 January 2018.

Rast, M. \& Ghorashi, H. (2018). 'Dancing with "the other": Challenges and opportunities of deepening democracy through participatory spaces for refugees,' Social Inclusion 6(1), pp. 188-198.

Said, E. (2001). Reflections on Exile and Other Essays. Cambridge, MA: Harvard University Press. 
Scholten, P. (2018). 'Beyond migrant integration policies: Rethinking the urban governance of migration related diversity,' HKJU-CCPA 18(1), pp. 7-30.

Scholten, P., Baggerman, F., Dellouche, L., Kampen, V., Wolf, J. \& Ypma, R. (2017). Policy Innovation in Refugee Integration?Rotterdam, Netherlands: Erasmus University Rotterdam.

Schrover, M. L. J. C. (2010). 'Pillarization, multiculturalism, and cultural freezing: Dutch migration history and the enforcement of essentialist ideas,' BMGN: Low Countries Historical Review 125(2/3), pp. 329-354.

Simmel, G. (1950). The Sociology of Georg Simmel (Translated by Kurt Wolff). New York: Free Press.

Urry, J. (2007). Mobilities. Cambridge, UK: Polity Press.

Voorberg, W., Bekkers, V. \& Tummers, L. (2013). 'Embarking on the social innovation journey: A systematic review regarding the potential of co-creation with citizens,' paper for the IRSPM Conference, Prague, April 10-12.

Wilson, F. \& Thompson, P. (2001). 'Sexual harassment as an exercise of power,' Gender, Work $\mathcal{G}$ Organization 8(1), pp. 61-83.

Yanow, D. \& Schwartz-Shea, P. (2015). Interpretation and Method: Empirical Research Methods and the Interpretive Turn, 2nd edn. New York: Routledge.

Young, I. (2006). Inclusion and Democracy. Oxford: Oxford University Press.

Zanoni, P. \& Janssens, M. (2007). 'Minority employees engaging with (diversity) management: An analysis of control, agency, and micro-emancipation,' Journal of Management Studies 44(8), pp. 1371-1397.

Zapata-Barrero, R., Caponio, T. \& Scholten, P. (2017). 'Theorizing the local turn in the governance of immigrant policies: A multi-level approach,' International Review of Administrative Sciences 83(2), pp. 241-246.

Zimmer, L. (1988). 'Tokenism and women in the workplace: The limits of genderneutral theory,' Social Problems 35, pp. 64-77. 


\title{
10 Being a 'refuge-city' \\ Welcoming rhetorics in Paris and \\ Barcelona
}

\author{
Louise Hombert
}

\section{Introduction}

In September 2015, the European media and politicians were focused on one issue: the migration 'crisis' and its 'waves of migrants and refugees' flooding into Europe. The arrival of these asylum seekers in Europe was labelled a 'crisis': a violent phenomenon, presented as emerging from nowhere, which disrupted the balance of a well-organized system of actors. However, the politicization of this problem remained relatively superficial at the national levels. In response to the 'crisis,' some cities started to get involved. As the first to be concerned by refugees and migrants' arrivals (e.g. inadequate accommodation infrastructure, saturated administrative, legal and health services, etc.), they did not want to be responsible for a social failure. They chose to receive refugees and to take charge of the problem, while denouncing the state and European wait-and-see attitudes. They then called themselves not only 'refuge cities,' but also 'solidarity cities,' or 'welcoming cities.' At the same time, Europe was facing a rise in political extremism in many countries, particularly in response to the arrival of migrants: the breakthrough of Alternative für Deutschland (AfD) in Germany, Jobbik and Fidesz in Hungary, the Northern League in Italy, and the National Rally ${ }^{1}$ in France. These extreme right-wing movements have many faces and promote different values, such as nationalism, xenophobia, and Euroscepticism. In this context, it is interesting to question the openly inclusive stance of the refuge cities, which claim to be 'humanists.'

But what is humanism and what are the values associated with it? Although there are some debates about the very origin of the term (Vesperini 2015), this chapter will focus on the contemporary ethics the term implies. Its most common contemporary meaning can be defined as follows: humanism is 'a doctrine that is both theoretical and practical, laying down in principle the inalienable dignity of every human person and aiming to provide everyone with the conditions for their full development and to defend them against all political, legal, moral, economic and other attacks' (Morfaux 1980: 150). The analysis will be built on this definition. What would then be humanist values? Obviously, there is no fixed or exhaustive list. At a 
minimum, a fundamental tenant of humanist behavior includes respect of individual's dignity. Then follows the question of protecting others against all forms of oppression and injustice. Implicitly, humanism is therefore supported by a form of compassion or intrinsic empathy for others, through this shared human condition, common to all.

To analyze these welcoming cities' positions, I will compare Paris and Barcelona. I will examine the different rhetorics these cities have mobilized to talk about the context of European migration and the reception of migrants in their respective territories. These two metropolises, represented by their city councils and mayors, refer to many humanist values, such as humanity, dignity of all, or respect for human rights, and both call themselves 'refuge cities,' yet their migration situations are very different, as are their political contexts. The challenge is then to understand whether or not being a 'refuge city' has the same meaning and stakes for both Paris and Barcelona.

To address these questions, I have analyzed local executives' speeches, a collection of the public communications of the Mayor of Paris, Anne Hidalgo, and the Mayor of Barcelona, Ada Colau, as well as speeches of some of their deputies. The main materials are media interviews, excerpts from city council debates, and posts on Facebook, published between 2015 and 2018. The lexicometric analyses have been supplemented by an ethnographic inquiry carried out in 2017 and 2018 in Paris and Barcelona, including interviews with local elected officials, members of associations, and citizens' groups. It was important to also listen to the speeches of the other actors organizing the reception. Associations and groups of citizens, by working on the ground, can have a different conception of the refuge-city concept and the welcoming process. It was therefore interesting to meet with these organizations to question the reception of political speeches and their construction of the refuge-city, with all the values it implies. All of the statements made by respondents and the extracts from the corpus reported here are personal translations from French, Castilian, or Catalan into English. Theoretically, this analysis is rooted in three fields of research: the local governance analysis; the sociology of political discourse, focusing on the strategic approach; and, finally, the research on moral economies.

After having observed the words of welcome in the two cities, by taking a close look at the keywords and the main lexical fields mobilized, the differences and similarities between Barcelona and Paris will be analyzed in the second part of this chapter. Although both do not use the same rhetoric, but they have similar objectives.

\section{Speaking of welcoming}

What does it mean to be a 'refuge-city?' And to be 'welcoming?' This first part focuses on the speeches made by the municipal teams of Paris and Barcelona. The set of texts (from 2015 to 2018) is made up of: 52 city 
council's debates, both in Paris and Barcelona (with Ada Colau, Anne Hidalgo, and their deputies speaking); 59 Facebook posts (only Ada Colau and Anne Hidalgo's official pages, no deputy mayors'); and mayors' press interviews. In order to better understand, the uses of the employed words, each sub-section will begin with a description of the local context, in which these speeches have taken place.

\section{The keywords}

Keywords are the cornerstones of political speeches. The following part concentrates on the terms - essentially nouns and adjectives - that are most commonly used in the speeches of the two mayors and their deputies. To analyze the keywords, a statistical analysis has been carried out to find out the frequency of each word used.

\section{Hospitality, dignity, humanity: the Parisian tryptic}

The issue of migrants' reception has been debated in France for several years now. A quick recall of the contemporary economic and political context is necessary here. Since the economic crisis of 2008, France has been slowly recovering: the unemployment rate was still 8.9 percent at the beginning of 2018, which is close to what the country had experienced in the early 2000s (Institut National de la Statistique et des Etudes Economiques 2018). At the same time, as elsewhere in Europe, nationalist-populist discourses have gained prominence in the public sphere. Although the National Rally vote in Paris has remained much lower than in the rest of France, it has nevertheless increased in recent years (Auffret 2015). In this context, the voice of the Parisian municipality has been divergent, promoting a welcoming policy, thus involving new expenditure for recently arrived migrants. Let us take a closer look at the public speeches made by the Parisian executives. After reading the City Council's debates, press interviews, and the Facebook publications of the Mayor of Paris and her deputy Dominique Versini, certain keywords stand out in their speeches, including 'humanity,' the duty of 'hospitality,' or 'dignity/indignity.' The following excerpts attest to this:

Anne Hidalgo, Mayor of Paris:

Together, we will fight without respite, so that Paris may prove worthy of all Parisians, so that it may remain a refuge-city, fair, humane, and solidary.

(Hidalgo 2015)

We can all be proud of this dignified and humane system, which prevents street camps and is faithful to our tradition of welcoming people.

(Hidalgo 2017) 
The tradition of hospitality in our city has been respected, and we have put an end to the undignified mass camps in the streets of Paris.

(Hidalgo 2018)

Dominique Versini, Deputy Mayor of Paris:

We must keep in mind humanism [...] I plead for the government to have a humanist policy, and I think we now need to put a little more humanity here.

(France Info 2018)

The issue of dignity and indignity is central to the Mayor of Paris' speeches, particularly in her Facebook posts. Indeed, 'dignified' and 'undignified' are among the four adjectives most used on this social network by Anne Hidalgo, just after 'humanitarian' and 'Parisian,' while at the City Council, the main adjectives are those of 'minor' and 'young.' This difference can be quite simply explained by the fact that the debates of the City Council, although public, are not speeches intended for the whole of society: they are mainly debates between elected officials and administrative representatives intending to vote on the city's political programs. The statements therefore focus primarily on questions of legal competence and whether the reception of unaccompanied young people and minors, among others, is the responsibility of the city. Facebook appears here as a space dedicated to freer and more personalized political communications (Enli \& Skogerbø 2013), where humanist values are more present, especially the question of dignity and indignity that is specific to the Paris case. Indeed, these words are almost always used to qualify the makeshift camps that appeared in 2015 in the Parisian streets as a result of overcrowding of the reception and asylum systems. Between 2015 and 2019, tens of thousands of people passed through these camps, including asylum seekers, refugees, rejected asylum seekers, individuals subject to the Dublin Regulation, and people in transit seeking to reach other countries. Most of them came from Afghanistan, Eritrea, or Sudan. In April 2019, there were 1,300 people living in two major makeshift camps in Porte de la Chapelle and Porte d'Aubervilliers in the North-East of Paris.

\section{Human rights and European solidarity: Barcelona's priorities}

Although Paris and Barcelona share the same title of 'refuge city,' there are important differences in the way that they deal with the issue of welcoming migrants. This matter has not been as much debated in the capital of Catalonia as it has been in Paris. Local public opinion has seemed to be relatively favorable to reception, as evidenced by the 'Volem Acollir' ('we want to welcome' in Catalan) demonstration on February 18 2017, which brought together more than 160,000 people. It was the largest demonstration in favor of migrant and refugees' reception in Europe. Ada Colau's welcoming speech seemed then less disruptive in this 
local framework than Anne Hidalgo's one in Paris, also because of Catalonia's recent history and political and economic context. Indeed, since the late 1990s, Catalonia has experienced a new wave of migration, now composed of foreignborn people: there were only Spaniards in the previous migratory periods, in the 1920s and 1960s. According to Núria Franco i Guillén, 'Catalonia is the Autonomous Community of Spain that welcomed the largest number of immigrants' from 1998 to 2009 (Franco i Guillén 2011: 84). Moreover, unlike France, Spain was until very recently one of the European exceptions, with no openly far-right political movements or major xenophobic and nationalist movements (González-Enríquez 2017). The words chosen by the Mayor of Barcelona and her deputies in charge of migration issues are then somewhat different from those of the Mayor of Paris, as shown in the following quotes: Ada Colau Ballano, Mayor of Barcelona:

Although this falls within the competence of the States and Europe, we will do everything in our power to participate in a network of refuge cities. We want cities committed to human rights and life, cities we can be proud of.

(Colau Ballano 2015a)

Europe is at a crossroads and must choose between welcoming people seeking refuge or welcoming new forms of fascism and xenophobia.

(Colau Ballano 2016a)

Today, on the occasion of Europe Day celebration, I would like to share this message of gratitude, because if there is a Europe for which it is worth fighting, it is in Lampedusa, Lesbos, Athens, in all those places that defend life and give the rest of Europe a lesson in humanity.

(Colau Ballano 2016b)

we are deeply ashamed to see how homeless people die trying to save their lives at the doors of our home. Barcelona has been prepared for months to welcome people who do not come because of dehumanized policies [...] I am proud of a city that rebels against injustice and is organized to show the world its commitment to life and human rights.

(Colau Ballano 2016c)

Echoing the words of Paris' mayor quoted above, these extracts from Ada Colau's speeches testify to the same claim of humanism, through references to 'human rights,' 'the protection of 'life,' the struggle against 'dehumanized policies,' and 'injustice.' However, the keywords in Ada Colau's language are not the same as in Anne Hidalgo's. Indeed, a statistical analysis of the word occurrences shows a clear presence of the terms 'European,' 'municipal,' and 'international' among the ten most used adjectives, alongside the terms 'humanitarian,' 'solidarity,' and 'humane.' This reflects a broader geopolitical contextualization of this 
issue of migrants' reception in Barcelona: this is a European - if not a global challenge in which cities have a role to play. No reference to the question of dignity is made here, unlike in Paris, which seems to underline how much this term is linked to the issue of camps in the French capital, a problem that Barcelona does not have. In contrast to other major European cities such as Rome or Berlin, Barcelona has not experienced a similar influx of asylum seekers and refugees coming from Africa or Middle East. A real increase began a bit later, in 2017, and accelerated when Spain became the first country of entry for migrants to Europe in 2018 and when the political situation in Venezuela deteriorated. According to the Service of Attention to Immigrants and Refugees of Barcelona (SAIER), asylum applications in Barcelona have increased fivefold in three years, from 1,374 in 2015 to 7,433 in 2018 (Congostrina 2019). In 2018, most of the applicants came from Venezuela, Colombia, and Honduras.

\section{Analysis of lexical fields: the importance of values}

The analysis continues by no longer focusing on the welcoming keywords only but also on the lexical fields used to describe this willingness to welcome. The aim here is to know more about the place values occupy in these speeches. To achieve this, a lexicometric test was realized via the Reinert method in IRaMuTeQ software. The objective here is to propose a classification of the texts according to the proximity of the lexicon that composes them. The resulting terminal classes therefore represent sets of sentences that tend to contain the same words. This analysis makes it possible to identify the main themes addressed in our previously mentioned text compilations.

\section{Paris: staying pragmatic}

In the Parisian case, the Reinert method revealed four classes of discourse, or four themes regarding reception of migrants and refugees.' They are represented in the form of the dendrogram below. It presents the most specific terms of each theme obtained (according to the Chi2 statistics): the larger the font size and the higher the words in a column, the more representative they are of this theme.

Our four classes are divided into two branches, corresponding to two main categories: political actions to the left, and context description to the right. The analysis starts from the left of the dendrogram to the right.

Classes one and two represent the actions and concrete measures carried out in the city. More precisely, class one concerns the 'sheltering' [mise à l'abri] operations coordinated by the Police Prefecture to send migrants gathered in makeshift camps erected in public places to accommodation centers. From 2015 to 2018, nearly 35 sheltering operations were carried out, but the reappearance of new camps was not resolved in a sustainable manner. In addition, the term 'sheltering' is particularly relevant to institutional discourse. Many refugee activists and citizens' groups prefer to speak 


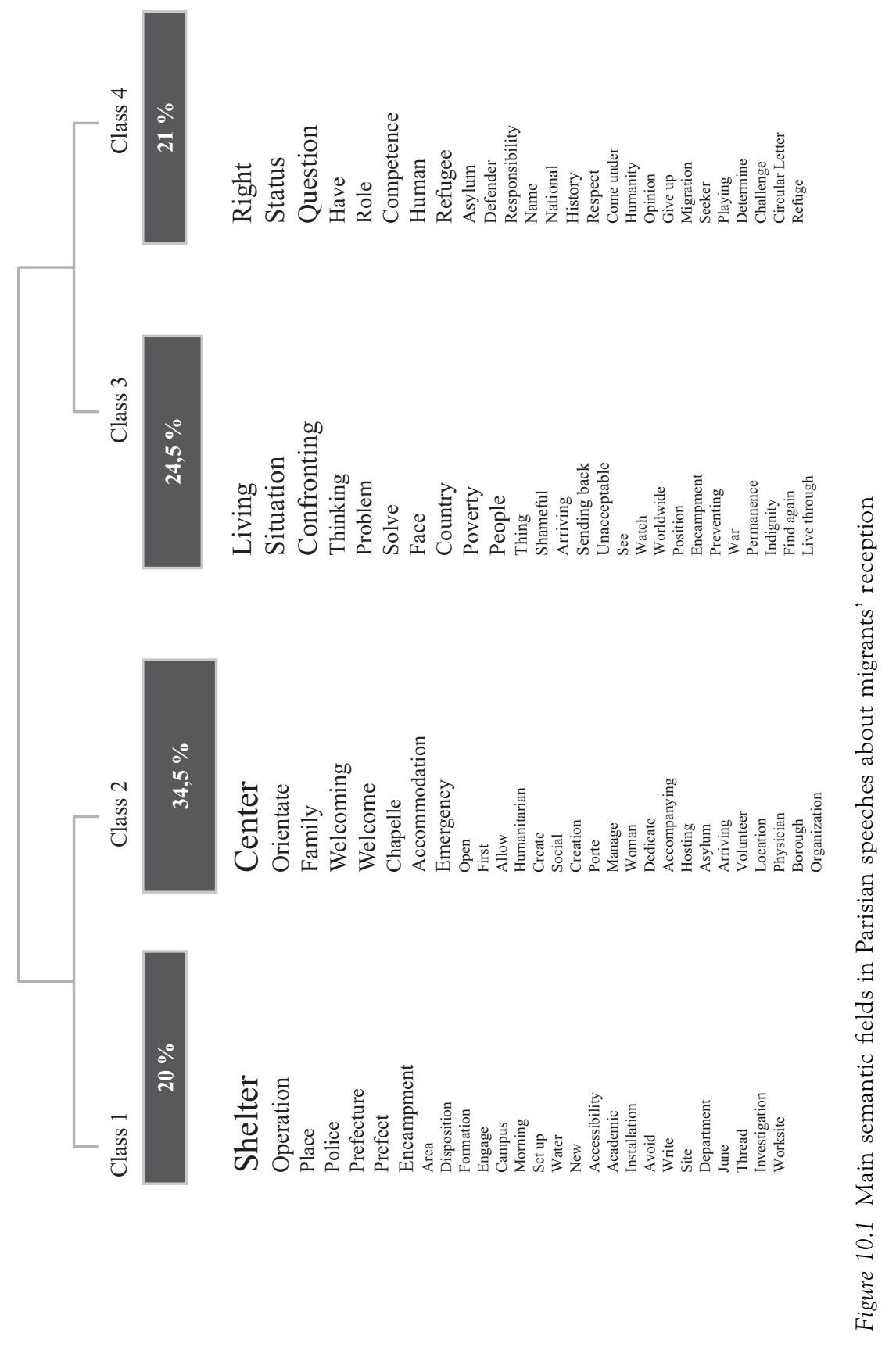


of 'evacuation' or even 'roundups,' in view of the number of people who did not receive accommodation after these operations, or who were taken to an administrative detention center (Centre de Rétention Administrative). Using the term 'roundup' [rafle] is very meaningful: in French history, it has been used to refer to the sudden and massive deportations of Jews to concentration camps during the Second World War.

Class two concerns the Centre de Premier Accueil (CPA), also known as the Humanitarian Center, which was established in November 2016 near Porte de la Chapelle and closed in the spring of 2018. This center, initially comanaged by the City of Paris and two associations, Emmaüs and Utopia 56, was the embodiment of the City of Paris' desire to welcome people, since it set up this project without the support of the State, at least initially. The aim of this center was to welcome migrants (mainly single $m^{2}{ }^{2}$ ) for a few days, before referring them to the appropriate social measures, depending on their administrative situation. This was the first center of its kind to be opened in France. Nearly 25,000 men passed through it during the time it was open.

Then, classes three and four represent the contextualization values. Class three offers a description of the humanitarian context: 'misery,' 'unworthy,' 'unacceptable,' 'war,' 'camp.' Class four corresponds to an imperative for action with plural justifications: 'law,' 'responsibility,' 'defender,' 'history,' 'refuge,' 'challenge,' and 'humanity.' These two classes constitute 45.5 percent of the public speeches analyzed here, which allows us to observe how important the values mobilized to describe the situation are in close relation to concrete action mechanisms: almost as much speaking time is devoted to one as the other.

However, it would be overly simple to separate here our two main categories with 'action' - via devices - on the one hand, and 'speech' - via simple context descriptions - on the other. On the contrary, it is worth emphasizing the performative dimension of language, in particular of the institutional language studied by Bourdieu. In his work Language and Symbolic Power (1991), Bourdieu underlines the fact that, when an institution speaks through its officials, the simple process of appointing an object leads to a construction of reality. Producing a speech structures the worldview of the agents who listen to it, and in return, structures the world itself when these agents consider it legitimate and therefore adhere to it. Yet the effectiveness of this institutional language cannot be understood without the very authority of the institution from which it emanates. It is thus thanks to the symbolic power vested in the spokesperson, as the representative of the institution, that the latter can produce a performative speech. This analysis of institutional language allows for a better understanding of the important place of descriptive values in the Mayor's communications: to build a 'welcoming city,' Anne Hidalgo or her deputies must mobilize humanist values to describe the context in which the actions of the city are embedded - here 'unworthy,' 'humanity,' 'respect,' and 'refuge.' The next part will question how important this institutional language is in Ada Colau's speeches. 


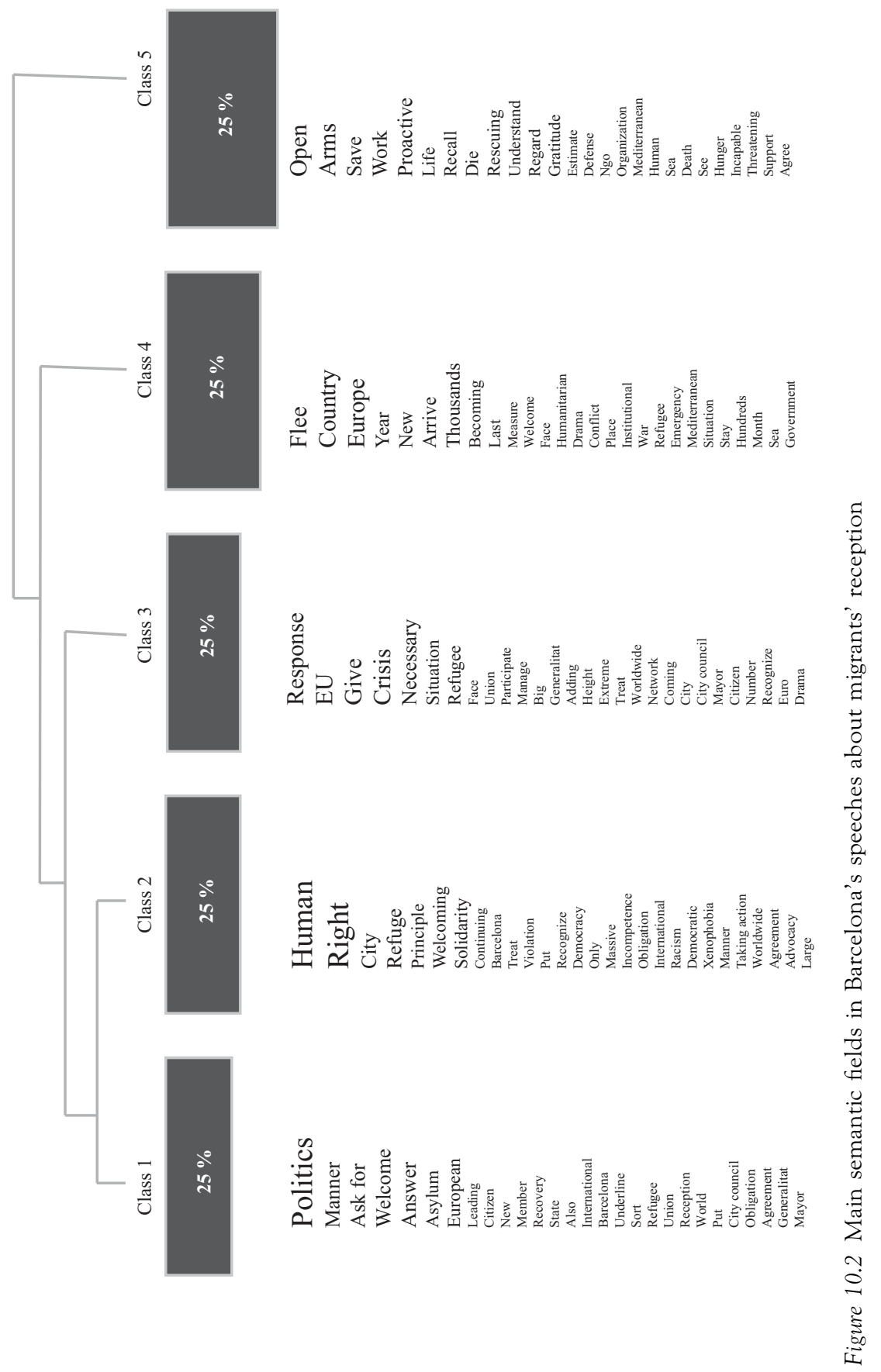


Barcelona: for a freer voice

The same lexicometric analysis was applied to the quotes compiled for Barcelona's case, and the results are as follows:

The dendrogram above shows five thematic classes. Class five is separate, concerning migrants rescued in the Mediterranean and more specifically the NGO Proactiva Open Arms. Class four represents the overall humanitarian situation - 'flee,' 'conflict,' 'drama,' 'humanitarian,' 'emergency,' while classes one, two, and three concern the political sphere. More precisely, class three corresponds to political denunciation - 'crisis,' 'situation,' 'necessary,' 'EU.' Then, classes one and two are the political responses: class one concerns the global political system - 'political,' 'subject,' 'asylum,' 'European,' 'State,' - and class two concerns the justifications for political action 'refuge,' 'welcoming,' 'solidarity,' 'obligation,' 'democracy,' 'racism,' and 'human right.'

This lexicometric analysis confirms the first leads identified by the occurrence analysis. Here the classes of this dendrogram represent much more general themes than in the Parisian case. Apart from class five and the terms 'Barcelona' or 'Generalitat,' nothing links the corpus to a specifically Barcelonaese or even Spanish situation, while half of the thematic classes in Paris concerned the local context. The values mobilized by the Mayor of Barcelona contain a more global, universal dimension, and they are also more diffused in each class. Class three remain the most substantial. Through the significant mobilization of references to 'Europe,' Ada Colau and her team's speeches place the question of welcoming people within a broader issue: Europe's values. They strongly underline the opposition between, on the one hand, respect for human rights and solidarity, and on the other hand, the EU's inaction accompanied by the rise of xenophobia and nationalism. This argumentative rhetoric is very rarely present in Paris' municipal team's statements. However, these two metropolises are largely united in the mobilization of the humanist register, making extensive use of the terms 'humanity,' 'humane,' 'solidarity,' and insisting on the duty to 'welcome' and to be a 'refuge.'

\section{Being welcoming, but what for? Understanding the different refuge-cities rhetorics}

The common points and specificities of each public speeches' compilation have been precisely detailed in the first part of this chapter. Although our two refuge cities promote the same humanist values, their rhetoric is not quite the same. The second step is to understand these differences and observe the objectives sought by these processes. 


\section{Two cities that do not speak the same language: contextualizing values}

The analysis of the speeches allowed us to highlight nuances and gaps between the statements made by local executive authorities in Barcelona and Paris. Indeed, the former mobilizes more universal moral principles by placing them in a broader geopolitical context, while the latter links its values more closely to concrete local issues. Let us look for a moment at the factors explaining these differences.

First of all, a key factor is the migratory and humanitarian situation of each city. As it has already been emphasized, Paris has been facing a problematic humanitarian situation since 2015, with the emergence of squalid makeshift camps on its streets. At the beginning of January 2019, over 2,000 exiles were reportedly spread over three main camps in the northeast of the capital. There is therefore a real local issue regarding housing and access to vital resources (water, food, care) for migrants, which explains the references to the principle of 'dignity' (or 'indignity') in the executive's' remarks. However, these problems are not encountered in Barcelona. For instance, in the autumn of 2015, when the Parisian reception facilities were overcrowded, Barcelona's executives demanded asylum seekers and refugees be sent there in Catalonia. No makeshift camps similar to the Parisian ones were set up there, and, until the summer of 2018, the reception facilities did not yet have any real problems of being too small. These differences therefore highlight the gap between a more generalist discourse in Barcelona, which places its action in a global European situation, and a more specific discourse in Paris, where local issues are at stake.

A second explanatory factor is the local public opinion. The inhabitants of Barcelona seem to be rather in favor of welcoming refugees, as indicated by the important demonstration of February 2017, Volem Acollir, mentioned earlier. In this context, Ada Colau could allow herself to promote hospitality. This is illustrated by the following excerpt from one of her Facebook publications:

The day before yesterday, 50 people died of asphyxiation in a ship's hold. Yesterday, more than 70 people died in a truck. Today, we woke up with two shipwrecks: perhaps more than a hundred dead. We have a sea full of dead people. Borders full of barbed wire, spikes, blades ... and dead people.

Men, women, boys, and girls, dead.

And part of Europe cries, screams, wants them to be saved, not to die, but ... but not to come, to leave, to disappear, not to exist and not to have to see them on television, and even less on our streets, with their blankets, in the underground or on the stairs of our houses.

Some people irresponsibly promote fear 'of others,' 'of illegal immigrants,' 'of those who come to sell without a permit,' 'of those who come to take advantage of our health system.' 
But that's all fear is: fear. Our fear of living a little less well against their fear of not surviving. Our fear of having to share a small part of our well-being against their fear of hunger and death.

Fear versus fear. And theirs is stronger. So, Europe, Europeans: let us open our eyes. There won't be enough walls or barbed wire to stop it. No tear gas, no rubber bullets. Either we approach a human drama with the ability to love that makes us human, or we will all end up dehumanized.

(Colau Ballano 2015a)

These are the first comments the Mayor published on her Facebook page about the migration situation, at a time when the City was receiving hundreds of messages from its fellow citizens asking how they could help migrants (Respondent 1 2018). This pro-reception and very active part of Barcelona's population has thus allowed Ada Colau to freely mobilize a certain lyricism and pathos that are not found in Anne Hidalgo's remarks. On the contrary, in Paris, the question of reception creates significant tensions, mainly via the question of makeshift camps which are located in neighborhoods already suffering from many socio-economic problems. As a local elected official explained (Respondent 2 2018), the aim in Paris is to run with the hare and hunt with the hounds, between the ambitions of humanist welcome and solidarity, and the 'legitimate' claims of the inhabitants not to welcome 'again' poor and immigrant populations in already disadvantaged neighborhoods. Parisian citizens seem more divided on the reception issue than in Barcelona. Thus, the mayor of Paris sticks to a more factual, pragmatic discourse, basing it on the actions carried out in the city to resolve the humanitarian situation, hoping to satisfy those who wish to see migrant camps disappear, whether for compassionate reasons or for rejecting ones.

Among the factors that explain the differences between the discourses, speakers' backgrounds should be taken into account. Both cities were then run for the first time by women, who tended to strongly embody their city and personalize their mandates. Therefore, their words are significant, because they actively participate in the construction of their cities' identities. Analyzing their backgrounds is useful to understand the different types of discourse that each can mobilize. Indeed, the two mayors are quite far apart on this point. Anne Hidalgo can be considered a political professional: after studying law and social sciences, she passed the civil service exams to become a labor inspector, then worked in various ministerial cabinets under Lionel Jospin's government. Before becoming Mayor in 2014, she was first Deputy Mayor of Paris and Regional Councillor for the Île-de-France region (Bacchi 2014). Socialized for a long time in this professional environment, her discourse is therefore more institutionalized than that of Ada Colau, who has recently joined politics. The Mayor of Barcelona has not had a traditional political career. Before arriving at Barcelona City Hall, she was above all an activist, particularly known for having been the spokesperson 
for the Plataforma de Afectados por la Hipoteca, an organization that prevented thousands of evictions of over-indebted families during the 2008 economic crisis. Prior to that, she was involved in anti-globalization and anti-Gulf War and Iraq war movements (Sust 2013). Her political career therefore began with her position as Mayor of Barcelona in 2015. Claiming to be herself 'daughter of emigrants' (Colau Ballano 2015b), Ada Colau then proposes an 'unfiltered' speech, an activist speech from her militant trajectory, particularly on social networks.

The analysis conducted here has highlighted the importance of the link between the context and the mobilized values: although humanism is based on broad and fairly general ethical principles, the values it promotes are linked to specific situations.

\section{The aims of humanism}

Despite their lexical differences, Anne Hidalgo, and Ada Colau's speeches tend towards the same objectives. We can see positioning their respective cities as humanist 'refuge cities' as a double political opportunity for these metropolises: first, to regain local legitimacy and assert themselves in the face of central power; and second, to become a political actor on the international scene.

First of all, and as was pointed out in the introduction, it should be recalled that immigration remains a state prerogative both in Spain and France. So, by denouncing the inaction or shortcomings of the central government and by setting up new reception systems that complement national systems, these two cities are asserting a strong political role in this 'crisis.' In this context, public speech is essential to accompany and legitimize political acts not provided for in the national legal framework. We can see here an attempt to create a new system of norms and values, by emphasizing humanism, solidarity, mutual aid, or dignity of all. This system of 'collective consciousness' (Becquart-Leclercq 1977: 230a) can be a mean of rediscovering a form of political legitimacy for local power: 'specified and objectified, this system of norms becomes a 'paradigm' (Becquart-Leclercq 1977: 230b). The local power legitimacy then comes from a 'concordance between a concrete power and a power paradigm.' Barcelona and Paris correspond to this framework of interpretation, with on the one hand, a 'concrete power' they hold from the law and that they use by taking significant and visible measures such as the Centre de Premier Accueil and the Nausicaa program, ${ }^{4}$ and on the other hand a value system they have objectified in their speeches and more particularly in their two official 'plans': the Barcelona, ciutat refugi plan, published in September 2015, and the Mobilisation de la communauté de Paris pour l'accueil des réfugiés plan, published in October 2015. These two plans formalize the rhetorics we have analyzed above and thus constitute 'power paradigms,' supporting the legitimacy and the necessity of local reception. 
Then, such systems based on humanist values can allow the production of a certain form of consensus. It is indeed difficult to speak out 'against' solidarity or respect for human rights, for instance. According to Didier Fassin (2012: 3), 'this language has become established today as the most likely to generate support among listeners or readers.' Thus, by mobilizing these values, our two refuge-cities bring together a group of actors from various positions, sometimes belonging to the political opposition, around this issue of humanist reception, which can be then analyze as an 'urban project,' according to Gille Pinson's conception. For this researcher, 'the notion of project refers to situations in which collective action is organized around relatively small groups of actors, mobilized to solve a specific problem or to deal with the difficulties of a circumscribed territory, over a limited period of time' (Pinson 2005: 200a). It is therefore a public 'mode of action' (Pinson 2005: 200b) in itself that makes it possible to create a new collective actor by uniting a whole set of organizations around common principles and constructions, around an identity. This strong identity dimension of the project functions as a unifying background framework between the actors. It is in this sense that project dynamics become an 'instrument of social mobilization' (Pinson 2005: 201): the humanist values used to describe the project are considered relatively consensual in Western societies and therefore serve here to federate, to unify.

The rhetoric of hospitality can also be a challenge in political arenas, both nationally and internationally. Indeed, at the national level, in France and Spain, governments have not particularly taken up the issue of welcoming refugees to build up a humanist and generous image. On the contrary, various institutions - such as the Rights Defender in France (Défenseur des droits 2018), or the European Court of Human Rights for Spain (European Court of Human Rights 2017) - have been able to denounce significant violations of the fundamental rights of migrant persons, rights of which the States are a priori the guarantors. By playing on the register of values and feelings, the cities of Paris and Barcelona clearly distance themselves from the governments' discourse, which is more based on legal or security logics. This gives these two cities an image of being a more sensitive, and more humane public actor within national political arenas. Finally, holding this type of compassionate discourse enables the cities to align themselves with a group of cities and metropolises in Europe that make similar statements. It is thus possible to find support, recognize allies, and set up inter-urban mutual assistance systems on reception issues, as Ada Colau had wished to do, for example, with the mayors of Lesbos, Lampedusa, and Athens in March 2016 (Gonzalez 2016). But there is also some competition for the spotlight, with several cities, including Paris and Barcelona, claiming to be pioneers in welcoming migrants and thus hoping for symbolic repercussions through the creation of a particularly solidary, generous, and therefore honorable, image. 


\section{Conclusion}

Following this analysis, initial conclusions on the welcoming rhetorics in the metropolitan areas of Barcelona and Paris can be presented, allowing for a better understanding of what the expression 'refuge-city' means to them. As seen above, both have mobilized an important repertoire of words with high humanistic and ethical value, but each has emphasized different notions, such as 'dignity' in Paris, or 'solidarity' and 'human rights' in Barcelona. The explanatory factors of these nuances are obviously multiple, the first of them being the migratory and humanitarian context of each city, a decisive factor in determining the angle of approach to be prioritized. In Paris, it is a question of responding to the urgency created by makeshift camps, an urgency experienced by migrants, but also by some residents. Indeed, this critical situation has pushed Anne Hidalgo to talk about the solutions she has put in place, or wished to put in place, and to focus her speech on the duty of hospitality and respect for the dignity of all. This urgency is not present in Barcelona, therefore a freer discourse - especially in tone - is more permissible for Ada Colau, who can express herself on the whole reception problem at the European level, referring to multiple general ideals. We therefore have to deal with two rhetorics of welcoming that share their humanism, but which are nevertheless distinguished: one by its pragmatism, the other by its idealism. In both cases, however, they follow the same ambitions: to produce consensus, and to position the issuer in political arenas - local, national, and European.

However, local executives' speeches, and particularly their use of humanist ethics, have often been criticized by other actors, such as associations and citizens' collectives. They have denounced words without action and seen in them utilitarian ambitions among their authors. According to them, it would be a question of giving oneself a 'humanist varnish' as well as a 'good conscience' (Respondent $3 \& 4$ 2018). On Barcelona's side, the refugees' reception would above all be a pretext to 'be in the spotlight' (Respondent $5 \& 6$ 2018) and obtain a good image, in a very complex political arena divided around the question of Catalonia's independence. It is also a miserable vision of migrants that is denounced on these two fields, but mainly in Paris. The fact that mayors' speeches cannot be accepted by the actors on the ground underlines the limits of these rhetorics' mobilizing capacities. For many of these supportive citizens, welcoming rhetoric playing on ethical values are more than inappropriate here, especially in Paris where cases of police harassment against migrants are frequently reported (Human Rights Watch 2017; Dearden 2017).

\section{Notes}

1 Main far-right French party, formerly known as Front National (FN) until June 2018.

2 A second center was created in Ivry, a city close to Paris, reserved for women and families. 
3 The Generalitat de Catalunya is the political institution representing the autonomous community of Catalonia.

4 The Municipal reception program, called Nausica, was launched in 2015 to protect and provide shelter for asylum seekers and refugees who are excluded of the state care program (e.g. refused asylum request, end of the state care programme for refugees).

\section{References}

Auffret, S. (2015) 'Elections régionales: à Paris, le Front national en progression,' Le Monde 8 December. Available at: www.lemonde.fr/les-decodeurs/article/2015/12/ 08/a-paris-le-front-national-en-progression_4827310_4355770.html

Bacchi, U. (2014) 'Who is Anne Hidalgo, the First Female Mayor of Paris?' International Business Times, 31 March. Available at: www.ibtimes.co.uk/who-anne-hida lgo-first-female-mayor-paris-1442736

Becquart-Leclercq, J. (1977) 'Légitimité et pouvoir local,' Revue française de science politique 27(2), pp. 228-258.

Bourdieu, P. (1991) Language and Symbolic Power (trans. Gino Raymond \& Matthew Adamson). Cambridge: John B. Thompson Editions.

Colau Ballano, A. (2015a). 28 August. Available at: www.facebook.com/ada.colau/p osts/882375408509792

Colau Ballano, A. (2015b). Extract from the City Council debates, June 13, City Hall, Barcelona. Available at: https://ajuntament.barcelona.cat/sites/default/files/acta_130615_ca.pdf

Colau Ballano, A. (2016a). 11 December. Available at: www.facebook.com/watch/?v= 1205257826221547

Colau Ballano, A. (2016b). 9 May Available at: www.facebook.com/watch/?v= 1025269760887022

Colau Ballano, A. (2016c). 26 February. Available at: www.facebook.com/ada.colau/p osts/973448409402491

Congostrina, A. L. (2019). 'Las peticiones de asilo en Barcelona se quintuplican en tres años,' El País, February 12. Available at: https:/elpais.com/ccaa/2019/02/11/ca talunya/1549891883_321326.html

Dearden, L. (2017). "'Get out of France”: Paris police tear gassing refugees and stealing blankets in freezing conditions, report reveals,' The Independent, February 11. Available at: www.independent.co.uk/news/world/europe/refugee-crisis-paris-migra nts-france-police-sleeping-bags-blankets-violence-refugee-rights-data-a 7575376.html.

Défenseur des droits (2018). Exilés et droits fondamentaux, trois ans après le rapport Calais. Available at: www.defenseurdesdroits.fr/sites/default/files/atoms/files/rapp ort_calais-num-14.12.18_0.pdf

Enli, G. S. \& Skogerbø, E. (2013). 'Personalized campaigns in party-centred politics,' Information, Communication $\mathcal{E}$ Society 16(5), pp. 757-774.

European Court of Human Rights (2017). The immediate return to Morocco of subSaharan migrants who were attempting to enter Spanish territory in Melilla amounted to a collective expulsion of foreign nationals, in breach of the Convention. 3 October. Available at: https://hudoc.echr.coe.int/eng-press\#

Fassin, D. (2012). Humanitarian Reason: A Moral History of the Present, 1st edn. (translated Rachel Gomme). Berkeley: University of California Press.

France Info (2018). Video. Dominique Versini: 'Il ne faut pas laisser les migrants à la rue', January 16th. Available at: www.francetvinfo.fr/monde/europe/migrants/video-dom inique-versini-il-ne-faut-pas-laisser-les-migrants-a-la-rue_2565137.html 
Franco i Guillén, N. (2011). 'L'immigration en Catalogne dans le contexte espagnol: l'évolution de la démographie et des politiques publiques,' Migrations Société, 134-5 (2-3), pp. 83-93.

Gonzalez, B. (2016). 'Colau pacta traer a 100 refugiados desde Atenas,' El Periodico, 16 March. Available at: www.elperiodico.com/es/internacional/20160316/colau-pacta -traer-a-100-refugiados-desde-atenas-4981780

González-Enríquez, C. (2017). 'The Spanish Exception: Unemployment, inequality and immigration, but no right-wing populist parties,' Elcano Royal Institute, Working Paper, 2017(3). Available at: www.realinstitutoelcano.org/wps/portal/rielcano_en/con tenido?WCM_GLOBAL_CONTEXT=/elcano/elcano_es/zonas_es/imagen+de+espa na/wp3-2017-gonzalezenriquez-spanish-exception-unemployment-inequality-inmigra tion-no-right-wing-populist-parties

Hidalgo, A. (2018). 16 January. Available at: www.facebook.com/HidalgoAnne/posts/ 10155733480149597

Hidalgo, A. (2017). 14 February. Available at: www.facebook.com/HidalgoAnne/p osts/10154679389754597.

Hidalgo, A. (2015). Extract from the Municipal and Departmental Council Debates, March 16, 17 and 18. Available at: https://api-site.paris.fr/images/74400

Human Rights Watch (2017). Police Abuse Against Migrants in France Must Stop, January 13. Available at: www.hrw.org/news/2017/01/13/police-abuse-against-migra nts-france-must-stop.

Institut National de la Statistique et des Etudes Economiques (2018). Le taux de chômage diminue de 0,1 point au deuxième trimestre 2018. Available at: www.insee.fr/ $\mathrm{fr} / \mathrm{statistiques} / 3598305$

Morfaux, L-M. (1980). 'Humanisme,' in Morfaux, L-M. \& Lefrance, J. (eds) Vocabulaire de la philosophie et des sciences humaines. Paris: Armand Colin, p. 150.

Pinson, G. (2005) 'Le projet urbain comme instrument d'action publique,' in Lascoumes, P. \& Le Galès, P. (eds) Gouverner par les instruments. Paris: Presses de Sciences Po Académique, p. 199-228.

Respondent 1 (2018). Interviewed by Louise Hombert at Barcelona City Hall, October 4.

Respondent 2 (2018). Interviewed by Louise Hombert at $18^{\text {th }}$ arrondissement of Paris Town Hall, April 17.

Respondent 3 \& 4 (2018). Interviewed by Louise Hombert in Paris, January 31.

Respondent 5 (2018). Interviewed by Louise Hombert at Generalitat de Catalunya respectively at an association for housing for asylum seekers, November 6 \& September 25.

Sust, T. (2013). 'Ada Colau, activista de profesión,' El Periodico, February 12. Available at: www.elperiodico.com/es/sociedad/20130212/perfil-ada-colau-portavoz-pah-2316849

Vesperini, P. (2015). 'Le sens d'humanitas à Rome,' Mélanges de l'École française de Rome - Antiquité, 127(1). Available at: https://journals.openedition.org/mefra/2768 


\title{
11 Holding course
}

\section{Civil society organizations' value expressions in the Swedish legislative consultation system before and after 2015}

\author{
Roberto Scaramuzzino and Brigitte Suter
}

\section{Introduction}

Contrary to the general trend in European countries since the 2000s, Sweden has neither restricted its migration policy nor limited the rights of migrants. Indeed, the red-green coalition government that took office in 2014 was adamant about wanting to keep at least the status quo in its migration policy. In April 2015, the Swedish Prime Minister Stefan Löfvén, in a newspaper interview, declared that there was no limit to the number of asylum seekers Sweden could receive (Lönnaeus 2015), while in September of the same year, he declared 'my Europe does not build walls,' at a public solidarity manifestation for refugees in Stockholm (Regeringen 2015a). ${ }^{1}$ However, after receiving 80,000 asylum applications in two months, the government - together with regional and local authorities - reconsidered its stance. At a press conference in November 2015, Löfvén said 'It hurts me that Sweden is no longer capable of receiving asylum seekers at the high level we do today. We simply cannot do so anymore' (Regeringen 2015b), and went on to announce a number of drastic measures, all of which were designed with the explicit purpose to reduce the number of asylum seekers in the country. Such measures included the re-introduction of external border controls (as of November 2015), as well as limited family migration, and the issuing of temporary protection statuses instead of permanent ones (as of June 2016). The effects of these measures, the government argued, were also beneficial for the integration of the immigrants already in the country (Regeringens proposition 2015/16). Swedish 'exceptionalism,' thus, came to an abrupt halt (Emilsson 2018).

Swedish civil society organizations (CSOs) were considerably involved in the reception of newly arrived refugees during the so called 'refugee crisis' of 2015 and were able to mobilize funds, and volunteers both independently and in cooperation with public authorities (Turunen \& Weinryb 2017; Bevelander and Hellström 2019). After this clear and rather dramatic turnaround of the Swedish public authorities, the question is how civil society organizations have reacted and possibly adapted to the new policies. This chapter, thus, focuses on CSOs, and asks if, and in what way the events of 
2015 have changed the CSO's normative positions, both towards migration and integration. The chapter does so by exploring statements and opinions made by CSOs in the Swedish 'referral system,' i.e. the legislative consultation system [remissväsende].

The referral system is one of the most typical procedures of the Swedish legislative system for interest representation. It is a process of consultation in which organizations that have a stake in a specific policy area or issue can comment on drafts of legislation. These comments are addressed and taken into consideration by the responsible public authority (e.g. a particular department) in drafting the final document before it is submitted for voting in parliament. Serving as an important tool of democracy, through the referral system, the government invites stakeholders to comment on a legislative draft, especially with regard to the potential consequences of the implementation of the proposal. Furthermore, it promotes 'broad civic participation in the public debate' (Swedish government offices 2009: 5).

As most CSOs are driven by values (Anheier 2005) - whether their source is ideological, religious or cultural - we can expect their claims, comments, and statements on legislative drafts to be value-based. The Swedish term for civil society organizations - 'idea-based organizations' [idéburna organisationer] - in fact expresses this neatly. In this sense, in this chapter, values are understood as organizational values, closely linked to 'ideology': 'a system of multiple beliefs, ideas, values, principles, ethic, morals, goals, and so on, that overlap, shape, and reinforce one another' (Beck 2013: 1). They are often expressed through different advocacy strategies, such as lobbying politicians and civil servants, publishing statements on traditional and social media, staging street protests, and participating in consultation processes with public authorities.

This chapter sheds light on, first, the general norms and values of the CSOs, as expressed in the organizations' self-presentation and vision, or mission statements. In a second step, the chapter seeks to elucidate how these declarations of norms and values have made their way into the referral system within a selection of key legislative processes. Finally, the aim is to see whether the events of autumn 2015 (the 'refugee crisis') have led organizations to change their expressions of norms and values in the field of migration and integration.

\section{The CSOs and the legislative processes explored}

For our study, we have selected five central CSOs. They are among the organizations that have been most involved in migration and integration policy issues in Sweden in the last decades, both when it comes to advocacy and service. They also represent different organizational types and hence logics (Scaramuzzino \& Wennerhag 2019). Two of them are classic 'solidarity organizations,' the Red Cross [Röda korset], and Save the Children [Rädda barnen]. As solidarity organizations, rather than organizing and representing 
a particular social group, they engage in particular issues, such as human or children's rights. However, they also differ, as the Swedish Red Cross is more service-oriented, while Save the Children is more advocacy-oriented. Furthermore, we have chosen two typical 'interest organizations': the umbrella organization for ethnic associations SIOS (Samarbetsorgan för etniska organisationer $i$ Sverige) and the Swedish Women's Lobby (Sveriges kvinnolobby). As interest organizations, they organize and represent specific social groups and their interests, and they are both advocacy and service-oriented. SIOS is an umbrella organization representing federations of ethnic associations in Sweden. As an organization directly organizing and representing immigrants' interests, it has important stakes in the formulation of migration and integration policy. The Swedish Women's Lobby organizes women around issues of gender equality and women's rights. It is an umbrella organization for women's organizations, including women's shelters, and ethnic women's associations. As a representative of the last category of organizations, we have included one of the largest religious organizations in Sweden, the Swedish Christian Council [Sveriges kristna råd], which represents different Christian faiths (Lutheran, Orthodox, Catholic, and the Free Churches). These churches have been very active in advocating for migrants' and refugees' rights (Linde \& Scaramuzzino 2018).

We have also made a selection of consultation processes around four different policy proposals, two for each policy field: migration and integration respectively. In order to see whether there has been a change in the values and norms expressed by the CSOs, we have selected two proposals from before, and two from after 2015. The policy proposals selected were the ones that proposed the most significant policy changes in these periods; all of them have been highly debated in the political and public discourses. All legislative drafts have, after the remiss procedure and subsequent revisions, been approved by the parliament and have entered into force. A more detailed description of each proposal is presented later on in the chapter.

In the analysis of the comments made by the organizations through the referral system, we have looked at their statements, and by means of content analysis, we have explored to what extent they can be implicitly or explicitly related to particular values and norms. The norms and values expressed have then been compared across policy areas and periods of time.

\section{Migration and integration in Sweden}

While Sweden was one of the European countries that had a high proportion (one fifth) of its population emigrate to North America between 1850 and 1910, in the middle of the twentieth century, the country increasingly became a country of immigration. What started with mainly labor migration in the 1960s until the oil crisis in 1973, took the shape of refugee migration since the 1970s, and especially during the Balkan war in the 1990s. Refugee migration is still a significant part of yearly immigration, however, family 
reunification, labor migration, student migration, and intra-EU migration are also substantial parts of the immigration numbers. During 2015, almost 163,000 asylum applications were made, which was more than five times as many as during the previous years (European Migration Network 2016: 5). 2016 saw the highest number of first-time residence permits issued to more than 150,000 persons (for protection reasons, family reunification and family formation, labor immigration, and studies). This represents an increase by 32 percent compared to 2015, when roughly 114,000 individuals received a firsttime residence permit in Sweden (European Migration Network 2016: 1). As can be seen in Figure 11.1, since 2014, refugees have constituted the largest number of first-time permit holders, while, previously, labor migration, EU migration, and student migration dominated the statistics. The refugee category consists, to a considerable amount, of Syrian nationals - about 40 percent in 2013, 50 percent in 2014, 30 percent in 2015, and 25 percent in 2016. Other major asylum-seeking groups during this period were individuals from Iraq, Somalia, Afghanistan, and Eritrea (Migrationsverket 2019).

The foundations of the current integration policies can be found in the policy changes of 1998. Since that time, integration measures towards immigrants as a particular group have been restricted to the first 24 months after receiving a residence permit. In these first 24 months, the public system offers refugees and other migrants a language course, a civil orientation course, and labor market preparatory activities. Participants of this program receive a monthly 'salary-like' allowance. After this initial period, integration is mainstreamed, and the different governmental departments' various welfare policy measures should guarantee equal rights, duties and possibilities for all residents in Sweden (Brekke \& Borchgrevink 2007). Irrespective of

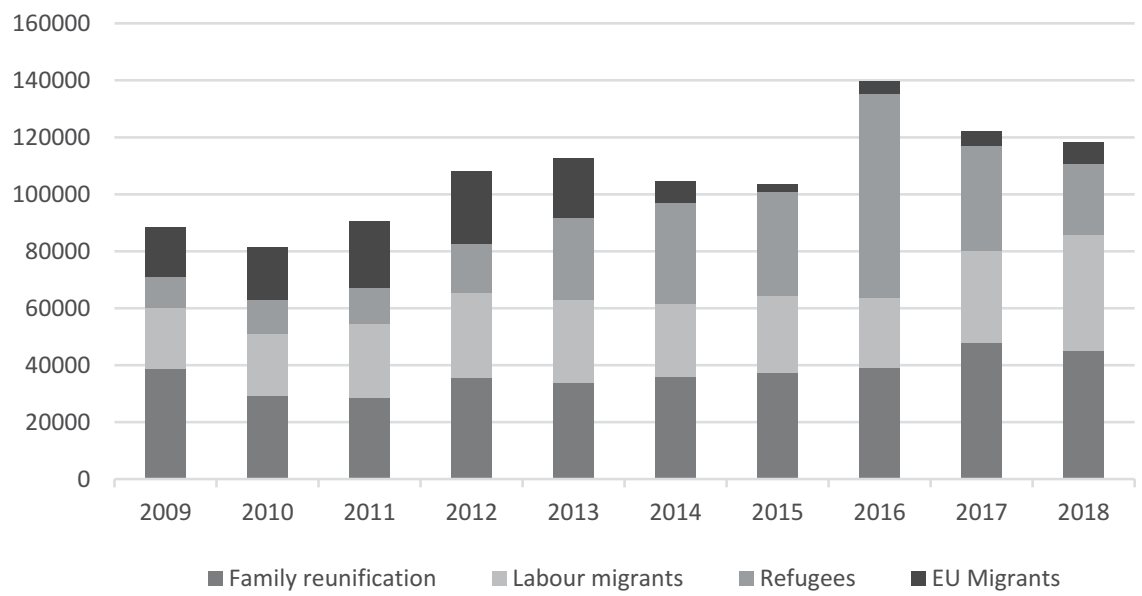

Figure 11.1 Number of residence permits issued in Sweden by category of immigration, 2009-2018

Source: Migrationsverket, 2019 
government coalitions, Swedish integration policy has predominantly been rather functional, with a focus of equal rights, duties and possibilities for everyone, irrespective of their ethnic and cultural background, and with a declared main goal to increase employment numbers among its foreign-born population (Suter \& Qvist 2012; Scaramuzzino 2012).

\section{Swedish civil society organizations and the political process}

Sweden has a long tradition of CSOs engaging in politics, including in issues of migration and integration (Scaramuzzino 2012). The organizations are mostly advocacy-oriented and consist of popular movements [folkrörelser] with an emphasis on membership, volunteerism, fostering citizenship, social relations, and strengthening democracy (Lundström \& Wijkström 1997; Micheletti 1995). They have played a significant role in representing groups of citizens, providing them with collective identities, making their voices heard, and influencing social norms. Furthermore, they play an important role in challenging the government concerning the rights of specific groups. Historically, they have been influential in pushing for workers' rights, women's rights, the rights of migrants, the elderly, and people with disabilities (Johansson et al. 2011; Feltenius 2008; Scaramuzzino 2012).

While CSOs in Sweden have mostly been advocacy-oriented rather than service-oriented, and funded by members rather than by the government (Salamon et al. 2004), they have traditionally maintained a collaborative relationship with public authorities (Trägårdh 2007). As a consequence, many CSOs are represented at different administrative levels (local, regional, and national) by umbrella organizations (Einarsson 2012). The recent decade's trend to privatize public services, such as education, welfare, health, and social care (Hartman 2011), has created new opportunities for civil society organizations to act as providers of services on behalf of public authorities and with public funding (Arvidson et al. 2017). These changes in the welfare system, together with a call by public authorities for increased collaboration with CSOs - not least for handling recent challenges linked to the integration of newly arrived immigrants - has further emphasized the CSOs' role as service providers.

The position of service provider does not, however, exclude CSOs from also pursuing political influence (Fyall 2017). As expressed in the agreement between the government and CSOs in 2008, in order to keep fulfilling the role of a critical voice, even when in collaboration with public authorities for service provision and when receiving public funding, CSOs should be able to maintain their independence (Arvidson et al. 2017). It means, for instance, that CSOs that receive public funding should not risk losing public support because of voicing criticism towards public policy or because of their advocacy activities for political and societal change based on their commitment to their specific mission and values (Arvidson et al. 2018). We hence find CSOs engaging in many policy areas, including the fields of migration and integration. In these specific policy areas, we find, among others, the following types of organizations: ethnic, 
solidarity, religious, sports, adult education, and human rights organizations (Jönsson \& Scaramuzzino 2018).

While the government invites certain organizations to provide comments on the draft proposals, the referral process is in fact open to anyone who wants to comment. Among the organizations that are invited to comment on such proposals we find public organizations, private enterprises, and CSOs. For the latter, this is a crucial channel for political influence besides other advocacy strategies, such as lobbying, demonstrations, petitions, and statements in traditional media or social media (Scaramuzzino \& Scaramuzzino 2017). To be a 'referral-instance,' i.e. to be invited by the government to comment on legislative drafts can be seen not only as a token of status, as a legitimate representative for certain interests, but also of an embeddedness in the system (Hedling \& Meeuwisse 2019).

The importance of this arrangement has been questioned in the contemporary political process as other forms of interest representation, such as lobbying, seem to have increased in importance (Naurin 2001; Lundberg 2014). Some research shows that the number of CSOs submitting comments within the referral system has declined (Lundberg 2014). The referral system is however still widely used by organizations for expressing their claims in relation to decision making in the legislative process (Johansson et al. 2019). It is often praised for being formal, structured, transparent, and open, also in the sense of having a low threshold for participation. Its effectiveness in achieving actual political influence has been questioned and it has been suggested that its benefit is not only to be understood in a broader perspective as legitimizing the organizations, but also getting the attention of the media and decision-makers and for the internal communication within civil society (Lundberg 2014). Hence, we expect the organizations to make use of the system to make claims in relation to public policy (in terms of new legislation), based on the mission and values that guide their activity.

\section{Civil society organizations' activities and values pertaining to migration and integration}

Here follows a short presentation of the five organizations that have been selected for our study; the Swedish Christian Council, the Swedish Red Cross, Save the Children, the umbrella organization for ethnic organizations SIOS, and the Swedish Women's Lobby. The presentation includes relevant activities in the field of migration and integration, as well as a focus on their normative commitments as expressed in their mission statements (self-description).

The Swedish Christian Council (SKR) is an umbrella organization for all Christian denominations in Sweden. The board consists of representatives of the four Christian 'families': the Lutheran (Church of Sweden), Catholic, Orthodox denominations, and the 'Free Churches' (mostly Lutheran faiths not affiliated to the former state Church). In a document ratified by the board in 2016, the Christian Council clarifies its commitments and values in the field of migration and integration. The document makes explicit the centrality of 
the experience of refuge and exile for the Christian faith. Also, the central values of grace and charity, the special consideration of 'the poor, the powerless, and the discriminated,' and the value of the 'inclusion of the stranger' (SKR 2016: 6) are derived from this overarching experience of displacement. As a result of these overarching values, the SKR formulated the following normative guidelines for its stance on migration: the right to a life in dignity, fundamental rights for all human beings, special consideration for children and their situation, the right to family life (in one place), everybody's obligation to contribute to a positive societal development, and the goals of peace, justice, and sustainability (SKR 2016: 15). The Lutheran Church (Church of Sweden) is the biggest denomination within the Council, and with six million members it is also the biggest civil society organization in Sweden. In the field of immigrant integration, many of its congregations offer various regular activities, such as language cafés. However, they are also engaged in various humanitarian activities, according to local needs. Activities in the field of migration and integration also include lobbying for a humane migration and integration policy.

The Swedish Red Cross is, just as its mother organization the international Red Cross, an international solidarity organization. The general scope of its activities is to help people in need, above all, in case of catastrophes due to war or natural disaster. In Sweden, the activities are arranged locally and can differ between various local or regional sections. As an example, the section in the southern city of Malmö identifies the challenges for many of the city's inhabitants to be poverty, loneliness, and a feeling of alienation from society. Therefore, the prioritized areas of activity are migration and integration, health, and social participation. In the field of migration, the section offers 11 different activities, among others, meeting places, language training, and home-work support for children and young people (Svenska röda korset Malmö 2019). Before 2015, the activities included help with homework for young people, meeting places, and psychological support. During the summer and autumn of 2015, the Malmö Red Cross was involved in many emergency activities and outreach work at the Malmö train station. Activities after 2015 have mainly focused on creating meeting places and providing civil orientation and language training, depending on the participants' needs. The organization is involved in a lot of collaborations with other civil society actors, for example, ones working for homeless or unaccompanied minors. The most relevant values that the Red Cross bases its missions and self-image upon is impartiality (working solely to reduce human suffering and to help those most in need), and neutrality (expressing no opinion regarding politics, ethnic belonging, religion or ideology).

The umbrella organization for ethnic associations SIOS is a nation-wide umbrella organization consisting of ca. 350 local ethnic organizations with ca. 50,000 members in total. It is recognized (i.e. partially funded) by the 
government for its promotion of ethnic and cultural identity, representation of ethnic groups' interests, and promotion of their participation in society. Independent of party politics and religion, the organization promotes voluntary collaboration between various ethnic associations for the purpose of working for cultural diversity in society in a democratic manner. Its main purpose is to promote language, culture, education, and other issues related to minority politics. SIOS' activities aimed at achieving these goals include opinion making, writing position papers, and making claims through statements, as well as through educational, information, and project activities (SIOS 2017). In the area of integration, SIOS holds an active role in influencing policy. The organization does this through lobbying and other means of participation in the political process (such as consultation). Its vision of integration is based on a two-way process with ethnic organizations as equal partners. As such, it is against assimilationism. SIOS advocates for an open, democratic, and culturally diverse society that recognizes ethnic and cultural diversity (SIOS 2017). Its vision spells out the values of dialogue, equality, freedom of choice, and justice as guiding principles in this process (SIOS 2019).

The Swedish Women's Lobby (Svenska kvinnolobby) is an umbrella organization of the women's movement. It consists of 47 member associations throughout Sweden and it constitutes the Swedish section of the European women's lobby (EWL) with over 2,000 member associations. The organization works for women's enjoyment of their full human rights, and runs activities aimed at mainstreaming a women's and gender equality perspective in all political, economic, and social contexts, locally, nationally, on the European level and internationally (Sveriges kvinnolobby 2019). The organization's involvement in the field of integration and migration is mainly indirect, through the legislative consultation process, lobbying, and opinion shaping. The Women's Lobby compiles shadow reports on the implementation of the Convention on the Elimination of Discrimination against Women (CEDAW) to the government and the CEDAW committee in Geneva monitoring the implementation of the convention, highlighting women's specific situation in migration and integration, for instance with regards to Article 9 on citizenship. In their 2016 report, the Swedish Women's Lobby depicted that more women than men arrive through family reunification and point at the consequences for women when family reunification is subject to conditions of income. They pushed forward a demand for higher numbers of women in resettlement quota. Further demands were the improvement of foreign-born women's health, access to political representative positions, access to the labor market and work, and equal economic and social rights (Sveriges kvinnolobby 2016a). The organization's basic values are stated as gender equality and equality, based on the international Convention on the Elimination of Discrimination against Women (CEDAW) as well as the Beijing Action Plan (1995).

Save the Children (Rädda barnen) is a politically and religiously independent, democratic movement for Children's rights. Its role in the field of migration and integration is mostly in advocacy, that is, in opinion-building and 
influencing policy makers (e.g., through the legislative consultation process). However, the organization also supports children in difficult situations, both materially, and psychologically (Rädda barnen 2017). The organization is present in the refugee reception system, and as such, in asylum accommodations over the whole country, working for the prioritization of children's rights. The goal is to provide volunteer support for newly arrived children from the first day of arrival in Sweden; for example, through arranging child-friendly rooms at the reception centers and places of accommodation. They also conduct inspections of asylum accommodations, arrange language and homework help, organize leisure time activities, as well as discussion groups, and meeting places. The organization also offers education in 'trauma conscious care' for more than 8,000 people working in 230 municipalities to increase the knowledge of the personnel working with reception. They also organize direct support for children, youth, and parents through a direct telephone line in several languages (Rädda barnen 2019a), work for children in vulnerable situations in Sweden, in general, and towards equal conditions for all children throughout the country (Rädda barnen 2019b). Their most central values are embedded in the human rights perspective, particularly, the child's perspective and reality, and the child's rights. The principle of the child's best interest is the normative guideline. This value fundament builds on the UN Universal Declaration of Human Rights (1949) and the Convention on the Rights of the Child (1989). After having presented the organizations and their values, it is now time to turn to the policy processes considered in the analysis.

\section{The legislative consultation system}

In the policy field of immigration, for the period before 2015, we have selected a legislative draft concerning the introduction of financial and material requirements for family reunification (Regeringens proposition 2009/10: 77). Its basic premise is that the applicant is required to show the ability to financially and materially support the family members entering Sweden (through 'proper' accommodation). As one of the last EU countries, Sweden introduced its first pre-entry admission policy targeting family members in April 2010. The government's rationale with the policy was declared as 'improved integration,' both for the person already in Sweden as well as for the new family members. From a proponent's point of view, the policy proposition is seen as an incentive for employment and self-sufficiency. The policy's target group was a small group of people receiving subsidiary protection (Suter \& Qvist 2012).

For the period after 2015, the legislative draft concerning a temporary reduction of ways to get a residence permit in Sweden was selected. The proposal suggested a number of restrictions to obtain a residence permit in Sweden for a period of three years (June 2016-June 2019). The proposal contained suggestions to issue temporary residence permits to applicants in all categories of protection statuses as well as to severely limit family reunification, among others, by extending the financial and material requirements to more 
protection groups (except for resettled refugees). This policy measure effectively reduced Sweden's asylum policy to the EU minimum standard, and was seen as a very drastic measure (see also Bevelander \& Hellström 2019).

For the policy field of integration, for the period before 2015, we have studied normative expressions in the legislative consultation process on a major shift in integration policy, the so-called Establishment Reform [etableringsreformen]. The policy proposal constituted a major administrative reform that shifted the responsibility for the integration of newly arrived immigrants from municipalities to the state. Furthermore, it expressed very clearly the responsibility for integration (which is understood as becoming employable) to lie with the individual immigrant rather than with the receiving society.

For the period after 2015, we have selected a legislative draft containing a number of suggestions to reform the regulations of the establishment system (not the system itself), aiming at facilitating and quickening the integration process of newly arrived immigrants (i.e. those who received a residence permit) with regards to participation in the labor market and society. The main reason behind the legislation named was to simplify the administration of the system. However, the document also contains several references to the Employment Services' increased possibility for financial sanctions against individuals as well as an increased mandate to decide on an individual's activities (less so for newly arrived immigrants). It is noteworthy that no reference is made to the events of autumn 2015, nor to the high number of asylum seekers in the reception system.

The two most recent pieces of legislation (the legislative draft prop. 2015/ 16: 174 and Ds 2016: 35) can be seen the government's reaction to the increasing number of people seeking refuge in Sweden during 2015.

Table 11.1 Selected legislative drafts in the policy fields of migration and integration, before and after 2015

\begin{tabular}{|c|c|c|}
\hline & Migration & Integration \\
\hline Before 2015 & $\begin{array}{l}\text { Legislative draft (proposition) } \\
\text { 2009/10:77: Financial support } \\
\text { requirement as a condition for } \\
\text { family member immigration } \\
\text { (Försörjningskrav vid } \\
\text { anhöriginvandring) }\end{array}$ & $\begin{array}{l}\text { Legislative draft (proposition) } \\
\text { 2009/10:60: Newly arrived } \\
\text { immigrants' establishment on } \\
\text { the labor market - individual } \\
\text { responsibility with professional } \\
\text { help (Nyanlända invandrares } \\
\text { arbetsmarknadsetablering - egen- } \\
\text { ansvar med professionellt stöd) }\end{array}$ \\
\hline After 2015 & $\begin{array}{l}\text { Legislative draft (proposition) } \\
\text { 2015/16:174: Temporary restric- } \\
\text { tions of residence permits in } \\
\text { Sweden (Tillfälliga begränsningar } \\
\text { av möjligheten att fä uppehållstill- } \\
\text { stånd } i \text { Sverige) }\end{array}$ & $\begin{array}{l}\text { Department series (departe- } \\
\text { mentserie) 2016:35: A new } \\
\text { system of rules for newly } \\
\text { arrived immigrants' establish- } \\
\text { ment in work life and society } \\
\text { (Ett nytt regelverk för nyanlända } \\
\text { invandrares etablering } i \text { arbets- } \\
\text { och samhällslivet) }\end{array}$ \\
\hline
\end{tabular}


The two consultation processes in 2009 took place during the early years of the liberal-conservative coalition government in Sweden (2006-2014), and were initiated by the government (consisting of the Liberal, the Centre Party, the Moderate, and the Christian Democratic Party). The consultation processes in 2015/16, on the other hand, were initiated by the 'red-green' government, a coalition between the Social Democratic and the Green Party, with external support from the Left party (2014-2018). This coalition government remained in power after the 2018 election but with the support of the Liberal and Center Party. As stated above, all four legislative and administrative changes have starkly shaped the policy fields of migration and integration in the last decade. They are, therefore, highly suitable to explore Swedish CSOs values on these two matters and to answer questions of potential value transformations before and after the high number of refugee arrivals in 2015 .

\section{Values expressed through the legislative consultation system (2009-2016)}

The following section presents a brief analysis of commentaries by Swedish organizations to the four policy proposals divided according to the two policy areas. All quotes and references relate to the comments made by the organizations to the propositions considered in each section. This publicly available but unpublished material was retrieved upon request from the office of the Swedish Government.

\section{Policy field of migration}

The first consultation process within the migration policy area regards the introduction of financial requirements for family reunification (2009). More specifically, the applicant was to show that s/he could support the incoming family economically and provide them with 'decent' accommodation. The government's rationale for this proposal was to 'improve integration' (Regeringens proposition 2009/10: 77). Among our sample of organizations, four of them commented on this proposal: Save the Children, SIOS, the Swedish Red Cross, and the Swedish Christian Council (SKR). All four organizations expressed criticism towards the proposal, in particular towards the argument that it would create better conditions for integration. In the words of the Swedish Red Cross: "OOur experiences] point to the fact that family reunification is often a precondition for successful integration and rehabilitation. This experience is also shared by many municipal public servants working with introduction of newly arrived immigrants' (Svenska röda korset 2009a). All organizations also extend the criticism to the view that newly arrived immigrants, as a group, are to be blamed for their lack of integration, and they oppose their being depicted as lacking incitements for integration (mostly finding a job). To the contrary, all organizations argue that a successful integration requires relevant structural changes in Swedish society. SIOS offers the following statement: 
The condition of self-support is intended as an incitement for the individual to get a job and a place to live as soon as possible. Our experience shows that most of the newly arrived immigrants do not need any incitement. They are already motivated and want to contribute. Lack of incitement among individuals is not the problem. The problem lies in the structural conditions of Swedish society.

(SIOS 2009a)

Furthermore, all organizations focus on children as a particular group that will ultimately be penalized by the reform. They argue that, in the case where the condition of self-support for family reunification should be implemented, families with children should be exempted from the policy. Not surprisingly, Save the Children expresses the strongest criticism towards the idea:

A consequence of the condition of self-support may be that family members will be forced to live separated for many years, which is very serious from a children rights' perspective. Save the Children argues that the condition of self-support lacks a rights' perspective in which the family is recognized as the base unit in society, and where the equal value of all people is recognized.

(Rädda barnen 2009)

To sum up, the clearest value expressed by the organizations is that of the family as a unit that belongs together. Following from that, the family member's spatial proximity is seen as a prerequisite for successful integration (rather than the other way around). Furthermore, the organizations express a normative stance on integration that sees its fundamental drive in the structural conditions of a country, rather than in the newly arrived individuals. Splitting families as a 'motivation for integration' is, the organizations argue, the wrong way to go, as it is not lack of motivation that hinders migrants from integrating, but structural factors in Swedish society. In this sense, they place a societal rather than individual blame for the problems of integration.

The second consultation process within the migration policy area relates to the government's reaction to the so called 'refugee crisis' and a government proposal to limit the possibilities for migrants to obtain a residence permit in Sweden in 2016. Three organizations commented on the proposal: The Swedish Red Cross, the Christian Council, and Save the Children. All organizations were very critical of the proposal, and the language used in their comments shows a high level of indignation. As stated by the Red Cross: 'The proposal and the rhetoric around it carry a risk of strengthening prejudice and stigmatization' (Svenska röda korset 2015). They see it as '...the result of an all too fast and not thought through process, at a time when political courage, persistence and reflection are needed more than ever' (ibid.). They 
also find the description of the background supporting the proposal 'misleading.' They, in fact, challenge the assumption, which according to the organizations is expressed in the proposal, that a reduced flow of migrants would improve opportunities for newly arrived migrants to integrate.

We find a similar tone in the Christian Council's comment in which the organization makes reference to the basic values of Christian theology to point to the proposal's discrepancy with many of its fundamental principles, including hospitality. The commentary refers to Jesus' experience of being a refugee, to the 'essential values that we argue come from the gospel,' and the churches' duty to protest against injustices and work for a better society for all people' (SKR 2015). It also specifies their values as 'everybody's equal worth,' 'hospitality,' and 'human dignity' (ibid.). The strong criticism in the commentary refers to both the language in which the issue is raised (presenting refugees as the problem) and the restrictions in the Swedish migration policies that are proposed by the government.

Save the Children is also strongly critical. The organization emphasizes a lack of respect for the conditions stipulated in the Convention on the Rights of the Child, as well as a lack of analysis of the proposal's consequences for children seeking refuge in Sweden. Furthermore, the organization is opposed to the proposal as it makes a distinction between people who are granted a residence permit under the 1951 Refugee Convention and people under subsidiary protection clauses, calling it out as a form of discrimination.

To sum up, the values expressed, on the one hand, relate to, the provisions proposed in the draft, which the organizations consider to be in opposition to human rights and principles of solidarity. According to these principles, Sweden has a duty to protect people fleeing war by granting them refugee status. On the other hand, there is a strong criticism of representing refugees and migrants as 'the problem' in the proposal, as the organizations fear this will only strengthen stigmatization and prejudice in Swedish society, and hinder the fostering of their basic values: everybody's equal worth, hospitality, solidarity, and non-discrimination.

Concluding our analysis on the policy field of migration, with regard to our research inquiry, we see no general shift in the values and norms expressed by the organizations before and after the refugee crisis. What is noticeable is that in 2016 - in the aftermath of the refugee crisis - the critique expressed by the organizations seems to become more radical and reference to their values and norms more explicit. The critique expressed in the first consultation process mostly points at the potentially negative effects of the provision, while the second policy proposal sparked a critique by the organizations that denounced the very ethical implications of the provisions. In some of the statements, the good faith of the government is called into question, as is the proposal, which is labelled as 'misleading.' This might be due to the fact that the second proposal implies a much stronger renunciation of Sweden as a welcoming country towards refugees, compared to the first one. 
The policy field of integration

The first consultation process within the field of integration concerns the introduction of a new system for the integration of newly arrived immigrants, the Establishment Reform (Regeringens proposition 2009/10:60). Two of our selected organizations commented on the proposition, i.e. the Swedish Red Cross and SIOS. Both organizations have a positive view of this governmental initiative, in the sense that they see a need to reform the integration system. However, they are also critical of its focus on the individual immigrants' responsibilities and alleged shortcomings that they see implied in the proposition:

The Swedish Red Cross notes, however, that the draft in this way exclusively bases its statements on the obligations of the newly arrived immigrants and not of the receiving country, which might be interpreted as perceiving the problem to mostly lie with the newly arrived immigrants. However, it can, in our opinion, also lie in the knowledge, attitudes, and values among us Swedes.

(Svenska röda korset 2009b)

The organization goes even further in its criticism suggesting that the proposal includes 'generalizing and categorizing judgments about newly arrived immigrants' (ibid.). The organization states that it is against 'all forms of discrimination' (ibid.), implicitly arguing that these judgements might be interpreted as discriminatory. Both organizations welcome the proposal of a dialogue between the government and the CSOs working with integration, but they expect a more holistic view of the issue. In the words of SIOS: 'but we think it should be about more than the labor market and education issues. Participation in societal life is an important entry point into the labor market' (SIOS 2009b). To sum up, the organizations base their criticisms of the proposal on the idea that integration should concern more than labor market participation and should include other societal aspects. Furthermore, they emphasize the principle which was also evident in their comments concerning migration policy, namely, that the problems with integration, and hence the solution to them, do not lie within the migrant group, but rather, in the structures of Swedish society.

The last proposal concerns a modification of the integration system introduced in 2008, i.e. a new regulation for newly arrived immigrants' integration proposed in 2016. The comments submitted among our sample of organizations are from the Swedish Red Cross and Swedish Women's Lobby. Their approach to the proposal is quite different. While the Red Cross is generally positive towards the proposal in most of its aspects, the organization is critical of the context in which it is implemented. Here, they mostly relate to the government's migration policy of restricted access to residence permits: 
The Swedish Red Cross wants to highlight, in particular, the effect that limitations in opportunities for family reunification, time-limited residence permits, and the fact that many newly arrived immigrants suffer from mental illness have on the [immigrants'] preconditions for utilizing the provisions [offered within the system of integration, e.g., Swedish classes for immigrants].

(Svenska röda korset 2016)

The Swedish Women's Lobby's commentary highlights the lack of a genderperspective in the current integration system. The criticism is strong in both language and the content, as expressed in the following quote claiming that the integration system is very unequal gender-wise: 'the [gender] inequality within the integration system is striking' (Sveriges kvinnolobby 2016b). This is due to the lack of an active gender-based provision and, hence, a critique of a 'gender-blindness' in the system. The authors of the commentary in fact stress that gender equality 'does not come by itself. In order to allow women to use the [integration] provisions ${ }^{2}$ to a higher degree, active gender-equality work is required' (ibid.). Another more general criticism is that, in their opinion, it seems that it is not the needs of the newly arrived immigrants that are at the base of the reform, but rather the public authorities' need for effectiveness and cutting costs. To sum up, the organizations have expressed criticism towards the proposal, but the values and norms behind it are not very explicit. The criticism is more about what the proposal does not address (restrictive migration policy and gender-blindness), than about the actual provisions that are proposed.

In conclusion, in this section on integration policy, our analysis does not show any general shift in the values and norms expressed by the organizations before and after the refugee crisis in the field of integration policy. It is noticeable, however, that the organizations have extended weaker criticism to the latter proposal than to the first one. This is likely due to the fact that the second proposal implies a less radical change from the system at the time than the first one. In fact, until 2009, the Swedish integration policy had emphasized multiculturalism, the fight against structural discrimination, and the psycho-social dimensions of integration (Scaramuzzino 2012). It could further be interpreted as the organizations' acceptance of the government's shift in perspective from structures to individuals, which they had criticized in 2009, and as a result of which, their criticism focuses on the implementation of the integration policy rather than its underlying values.

\section{Concluding discussion}

It is clear from this brief analysis of commentaries by Swedish organizations that the Swedish referral system offers an arena for engaging in value-based advocacy. It allows us to see 'values in action.' In fact, the organizations 
clearly use this arena as a space for articulating policy-related claims that are based on their norms and values. As we can see, they share a common base of values in the policy fields of migration and integration focusing on humanitarianism, hospitality, inclusion, and solidarity towards the migrants coming to Sweden. Further, they also share an understanding of the structural nature of inequality, underlining their conviction that most causes of the problems with integration are to be found in the Swedish society rather than in the individuals migrating to Sweden. This is emphasized by many organizations in the different consultation processes analyzed here. Hence, they strongly criticize the government's attempt to justify policy changes that have a negative impact on migrants. Illustratively, they challenge the government's claim that restricted immigration is necessary for sustaining the general welfare system. They further oppose the government in its claim that poor integration results are the result of the individual migrants' lack of motivation or skills.

The statements in which values are most discernible concern the drastic changes in the migration policy of 2016. While the policy change in 2009 introducing requirements for family reunification received strong criticism based on the apprehended negative consequences of the provision for migrants, the commentaries on the 2016 proposal signal a complete clash between the government's position and the values and norms that the organizations stand for. The criticism of the 2016 legislative draft has been so strong that we also find a spill-over into the field of integration policy; for instance, the Red Cross' argument that the restrictions on the possibilities to obtain a residence permit are not only a violation of human rights, but also an obstacle to successful integration of those migrants that manage to enter the country.

In the integration policy area, the criticism is significantly weaker, and the values are less explicitly expressed. The criticism is mostly based on the allegedly negative effects of the proposed provisions on the integration of newly arrived refugees, rather than on the values and norms implied. We see, however, that the organizations have expressed the need for a more structural perspective on integration. This was particularly visible in the consultation process of the Establishment Reform of 2009, and may be explained by the fact that it implied a strong shift away from the traditional, more structure-focused integration policy. The 2006-elected liberal-conservative government introduced 'individual responsibility' as a bearing concept, something the organizations reacted to by stressing the need to tackle structural problems, such as discrimination and socio-economic inequality, instead. It is interesting to notice that this criticism does not appear in the comments from 2016, except for when it comes to structural issues of gender inequality. It is also interesting to notice that the more critical the organizations are of a legislative draft, the more explicitly they ground their comments in their value-bases and ideology, for instance in Christian theology or human rights. 


\section{Notes}

1 All translations into English are the authors.

2 Integration provisions of language course and other educational activities.

\section{References}

Anheier, H. (2005). Nonprofit Organizations: Theory, Management, Policy. Oxon/New York: Routledge.

Arvidson, M., Johansson, H., \& Scaramuzzino, R. (2017). 'Advocacy Compromised: How Financial, Organizational and Institutional Factors Shape Advocacy Strategies of Civil Society Organizations,' VOLUNTAS: International Journal of Voluntary and Nonprofit Organizations, 29(4), pp. 844-856.

Arvidson, M., Johansson, H., Meeuwisse, A., \& Scaramuzzino, R. (2018). 'A Swedish culture of advocacy? - Civil society organizations' strategies for political influence,' Sociologisk Forskning (2-3), pp. 341-364.

Beck, J. C. (2013). 'Ideology,' in Snow, D. A., Della Porta, D., Klandermans, B., \& McAdam, D. (eds) The Wiley-Blackwell Encyclopedia of Social and Political Movements. Chichester: Wiley-Blackwell.

Bevelander, P. \& Hellström, A. (2019). 'Citizens to Stay. Pro - and Anti-migrant Mobilizations in Polarized Sweden,' in Rea, A., Martiniello, M., Mazzola, A., De Cuyper, P., \& Meuleman, B. (eds), The Refugee Reception Crisis in Anti-Immigrant Times. Polarization of the Public Opinion, Local Mobilizations and Reception Practices in Europe. Brussels: ULB Press - European Studies.

Brekke, J. P. \& Borchgrevink, T. (2007). Talking About Integration: Discourses, Alliances and Theories on Labour Market Integration in Sweden. Oslo: Institutt for samfunnsforskning. Rapport - Institutt for samfunnsforskning.

Department Series (Ds) (2016) 35. Ett nytt regelverk för nyanlända invandrares etablering $i$ arbets - och samhällslivet. Stockholm: Department of Labour Market, 18 Oct 2016.

Einarsson, T. (2012). Membership and Organizational Governance (Doctoral dissertation). Stockholm: Handelshögskolan.

Emilsson, H. (2018). 'Continuity or Change? The refugee crisis and the end of Swedish exceptionalism,' MIM Working paper Series no. 3, Malmö University.

European Migration Network (2016). Country Fact Sheet Sweden. European Migration Network. Available at: www.emnsweden.se/download/18.5bc6881815e14db6750733/ 1504092553617/EMN_Sweden_country_factsheet_2016_en.pdf

Feltenius, D. (2008). 'From outsiders to influential insiders: Pensioners' organizations in the policy process in Sweden,' Journal of Comparative Policy Analysis: Research and Practice 10, pp. 29-46.

Fyall, R. (2017). 'Nonprofits as advocates and providers: A conceptual framework,' Policy Studies Journal45(1), pp. 121-143.

Hartman, L. (ed.) (2011). Konkurrensens konsekvenser - Vad händer med svensk välfärd? Stockholm: SNS.

Hedling, E. \& Meeuwisse, A. (2019). 'Access to the European Union and the role of domestic embeddedness,' in Meeuwisse, A., \& Scaramuzzino, R. (eds), Europeanization in Sweden: Opportunities and Challenges for Civil Society Organizations. New York: Berghahn Books.

Johansson, H., Kassman, A., \& Scaramuzzino, R. (2011). Staten och det civila samhällets organisationer $i$ ett föränderligt välfärdssamhälle. Stockholm: Överenskommelsen. 
Johansson, H., Scaramuzzino, R. \& Wennerhag, M. (2019). 'Social movements and interest groups compared. How organisational type matters for explaining Swedish organisations' advocacy strategies,' PArtecipazione e COnflitto.

Jönsson, A. \& Scaramuzzino, R. (2018). Föreningsaktiviteters betydelse och mervärde för nyanländas etablering genom NAD. Socialhögskolan, Lunds Universitet.

Linde, S. \& Scaramuzzino, R. (2018). 'Is the Church of Sweden an 'ordinary' civil society organization? - The advocacy activities of the Church in comparison to other civil society organizations in Sweden,' Nordic Journal of Religion and Society 31(2), pp. 118-138.

Lundberg, E. (2014). 'Intresseorganisationernas deltagande i politiska beslutsprocesser,' Rapport på uppdrag av Demokratiutredningen.

Lundström, T. \& Wijkström, F. (1997). The Nonprofit Sector in Sweden. Manchester: Manchester University Press.

Lönnaeus, O. (2015). 'Löfvén: Svårt att regera utan DÖ,' Sydsvenskan, 29 April. Available at: www.sydsvenskan.se/2015-04-29/lofven-svart-att-regera-utan-do

Micheletti, M. (1995). Civil Society and State Relations in Sweden. Aldershot: Avebury.

Migrationsverket (2019). Beviljade uppehållstillstånd 2009-2018. Available at: www. migrationsverket.se/Om-Migrationsverket/Statistik/Beviljade-uppehallstillstand-o versikter.html

Naurin, D. (2001). Den demokratiske lobbyisten. Boréa: Umeå.

Rädda barnen (2009). Svar på remiss prop. 2009/10:77. Swedish government office.

Rädda barnen (2017). En bättre värld för barnen. Årsrapport 2017. Available at: www. raddabarnen.se/globalassets/dokument/om-oss/arsredovisningar/radda_barnens_a rsrapport_2017.pdf

Rädda barnen (2019a). Vi ger barn som flytt till Sverige en bra start $i$ sitt nya land. Available at: www.raddabarnen.se/vad-vi-gor/barn-i-sverige/ger-nyanlanda-barn-en-bra-start/

Rädda barnen (2019b). Barn i Sverige ska växa upp på lika villkor. Available at: www.ra ddabarnen.se/vad-vi-gor/barn-i-sverige/bekampar-utanforskap/

Regeringen (2015a). Tal av statsminister Stefan Löfvén vid manifestationen för flyktingar. Stockholm, September 6. Available at: www.regeringen.se/tal/2015/09/tal-av-stefa n-lofven-vid-manifestationen-for-flyktingar-den-5-september/

Regeringen (2015b). Regeringen föreslår åtgärder för att skapa andrum för svenskt flyktingmottagande. Stockholm, November 24. Available at: www.regeringen.se/artiklar/2015/ 11/regeringen-foreslar-atgarder-for-att-skapa-andrum-for-svenskt-flyktingmottagande/.

Regeringens proposition 2009/10:60. Nyanlända invandrares arbetsmarknadsetablering egenansvar med professionellt stöd. Department of Integration and Gender Equality, November 17.

Regeringens proposition 2009/10:77. Financial support requirement as a condition for family member immigration. Stockholm, Department of Justice, December 21.

Regeringens proposition 2015/16:174. Tillfälliga begränsningar av möjligheten att få uppehållstillstånd i Sverige. Stockholm, Department of Justice Stockholm, April 28.

Salamon, M. L., Sokolowski, S. W., \& List, R. (2004). 'Global civil society - An overview,' in Salamon, L. M. (ed) Global Civil Society - Dimensions of the Nonprofit Sector. Bloomfield, CT: Kumarian.

Scaramuzzino, G. \& Scaramuzzino, R. (2017). 'The weapon of the weak? - Swedish civil society organisations' use of social media to influence politics,' Journal of Information Technology $\mathcal{E}$ Politics, 14(1), pp. 46-61.

Scaramuzzino, R. (2012). Equal Opportunities? - A Cross-National Comparison of Immigrant Organisations in Sweden and Italy. Malmö: Malmö University. 
Scaramuzzino, R. \& Wennerhag, M. (2019). 'Europeanization of Swedish civil society: motives, activities, and perceived consequences,' in Meeuwisse, A \& Scaramuzzino, R. (eds), Europeanization in Sweden - Opportunities and Challenges for Civil Society Organizations. New York: Berghahn Books.

SIOS (2009a). Svar på remiss prop. 2009/10:77. Swedish government offices.

SIOS (2009b). Svar på remiss Prop. 2009/10:60. Swedish government offices.

SIOS (2017). Verksamhetsberättelse 2017. Available at: http://sios.se/wp-content/uploa ds/2019/02/sios_vb_2017_sammanfattning_och_detaljerad.pdf

SIOS (2019). Idéprogram. Available at: http://sios.se/om-oss/

SKR (2015). Svar på remiss Prop. 2015/16:174. Swedish government offices.

SKR (2016). 'Detta vill vi! Kyrkorna och migrationsfrågorna,' Sveriges kristna råd skriftserie 22. Available at: www.skr.org/wp-content/uploads/2018/10/SKR_Skrift_ 22_Detta-vill-vi.pdf

Suter, B. \& Qvist, M. (2012). 'Study on the national frame for the integration of newcomers-Sweden,' PROSINT Country Report. Vienna: International Centre for Migration Policy Development (ICMPD).

Svenska rödakorset (2009a). Svar på remiss Prop. 2009/10:77. Swedish government offices.

Svenska rödakorset (2009b). Svar på remiss Prop. 2009/10:60. Swedish government offices.

Svenska rödakorset (2015). Svar på remiss Prop. 2015/16:174. Swedish government offices.

Svenska rödakorset (2016). Svar på remiss DS 2016:35. Swedish government offices.

Svenska rödakorsetMalmö (2019). Våra verksamheter. Available at: https://kommun. redcross.se/malmo/vart-arbete/.

Sveriges kvinnolobby (2016a). Living Up to CEDAW - What Does Sweden Need to Do? The Swedish CEDAW Network's Shadow Report to the Swedish Government's Eighth and Ninth Periodic Reports on the Implementation of the CEDAW Convention. Available at: http://sverigeskvinnolobby.se/wp-content/uploads/2016/01/ Skuggrapport-CEDA W-Engelska.pdf

Sveriges kvinnolobby (2016b). Svar på remiss DS 2016:35. Swedish government offices.

Sveriges kvinnolobby (2019). Om organisationen. Available at: http://sverigeskvinnolobby. se/om-sveriges-kvinnolobby/om-organizationen

Swedish government offices (2009). Svara på remiss- hur och varför. Om remisser av betänkande. SB PM 2003:2.

Trägårdh, L. (2007). 'Introduction,' in Trägårdh, L. (ed.) State and Civil Society in Northern Europe: The Swedish Model Reconsidered. New York and Oxford: Berghahn Books.

Turunen, J. \& Weinryb, N. (2017). 'Volontärer i välfärdsstaten: socialt arbete med transitflyktingar som politisk handling,' in Linde, S. \& Scaramuzzino, R. (eds) Socialt arbete i civilsamhället: aktörer, former och strukturer. Lund: Studentlitteratur. 


\title{
12 Community-based sponsorship of refugees resettling in the UK
}

\author{
British values in action?
}

\author{
Joanne van Selm
}

\section{Introduction}

The United Kingdom has a centuries long history of welcoming refugees and migrants to its shores. While there is, and always has been, some degree of citizen opposition or reluctance towards the arrival of newcomers, the UK also has a wide base of civil support for newcomers. This has sometimes been vocal, for example, in the case of Kosovars in 1999, when, as in other EU Member States, outspoken popular support for the displaced population prompted governments to instigate a Humanitarian Evacuation Program, for the organized movement, and temporary protection, of over 54,000 people, of whom 4,346 were welcomed to the UK (Guild 2000: 67). The baseline norms and values on which UK immigration and asylum law and policy are based are, in essence, humanitarian but they are also contested.

Encapsulating 'British values' and applying them to the migration field is a significant challenge. It probably always was so, but in 2019, as Brexit hangs in the balance and British politics seems to spiral out of control, it is even more challenging. Part of the confusion or complexity is in the very essence of what it means to be 'British.' Add to that the muddle of what exactly are 'British values' and then how these are expressed in relation to immigration and refugee protection and the complexities are compounded. Yet, at the heart of any discussion about 'values,' it could be said, there is a point to be made about compassion and tolerance - about tolerating and being tolerated.

While passions rage about immigrants and the lack of integration, a relatively small, but growing, group of British citizens is putting compassion and tolerance into practice through their support and sponsorship of refugee resettlement. Conceptually, this practice of sponsorship of these newcomers could be seen as an island of calm amidst very troubled waters: the refugees being selected, who have fled the conflict in Syria, are avoiding the dangerous sea crossings being undertaken by asylum seekers in the Mediterranean and participating in an exemplary scheme of orderly arrivals. The sponsors stand out from the crowd of anti-immigrant voices, as they have pushed for, and now put into practice, the ability to support refugees in their gradual 
finding of their place in British society. Whether or not we can really establish agreement about what 'British values' are, tolerance is fundamental to any society in which there are differences - and there is no society without differences.

The core questions for this chapter will be: how can we conceptualize participation in community sponsorship efforts from a values perspective? How could sponsorship of refugees by a few spread those values to, or strengthen those values in others in society? How can tolerance be understood, and developed, in a country where immigration has happened more quickly than its core citizenry has managed to adapt to it?

The chapter will first draw the broad outlines of the discussion of, and what can be understood by, 'British values.' By way of background, it will then turn to the re-emergence of resettlement as an avenue to protect refugees in the UK, and how the community sponsorship program came about, as a response to requests by some civil society organizations. The community sponsorship scheme aims at facilitating the integration, through various support mechanisms, of some of these refugees. Based on secondary research, the Community Sponsorship Program and its implementation will then be described. Evaluations of the program conducted to date will be drawn on to examine specifically how it is faring as an expression of British values, both through the integration of refugees, and through the avenue it presents to sponsors to strongly uphold the value of tolerance, while intolerance seems to hold sway in parts of the population around them. The program, and its place in the British value system, will then be analyzed from the perspective of toleration, based on the essays of that name by Michael Walzer (1997) including the expansion of toleration and its limits. This chapter is primarily a 'think piece,' consisting of desk research and the pondering of the somewhat theoretical extent of toleration in a constantly evolving community and society.

\section{What are British values?}

In the first two decades of the twenty-first century, faced with domestic and international terrorism and extremism, the UK has set about searching for a national identity. The coalition Conservative-Liberal Democrat government in power from 2010 to 2015 determined a set of British values, in the context of the prevention of extremism, and decided that these should be taught in schools and implemented in various public settings. This decision to define 'British values' came after centuries of essential muddle, in which what it meant to be 'British' or to hold 'British values' was not defined, but was fairly clear to everyone in an unspoken way (Richardson 2015). Having drafted a set of 'British values' and started trying to spread them, the government and population find that they are intrinsically contested, and may not be making the situation any better or clearer. In relation to immigration and refugee protection this becomes even more the case, as terms such 
as 'humanitarian' and 'tolerant' are used, but not always lived up to in the eyes of many - or overdone in the eyes of others (see Jarvis, Atakav, \& Mardsen 2017).

The 'values' debate in the UK is extremely complex at this point in time, not least because both the 'values' and their representation as 'British' are entwined in the near even split in the country over not only EU membership, but what Britain, as part of broader Europe, means: Britain in the EU is more clearly outward looking, accepting of diversity and tolerant. Britain leaving the EU is less tolerant, less accepting of diversity, inward looking, and may ultimately fully devolve into a disunited former kingdom.

As such, it is difficult, perhaps impossible, to point to facts on what British 'values' are: people on different sides can say they hold the same things to be their guiding norms, yet mean something completely different from each other.

The British anti-immigration nationalists claim to wish to protect a proud country, that stands tall, alone as a strong nation. Indeed, a Google search of 'Nigel Farage British Values' brings a stream of two types of articles to the fore. The first are interviews and supporters' opinion pieces in which the Brexit/ex-UKIP leader is cited as the champion of 'British values' who will protect the Judeo-Christian culture, national identity, and allow people to 'be British' again. The second category are an equal number of commentary articles strongly asserting that Farage/UKIP/Brexit Party stand for the precise opposite of real British values and above all are stoking racism and intolerance. Describing, very soon after the 2016 referendum, how the notion of British values has been discredited and become muddled, Yates points out that:

While incidents of racism are on the rise, perhaps it is the insidious racism normalized through political rhetoric that has ignited racist attitudes to boiling point. The seemingly single narrative of the Leave campaign was effective because it aligned with attitudes that politicians across Labor, Conservative, and UKIP have been rolling out since last year: that the so-called 'British Values' - of liberty, independence and strength - have been squashed by new immigrant populations who have muddied the waters of British Values. The referendum result provided the catalyst for attitudes towards immigrants to come to a head.

(Yates 2016)

This focus on what is meant by British Values has, as noted, been a major topic for the British government, sparked by discussion arising from acts of Islamic terrorism in the UK, starting with the July 2007 attacks in London. The coalition government of 2010-2015 sought (perhaps understandably in the political climate, but perhaps also leaving margins for misinterpretation and misunderstandings) to deepen the sense of values through teaching in school as well as the approach to national security. 
The UK government's Office for Standards in Education, Children's Services and Skills (Ofsted) requires that British values be taught in schools across the country. These values are: democracy, the rule of law, individual liberty, and mutual respect for and tolerance of those with different faiths and beliefs and for those without faith.

This list of British values is taken by Ofsted from the 2011 UK Home Office report Prevent Strategy designed to update the government's approach to terrorism and extremism (UK Government 2011). While this is the definition of British values included in the report's Glossary, elsewhere the report refers to British values as: 'democracy, rule of law, equality of opportunity, freedom of speech and the rights of all men and women to live free from persecution of any kind' (UK Government 2011: 44). In other words, even the original governmental source on the defining of 'British values' gives at least two definitions.

Some parts, and sometimes large parts, of the UK population have serious reservations about a multi-cultural and really diverse approach to those arriving and their integration. This is not new. Opposition to immigration was notoriously espoused by Enoch Powell, with his Rivers of Blood speech in 1968. The immigration of that time was primarily from the Commonwealth, and the grounds for opposing it were above all racial. The British nationalists of the late 2010s, emboldened by the 2016 referendum outcome for the UK to leave the European Union, 60 years on from Powell's (deliberately) inflammatory vision, indicate they would return to a focus on the Commonwealth, not for immigration necessarily, but for trade and international alliances, and oppose both European and non-Christian, in particular Muslim, immigration. A 2018 British Futures report looking at the 50 years since Powell's speech addressed the evolving nature of British society's position on immigration, race and diversity, showing how Powell was wrong, and that Britain has largely avoided the racial strife foretold, although the country faces continued, if different, challenges on the immigration and integration front (Ballinger 2018).

Nonetheless, the value those opposing immigration apparently contest is that of equality and of 'mutual respect for and tolerance of those with different faiths and beliefs and for those without faith.' This is crucial to a consideration of British norms and values in relation to immigration and migrants today. While the drafting of this 'value' might have come about in the context of, essentially, explaining to immigrants what they are expected to do to integrate in and be part of British community, the problem it exposes is that a large part of the British community has limited or no tolerance for people with different faiths and beliefs, particularly if their faith is (or is thought to be) Islam.

The think tank British Future together with the group HOPE not hate conducted a National Conversation on Immigration involving 60 meetings across the UK as well as online surveys culminating in a June 2018 final report (Rutter et al. 2018). It found that 75 percent of both UK born and 
non- $\mathrm{UK}$ born respondents saw integration as showing respect for British traditions and values (p. 123), and that those responding were roughly equally split on the question of whether or not migrants integrate in their local communities (p. 125). Indeed, people who had migrated to the UK in the 1950 s, for example, suggested that their approach to integration at that time was significantly different from that of today's newcomers (p. 213): it is not clear, as the context that inspired Powell's 1968 speech shows, that British citizens of the day agreed. A minority of respondents to the National Conversation on Immigration saw the responsibility for adaption as being only on the shoulders of the immigrants, with a majority seeing a question of respect for shared values being a responsibility of all involved, including government as well as the broader population (p. 129). Shared values as a basis for integration were perceived as the third most significant factor, slightly behind newcomers learning English and contributing through taxes and employment to British economy and society (p. 130). At the same time, respect for refugee protection was viewed as being intrinsic to British values (p. 153).

There are two primary groups of immigrants who face intolerance in the UK in 2019: Europeans who have migrated under freedom of movement regulations of the EU and people who are, or sometimes are presumed to be although they are not, Muslims. These two 'groups' (although neither is homogeneous) are vastly different both in the resources they bring to their movement, and the options they have, as well as in what their 'integration' means. The EU citizens generally have more resources, if not always necessarily in monetary terms then in services they can access. They have many more options, not least because they can choose to live in another 27 different countries, without legal impediment, although they may have made their family, economic, and cultural life in the UK for many years. Their integration is also different in that they are equal EU citizens, and have been in every way until the challenges and unforeseen barriers thrown up by the impending and unresolved issues of Brexit emerged.

The main target of the right in opposing Muslim (or thought to be Muslim) entry, protection, and integration are refugees, particularly from the Middle East, although also from Afghanistan and countries in Africa. Syrians, and other Arab and/or Muslim citizens displaced by the conflict in Syria constitute a major proportion of this group. These refugees generally have fewer resources available to them, from financial and language, to the presence of or ease in visiting family, for example. Starting a new life, often leaving the remnants of their former selves behind in refugee camps, the integration of these refugees can naturally be expected to be a challenge. That is the case even in a society that has invited the refugees in through a resettlement program.

The increasingly vocal, populist and extremist opinions which have entered the mainstream of British politics and public life have been emboldened by the outcome of the June 2016 Brexit referendum, and relative success of nationalist parties as well as the more right-leaning part of the 
governing Conservative party. There is, of course, statistically not a great margin of difference between the 52 percent for leaving the EU and the 48 percent for remaining in it, and another referendum could well return a quite different result. This close political division is reflected in the approach to immigration: some opinion surveys suggest that the UK population is fairly evenly split between people who wish to see current levels of immigration maintained or increased, and those who want some level of cuts in immigration numbers (Blinder and Richards 2018). While these latter voices frequently suggest that immigration challenges British values as refugees and immigrants sometimes find it difficult to integrate for various reasons, it can also be reasonably argued that those opposing immigration and establishing barriers to integration are themselves an affront to British values, and in particular that of tolerance. In other words, the challenge to British values comes not necessarily from newcomers, but from those in British society who reject refugees and those of 'other' or 'no' faith, of other ethnicity, of other nationality, and of other world view.

While some vocal elements across British society and the political realm speak about their British values and against those of other faiths (specifically Muslim), other parts of civil society in the UK are quite quietly, but strongly, supporting diversity, freedom from persecution and fear, and assisting newly arrived refugees very directly. In so doing, they are also supporting the British government in putting into practice the values for which it says it stands, even as some politicians of the governing Conservative Party seem to undermine those values in parliamentary and public debate. Civil society organizations sponsoring refugees fleeing conflict in Syria and arriving on the UK's resettlement program support not only the newcomers but also, it could be argued, the very essence of British values.

\section{Background: revival of resettlement and establishing sponsorship}

The vast majority of refugees arriving in the UK, as in most of Europe, at least since the 1970 s, enter the country requesting asylum or request asylum as an extension of their (regular or irregular) stay. In the past 15 years, European countries have looked more closely at alternative, and particularly organized, means of arrival for refugees. Primary amongst these has been resettlement - one of the three durable solutions for refugees, involving selection in a country of first asylum, preparation for and actual travel, arrival, with legal immigration status and integration support. Other more recent methods of such organized arrival programs include various Complementary Pathways, such as Humanitarian Admission Programs, Private Sponsorship, student visas and scholarships and labor mobility programs (ERN+ 2017; ERN+ 2018).

At the time of the 1999 Kosovar Humanitarian Evacuation Program mentioned above, the UK had only an extremely limited resettlement program, 
for just ten refugees requiring medical treatment each year. Organizing the arrival of 4,346 Kosovar gave a taste of how a larger resettlement program could work, even if they were being evacuated for temporary protection in that specific context. In 2004, the UK embarked on a broader resettlement program, The Gateway Protection Program, with a quota of around 750 arrivals per year (UK Government 2016a). The Gateway Protection Program has remained at a consistent level in its fifteen years of operation to the time of writing and welcomed refugees from a range of countries, offering them support in their arrival in the UK and their endeavors to integrate (e.g.; Collyer et al. 2019). In addition, the UK created two programs specifically for the resettlement of Syrians. The Vulnerable Persons Resettlement Scheme (VPRS), initially announced in 2014 as a plan to resettle several hundred Syrians over three years, but re-launched in September 2015 to accept 20,000 Syrians, and altered again in 2017 to accept refugees who have fled conflict in Syria but do not necessarily have Syrian nationality (UK Government 2017). The Vulnerable Children's Resettlement Scheme (VCRS) announced in 2016 was intended to resettle up to 3,000 children from the MENA region over approximately a three-year period (UK Government 2016b). In June 2019, the UK Government announced the intention to combine the programs from 2020 onwards, into one global program, with 5,000 refugees to arrive under the government's provisions and an additional number of refugees who would be sponsored by community groups (UK Government 2019).

The resettlement schemes allow for the expression of British values, as is the case for other resettlement countries, through open advocacy for support to specific refugee groups considered à priori to be in need of protection. Some critics might say that resettlement gives governments (and their countries) the opportunity to suggest they are 'doing something' while actually pursuing policies that limit refugee and migrant arrivals under cover of these 'open' approaches. In a similar way, support for countries in the regions of origins of displacement while doing little to develop greater capacity to accept migration and refugee protection at home, is criticized as containment (Bryant 2017).

There is always tension between that part of the national population which is resistant to migrant and refugee arrivals, and that part which sees the humanitarian need of others, and has the desire to profile their nation as open and humanitarian in nature. The level of public interest in assisting refugees has increased, and strengthened over recent years, even as the other extreme has been more vocal. The increase in public interest in supporting refugees is perhaps particularly pronounced as high numbers of Syrians have been displaced by conflict since 2011 and 'Welcome' movements of various sorts began in different European countries. Several civil society organizations, such as Citizens UK, pressured the UK government to allow local, civil society groups to play a greater role in assistance programs. This pressure started in around 2014, and in October 2015 the government 
announced it would investigate the possibilities for Community Sponsorship. The scheme was launched in 2016, with a first refugee family being welcomed in Manchester in November 2016. By the end of 2018, more than 200 refugees had arrived in the UK, sponsored by some 140 groups (Sponsor Refugees 2019). These sponsored places did not add to the total anticipated arrivals on the programs, but may have contributed to the expansion to refugees of different nationalities impacted by the Syrian conflict, allowing the arrival of mixed nationality families (ERN+ 2017 scoping sponsorship).

Although the potential for sponsorship had been present from the start of the Gateway Program, with evidence tabled in Home Office conferences and reports reflecting on the Canadian experience with this approach, in particular, it required pressure from would be sponsors for the approach to be adopted (see van Selm 2003; Gelsthorpe 2003), largely mirroring the initial establishment of private sponsorship in Canada for the Indo-Chinese in 1979 (CCR 2014).

Interest in sponsorship is broadly based on a range of humanitarian, humanist, cultural and faith-based values. The motives for sponsorship in the UK, noted by Sponsor Refugees are (Sponsor Refugees 2019):

- It is a practical way for local people to respond to the global refugee crisis

- It provides a safe and legal route for refugees to come to the UK

- It makes maximum use of the capacity, commitment and networks of citizens to help refugees

- It improves the chances of refugees to settle in, learn English and find work

- It strengthens community bonds

- It sends a strong message that refugees are welcome in the UK.

Community sponsorship in the UK has been significantly inspired by the long-term success of private sponsorship of refugees in Canada, and supported in various ways by the Global Refugee Sponsorship Initiative (GRSI) set up by the Government of Canada, University of Ottawa, UNHCR, Giustra Foundation, and Open Society Foundation (GRSI 2019).

The total number of active sponsors remains relatively small compared to the total UK population, yet the small and quite recent programs are being positively reviewed by participants and observers. In particular, the facilitation of early integration and independence within local communities is being lauded in early evaluations of the community sponsorship approach (Alraie et al. 2018).

For the purposes of this chapter, the focus is on civil society actors as representative of particular norms and values in national society, and as connectors between refugees and broader society, as well as between governments (national and local) and populations, including the refugees. The role of civil society actors (both established taking on a new role, and new 
organizations formed for the purpose of sponsoring refugees) in community sponsorship is primarily that of facilitator - a prime example of the shifting trends in civil society's place in local and national processes (World Economic Forum 2013).

\section{Conceptualizing community sponsorship: values in action}

One way to try to understand the values at work in community sponsorship is to ask the simple question 'Why does someone want to sponsor refugees?' Refugee integration, particularly in a welfare state context in the UK, is generally thought to be the responsibility of governments, both national and local. What makes individuals or groups decide or suggest that they could sponsor refugee newcomers?

One category of answer would be in the personal realm: the refugee or family to be sponsored are related to, or known to, those sponsoring them. In some sponsorship situations in Canada, for example, the sponsored refugee can be identified by the private sponsors - and might be a relative of the sponsor, or of someone already in their community. In that case, "Why sponsor?' might be relatively easily answered as it is a direct way to assist a known individual or family.

However, in the UK, the refugees who are recipients of community sponsorship are identified by the government in collaboration with UNHCR (similar to the Blended Visa-Office Referred Program in Canada). The person or family being sponsored is therefore unknown to the sponsors and they are randomly matched. The reason to sponsor refugees is therefore based on broader, humanitarian values.

Another category of answer would be to expand programs by putting in financial or in-kind support (e.g. housing) for more refugee arrivals than those for whom the government has said it is prepared to pay. Sponsors, in the UK context, commit to provide housing for the first two years in terms of managing the relationship between the refugee tenant and the private landlord. The housing is actually paid for through housing benefits, however, and the actual financial commitment of the sponsors is relatively limited. Furthermore, sponsored refugees have been part of the overall caseload, not an addition to it, although changes to the UK resettlement program announced on June 18, 2019 mean that sponsorship places will, as of 2020 , be over and above the government program numbers (UK government 2019).

Indeed, the main role of sponsors in the UK is that of facilitators - a bridge offering guidance as well as some material assistance in the earliest days, and in some ways mentors, with a changing relationship over the course of time, as the refugees start to both integrate in wider society and become increasingly independent. Sponsors must be registered charities, and have permission from their local authorities to engage with the refugees, who will be housed in proximity to their sponsoring organization (ERN+2017). 
A third category of answer to the question 'Why sponsor' could be more pertinent, namely as an expression of commitment, values, and, in essences, of political approach to the thorny issues of immigration and protection. Perhaps the strongest underlying motives for sponsorship in the UK are involvement, and the expression of support for refugee arrivals - an expression which may be targeted not only at the refugees, but also at the UK government and at those people in society who oppose refugee arrivals, and/ or engage in far right and racist politics.

One recognized sponsorship organization, Migrants Organize, based in London says on their website:

One of the core benefits we see with community sponsorship is how it creates a strong network of allies, friends and neighbors to support newly arrived refugees who would otherwise be marginalized and isolated - from simple things like helping the family register with the GP and navigate public transport, to being a friendly face to chat with over a coffee. It is about having a community network invested in supporting them toward independence and to break down the loneliness and isolation often experienced by newly arrived refugees.

(Migrants Organize 2019)

Of the values claimed to be British values, the key elements here seem to be individual freedom (the liberty to choose to assist a newcomer, and the freedom of that individual or family to accept that help, or indicate where they are ready to do certain things alone), and tolerance. The toleration of newcomers, of their diversity, of their difficulties in adjusting, and of the whole group of helpers is key to making a success of the sponsorship, and central among the values being upheld through deeds and passed on to those receiving the assistance.

In setting out the Community Sponsorship Program, the government referred to $\mathrm{UK}$ values (using that term, not British values) only to explain that opposition to those values, or tolerance of such opposition, would be reason for refusing an organization the right or opportunity to sponsor refugees (UK Government 2018):

If we consider that your organization or the lead sponsor are not fit and proper to assume the responsibility of resettling a vulnerable family, we may refuse your application or revoke your approval. Reasons for this include, but are not limited to: the provision of false or inaccurate information; vocal or active opposition to fundamental UK values (or tolerance of such opposition) including democracy, the rule of law, individual liberty, universal human rights, gender equality, equality of opportunity, mutual respect and tolerance of different faiths and beliefs, freedom of speech; criminal convictions; immigration offences; or other illegal activity. 
Those organizations that have sponsored refugees are primarily faith-based (Christian) or part of the Refugees Welcome movement, and are following through on their strongly held values (Howden 2016). One question is whether their actions can help spread those values, and particularly tolerance, more deeply across the British population.

\section{Spreading values}

Actions speak louder than words: the expression of values among the community supporting refugees might fly largely under the radar of the wider population, particularly in larger city context, but the action of showing support, is known to the individual refugees and families concerned as well as among the sponsoring community. By requiring groups, NGOs, churches, and others to be broad, registered, and established, the British sponsorship model is essentially requiring both a basic standard and duty of care, and that it is a community, not just one or two individuals, that assists the refugee. The effect of this is to make sponsorship a kind of social gathering place, of community activity. The Church of England, reporting on the impact of sponsorship, says:

The astonishing fact of Community Sponsorship is that it works in any community, large or small, urban or rural. Recent figures published by the Home Office show that the region with the highest number of schemes is the rural South West. A family resettled in Ottery St Mary decided to call their baby daughter Mary in recognition of the friendship and support they have received from the community. The last two years have shown that an increasing number of communities are getting involved. In so doing they have discovered that helping to transform the lives of a resettled family, they have transformed their community for the better in the process, with greater communication, cohesion, and integration.

(Church of England 2019)

In other words, the act of sponsorship is not only an expression of values, but also a strengthening and spreading of those values within and beyond the group directly involved. Indeed, sponsorship brings opportunities to those who sponsor as well as to those they assist

Community sponsorship is a big commitment for any community group but has benefits beyond assisting newcomers to resettle; it offers communities the opportunity to flourish and brings them closer together through active participation and engagement with diversity.

(Alraie et al. 2018: 1)

Research on resettlement to the UK, not necessarily focused on sponsorship, shows that having support from the community, having connections, 
mentors, and guides to assist in the process, is a positive aspect in advancing the integration process (Collyer et al. 2019: 8). It facilitates other aspects of the integration path, such as access to education, learning the language, finding safe, secure, and stable housing.

As such, it is clear that the early findings on experience with Community Sponsorship in the UK find not only positives in the opportunities for integration of the refugees who are sponsored, but also a strengthening and spread of those values labelled 'British,' including tolerance and appreciation of diversity of all kinds.

\section{Tolerance - in short supply in a changing context?}

In his 1997 collection 'On Toleration,' which started as a series of lectures in Yale's Program in Ethics, Politics and Economics, Michael Walzer discusses tolerating and being tolerated as 'the work of democratic citizens,' work which is neither 'easy or insignificant' (Walzer 1997: xi).

Tolerance, as described in the policy papers on British values is about differences - specifically those in faith. Defending toleration, Walzer says, does not have to mean defending difference, although it often does. 'Toleration makes difference possible; difference makes toleration necessary' (Walzer 1997: xii).

Toleration is essentially about peaceful co-existence built on some form of mutual respect and acceptance. There are differences, therefore, following Walzer, we need toleration. Where immigration is concerned, however, a fundamental issue arises. Those who do not wish to tolerate see the answer as keeping out the differences by keeping out the migrants. The differences migrants bring (adding to differences already present) require toleration - in trying to reject those differences by rejecting the migrants, those who would oppose their arrival enter a spiral. The British value of tolerance is sorely tested by their intolerance.

Walzer identifies five 'regimes of toleration,' or models for a tolerant society: multinational Empires, International Society, Consociations, NationStates and Immigrant Societies. Great Britain has perhaps been through some of these, but is having difficulties with the last. Arguably, the British value of tolerance would have been grounded in its days of Empire - for all the prejudice and endemic corruption of the regime, the Imperial power may have been more even-handed towards ruling than any local prince or tyrant, as Walzer suggests. Post-empire as a variant on the 'consociation' of a United Kingdom of four parts, or as a nation-state (which various British citizens and governments may have viewed differently over time), the UK has had another regime of toleration broadly speaking at home.

However, where the UK struggles is with the consequences of Empire, the immigration of Commonwealth citizens with status and rights based on the changing relationship between their (newly) independent states and the UK, and the immigration of others, including EU citizens in the more recent 
regional/supra-national 'consociation.' Walzer treats France, and the 'European Community' as complicated cases. The Immigrant Societies in Walzer's theorizing on toleration are Canada, the US, and Australia. France is complicated because it is a nation-state that has accepted and assimilated a high-degree of its own colonial immigration pre- and post-independence of those states to which its imperial power spread.

The UK's difficulties with its essential value of tolerance in the first two decades of the 2000s may come from its changing nature as a society. Those for whom the values are central can tolerate, and show not only tolerance of but also support to a wider range of 'others' than those that Britain already contains. Those for whom the nation, Britain, is central, can espouse tolerance of others who are British, but a little different, but have difficulties extending tolerance to others arriving in the UK. The UK has become a very complicated case, where tolerance is espoused, but toleration not shown by all.

Those who represent the value (British or otherwise) of toleration by forming community organizations to support resettled refugees through sponsorship, uphold their country in its fundamental ability to tolerate difference and survive.

\section{Conclusion}

This chapter set out to present thoughts on the connections between British values, immigration and refugee protection, and through the prism of community sponsorship to comment on the nature of tolerance in a changing UK society and political nation.

The overwhelming sense to emerge is that there is a broad base of tolerance for difference in Britain, even if it is being sorely tested by the question of how much intolerance can be accepted. Walzer points out that tolerating the intolerant is not such a thorny issue as it is often portrayed to be. Some key aspects, from a political perspective, he says, are separating church and state, and separating politics from the state. Community sponsorship, if understood in part as taking on the government's job of working to integrate refugees in society, practiced primarily by faith-based organizations might be on tricky ground in terms of separating church and state, although clearly not all sponsors are faith-based and they are not, strictly speaking doing the state's job, but society's.

Separating politics from the state is a much more problematic proposition in today's Britain, where the continued existence of the state, and its international and regional political associations and trading arrangements are subject to entirely political decisions - but that goes beyond the realms of this chapter.

Returning to the three questions posed in introducing the chapter: how can we conceptualize participation in community sponsorship efforts from a values perspective? How could sponsorship of refugees by a few spread those values to, or strengthen those values in others in society? How can tolerance 
be understood, and developed, in a country where immigration has happened more quickly than its core citizenry has managed to adapt to it?

The discussion set out above has shown that conceptualizing participation in community sponsorship from a values perspective rests largely, but not exclusively, on tolerance. Sponsors set out from the desire to ensure a smooth path to both integration and independence on the part of refugees for whom they feel a deep sense of humanitarian empathy. Their values might, quite quietly and on a step by step basis, spread to others in society, although the fissures in the UK run deep at this juncture. A major reason for those fissures is that a significant part of the British population has not been prepared, or is not ready, for the changes in immigration that recent decades have brought. The problematic approach to values and their connection to immigration and refugee protection, as to broader political issues in the UK today, are deeply rooted in the transition from Empire to participant in a regional political and economic regime designed to bring peace and stability. Understanding and resolving those issues goes far beyond this study, but reflecting on approaches such as sponsorship, which promotes human interaction, understanding and tolerance, is one way to start addressing these problems through practical measures.

\section{References}

Alraie, M., Collins, H., \& Rigon, A., in partnership with Citizens UK (2018). A Comparison of Community Sponsorship and Government-Led Resettlement of Refugees in the UK: Perspectives from Newcomers and Host Communities. September 2018. Available at: www.ucl.ac.uk/bartlett/development/sites/bartlett/files/comparisonukreset tlement_schemes_fullreport.pdf

Ballinger, S. (2018). Many Rivers Crossed: Britain's Attitude to Race and Integration 50 Years since 'Rivers of Blood'. Available at: www.britishfuture.org/wp-content/uploa ds/2018/04/ManyRiversCrossed2.pdf

Blinder, S. \& Richards, L. (2018). UK Public Opinion towards Immigration: Overall Attitudes and Level of Concern, Migration Observatory. June 2018. Available at: http s://migrationobservatory.ox.ac.uk/resources/briefings/uk-public-opinion-towa rd-immigration-overall-attitudes-and-level-of-concern/

Bryant, J. (2017). The UK and Humanitarian Reform: In Whose Interest? Available at: www.odi.org/blogs/10567-uk-and-humanitarian-reform-whose-interest

CCR (Canadian Council for Refugees) (2014). Canada's Private Sponsorship of Refugees Program: Proud History, Uncertain Future. Available at: https:/ccrweb.ca/sites/ ccrweb.ca/files/psr-overview-challenges.pdf. https:/ccrweb.ca/sites/ccrweb.ca/files/p sr-overview-challenges.pdf" https://ccrweb.ca/sites/ccrweb.ca/files/psr-overview-cha llenges.pdf

Church of England (2019). How Community Sponsorship is Transforming Lives. 11 January 2019. Available at: www.churchofengland.org/more/media-centre/stories-a nd-features/how-community-sponsorship-transforming-lives

Collyer, M. et al. (2019). A Long-Term Commitment: Integration of Resettled Refugees in the UK. University of Sussex. Available at: www.sussex.ac.uk/webteam/gateway/ file.php?name $=4375$-resettled-refugees-report-web.pdf\& site $=252$ 
ERN+ (2017). Private Sponsorship in Europe. Available at: www.resettlement.eu/sites/ icmc/files/ERN\%2B\%20Private\%20Sponsorship \%20in \%20Europe \%20-\%20Expa nding $\% 20$ complementary $\% 20$ pathways $\% 20$ for $\% 20$ refugee $\% 20$ resettlement.pdf

ERN+ (2018). Feasibility Studies on Humanitarian Admission Programmes, Private Sponsorship and Higher Education Scholarships for Refugees. Available at: www.resettlement. eu/page/ern-publications. www.icmc.net/sites/default/files/documents/scoping-paper-icm c-europe-2017.pdf

Gelsthorpe, V. \& Herlitz, L. (2003). Listening to the Evidence: The Future of UK Resettlement. London: Home Office. Available at: https://webarchive.nationalarchives. gov.uk/20080205190743/www.homeoffice.gov.uk/rds/pdfs2/resettlement.pdf

GRSI (2019). Community Sponsoring. Available at: http://refugeesponsorship.org/comm unity-sponsorship

Guild, E. (2000). 'The United Kingdom: Kosovar Albanian Refugees,' in van Selm, J. (ed.), Kosovo's Refugees in the European Union. London: Continuum, pp. 67-90.

Howden, D. (2016). 'Why Britain chose to partially privatize refugee resettlement,' Refugees Deeply, 3 August. Available at: www.newsdeeply.com/refugees/comm unity/2016/08/03/why-britain-chose-to-partially-privatize-refugee-resettlement

Jarvis, L., Atakav, E., \& Marsden, L. (2017). 'What British Muslims think about the term "British Values", The Conversation, 30 October. Available at: https:/the conversation.com/what-british-muslims-think-about-the-term-british-values-86423

Migrants Organize (2019). We're Becoming Community Sponsors - You Can Too. Available at: www.migrantsorganise.org/? $\mathrm{p}=27545$

Richardson, R. (2015). 'British values and British identity: Muddles, mixtures, and ways ahead,' London Review of Education 13(2), pp. 37-48.

Rutter, J. et al. (2018). National Conversation on Immigration: Final Report. Available at: www.britishfuture.org/wp-content/uploads/2018/09/Final-report.National-Conversa tion.17.9.18.pdf

Selm, J., van. (2003). 'Lessons on resettlement from the US and Canada,' in Gelsthorpe, V. \& Herlitz, L. (eds) Listening to the Evidence: The Future of UK Resettlement. London: Home Office, pp. 33-43.

Sponsor Refugees (2019). Welcome. Available at: www.sponsorrefugees.org

UK Government (2011). Prevent Strategy. Available at: https://assets.publishing.service. gov.uk/government/uploads/system/uploads/attachment_data/file/97976/preventstrategy-review.pdf

UK Government (2016a). Gateway Protection Programme. Available at: www.gov.uk/hm rc-internal-manuals/tax-credits-manual/tcm0290170

UK Government (2016b). New Scheme Launched to Resettle Children at Risk. Available at: www.gov.uk/government/news/new-scheme-launched-to-resettle-children-at-risk

UK Government (2017). Syrian Vulnerable Persons Resettlement Scheme: Guidance for Local Authorities and Partners. Available at: https://assets.publishing.service.gov.uk/ government/uploads/system/uploads/attachment_data/file/631369/170711_Syrian_ Resettlement_Updated_Fact_Sheet_final.pdf

UK Government (2018). Guidance for Prospective Sponsors (first published July 2016, updated December 2018). Available at: https://assets.publishing.service.gov.uk/gov ernment/uploads/system/uploads/attachment_data/file/764990/2018-12-04_Comm unity_Sponsorship_Guidance.pdf

UK Government (2019). New Global Resettlement Scheme for the Most Vulnerable Refugees Announced. Available at: www.gov.uk/government/news/new-global-resettlem ent-scheme-for-the-most-vulnerable-refugees-announced 


\section{J. van Selm}

Walzer, M. (1997). On Toleration. Yale University Press: New Haven

World Economic Forum (2013). The Future Role of Civil Society. Available at: www3. weforum.org/docs/WEF_FutureRoleCivilSociety_Report_2013.pdf

Yates, K. (2016). "How the E.U. referendum exposed how toxic "British Values" really are,' The Fader. Available at: www.thefader.com/2016/06/30/eu-referendum -britsh-values-essay 


\section{Crisis and Willkommenskultur \\ Civil society volunteering for refugees in Germany}

Therese Herrmann

The German experience of the so-called refugee crisis in 2015 and 2016 was closely linked to the mobilization of large-scale civil society support for incoming refugees. By autumn 2015, when the number and circumstances of asylum seekers arriving in Germany had come to be referred to as a 'crisis,' volunteering to support the newly arrived refugees became an activity of national significance, both in terms of the unprecedented number of people involved and the large amount of overwhelmingly sympathetic attention volunteers received in cross-party politics and the media. Katrin GöringEckhardt (2015), then co-leader of the Green Party, summed up the dominating atmosphere by linking the situation to Germany's hosting of the football World Cup in 2006 - a time when patriotism had surged amidst the redefinition of German national identity around the values of hospitality and cosmopolitanism - and calling Germans 'world champions in providing help' (Weltmeister der Hilfsbereitschaft). Even the country's largest tabloid newspaper, the center-right BILD-Zeitung, whose polemics have often targeted immigrants, joined in the mood of humanitarian outreach by starting its own campaign to sign-up celebrities and business leaders to assist newly arrived asylum seekers. Notably, the BILD hilft campaign used the slogan 'Refugees Welcome' as part of its logo, previously the sole domain of political activists from anti-border and human rights contexts. If the crisis context gave migrant support predominantly humanitarian connotations, it did, at least temporarily, have the underpinnings of a normative cosmopolitanism, since it suggested both that Germany was under an obligation to take in refugees, and that the diversification of Germany's population resulting from refugees' immigration was a good thing.

In hindsight, the temporary alignment of the refugee crisis discourse, the mainstreaming of pro-refugee volunteering and pro-migrant political positions disintegrated. Under the crisis paradigm, German and EU migration policy has seen some of its severest restrictions in years, both in terms of access to protection, and in terms of integration. While the EU is actively pursuing the externalization of protection obligations to third countries, despite their lack of Geneva Convention standards for refugees (Lübbe 2018), Germany has, in the period between 2015 and 2017, introduced 
residence requirements for recognized refugees, re-introduced the possibility to cut social security benefits below subsistence level for rejected asylum seekers, abolished the right to family re-union for persons with subsidiary protection status, and made analyzing and saving asylum seekers' mobile phone data standard procedure, in violation of the right to informational selfdetermination. ${ }^{1}$

These restrictions were introduced while policy-makers in Germany explicitly praised volunteers, often simultaneously emphasizing that Germany would not have been able to manage the refugee arrivals without them and that they represent the best of what Germany stands for (GöringEckhardt 2015; Gauck 2015; see also, Speth 2017). How, then, to square Willkommenskultur [Welcoming Culture], Germans' unprecedented public commitment to supporting refugees, with the outcome of a more restrictive asylum and border policy? More specifically, I would like to look at the role of the 2015 and 2016 refugee volunteer movement within the dynamics of Germany's migration policy restrictions. Was civil society's support for incoming refugees mostly a humanitarian movement that, eventually, ended up re-enforcing the exclusionary mechanisms it had briefly suspended, as some commentators have claimed (Graf 2017; Steinhilper \& Fleischmann 2017; Ratfisch \& Schwiertz 2015)? Or do volunteers testify to the polarization of German society with regard to migration issues? In other words, were the asylum policy restrictions passed in spite of and not in line with the unprecedented popularity of pro-refugee volunteering? The question bears on wider issues of how to approach recent authoritarian and communitarian challenges to cosmopolitan projects, including that of the European Union itself. We can understand the convergence of Germany's pro-refugee volunteer movement with an increasing restrictiveness in migration politics as testimony to a deepening cosmopolitan-communitarian cleavage (see Teney et al. 2014). But the fact that pro-refugee volunteers often entertained cooperative rather than antagonistic relations to government agencies, plus, as we shall see, their ambivalent attitudes to immigration also makes plausible a different story. Germany's converging of hospitality and restrictiveness would then imply not so much a deepening of social antagonisms but a change in public reasoning about what it means to be cosmopolitan.

I will approach the question about pro-refugee volunteers' role within the wider developments of Germany's 'refugee crisis' by analyzing available data in light of the normative commitments pro-refugee volunteers have expressed, both through their actions and as personal attitudes. While the available data do not allow for a comprehensive evaluation of these because no single data set integrates questions on volunteers' motives, values, political attitudes, and general moral commitments, I maintain that a combined review of the available quantitative and qualitative data does yield some conclusions about how Germany's surge in refugee support volunteering fits into wider developments. ${ }^{2}$ First, data on post-2015 volunteers show that they are more skeptical towards questions of access and less inclined to see a 
political dimension in their activities than previous generations of refugee supporters. Second, additional data on volunteers' individual values and motives highlight a strong emphasis on humanitarian values and reveal a surprisingly strong degree of civic identification among volunteers. Third, data on volunteers' activities and forms of organization as well as qualitative studies on volunteer groups in local settings reveal that, on the ground, volunteers pursued a diversity-sensitive and inclusion-based understanding of integration - one that was often mediated through a strong identification with local communities.

\section{Refugee support volunteering: leap in numbers, shift in outlooks}

Since 2015, civil society support for refugees in Germany has not only dramatically increased in numbers, but it has also undergone a qualitative shift. Whereas migrant support has had a social movement character before 2015 - focusing on political change, often via public protest and acts of civil disobedience foregrounding migrant agency (see della Porta 2018; Rosenberger et al. 2018; Forschungsgruppe 'Staatsprojekt Europa' 2014) - it has mostly focused on concerns of humanitarian support and integration since. Representative data on volunteering in Germany (Simonson et al. 2014; Gensicke \& Geiss 2009) and volunteering in support of refugees and migrants, more specifically (Ahrens 2017; Allensbach 2017; Jacobson et al. 2017), document the quantitative leap that pro-refugee volunteering has taken amidst the 2015 German experience of the 'refugee crisis.' While refugees and migrants made up less than 1 percent of the targets of volunteer activities in 2014, according to the German Volunteer Survey (Simonson et al. 2014), recent studies have consistently shown that volunteering for refugees has increased more than tenfold, drawing around 11 percent of the German population between 2015 and 2017 (Ahrens 2017; Allensbach 2017; Jacobson et al. 2017). As such, it became the second most popular of all volunteering activities, topped only by volunteering within sports clubs (Simonson et al. 2014). Taking into account not only active support, but all those who had volunteered for refugees at least once between 2015 and 2017, the influential conservative Allensbach Institute for Public Opinion Research sees the share of Germans involved in refugee support rising to 25 percent. If one also counts donations and political engagement, the number adds up to as much as 55 percent of the population (Allensbach 2017).

This surge in pro-refugee volunteering has been accompanied by a qualitative shift in both the volunteers' socio-economic composition and their normative outlooks. The volunteers' demographic make-up differs markedly from that of pre-2014 migrant supporters - they are older and more rural than their predecessors, coming closer to matching the overall structure of the German population. While Karakayali's and Kleist's (2016) data suggest that at least a third of pre-2015 volunteers were aged below 30 and a disproportionate amount of them were students, supporters who became active 


\section{4}

T. Hermann

from 2015 onwards were typically middle-aged or older. Similarly, while the majority of volunteers were recruited in cities before 2015, volunteers have mostly been recruited in small and medium-sized towns or rural areas after 2015. The only factors that clearly and consistently set volunteers in refugee support apart from the wider population are their relative wealth and high levels of education (Ahrens 2017; Allensbach 2017; Jacobson et al. 2017; Karakayali \& Kleist 2016). While volunteers in other areas, too, tend to have higher levels of education than the population at large (Simonson et al. 2014), this tendency is exacerbated with refugee support volunteers, of whom a clear majority has completed upper secondary education - compared to around a third of Germans overall. The effect is even more marked when it comes to income levels, with half of the pro-refugee volunteer households situated above the income levels of 80 percent of the general population (Allensbach 2017: 21). Compared to migrant supporters before 2015, who tended to replicate the young and urban socio-demographics of both social movement activists (Karakayali \& Kleist 2015; 2016) and those strata of the population most susceptible to holding cosmopolitan attitudes (e.g. Hanquinet \& Savage 2013; Pichler 2009), Germany's refugee support volunteers in 2015 and onwards have been remarkably cross-sectional. In 2015 , only wealth and education, but not age or affiliation with an urban milieu were decisive in the recruitment of refugee supporters.

The cross-sectional composition of pro-refugee volunteers is matched by data on Germans' political attitudes towards refugees and migrants in 2015. Positive attitudes towards an 'extended Willkommenskultur for migrants in Germany' (Preuß \& Zick 2017: 5), shared by around a third of the population, had become age-independent in 2015 and 2016, whereas in previous years, the youngest generation held significantly more favorable views than the oldest. This pattern is mirrored in opinions on the take-in of refugees: When events started to be referred to as a 'crisis' in 2015, just over half of the German population thought it a humanitarian duty for Germany to take in more refugees, dropping to 37 percent in 2017 (Bertelsmann Stiftung 2017: 12). Pro-refugee views were age-independent in 2015, only to go back to being significantly stratified across generations in 2017. Two years after Germany had publicly embraced Willkommenskultur, less than a third of people over 60 still thought that Germany had a humanitarian duty to take in more refugees, while the youngest generation's pro-refugee attitudes remained stable at just over 50 percent (Bertelsmann Stiftung 2017: 13). In each case, higher education and wealth levels made favorable views significantly more likely. The cross-sectional composition of 2015 pro-refugee attitudes is especially startling if one considers that Germans' attitudes to non-EU immigrants in general, and more specifically, towards receiving refugees had not been excessively positive before 2015. In 2014, less than a third of Germans held favorable views of immigrants from outside the EU, setting Germany below the EU's average, and roughly on par with attitudes in Hungary (European Commission 2014). Asked about the reception of 
asylum seekers in 2014, the majority of the population thought that Germany should have stricter rules and policies (Robert Bosch Stiftung 2014: 23). Interestingly, however, the majority of those in favor of stricter rules of access for asylum seekers also stated that they could imagine volunteering to support asylum seekers (Robert Bosch Stiftung 2014: 32-3), including around 20 percent who could imagine getting actively involved in helping with refugees' integration (Robert Bosch Stiftung 2014: 33; see also Eisnecker \& Schupp 2016: 6-7). Though we can exclude right-wing nationalists from the pool of potential volunteers relatively safely (Beckmann et al. 2017), it does seem like volunteers were also recruited among people without strong cosmopolitan attitudes. Some potential volunteers combined strong motivations to help the incoming refugees' integration with restrictive views on refugees' access.

The gap between attitudes on integration and access is confirmed by a two-part non-representative, but extensive study Karakayali and Kleist (2015; 2016) conducted among refugee support groups in 2014, and 2015. They note a marked shift in the self-understanding and normative outlooks of 2015 volunteers in contrast to those supporters who had started supporting refugees earlier. Only among pre-2014 supporters did a majority support the notion that the basis for taking in refugees should be 'open borders' rather than any particular reason for leaving one's home country, such as human rights violations or, more generally, the idea of forced migration (Hamann \& Karakayali 2016: 78). By contrast, at least three quarters of supporters who started in 2015 seemed to believe that the distinction between refugees and migrants should be upheld. Pre2014 supporters were also more likely to understand their volunteering as an act of support for the right of residence for asylum seekers than later cohorts of supporters (Karakayali \& Kleist 2016: 33). Earlier refugee supporters were not only more concerned with universalizing possibilities of territorial access, but they also understood volunteering for refugees as a political experience more often than those who started later, who in turn tended to think of it more in terms of an emotional experience (Karakayali \& Kleist 2016: 20-1).

In sum, the data on Germany's new refugee volunteers yield ambivalent results about volunteers' normative commitments. It can be observed from the data discussed above that Germany's 2015 surge in refugee support volunteering coincided with a general increase in favorable attitudes towards refugees and migrants. A larger and more cross-sectional share of Germans both thought that Germany should provide wider access to refugees and saw the growth of Germany's immigrant population as something positive. However, we can also observe that, compared to previous refugee supporters, pro-refugee volunteers from 2015 onwards were more prone to understanding their activities as humanitarian rather than political. The data also suggest that volunteering in refugee integration and restrictive views on refugee access are not necessarily exclusive. 


\section{A question of values?}

While comprehensive data on refugee support volunteers' political opinions and normative outlooks are lacking, the Allensbach Institute for Public Opinion Research has collected representative data on 2017 volunteers' values. The data indicate that Germany's new pro-refugee volunteers hold stronger altruistic values than volunteers in other areas, and decidedly stronger altruistic values than the rest of the population (Allensbach 2017: 24). They are a lot more likely than other Germans to name 'helping those in need' and an orientation towards 'social justice' among their value priorities, and a lot less likely than other Germans to prioritize materialist values such as 'a high income, material prosperity.' But to what extent can an understanding of volunteers' values yield insights into their self-understandings and their political positions on questions of migration?

Values, as measured by the Allensbach Institute, are understood as a someone's personal ideas of what is ethically good or worth striving for in their own lives (Allensbach 2013: 10). They do not immediately reflect political opinions: a person might be strongly religious in private, but might still agree with the principle of separating church and state politically. To mark the difference, we would have to look beyond a person's value set to find out where she situates her own identity within her views on society's wider goals and the norms by which it should be governed. ${ }^{3}$

Moreover, even where correlations between values and political attitudes have been measured, values are understood as describing a person's longterm commitments as opposed to their short-term political judgments (Inglehart 1977). Most scholars are of the view that values are acquired through childhood and rarely change throughout a person's adult life (Inglehart 1977; Joas 2001). To explain sudden shifts in an actor's practices or political attitudes, empirical studies on values must, therefore, take into account additional factors that can make sense of the fact that someone previously not particularly concerned with a specific political view or practice, starts taking to it now, rather than before. Germany's 2015 to 2017 leap in pro-refugee volunteering is a case in point. A more situational analysis is required to explain why members of previously unsupportive strata of society came out volunteering for refugees in 2015.

The Allensbach volunteer survey did not only collect data on volunteers' personal values, but also on the motives and triggers that brought them to volunteering. Triggers are understood as the external factors that contribute to causing a person to act in a particular situation rather than in another. Values and motives, on the other hand, both describe internal drivers of action. But while values describe a person's long-term ideas of what is worth striving for in her own life, motives describe the reason a person gives in justifying a particular action (Vorstenbosch 2006) - in this case, starting to volunteer for refugees. Motives, then, include a judgment on the kind of situation a person found herself confronted with before acting, while 
values do not. Therefore, the content of values and motives can, but need not be the same. Religious values, again, make for a good example. Various studies have shown that adherents to religious faiths are overrepresented among refugee support volunteers, with Islam being especially significant (Ahrens 2017: 45; El-Menouar \& Nagel 2017). However, the data also indicate that religious volunteers tended not to think of their faith as an important reason for volunteering (Ahrens 2017: 47; see also Karakayali \& Kleist 2016: 14-15).

In this context, I argue that three aspects stand out when contrasting volunteers' motives in refugee support with the motives volunteers in other areas of society have cited. First, pro-refugee volunteers cited a general altruistic orientation as their prime motive, thereby framing refugee support as a question of humanitarian values. Second, volunteers also understood refugee support as a general duty, not as an activity aligning with their particular interests. Third, volunteers often cited a concern for Germany's future as a motive for their activities, offering a surprisingly civic outlook. I will briefly elaborate on these motives and how they might fit together, before going on to consider criticisms of humanitarianism in the context of refugee and migrant support.

When asked about their motives for getting involved in supporting refugees, pro-refugee volunteers who have started their work since 2015 most often replied 'Because, as a basic principle, I want to do something for others, help them' (Allensbach 2017: 26; see also Pfundmair et al. 2017), thereby re-iterating the altruistic orientation most had already cited as a value. ${ }^{4}$ In my reading, the coincidence of refugee support volunteers' values and motives is not trivial. It implies that volunteers understood the events associated with the 'refugee crisis' as the kinds of situations where their values become important in volunteering. This contrasts with volunteers in other areas, whose most prominent motive - by a margin of almost 20 points - has been enjoying their activities, with specific concern for the group in question and maintaining social networks also featuring prominently (Allensbach 2013: 15). Making volunteering for refugees a case where personal altruistic values matter frames this activity in a particular, humanitarian way. Refugee support volunteers clearly imply that, in doing what they do, they are going out of their normal way to sacrifice time for those they understand to need help.

At the same time, framing helping others as a personal value rather than, say, a duty that simply arose from a given situation relates one's humanitarian behavior back to one's own identity. Obeying duties need not be a question of values. The sight of a drowning person equally obliges all passers-by to do their best to help, independent of what they value personally. It would indeed be strange if the person eventually throwing in a lifebelt would point to her humanitarian values as the motivation to do so, rather than some form of obligation arising from the simple facts of the situation. Explaining the reasons for one's actions in terms of one's personal values, 
then, gives the situation at hand a subjective touch, it implies that someone else might have acted differently if confronted with the same situation (Wils 2006). One acted as one did, on this view, because the basic dispositions of one's personal identity brought one to understand a specific situation as significant.

Apart from linking refugee support to humanitarian values, the motives and triggers most important to refugee support volunteers frame refugee support as a general concern, not as an activity that aligns with their particular interests. Volunteers in refugee support are a lot less likely than volunteers in other areas, such as animal support or music education, to identify their area of volunteering as a single issue focus, that is, a concern they take to be important for themselves, but not necessarily for others (Allensbach 2017: 26). ${ }^{5}$ That Germany's 2015 refugee support volunteers were not motivated by any particular interests to come out in support of refugees is confirmed if one considers the list of triggers that volunteers named. Less than a third indicate that value-specific or issue-specific affiliations, such as being part of a church group or an $\mathrm{NGO}$ with a prior focus on refugees, prompted them to start volunteering (Allensbach 2017: 27). Instead, the majority replied either that they became active on their own initiative, often after seeing media reports, or that personal encounters with refugees triggered them to volunteer (Allensbach 2017: 27). The importance of media reporting underlines the event character the 'refugee crisis' took in the eyes of volunteers. It seems like a substantial proportion of volunteers was prompted to start in 2015, not because of group affiliation or slowly-building peer pressure, but by the impression that something exceptional was happening.

Lastly, I suggest that refugee support volunteers reveal a surprisingly civic perspective on their activities, with many of them stating that they are 'convinced that it is important for Germany's future that the [sic] refugees' integration works well' (Allensbach 2017: 26). ${ }^{6}$ Among the three motives named most often by pro-refugee volunteers, this answer has no equivalent in Allensbach Institute's earlier questionnaire on general volunteers' motives (see Allensbach 2013). It describes volunteering in refugee support as a civic duty rather than a duty immediately held towards refugees. It seems like volunteers who gave this answer espouse a version of the communitarian argument that, in order to function properly, state institutions need some degree of social cohesion at its base, which ensures that there is trust and solidarity among the members of a given society (Miller 2016; Walzer 1984). Moreover, a number of studies confirm that volunteers seem to think, at least partly, that bringing about the kind of social cohesion needed is a task for civil society (Karakayali \& Kleist 2016: 29; Allensbach 2017: 38), rather than just a question of adequate legal provisions. Even though, in this reading, the volunteers' aim was primarily to ensure the functioning of state institutions in the future, their means of doing so were cultural, by advancing refugees' integration to generate what they seem to have taken as the necessary amount of social cohesion at the state's basis. 
Read like this, the data on refugee support volunteers' values and motives suggest that the volunteers combined a focus on humanitarian values with a degree of civic identification. They expressed the latter as a concern for the role played by the refugees' integration in the proper functioning of state institutions. That a combination of humanitarianism and civic identification was a major motive for the volunteers seems to be confirmed by what a number of commentators had critically highlighted when Germany's volunteer movement made headlines in 2015 and 2016. Whereas earlier cohorts of refugee supporters emphasized solidarity and common anti-statist political interests as important themes, some commentators highlight that the volunteers' humanitarian outlooks in 2015 and 2016 were politically useful to reinforce statist policies, marking the influx of refugees as a national state of exception (Graf 2017; Steinhilper \& Fleischmann 2017; van Dyk \& Misbach 2016; Ratfisch \& Schwiertz 2015). In the following section, I take up this discussion and set it in the context of quantitative data on pro-refugee volunteers' more concrete activities and forms of organization as well as qualitative data on refugee support groups' self-understandings and interactions with refugees. Introducing the framework of care ethics as an alternative to humanitarianism, I argue that, on the ground, interactions more often took the form of care relations rather than mere humanitarianism.

\section{Modes of other-orientation: humanitarianism and care relationships}

Was Willkommenskultur an essentially humanitarian movement, and is this the reason why it seemed to have been interested so little in wider questions around migration policy and migrants' rights? A number of German social scientists have applied critical readings of humanitarianism (Fassin 2011; Ticktin 2011; Agamben 1998) to Germany's new refugee support volunteer movement. They have criticized the fact that the volunteers' focus on the passive suffering and immediate bodily needs of the newly arrived refugees has contributed to delegitimizing migrants' self-organization (Fleischmann 2015; Ratfisch \& Schwiertz 2015; Steinhilper \& Fleischmann 2017). Some have also suggested that, by uncritically assuming central tasks in refugee reception that are normally performed by the state, volunteers have - unintentionally - perpetuated the state's withdrawal from these tasks (van Dyk \& Misbach 2016). Lastly, others highlight that the volunteers' continued portrayal around values of altruism and self-sacrifice prompted several politicians to justify the curbing of migrants' rights by pointing to the overburdening of volunteers (Graf 2017; Hinger 2016).

Though some of these criticisms are valid in assessing Germany's discourse on the 'refugee crisis' on the level of national politics and public opinion, I argue that studies on the volunteers' on-the-ground activities suggest that the dynamics were a lot more heterogeneous, often taking the form of care relationships rather than humanitarianism (see also Stock 2017). 


\section{T. Herrmann}

'Care' has been a concept advanced by feminist activists and scholars to grasp, first, the specific type of reproductive labor that has disproportionately been carried out by women within a social division of labor in modern societies (Federici 2012); and, secondly, a specific ethical outlook often associated with care work or with women as care-givers, more generally (Gilligan 2016; Noddings 1984; Tronto 1993). Care relations share some features with humanitarianism: They are also needs-oriented and, as such, establish a hierarchy between the care giver and care receiver. They are also, at least partly, pre-discursive, relying on emotive states and mutual recognition rather than interests and rational argument. However, I argue that there are some important conceptual differences between the care giver and the humanitarian Samaritan. While humanitarianism suggests that someone may bridge the distance to an outsider on the basis of a sense of compassion for the outsider's exceptional suffering, care relations, on the other hand, start from the assumption that bridging differences is not exceptional, but the daily work done in sustaining networks of social relations. Identities, in this view, are not given to be penetrated by outsiders, but are themselves dependent on concrete others' recognition.

Let me briefly identify some of the criteria by which to differentiate care practices from humanitarian practices, before I will go on to outline the extent to which the idea of care ethics describes refugee support volunteers' practices better than humanitarianism. First, care ethics is reciprocal, insofar as it focusses on the relationship over time between a care giver and a care receiver, rather than on the goods an active helper may re-distribute to a passive victim. Although care relationships are unequal, too, in the sense that they happen between concrete individuals with differing needs and vulnerabilities, care ethics assumes that no side of a care relationship is selfcontained. Care ethicists often point to friendships and love relationships to show that care relations are not only exchanges of goods and services, but they also sustain more identity-defining features, such as recognition, trust, and solidarity. Second, care ethics is hence distinguished from humanitarianism by its broad definition of needs. Needs are not only understood physically, but also as the social resources and networks ensuring that a person can develop an individual identity and pursue individual goals in life. Third, care relations are often multi-polar rather than bipolar, focusing on the interdependencies between different poles of a social network (Gilligan 2016; Kittay 1999; Tronto 1993).

Finally, while humanitarianism works to bring close what is remote, care relations assume the otherness of what it near-by. They typically start with the kinds of interpersonal relations that are normally taken to belong to the private rather than the public realm - friendships and family relations, and the informal social relations built in local communities. While feminist care ethicists have maintained that the boundary between private and public is itself contestable (Benhabib 1987; Tronto 1993), it remains unclear how care ethicists can square their emphasis on the special duties owed to the 
significant others of one's immediate social network with obligations to those who are far removed or, like migrants, claiming to be given access to a given community.

From the perspective of humanitarianism, it could have been expected that refugee support volunteers focused their activities on addressing refugees' physical needs, which would privilege making and organizing donations as a form of engagement. Although data on the volunteers' activities confirm that donations indeed made up the largest part of volunteer activities in 2015 (Ahrens 2017: 41; Allensbach 2017: 17), it is noteworthy that the majority of volunteers went on to take on other, mostly integration-related tasks later, such as giving language classes, accompanying refugees to appointments with government authorities, and helping refugees to establish social ties (Ahrens 2017: 41-2; Allensbach 2017: 11-12). In this context, it is also notable that many volunteers chose to describe their activities in non-specific terms, such as 'helping refugees to find their way around here' or 'spending leisure time with refugees' (Allensbach 2017: 17). ${ }^{7}$ Most volunteers, it seems, understood volunteering for refugees as a cross-sectional task, not as conveying a specific skill, but helping with refugees' integration more widely.

A look at the volunteers' forms of organization also speaks against a purely humanitarian outlook. While, from a humanitarian viewpoint, the most preferable type of organization would be whatever is thought to serve refugees' immediate needs most efficiently, volunteers have often chosen forms of organization which run counter to the rationale of efficiency. Most 2015 volunteers founded their own self-organized groups rather than joining an established organization to orchestrate their activities (Karakayali \& Kleist 2016). Up to a third of the volunteers even stated that they organized their activities entirely by themselves, outside of any type of group (Allensbach 2017: 28; see also Mutz et al. 2015: 34). Even though these informal types of organization also testify to the ad-hoc character of Germany's 2015 refugee reception, studies on the relationship between volunteers and municipalities as well as on volunteer groups' forms of funding show that volunteers often upheld and defended them later on. Although volunteer groups often worked closely with local governments in the name of guaranteeing refugees' frictionless integration (Speth 2017), many chose to stay autonomous or demanded on-par relationships, insisting that their work was both necessary for refugee integration to run smoothly and that the specific relations volunteers had forged with refugees through their informal approach were not replaceable by the more formal structures of municipalities and organizations (Hamann et al. 2016; Daphi 2017; Karakayali et al. 2018: 46).

Beyond the data on refugee support volunteers' activities and forms of organization, a number of qualitative studies (Hamann et al. 2017; Karakayali 2017; Hinger 2016; Speth 2017) highlight that volunteers combine a focus on diversity with a strong sense of identification with local communities, adopting an outlook that can be situated within care ethics. Though volunteer activities focused on questions of integration rather than access, volunteer groups 


\section{T. Herrmann}

were often deliberate in distancing themselves from demands of cultural assimilation. In contrast to rights-oriented groups (Steinhilper 2018; Bendix \& Danielzik 2017), some volunteer groups explicitly affirmed what they understood as the refugees' cultural otherness. One study (Karakayali 2017: 20-1), for example, observed that volunteers often expressed the wish to participate in trainings on cultural practices in other countries, so they could better understand how refugees deal with death, mourning, and joy. Though themes of cultural otherness were mostly raised with regard to refugees, a number of studies find that volunteer groups emphasized their own plural composition as well. Many volunteers testified to the diversity of their members and emphasized the performative effects refugee support has had on the integration of their wider communities. Hamann et al. (2017), for example, quote one volunteer from a rural town, who 'realized that founding this initiative brought people who hardly had anything to do with each other to work together and get to know each other' (p. 17). She continues:

So, our group is very variegated, from long-established residents who were born here, I would say, to newcomers ... these people now have something to do with each other and this, of course, has its own impact.

(Ibid. $)^{8}$

In this light, the volunteers' frequent emphasis on their proactive approach to refugee support - in the words of one interviewee: 'Just doing it, just helping, it was wonderful' (Hamann et al. 2017: 8) - must not only be read as a humanitarian suspension of rules and procedure, but also as testimony to their dynamic understandings of community. Local volunteer groups seemed to have understood themselves as creating, rather than defending, the communities they aimed to integrate refugees into (see also Gesemann \& Roth 2017). Their emphasis on diversity, however, did not prevent volunteers from relying strongly on community identity. Indeed, volunteer groups often explicitly motivated local identities, choosing to name themselves after the town or neighborhood their activities were centered in: 'Moabit hilft [Moabit helps],' 'Neue Nachbarn Burtscheid [New Neighbors Burtscheid],' 'Angekommen in Fürth [Arrived in Fürth].' Rather than being seen as a question of rights or particular interests, the volunteers' emphasis on inclusiveness was organized around communal values.

The volunteers' inclusive understanding of integration becomes significant where volunteer groups' cohesion-oriented efforts came up against status distinctions emerging from regional and national asylum and integration policies. Although most volunteers, as I have shown above, conceptually upheld the distinction between refugees and economic migrants, and the stratification of access legitimacy that comes with it, the majority of studies also observe that, on the ground, volunteers often sought to compensate for the differentiation of rights that came with the acceptance or refusal of asylum claims. Thus, volunteer groups often turned to targeting integration 
measures, such as language classes or assistance in searching for apprenticeships, specifically to rejected asylum seekers, who were not eligible for state assistance in these areas (Karakayali 2017; see also Hinger 2016: 84). While their inclusive approach to integration prompted most volunteer groups to adopt critical stances towards local and, more often, regional and national authorities (Speth 2017; Daphi 2017), there is also evidence that volunteer groups influenced municipalities in adopting more inclusive understandings of local identity. For local administration, this meant, in some cases, using their administrative discretion to cultivate deliberately generous interpretations of available legal regulations, for example, when it came to issuing work permits or residence permits on the grounds of good integration (Schammann \& Kühn 2017). In others, it meant the provision of funding and training for programs specifically aimed at the integration of rejected asylum seekers (Schammann \& Kühn 2017).

One last criticism associated with refugee support volunteers' humanitarian approach is that it ignored the contentiousness of social relations. In letting Willkommenskultur appear as a pre-discursive, intuitive, and unified reaction to refugees' suffering, it failed to account for the fact that refugee reception rested on conditions that social movements have fought for - both against existing structures of exclusion and those interests and ideologies that defended them (Steinhilper 2018; Buckel 2013). However, a number of studies find that many volunteer groups sought to create inclusive community identities explicitly against the background of growing anti-migrant sentiments - especially in the East of Germany, where anti-migrant groups had been particularly salient. ${ }^{9}$ They recount situations in which local administration cooperated closely with volunteers explicitly in order to prevent 'the mood from shifting' (Speth 2017: 46) in the face of lingering anti-migrant attitudes. One study narrates a moment where volunteers themselves urged their co-residents in a rural town citizens' assembly to understand the reception of refugees as an identitydefining question, addressing those who had expressed anti-migrant positions: 'Listen, think about it, is this really who you are? What we are doing here is helping people in need' (Hamann et al. 2017: 14). Therefore, it seems inaccurate to claim that volunteer groups had no understanding of their position's contentiousness. It does seem, however, that they dealt with it differently than social movements do - rather than marking divisions and exclusions through the strategic use of protests, petitions, or litigation (Buckel 2013), they understood the project of creating inclusive societies as a question of identity organized around communal values.

\section{Conclusion: values, humanitarianism and care ethics}

What, if anything, then, links the volunteers' preoccupation with humanitarian values and sense of civic identification with their on-the-ground 


\section{T. Herrmann}

concern with creating inclusive local communities? To begin with, it is important to keep in mind the volunteer groups' diversity. As Karakayali and Kleist (2015; 2016) document, in Germany's post-'crisis' refugee support landscape, established migrant support networks, activist groups, and migrant self-organizations overlap with a new volunteer movement that broadened civil society support for refugees beyond its base in urban cosmopolitanism, and changed its aims and dynamics.

Recent volunteers understood their humanitarian values as important motives for getting involved in volunteering. As I discussed, this implied, qua humanitarianism, that helping refugees in the 2015 and 2016 'refugee crisis' context was seen as a basic principled response, rather than a question of specific interests or political agendas. At the same time, it implied, qua values, that volunteers thought it took a specific personal disposition to want to help - one that others may not have. On top of that, many volunteers thought that the integration of incoming refugees was important for Germany's future, which seems to reinforce the idea that volunteers understood Germany's mass refugee intake as an exceptional event, which, if perpetuated, would threaten the functioning of Germany's state institutions. According to this line of thinking, volunteers understood their own task as maintaining the social cohesion they took to underlie the proper functioning of state institutions.

While, from this perspective, it is unsurprising that the volunteers' activities concentrated on a broadly defined idea of refugee integration, on the ground, their practices seemed to have been more inclusive than a concern with humanitarian suffering, on the one hand, and social cohesion, on the other, would suggest. I argued that the volunteers' focus on diversity and sustaining local networks is better understood within a framework of care ethics rather than humanitarianism. On the ground, volunteers have set out to create local identities around diversity and hospitality, in a number of places quite explicitly in contentious circumstances. Here, again, the volunteers' self-understanding appears strongly value based. Rather than framing the reception and integration of refugees as a question of rights, a common political project, or balancing specific interests with others, they worked at preventing 'the mood from shifting.' That is, they worked to ensure - often in cooperation with local administration, though many groups remained independently organized - that a community developed and maintained basic dispositions to view diversity and hospitality positively. In hindsight, this seems to have gone together with, rather than challenged, a re-affirmation of statist politics that can be linked to a more restrictive migration policy. At the same time, there is evidence (see Bendel et al. 2019; Schammann \& Kühn 2017) that the volunteers' emphasis on inclusive community values has contributed to a strengthening of municipalities' self-understanding as actors in their own right when it comes to migration and integration policies. 


\section{Notes}

1 An overview over the many changes in German migration law since 2015 is provided by Flüchtlingsrat Berlin e.V. at: http://fluechtlingsrat-berlin.de/recht_und_rat/a sylg-2015/\#14-8222gesetz-zur-einfuehrung-beschleunigter-asylverfahren8220-8211-a sylpaket-ii (last accessed 10 August 2019, in German).

2 On the empirical study of moral development, see, famously, Kohlberg (1984). On methods for the empirical research of cosmopolitan attitudes, see, among others, Roudometof (2012), and Helbling \& Teney (2015).

3 Ronald Inglehart's (1977) as well as Inglehart's and Pippa Norris's (2019) influential work on value shifts in prosperous societies has built on extensive empirical material to show that political attitudes are indeed grounded in values, which they expect to evolve across generations. Under conditions of continued economic prosperity and relative political stability, Inglehart's (1977) core thesis claims, forthcoming generations will develop increasingly non-materialist values and instead focus on issues surrounding the quality of life, demanding individual selfrealization and social recognition. Inglehart and Norris (2019) have recently updated this theory in the face of the current surge of right-wing authoritarian political movements, claiming that right-wing authoritarianism's recent appeal can be understood as a backlash reaction against the fact that previously hegemonic conservative values are gradually marginalized as new generations develop increasingly 'post-material' value sets.

Much of Inglehart's and Norris's idea that political attitudes can indeed by explained in terms of values is borne out by the fact that they, unlike the Allensbach Institute, understand values as someone's long-term societal rather than personal ends. Even so, it remains disputed to what extent values can inform attitudes to immigration. A study by Helbling and Teney (2015) on cosmopolitan elites in Germany, for example, shows a significant relationship between postmaterialist values and a willingness to help people outside of one's own country, but no relationship between postmaterialist values and openness towards immigrants.

4 All translations from the Allensbach surveys are mine. The German original reads: 'Weil ich grundsätzlich etwas für andere tun, ihnen helfen möchte.'

5 The answer designed to tap this dimension reads: 'Because the refugees who came to Germany are of particular concern to me' (Allensbach 2017: 26). The German original reads: 'Weil mir insbesondere die Flüchtlinge, die nach Deutschland gekommen sind, besonders am Herzen liegen. ' In the Allensbach Institute's 2013 survey on volunteer motivations in general, a version of this answer reads 'Because the area or group that I volunteer with is of particular concern to me, e.g., the environment, children or the elderly' (Allensbach 2013: 15). The German original reads: 'Weil mir der Bereich bzw. die Gruppe, um die ich mich kümmere, besonders am Herzen liegt, z.B. die Umwelt, Kinder oder ältere Menschen.'

6 The German original reads: 'Weil ich davon überzeugt bin, dass es für die Zukunft Deutschlands wichtig ist, dass die Flüchtlinge gut integriert werden.'

7 The German original reads: 'Flüchtlingen dabei helfen, sich hier zurecht zu finden,' and 'Freizeit mit Flüchtlingen verbringen.'

8 All translations from Hamann et al. 2017, are my own.

9 In his narrative account of the events that formed Germany's experience of the 'refugee crisis,' Robin Alexander (2018) recounts that this also goes for the initially favorable reaction of Germany's national government itself. Senior politicians were pushed to take uncharacteristically pro-refugee stances as they responded to a series of violent right-wing attacks against refugees over the summer of 2015 . 


\section{References}

Agamben, G. (1998). Homo Sacer. Sovereign Power and Bare Life. Stanford: Stanford University Press.

Ahrens, P. (2017). Wie blickt Deutschland auf die Flüchtlinge? Erwartungen der Bevölkerung zur Aufnahme von Flüchtlingen zwischen November 2015 und April 2017. Hannover: Sozialwissenschaftliches Institut der Evangelischen Kirche Deutschland.

Alexander, R. (2018). Die Getriebenen. Merkel und die Flüchtlingspolitik: Report aus dem Innern der Macht, 2nd edn. Munich: Penguin.

Allensbach, Institut für Demoskopie (2013). Motive des bürgerschaftlichen Engagements. Kernergebnisse einer bevölkerungsrepräsentativen Befragung durch das Institut für Demoskopie Allensbach im August 2013. Berlin: Bundesministerium für Familie, Senioren, Frauen und Jugend.

Allensbach, Institut für Demoskopie (2017). Engagement in der Flüchtlingshilfe. Ergebnisbericht einer Untersuchung des Instituts für Demoskopie Allensbach. Berlin: Bundesministerium für Familie, Senioren, Frauen und Jugend.

Beckmann, F., Hoose, F., \& Schönauer, A.-L. (2017). 'Einstellungen zum sozialen Engagement in der Flüchtlingshilfe. Empirische Befunde aus einem urbanen Ballungsraum,' in Lessenich, S. (ed.) Geschlossene Gesellschaften. Verhandlungen des 38. Kongresses der Deutschen Gesellschaft für Soziologie in Bamberg 2016. Available at http://publikationen.soziologie.de/index.php/kongressband_2016/article/view/370

Bendel, P., Schammann, H., Heimann, C., \& Stürner, J. (2019). Der Weg über die Kommunen: Empfehlungen für die Flüchtlings - und Asylpolitik der EU, Heinrich-BöllStiftung. Available at www.boell.de/de/2019/02/11/der-weg-ueber-die-kommunen

Bendix, B. \& Danielzik, C-M. (2017). 'Neighbours Welcome! Die Willkommenskultur, die Geflüchteten-Bewegung und die Suche nach Gemeinsamkeiten der Kämpfe um Rechte,' in Hess, S., Kasparek, B., Kron, S., Rodatz, M., Schwertl, M., \& Sontowski, S. (eds), Der lange Sommer der Migration. Grenzregime III, Berlin: Assoziation A, pp. 196-206.

Benhabib, S. (1987). 'The generalized and the concrete other. The Kohlberg-Gilligan controversy and feminist theory,' in Benhabib, S. \& Cornell, D. (eds), Feminism as Critique: Essays on the Politics of Gender in Late-Capitalist Societies. Minneapolis: University of Minnesota Press.

Bertelsmann Stiftung (2017). Willkommenskultur im 'Stresstest.' Einstellungen in der Bevölkerung 2017 und Entwicklungen und Trends seit 2011/2012. Gütersloh.

Buckel, S. (2013). 'Welcome to Europe' - Die Grenzen des europäischen Migrationsrechts. Juridische Auseinandersetzungen um das Staatsprojekt Europa. Bielefeld: transcript.

Daphi, P. (2017). 'Zur Kooperation zwischen Behörden und Zivilgesellschaft in der Unterstützung Geflüchteter. Chancen und Differenzen,' Forschungsjournal Soziale Bewegungen 30(3), pp. 34-45.

van Dyk, S. \& Misbach, E. (2016). 'Zur politischen Ökonomie des Helfens,' PROKLA. Zeitschrift Für Kritische Sozialwissenschaft 46(183), pp. 205-227.

Eisnecker, P. \& Schupp, J. (2016). 'Stimmungsbarometer zu Geflüchteten in Deutschland: Stabil hohes Engagement in der Gesellschaft für Geflüchtete bei weiterhin überwiegend negativer Einschätzung der Auswirkungen der Flüchtlingszuwanderung,' SOEP Papers on Multidisciplinary Panel Data Research (833). Available at: www.diw.de/sixcms/detail.php?id=diw_01.c.531073.de

El-Menouar, Y. \& Nagel, A. K. (2017). Engagement für Geflüchtete - Eine Sache des Glaubens? Die Rolle der Religion für die Flüchtlingshilfe. Gütersloh: Bertelsmann Stiftung. 
European Commission (2014). Standard Eurobarometer 81. Eurobarometer Surveys. European Commission. Available at: http://ec.europa.eu/commfrontoffice/publicop inion/index.cfm/Survey/getSurveyDetail/instruments/STANDARD/surveyKy/2040

Fassin, D. (2011). Humanitarian Reason: A Moral History of the Present. Berkeley and Los Angeles: University of California Press.

Federici, S. (2012). Revolution at Point Zero. Housework, Reproduction and Feminist Struggle. Oakland: PM Press.

Fleischmann, L. (2015). "“We will rise” - Die Stimmen der Geflüchteten in der aktuellen Willkommenskultur hören,' in Bogerts, L. \& Schmertz, M. (eds) Wie unsere Zukunft entsteht - Kritische Perspektiven zu Flucht und Migration nach Europa, pp. 77-86. Available at: www.sicherheitspolitik-blog.de/files/2015/12/Wie_Unsere_ Zukunft_Entsteht.pdf

Forschungsgruppe 'Staatsprojekt Europa' (ed.) (2014). Kämpfe um Migrationspolitik: Theorie, Methode und Analysen kritischer Europaforschung. Bielefeld: transcript.

Gauck, J. (2015). Federal President Joachim Gauck at the opening of the 40th Intercultural Week in Mainz on 27 September 2015. Available at: www.bundespraesident.de/Sha redDocs/Downloads/DE/Reden/2015/09/150927-Interkulturelle-Woche-Mainz-en glisch.pdf?_blob=publicationFile

Gensicke, T. \&Geiss, S. (2009). Hauptbericht des Freiwilligensurveys 2009. Zivilgesellschaft, soziales Kapital und freiwilliges Engagement in Deutschland 1999-20042009. Berlin: Bundesministerium für Familie, Frauen und Jugend.

Gesemann, F. \& Roth, R. (2017). Erfolgsfaktoren der kommunalen Integration von Geflüchteten. Berlin: Friedrich-Ebert-Stiftung.

Gilligan, C. (2016). In a Different Voice. Psychological Theory and Women's Development. Cambridge: Harvard University Press.

Göring-Eckhardt, K. (2015). Speech at the German Parliament. September 9. Available at: http://dip21.bundestag.de/dip21/btp/18/18022.pdf

Graf, L. (2017). 'Asyl, eine Frage der Kultur? Die ambivalente Rolle zivilgesellschaftlichen Engagements im deutschen Asylregime,' Forschungsjournal Soziale Bewegungen 30(3), pp. 56-67.

Hamann, U. \& Karakayali, S. (2016). 'Practicing Willkommenskultur. Migration and solidarity in Germany,' Intersections 2(4).

Hamann, U., Karakayali, S., Höfler, L. J., Lambert, L., \& Meyer, L. (2017). Pionierinnen der Willkommenskultur. Strukturen und Motive des Engagements für Geflüchtete. Berlin: Berliner Institut für empirische Integrations - und Migrationsforschung (BIM), Humboldt-Universität zu Berlin.

Hanquinet, L. \& Savage, M. (2013). 'The Europeanisation of everyday life: crossborder practices and transnational identifications among EU and third-country citizens. Europeanization and globalisation,' EUCROSS Working Paper (6), pp. 120. Available at: www.eucross.eu/eucross/images/docs/eucross_d9_9_europeanisa tion_and_globalisation.pdf

Helbling, M. \& Teney, C. (2015). 'The cosmopolitan elite in Germany: Transnationalism and postmaterialism,' Global Networks 15(4), pp. 446-468.

Hinger, S. (2016). 'Asylum in Germany: The making of the "crisis" and the role of civil society,' Human Geography 9(2), pp. 78-87.

Inglehart, R. (1977). The Silent Revolution. Changing Values and Political Styles Among Western Publics. Princeton: Princeton University Press.

Inglehart, R. \& Norris, P. (2019). Cultural Backlash: Trump, Brexit and Authoritarian Populism. New York: Cambridge University Press. 


\section{8}

\section{T. Herrmann}

Jacobson, J., Eisnecker, P., \&SchuppJ. (2017). 'In 2016, around one-third of people in Germany donated for refugees and ten percent helped out on site - yet concerns are mounting,' DIW Economic Bulletin 2017 (16/17), pp. 165-176.

Joas, H. (2001). The Genesis of Values. Chicago: University of Chicago Press.

Karakayali, S. (2017). “'Infra-Politik” der Willkommensgesellschaft,' Forschungsjournal Soziale Bewegungen 30(3), pp. 16-24.

Karakayali, S. \& Kleist, J. O. (2015). EFA-Studie: Strukturen und Motive der ehrenamtlichen Flüchtlingsarbeit in Deutschland, 1. Forschungsbericht: Ergebnisse einer explorativen Umfrage vom November/Dezember 2014. Berlin: Berliner Institut für empirische Integrations - und Migrationsforschung (BIM), Humboldt-Universität zu Berlin.

Karakayali, S. \& Kleist, J. O. (2016). EFA-Studie 2: Strukturen und Motive der ehrenamtlichen Flüchtlingsarbeit in Deutschland, 2. Forschungsbericht: Ergebnisse einer explorativen Umfrage vom November/Dezember 2015. Berlin: Berliner Institut für empirische Integrations - und Migrationsforschung (BIM), Humboldt-Universität zu Berlin.

Karakayali, S., Wallis, M., Höfler, L.J., \& Heller, M. (2018). Fördermittel in der Flüchtlingshilfe: Was Gebraucht Wird - Was Ankommt. Bertelsmann Stiftung (ed.), Gütersloh. Available at: www.bertelsmann-stiftung.de/de/publikationen/publika tion/did/foerdermittel-in-der-fluechtlingshilfe/

Kittay, E. F. (1999). Love's Labor: Essays on Women, Equality and Dependency. New York and London: Routledge.

Kohlberg, L. (1984). The Psychology of Moral Development: The Nature and Validity of Moral Stages. San Francisco: Harper and Row.

Lübbe, A. (2018). 'GEAS-Reform: Standardsenkung bei den Drittstaatenkonzepten?' Zeitschrift für Ausländerrecht und Ausländerpolitik 2018 (10), pp. 381-395.

Miller, D. (2016). Strangers in Our Midst: The Political Philosophy of Immigration. Cambridge, MA: Harvard University Press.

Mutz, G., Costa-Schott, R., Hammer, I., Layritz, G., Lexhaller, C., Mayer, M., Poryadina, T., Ragus, S., \& Wolff, L. (2015). Engagement für Flüchtlinge in München. Ergebnisse eines Forschungsprojekts an der Hochschule München in Kooperation mit dem Münchner Forschungsinstitut miss. München: Munich Institute of Social Sciences (MISS), Hochschule für angewandte Wissenschaften München.

Noddings, N. (1984). Caring: A Feminine Approach to Ethics and Moral Education. Berkeley: University of California Press.

Pfundmair, M., Lermer, E., \& Frey, D. (2017). “"Willkommen in Deutschland" Motivationen der Flüchtlingshilfe und deren Folgen,' The Inquisitive Mind 2017 (2).

Pichler, F. (2009). 'Cosmopolitan Europe,' European Societies 11, pp. 3-24.

della Porta, D. (ed.) (2018). Solidarity Mobilizations in the 'Refugee Crisis': Contentious Moves. London: Palgrave Macmillan.

Preuß, M. \& Zick, A. (2017). Einstellungen zur Integration in der Bevölkerung. Kurzbericht zum Projekt Zugleich - Zugehörigkeit und Gleichwertigkeit. Essen: Stiftung Mercator.

Ratfisch, P. \& Schwiertz, H. (2015). Antimigrantische Politik und der 'Sommer der Migration.' Berlin: Rosa-Luxemburg-Stiftung.

Robert Bosch Stiftung (2014). Asyl und Asylbewerber. Wahrnehmungen und Haltungen der Bevölkerung 2014. Ergebnisse einer repräsentativen Umfrage. Stuttgart.

Rosenberger, S., Stern, V., \& Merhaut, N. (2018). Protest Movements in Asylum and Deportation. Cham: Springer. 
Roudometof, V. (2012). 'Cosmopolitanism and empirical social research: some methodological issues of an emerging research agenda,' in Delanty, G. (ed) Routledge Handbook of Cosmopolitan Studies. London: Routledge, pp. 115-126.

Schammann, H. \& Kühn, B. (2016). Kommunale Flüchtlingspolitik in Deutschland. Bonn: Friedrich-Ebert-Stiftung.

Simonson, J., Vogel, C., \& Tesch-Römer, C. (2014). Freiwilliges Engagement in Deutschland. Der Deutsche Freiwilligensurvey 2017. Berlin: Bundesministerium für Familie, Senioren, Frauen und Jugend.

Speth, R. (2017). 'Ohne Zivilgesellschaft wäre es nicht gegangen. Helfergruppen und Verwaltungen in Berlin, Mannheim und Starnberg,' Forschungsjournal Soziale Bewegungen 30(3), pp. 46-56.

Steinhilper, E. (2018). 'Mobilizing in transnational contentious spaces: Linking relations, emotions and space in migrant activism,' Social Movement Studies 18(5), pp. 559-574.

Steinhilper, E. \& Fleischmann, L. (2017). 'The myth of apolitical volunteering for refugees. German welcome culture and a new dispositif of helping,' Social Inclusion 5(3), pp. 17-27.

Stock, I. (2017). Daring to Care? How Volunteers and Civil Society Organisations are Shaping Asylum Seekers' Access to Citizenship through Social Support. Bielefeld: COMCAD (Working Papers - Centre on Migration, Citizenship and Development, 156).

Teney, C., Lacewell, O.P., \& de Wilde, P. (2014). 'Winners and losers of globalization in Europe: attitudes and ideologies,' European Political Science Review 6(4), pp. 575-595.

Ticktin, M. (2011). Casualties of Care: Immigration and the Politics of Humanitarianism in France. Berkeley: University of California Press.

Tronto, J. (1993). Moral Boundaries: A Political Argument for an Ethics of Care. London, New York: Routledge.

Vorstenbosch, J. (2006). 'Motiv,' in Wils, J.-P. \& Hübenthal, C. (eds) Lexikon der Ethik. Paderborn: Ferdinand Schöningh.

Walzer, M. (1984). Spheres of Justice: A Defense of Pluralism and Equality. New York: Basic Books.

Wils, J.-P. (2006). 'Wert,' in Wils, J.-P. \& Hübenthal, C. (eds) Lexikon der Ethik. Paderborn: Ferdinand Schöningh. 


\title{
14 Cosmopolitanism at the crossroads Swedish immigration policy after the 2015 refugee crisis
}

\author{
Christian Fernández
}

\section{Introduction: game change? ${ }^{1}$}

Sweden's reputation and self-image as a country of international solidarity and liberal universalism has been cultivated by Swedish governments for more than half a century through peace-building, international cooperation, development, and foreign aid. This trademark has also been influential in Sweden's comparatively open and liberal approach to migration and refugees. It is reflected in an immigration policy that prioritizes humanitarian needs over national self-interest and profitability, and in a multicultural membership policy that prioritizes voluntary integration and social inclusion over forced assimilation and deservingness. Together, these policies have led to a rapid diversification of Swedish society, from a fairly homogeneous country to one of the most diverse in Europe. Prime ministers from left to right have heralded this Swedish model of immigration as a success story. It serves both the 'cosmopolitan' ends of hospitality and refuge, and the national ends of domestic development and prosperity (cf. Schall 2016).

In 2015, the European refugee crisis provided a crucial test of the model. The horrors of the civil war in Syria and affected regions generated the largest displacement of people in Europe since the end of World War II. In the course of one year, roughly one million people migrated to the EU, most of whom were asylum-seekers from Syria, Afghanistan, and Iraq. Prime Minister Stefan Löfven's social democratic-green government, which entered office in 2014, vowed to maintain the strong cosmopolitan commitments of previous governments. The refugee crisis engaged all levels of Swedish society. Questions of numbers and costs were for a long time discarded as irrelevant, and dissenting views were rejected as xenophobic. In September 2015, the Prime Minister declared: 'My Europe does not build walls' (Löfven 2015).

With time and growing numbers of asylum-seekers, however, the general opinion began to sway. In 2015, Sweden registered 163,000 asylum applications. In the peak months of September and October, 10,000 new asylumseekers came every week. Reports of over-burdened migration offices and welfare institutions called into question the feasibility of the cosmopolitan model. The collapsing asylum policy of the EU through the bailout of other 
member states left the 'moral super powers' Sweden and Germany to fend for themselves. In a cruel twist of fate Prime Minister Löfven found himself forced to stop immigration precisely because the numbers of immigrants were so high that the government considered the existing policy unsustainable. The decision was announced in a press conference on November 24 2015 (Löfven and Romson 2015). Torn by moral agony, Löfven and his Vice-Prime Minister Asa Romson (who could not hold back the tears) presented a package of drastic restrictions. In the following months, the government implemented border controls that effectively limited the asylumseekers' possibility of reaching Swedish shores. It then moved to pass a temporary asylum law (2016) that narrowed the grounds for protection and for family reunification to the EU minimum. It also downgraded most residence permits from permanent to temporary. In May 2019, the Swedish government proposed a two-year extension of the temporary asylum law with a restored right to family reunification - which is currently pending in parliament.

What do these changes mean? Are we witnessing the break-up of the Swedish model of immigration? This chapter tries to shed some light on this question by examining Swedish immigration policy pre- and post-2015. While it is too early to either confirm or discard a paradigmatic shift of immigration policy, I will bring out and discuss tendencies that may indicate long-term change towards a more nation-centered politics of immigration. The argument unfolds in the following way. In the first of the following three sections, I describe the Swedish model and explain in what ways it was/ is cosmopolitan. In the second, I examine indications of change from cosmopolitan to national values and priorities, relatively speaking. In the third and last section, I briefly discuss whether this shift constitutes a crisis of values or realities.

\section{Swedish cosmopolitanism}

The term 'cosmopolitan' derives from the Greek words 'cosmos' for 'world' and 'polites' for 'citizen.' Cosmopolitans are world citizens and cosmopolitanism, by inference, is the ideology/theory that seeks to create and strengthen the bonds of fellow citizenship throughout humanity. While the content and thickness of this bond may vary, its universal relevance may not. It denies moral legitimacy to the division of humanity into separate communities, creeds, and tribes. Cosmopolitanism relies both on the principle of individualism, in as much as the ultimate unit of concern is the person (not the group or collective), and the principles of universalism and generality, in as much as all persons are viewed as equals regardless of nationality, gender, skin color, socioeconomic class and, so on (Pogge 1992).

It goes without saying that 'pure' cosmopolitanism is a utopian ideal that has never been realized. Cosmopolitanism is commonly invoked to criticize and question, and to propose more humane policies and practices. More 
often than not, the goal is to attenuate and transform national loyalties, so that governments and people will be more tolerant of strangers and diversity. It is best thought of as an ideal that can be approximated but never reached, especially in a system of sovereign nation-states where solidarity with strangers tends to be secondary to that of co-nationals. Moral cosmopolitans seek to strengthen the horizontal bond between fellow human beings through education and tolerance (cf. Nussbaum 1997), while political cosmopolitans try to strengthen the vertical bond between world citizens and a global regime of individual rights that governments have to protect (cf. Benhabib 2004). States may impose such cosmopolitan obligations on themselves, or through treaties with other states. The cosmopolitan law may also, of course, be imposed upon states by a supranational sovereign or world government, but cosmopolitans have traditionally been skeptical of such concentration of power, regarding it as conducive to new forms of imperialism.

Mobility and migration matter to moral cosmopolitanism because they open the mind and make people more tolerant. They matter to political cosmopolitans partly for the same reason, but also for the sake of global equality and because they create obligations for states, especially with respect to people in need. The most well-known of these is Immanuel Kant's idea of hospitality, or the right to sojourn (Kant 1991). Let us start there and see how it applies to Sweden.

\section{Hospitality and the progressive dilemma}

Kant believed that people, qua human beings, have a shared claim to all parts of the globe, and that this gives them a right of limited access to the territories of states in which they are not citizens/nationals. This right is not as strong and absolute as that of citizens, but strong enough to limit government discretion over entry and exit (Kant 1991). To him, this right was primarily a means to facilitate cross-national mobility and civil association with others, but it also applied to migrants seeking refuge, and this is arguably his most important contribution to modern theories and legislation on migration and asylum (Kant 1991; Benhabib 2004).

Hospitality is often thought of as an act of generosity rather than something that is owed. In Kant's thinking, however, states have an obligation to offer migrants sojourn so long as it does not threaten the states' self-preservation, especially if denying it would result in the migrants' 'destruction.' (This condition is directly reflected in the Geneva Convention's principle of non-refoulement.) The migrant, on the other hand, has an obligation not to abuse the hospitality of the host by staying longer than needed. Kantian hospitality is not a defense of open borders and freedom of settlement, but a (qualified) right to associate with people in other states and to get protection from other states (Kant 1991). While this conception of cosmopolitanism offers a strong and influential defense of the right to asylum, it does not offer 
any clear guidelines on how to balance the state's right to self-preservation against the principle of non-refoulement, or the burdens of hospitality against the needs of the refugees. When does immigration become a threat to the state's right to self-preservation? And when is it safe for migrants to be sent home?

From this perspective, immigration policies operate in a tension between two values, hospitality and self-preservation. The greater the hospitality to immigrants, the stronger the cosmopolitanism; the greater the concern for the state's self-preservation, the stronger the nationalism. The defense of strong cosmopolitanism takes into account not only basic human needs such as safety and survival, but also egalitarian ideals of social justice and fair universal distribution of material resources. To such cosmopolitans, freedom of movement and settlement are causally connected with the right to equal opportunities (Carens 1987 and 2013; Pogge 2008; Tan 2004). The defense of national self-preservation, on the other hand, often relies on the national embeddedness of democratic institutions and social welfare arrangements. Proponents of liberal nationalism argue that democratic participation and accountability, distributive justice and social equality, presuppose a shared national (cultural) identity that fosters and legitimizes trust and reciprocity among citizens (Canovan 2005; Miller 2016; Walzer 1983; Östbring 2019).

Swedish immigration policy has approximated the cosmopolitan end of this duality in at least two ways. Firstly, through criteria of the need for protection of refugees that widely exceeds those stipulated in the Geneva Convention. Since the 1960s, Sweden has offered asylum to war refusers and deserters, and to so-called de facto refugees, i.e. people who do not qualify as refugees under the convention despite suffering severe harassment and discrimination on political ground by the authorities in their homeland. The 1976 Foreigner Law codified Sweden's responsibility to offer these two groups protection. Since the 1980s, an increasingly important ground for protection has been 'humanitarian reasons.' Migrants with physical or mental disabilities belong to this group, as do migrants fleeing conflict that does not target them specifically, but makes it dangerous for them to return. The 1989 Foreigner Law formally recognized humanitarian reasons as a valid ground for protection (Lundh and Ohlsson 1994, Johansson 2005). Furthermore, a generous policy of family reunification has accounted for almost $50 \%$ of the immigration in the 1980 s and 1990 s, and almost $40 \%$ in the 2000s (Dahlstedt 2017). A temporary and notable restriction was made in late 1989 through the 'Lucia decision,' limiting asylum only to refugees who met the requirements of the Geneva Conventions. Since the late 1990s, however, immigration policy has moved in an increasingly liberal (cosmopolitan) direction with increasing numbers of immigrants. In the years between 2006 and 2017, Sweden had the highest rate of asylum applications per capita in the EU-28, and a 50\% approval rate (Eurostat 2018). Additionally, the 2008 labor market immigration law is completely demand- 
driven, and enables employers to recruit directly from third countries (as long as contracts are announced domestically and general rules regarding social rights and minimum wages are met). According to the OECD, Sweden now has the most open labor migration system of the OECD countries (Emilsson 2016).

Secondly, and perhaps more interestingly, the Swedish model combines a moral defense of cosmopolitanism with a pragmatic/causal argument for immigration. While the moral defense relies on the self-image of an altruistic community that stands up for humanitarian values, the pragmatic argument suggests a causal relation between immigration and national progress. This match between the moral obligation to hospitality and the pragmatic benefit of immigration is often repeated in public discourse, for instance in this governmental declaration by Prime Minister Fredrik Reinfeldt:

One of the most Swedish things we have is our tradition of openness to the rest of the world. Generations of people who have fled persecution and poverty have been given a chance to start a new life in Sweden. They have enriched our country, made us wiser, and given us a more developed society. They contribute to our prosperity. Without this openness, Sweden would have been a poorer country.

(Reinfeldt 2010)

The 'progressive dilemma' between humanitarian immigration laws and generous social welfare arrangements that preoccupy many academics and practitioners (Goodhart 2004; Ruhs \& Martin 2008), including several cosmopolitans, tends to be reduced or denied altogether in the Swedish model. Unlike many other 'immigration-friendly' countries, such as Canada and New Zeeland, Sweden does not have an elaborate selection ('points') system for picking the most desirable and profitable migrants. And, unlike other social-egalitarian societies with universal welfare systems, like Denmark, Sweden has not restricted immigration for reasons of self-preservation. Somewhat simplified, Swedish cosmopolitanism is presented and defended as a win-win, morally justifiable and self-serving at the same time.

\section{Postnational membership}

Cosmopolitanism is not just a question of entry and temporary sojourn, but of residence and membership. Although first admission is often intended as a question of temporary stay (guest worker systems, refugee camps), it often develops into permanent settlement. As migrants 'set roots' in the host society and develop social attachments through work, education, civic commitments, and so on, at some point these social attachments should translate into formal membership (cf. Carens 2013). Nation-centered conceptions of membership have traditionally viewed such attachments as a question of singular and sacred loyalties to one community (Brubaker 1992), which 
means that inclusion is a long and arduous process that requires cancellation of previous attachments. Cosmopolitan conceptions of membership, on the other hand, embraces the plurality of attachments and seek ways of formally recognizing them in rights and status. Especially important in this regard is the 'post-national void' that emerges when people live 'between' and/or not completely in one national community.

In a world of increasing mobility and migration, it seems that post-national voids are growing in number, size, and importance. The post-national condition, as Jürgen Habermas (2001) has called it, applies most acutely to migrants, especially the stateless, displaced, and persecuted people - i.e. persons to whom citizenship offers nothing or very little in terms of security. Their vulnerability in a world of nation-states derives from their lack of effective membership, and their lack of membership denies them 'the right to have rights,' in Hannah Arendt's (1973) oft-cited phrase. Cosmopolitanism seeks ways of filling this void by ensuring rights that do not presuppose nationality, although the enforcement and protection of such (human) rights tends to rely on states. A cosmopolitan national society, then, is a society that offers alternative and extensive membership and rights to residents who are not nationals (yet).

Post-national membership can be described as cosmopolitanism applied to a world that is not cosmopolitan in power structure and organization. It applies both to the material elements of membership, status and rights, and to the immaterial ones, identity (cf. Joppke 2010). In the first respect, cosmopolitanism implies the creation of an alternative membership that approximates or even equates citizenship in terms of utility and provisions (cf. Soysal 1994). The stronger the connection between rights and residence, the more cosmopolitan the state.

Swedish immigration policy displays clearly cosmopolitan traits in this regard. Like many other immigration countries, Sweden underwent a process of liberalization between the 1970s and 1990s, by which a monolithic container for national rights gradually opened and became accessible to migrants (cf. Hammar 1990; Soysal 1994; Spång 2011). Sweden differs from most other countries in two respects, however. First, the degree of this expansion went further than in most other countries and included, among other things, the right of denizens (i.e. migrants with permanent residence) to vote and run for office in all elections apart from the national parliament, facilitated naturalization through the abandonment of integration and language criteria, and full acceptance of dual citizenship. Second, unlike most other European countries, Sweden did not experience a civic turn of restrictions on residence and citizenship in the 2000s, but remained faithful to a postnational membership model that is often ranked as the most immigrant-friendly in Europe (Fernández 2019; Goodman 2010; Jensen et al. 2017; MIPEX 2015).

In the second respect, cosmopolitanism implies a re-invention or re-configuration of national identity for the purposes of diversifying the population. To Jürgen Habermas, a key proponent of this idea, it involves stripping 
nationhood of ethnic undertones, and replacing it with a civic (postethnic) conception of the national community. And, it involves disrupting the conflation of majoritarian national culture with the general culture that prevails in the public sphere of politics, business, and civil society (Habermas 2001; 1997). This reconstrual of nationality and nationhood is vital, according to Habermas, because it creates a political culture that is equally inclusive and relevant to all people of society (cf. Pogge's principle of universalism above), and in this sense compatible with immigration, diversity, and political equality (Habermas 1998). Habermas famously connects postnationalism with the ideal of 'constitutional patriotism.' By this he means a patriotism that is expressed through strong popular loyalty to nothing more, and nothing less, than the (universal) norms and values incorporated in a democratic constitution, and its civic political culture and symbols (Habermas 2001, although see Müller 2008 for an alternative, non-cosmopolitan conception). But postnational identity can also mean the deregulation of the nation as a source of political loyalty and relevance. In this version, the nation is reduced to an ethnic community among others in the state, with no claim to over-riding moral and political significance.

I have elsewhere (Fernández 2019) referred to this 'privatization of the nation' as a description that captures the particularities of the Swedish case. It implies on the one hand a form of secularization, whereby the nation, relatively speaking, becomes irrelevant as a source of public identity and legitimacy. Instead, the nation is construed and practiced as a private and voluntary community (much like religious congregations), which rarely lends itself to state sponsored celebrations. On the other hand, privatization of the nation also implies greater fluidity and openness of membership and belonging. It construes citizenship as malleable and open-ended; a bond which is negotiated and re-negotiated by natives and immigrants together, as it were. This notion of membership can be illustrated with the following statement by Ulrika Messing, Minister of Integration in 2000 when the law on dual citizenship was passed:

There is not just one way of being Swedish, but many. Nor is Swedishness something unchangeable. It is continually shaped and reshaped. It develops in encounters with other cultures. Therefore, it is important that we turn Swedish citizenship into an open arena for encounters across ethnic and cultural borders, and that we all participate in shaping the new Swedishness.

(Messing 2000)

This notion of citizenship combines a normative ideal of postnational openness with a causal/empirical claim that integration works best when it is voluntary. Citizenship is not an end goal or a reward, but a means that serves the many purposes of the postnational society. It should be designed 
to accommodate the multiple affiliations and connections that Swedish residents have, and to reduce inequalities between members with different legal status (Fernández 2019; Gustafsson 2002; Schall 2014; Spång 2007).

\section{Signs of change}

So far, I have tried to show in what ways the Swedish model of immigration approximates a cosmopolitan position with respect to entry and membership. The image is obviously very simplified and condensed, and it brushes over variations between more restrictive and more open phases, as well as points of divergence and disagreement between policy-makers and stakeholders. Still, the aim is not to narrate the history of Swedish immigration policy, but to identity defining (cosmopolitan) elements and examine if they are changing as an effect of the refugee crisis. The reminder of the chapter is devoted to the second part of that aim, signs of change. I will discuss three: the return of the progressive dilemma, the new right-left cleavage of party politics, and the re-nationalization of membership.

\section{The return of the progressive dilemma}

One could argue that the Swedish refugee crisis began in the late summer of 2014, one month before the national election. Prime Minister Reinfeldt had built his political career by uniting the center-right parties of the 'Alliance' while maintaining the cordon sanitaire that separated the ascending right-wing populist Sweden Democrats from all the other parties of the parliament. On August 16, he gave a typical campaign speech in all respects but one. Reinfeldt included an unusually emotive plea to the Swedish people to 'open their hearts' to the increasing numbers of refugees that would come and seek asylum in Sweden. It was an unusually candid appeal for tolerance, patience, and solidarity, and an even more unusual and straightforward statement of the costs that refugee reception would entail. Reinfeldt unapologetically explained that admitting and accommodating migrants entitled to asylum would exhaust the room for other political reforms in coming years. Politicians who claimed differently were just lying or deluding themselves. In the long run, however, this was not just the right thing to do, but the best thing for Sweden (Reinfeldt 2014).

Reinfeld's speech was a game changer. It acknowledged the tradeoff between a humanitarian immigration policy and public expenditure for progressive reforms. Although the intention was to motivate the Swedish people to rise to the occasion and be generous, it did not have that effect. Especially not on the voters of Reinfeldt's own party, the Conservatives (Moderaterna), which lost eight percent of its supporters from the previous election (2010) to the Sweden Democrats. The Conservatives lost more than a fifth of their voters (dropping from 30.1\% to 23.3\%), while the Sweden Democrats more than doubled their base (from $5.7 \%$ to $12.9 \%$ ). Reinfeldt's speech changed 
the conception of immigration: if an immaculate champion of Swedish cosmopolitanism could talk so openly about the financial burdens of refugee immigration, how could anyone convince the populace that no such tradeoff existed? Pundits from center to left spent the following months accusing Reinfeldt for playing straight into the hands of the populists - and for breaking a secret agreement not to talk about the cost of immigration (cf. Ulvenlöv \& Gerdås 2014).

During the actual refugee crisis one year later, the dominating public narrative played on moral obligations and pride in the Swedish legacy of solidarity and openness. The crisis engaged all levels of society and the public image featured activists, volunteers and ordinary people doing Samaritan acts. Universities, sports clubs, and cultural organizations opened their doors to migrants with special talents and competence. A positive 'all handson deck' mentality prevailed in the mainstream media (Dahlgren 2016). Gradually, however, this positive discourse was paralleled with another discourse on the public sector, which spoke of lagging welfare institutions, growing inequalities, and declining services for the elderly, the sick, and the unemployed. It is a well-established and very familiar discourse to most Swedes, albeit not one that usually connects with immigration. Rather it is treated as a separate preoccupation with the privatization, dismantling, and eroding quality of public services. In the fall of 2015, however, these two discourses became linked in a way that pitted refugee reception against schooling, housing, and health care for the native population (Dahlgren 2016; Krzyzanowski 2017).

The uniting of the two discourses was initially driven by the Sweden Democrats, of course, who advocated for helping refugees 'in their own regions,' a suggestion that the other parties regarded as crassly xenophobic. Yet, a statement in early October, 2015, by Hans Rosling, a philanthropist and esteemed professor of international health, seemed to support the idea of saving lives on site (in the regional refugee camps) as opposed to just concentrating on asylum in Europe (Rosling 2015). Other public pundits openly addressed the tradeoff between Sweden's humanitarian asylum policy (hospitality) and the basic welfare functions of the state (national preservation). The provisional housing solutions for asylum-seekers - which ranged from expensive hotel accommodations and over-crowded apartments to simple camps in the countryside - fueled the general image of a situation spiraling out of control, socially as much as economically.

While many right-wing populists construed the situation as a choice between Us (Swedes) and Them (migrants), other parts of the political establishment viewed it as a problem of 'administrative capacity.' While Sweden officially remained loyal to its cosmopolitan ideals, the administrative challenges for the Migration Agency and various welfare institutions required support from other member states of the EU. In early November, 2015, Foreign Minister Margot Wallström stated that there were limits to how many refugees Sweden could welcome. At the same time, Prime 
Minister Löfven made a formal request to the EU that some of the asylumseekers in Sweden be divided between other countries (Dahlgren 2016). However, no such relief was offered. Later that month, when the drastic restrictions finally were announced, they were justified as a necessary but morally painful action to salvage the administrative functionality of the Swedish welfare state, not a prioritization of national interests over those of the refugees. If the welfare state ceased to function, everyone would lose, not just Swedish nationals. Although the progressive dilemma finally took its toll on the Swedish model, it was presented as an administrative shortcoming, not a nationalist backlash.

\section{The new right-left cleavage}

The second sign of change is the growing emergence of a new right-left cleavage. The right-center coalition government that entered office in 2006 drove migration policy in an increasingly open, cosmopolitan direction with little opposition from the other parties, save the right-wing populist Sweden Democrats (SD). In fact, maintaining the cordon sanitaire between the growing populist party and the seven other parties was so important that it pushed the whole system to more and more postnational ends. Policies and vocabularies were modelled to signal anti-populism, anti-racism, and liberal humanitarianism. The term 'volumes,' for example, became branded as part of the SD vocabulary and was thereby off limits for anyone who did not want to be associated with xenophobia and ethnic nationalism. Former Prime Minister Fredrik Reinfeldt instead spoke of the abundancy of space in Sweden, and the country's nearly unlimited capacity for refugee reception (Habul \& Svensson 2014). The following social democratic-green government followed suit when it entered office in September 2014.

Unlike most other European countries, the Swedish populists have effectively been out-maneuvered from power and influence by the other parties. Despite the SD's growing electoral support since the early 2000s $-1.4 \%$ (2002), 2.9\% (2006), 5.7\% (2010), 12.9\% (2014) and 17.5\% (2018) - which has turned them into the country's third biggest party, all the other parties from right to left have publicly sworn time and time again never to seek SD's support, let alone invite them into government. With the refugee crisis, however, this cordon sanitaire starts to be questioned. Partly because of the SD's continuous growth in the elections and opinion polls, partly because of the governments U-turn in migration policy in the fall of 2015 . Because of the latter, a number of official truths and sacred principles regarding volumes, welfare state capacity, and integration, became questionable and openly contested. And, positions that previously had been reserved for the SD were now adopted by social democrats, moderates, and even the Green Party $(\mathrm{Mp})$, the most cosmopolitan party of them all. It was as if the pre2015 win-win immigration policy was just a bluff that had been exposed by the migration crisis. 
The cracks in the wall first appeared within the center-right alliance that had been such a stable and cohesive bloc during the Reinfeldt administration (20062014). Slowly but surely, the four parties of the alliance - the Moderate Party (M), the Christian Democratic Party (KD), the Liberal Party (L), and the Center Party (C) - started drifting apart on the nationalism-cosmopolitanism axis, with the former two moving in a more nationalist direction and the latter two in the opposite. In January 2017, when the Moderates' party leader Anna Kinberg Batra announced that her party would consider negotiating with SD, especially to block the government's budget, it was a clear sign that the mainstream consensus on immigration was dissolving. One and a half year later, after the 2018 elections, her successor Ulf Kristersson - who prior to the elections had ruled out any collaboration with the populist - declared himself willing to seek SD's (passive) support in order to break the parliamentary deadlock and form a center-right government with the alliance parties. KD was onboard, but the two other parties refused and ended up supporting the S-Mp government that finally entered office in January 2019, four months after the election.

The center liberal parties' (C and L) support for a left-wing government has driven a wedge right through the bourgeois alliance, and it has altered the basic divisions of the party system. Throughout most of the twentieth century and well into the twenty-first, Swedish politics have been shaped by the conflicts between labor and capital, socialism and capitalism, state and market. Now, the party-political system is increasingly shaped by the conflicts between openness and closure, diversity and cohesion, cosmopolitanism and nationalism. Obviously, this is a gradual and steady change as in so many other European countries, yet exacerbated in Swedish politics by the refugee crisis and its aftermath. It has brought about new divisions in a previously relatively unpoliticized dimension.

It is of course hard to predict how lasting this split of the center-right alliance will be. Developments during the Spring 2019 indicate an ideological divorce on issues of immigration and integration. The Moderates and especially the Christian Democrats have positioned themselves closer to the SD content, as well as collaboration-wise - while the Liberal and Center parties are torn between their support for the government on 'new left' issues (immigration, diversity, openness) and their proximity with Moderates and Christian Democrats on 'old right' issues (taxation, labor market, privatization, etc.). Such alliances may of course change quickly again, in the increasingly volatile Swedish party system. Less likely to change any time soon, however, is the identification of the right with national preservation and the left with liberal openness, the growing salience of this national-cosmopolitan dimension, and the polarization over it.

\section{The re-nationalization of membership?}

The third sign of change relates to the conception of membership. Sweden abolished the remainders of the (largely informal) language test for 
citizenship in the 1980s (Szabó 1997). Since then, several commissioned reports have considered the linguistic component of integration and its connection to citizenship, always discarding it as a mandatory naturalization requirement. The normative reason is that it unjustly excludes some groups from full political membership, such as elderly, people with low or no education, illiterates, people with learning disabilities, and others for whom a formal test would be severely disadvantageous. Performance tests for citizenship simply do not match well with the principles of voluntary integration and universal inclusion. The empirical reason is the lack of evidence for the correlation between language testing and efficient integration. According to this causal argument, language tests are too blunt and inefficient an instrument for promoting language proficiency (see SOU 1999: 34 and SOU 2013: 29). Such proficiency, and integration more generally, is better promoted through encouragement and social inclusion, rather than sticks and carrots, the argument goes.

A new policy seems to be under way, however. In January 2019, the new government declared its intention to introduce a language and civics test as part of the naturalization requirements (PM 2019: 10). The Liberal Party has advocated the introduction of a language test since the early 2000s with little success, but now the circumstances seem to be different. The left-green government depends on the support of a small party that pushes for the formalization of (liberal) naturalization requirements. In this concrete respect, the proposed test is a concession to the Liberals. In a more general respect, it also seems to be the result of renewed interest in 'Swedish values' and the need for 'leitkultur' - an explicit public delineation of what mainstream civic culture is. Arguably, the impulse can be traced back to a debate that began after New Year's Eve 2015/16. From several cities in Sweden (and Europe) came reports of gangs of young men/boys of presumed Afghan and Syrian origin, touching, groping and cornering women in crowded places. The events were rapidly connected with the large inflow of refugees the preceding fall, and publicly construed (by some) as a clash of values: a modern Swedish culture of gender equality and sexual liberation versus an oriental and traditional (Muslim) culture of patriarchy and clan mentality.

Following the New Year's Eve events of 2015/16, Swedish values have reemerged as a political referent in integration policy. In the yearly political summer gathering in the city of Visby 2016, all party leaders made statements in their speeches on Swedish values and how their relation to integration. The stressed values are fairly generic and universal, however, and typically include the central pillars of liberalism (individual autonomy, tolerance) and democracy (free speech, political equality) in combination with more specific issues such as gender equality, sexual liberation, and social egalitarianism. Although the invoked values are sometimes construed in ways that are particularly Swedish, only the SD has connected them with ethnic or thick cultural traits. The central idea of this increasingly influential way of reasoning is that integration does not happen spontaneously by itself, 
as previously believed, but needs to be actively and explicitly guided by the state. Fleshing out the values of membership, albeit vaguely and tentatively, is a way of delineating the pathway to integration - not an attempt to 'purify' the nation.

\section{Conclusion:}

\section{a crisis of values or realities?}

The Swedish policy development after the refugee crisis puts into question the established Swedish model of cosmopolitanism. The challenge is not primarily ideological, in that it did not originate from a populist government or a shift away from established humanitarian values. Rather, the challenge derives from changing perceptions of reality, and more specifically of the causal requirements of refugee reception and integration. In this respect, the Swedish post-refugee crisis is a crisis of realities rather than values, the new reality being a world of potentially unprecedented asylum-seekers, a dysfunctional EU policy under the Dublin regime, and the limited welfare state capacity for refugee accommodation. The values remain the same, but the circumstances have changed, according to the official government narrative.

One could easily argue that this narrative offers a convenient cover-up for a de facto nationalist turn in party politics and popular opinion. Blaming the circumstances is a way to save face without making the sacrifices that the model requires. Overall, however, I think this argument underestimates how proudly invested Swedish governments have been in the values associated with humanitarianism, openness, tolerance, and social inclusion. In particular, I think the argument underestimates the overall commitment Swedish governments have made to the 'win-win theory' of refugee immigration. On this win-win view, it is not simply morally regrettable to restrict immigration when the numbers of asylum-seekers increase, it is nonsensical: if refugee immigration brings longterm economic and social gains, why would any government voluntarily restrict it? The factual restrictions that have been introduced, then, belie the win-win theory of cosmopolitanism and cast doubt on everyone who defended it. In the Swedish case, that includes all the parties apart from SD, which in this respect has come out as the 'winner' of the refugee crisis.

Eventually, the new reality of Swedish immigration policy is likely to affect also the values of immigration policy. This is normally how politics works reality and values tend to go hand in hand. It is a package deal, and if one changes, the other follows, especially in Sweden where the defense of a moral position has relied so heavily on empirical-causal arguments. We enter a phase of 'post-postnational' consensus. The signs of change that I outlined in the previous section are difficult to diagnose with any certainty, of course, but some changes are unlikely to return to the 'cosmopolitan normality.' While the party constellations may change and steer immigration policy in a more or less cosmopolitan direction, the crystallization of a new left-right cleavage will construe and politicize a growing number of issues as instances of the conflict between national and cosmopolitan ends. And, 
while the proposed civic and language tests may amount to nothing, the growing disbelief in spontaneous integration through encouragement and rights is likely to stick. Above all, the tradeoff between numbers and rights has been normalized in public speech and is unlikely to be reversed in the near future. The return of the progressive dilemma urges politicians to weigh cosmopolitan hospitality against national preservation, and to 'sell' their priorities to the voters in a much more direct way than they have been used to. They will be tempted to adjust their values to the new, national reality to make the 'package deals' more cohesive and accessible.

\section{Note}

1 I would like to thank Björn Östbring and Brigitte Suter for helpful comments on previous drafts of this chapter.

\section{References}

Arendt, H. (1973). The Origins of Totalitarianism. New York: Harcourt, Brace and Jovanovich.

Benhabib, S. (2004). The Rights of Others: Aliens, Residents and Citizens. Cambridge: Cambridge University Press.

Brubaker, R. (1992). Citizenship and Nationhood in France and Germany. Cambridge: Cambridge University Press.

Carens, J. (1987). 'Aliens and citizens: The case for open borders,' The Review of Politics 49(2), pp. 251-273.

Carens, J. (2013). The Ethics of Immigration. New York: Oxford University Press.

Canovan, M. (2005). The People. Cambridge: Polity Press.

Dahlgren, P. (2016). 'Moral spectatorship and its discourses: The "mediapolis" in the Swedish refugee crisis,' Jaunost - The Public 23(4), pp. 382-397.

Dahlstedt, I. (2017). Swedish Match? Education, Migration and Labour Market Integration in Sweden. Malmö: Malmö University.

Eurostat (2018). Eurostat database. Available at: https:/ec.europa.eu/eurostat/data/data base

Emilsson, H. (2016). Paper Planes: Labour Migration, Integration Policy and the State. Malmö: Malmö University.

Fernández, C. (2019). 'The unbearable lightness of being Swedish? On the ideological thinness of liberal citizenship regime,' Ethnicities, online first. Available at: https:// doi.org/10.1177/1468796819843531

Goodhart, D. (2004). 'Too diverse?,' Prospect 20 February. Available at: www.prosp ectmagazine.co.uk/magazine/too-diverse-david-goodhart-multiculturalism-brita in-immigration-globalisation

Goodman, S. W. (2010). 'Integration requirements for integration's sake? Identifying, categorising and comparing civic integration policies,' Journal of Ethnic and Migration Studies 36(5), pp. 753-772.

Gustafsson, P. (2002). 'Globalisation, multiculturalism and individualism: the Swedish debate on dual citizenship,' Journal of Ethnic and Racial Studies 28(3), pp. 463-481. 
Habermas, J. (1997). 'Reply to Grimm,' in Gowan, P. \& Anderson, P. (eds) The Question of Europe. London and New York: Verso, pp. 259-264.

Habermas, J. (1998). The Inclusion of the Other: Studies in Political Theory. Cambridge, MA: MIT Press.

Habermas, J. (2001). 'The postnational constellation and the future of democracy,' in Pensky, M. (ed), Jürgen Habermas: The Postnational Constellation. Political Essays. Cambridge, MA: MIT Press, pp. 58-112.

Habul, K. \& Svensson, O. (2014) 'Reinfeldt: Sverige behöver invandring,' Aftonbladet, 7 December. Available at: www.aftonbladet.se/nyheter/a/7ljG43/reinfeldt-s verige-behover-invandring.

Hammar, T. (1990). Democracy and the Nation-State: Aliens, Denizens and Citizens in a World of International Migration. Aldershot: Avebury.

Jensen, K., Fernández, C., \& Brochmann, G. (2017). 'Nationhood and Scandinavian naturalization politics: Varieties of the civic turn,' Citizenship Studies 21(5), pp. 606-624.

Johansson, C. (2005). Välkomna till Sverige? Svenska migrationspolitiska diskurser under 1900-talets andra hälft. Malmö: Bokbox förlag.

Joppke, C. (2010). Citizenship and Migration. Cambridge: Polity Press.

Kant, I. (1991). 'Perpetual peace: A philosophical sketch,' in Reiss, H. S. (ed.) Kant: Political Writings. Cambridge: Cambridge University Press, pp. 93-130.

Krzyzanowski, M. (2017). "We are a small country that has done enormously lot": The "refugee crisis" and the hybrid discourse of politicizing immigration in Sweden,' Journal of Immigrant Eु Refugee Studies 16(1-2), pp. 97-117.

Lundh, C. \& Ohlsson, R. (1994). Från arbetskraftsimport till flyktinginvandring. Stockholm: SNS Förlag.

Löfven, S. (2015). Tal vid manifestationen för flyktingar, 6 September 2015.

Löfven, S. \& Romson, Å. (2015). Regeringens presskonferens, 24 November 2015.

Messing, U. (2000). 'Dubbelt medborgarskap införs,' Arbetet Nyheterna, 3 August.

Miller, D. (2016). Strangers in Our Midst: The Political Philosophy of Immigration. Cambridge, MA: Cambridge University Press.

MIPEX (2015). Migrant Integration Policy Index. Available at: www.mipex.eu/

Müller, J-W. (2008). 'A general theory of constitutional patriotism,' International Journal of Constitutional Law 6(1), pp. 72-95.

Nussbaum, M. C. (1997). Cultivating Humanity: A Classical Defense of Reform in Liberal Education. Cambridge, MA and London, UK: Harvard University Press.

Östbring, B. (2019). Migrationspolitiska dilemman: Om idealism och realism i liberal politisk teori. Lund: Lund political studies.

PM (2019). Utkast till sakpolitisk överenskommelse mellan Socialdemokraterna, Centerpartiet, Liberalerna och Miljöpartiet de gröna. Available at: www.liberalerna.se/wp -content/uploads/utkast-till-sakpolitisk-occ88k-s-c-l-mp.pdf

Pogge, T. W. (1992). 'Cosmopolitanism and sovereignty,' Ethics 103(1), pp. 48-75.

Pogge, T. W. (2008). World Poverty and Human Rights: Cosmopolitan Responsibilities and Reforms. Cambridge: Polity Press.

Reinfeldt, F. (2010). Regeringsförklaringen, 5 October 2010.

Reinfeldt, F. (2014). Sommartal, 16 August 2014.

Rosling, H. (2015). Publicistklubben, 11 October 2015.

Ruhs, M. \& Martin, P. (2008). 'Numbers vs. rights? Trade-offs and guest-worker programs,' International Migration Review 42(1), pp. 249-265.

Schall, E. C. (2014). 'Multicultural iteration: Swedish National Day as multiculturalism-in-practice,' Nations and Nationalism 20(2), pp. 355-375. 
Schall, C. E. (2016). The Rise and Fall of the Miraculous Welfare Machine: Immigration and Social Democracy in Twentieth-Century Sweden. Ithaca and London: Cornell University Press.

SOU 1999 (1999: 34). Svenskt medborgarskap. Slutbetänkande av 1997 års medborgarskaps kommitté.

SOU 2013 (2013: 29). Det svenska medborgarskapet. Betänkande av medborgarskapsutredn ingen.

Soysal, Y. (1994). Limits of Citizenship: Migrants and Postnational Membership in Europe. Chicago: The University of Chicago Press.

Spång, M. (2007). 'Pragmatism all the way down? The politics of dual citizenship in Sweden,' in Faist, T. (ed.) Dual Citizenship in Europe. From Nationhood to Societal Integration. Aldershot: Ashgate, pp. 103-126.

Spång, M. (2011). 'Svensk medborgarskapspolitik,' in Bevelander, P., Fernández, C., \& Hellström, A. (eds) Vägar till medborgarskap. Lund: Arkiv förlag, pp. 29-42.

Szabó, M. (1997). Vägen mot medborgarskap: studier i medborgarskapsbyte och integration. Stockholm: Arena.

Tan, K-C. (2004). Justice Without Borders: Cosmopolitanism, Nationalism and Patriotism. Cambridge: Cambridge University Press.

Temporary Asylum Law 2016 (2016: 752). Tillfälliga begränsningar av möjligheten att få uppehållstillstånd $i$ Sverige.

Ulvenlöv, J. \& Gerdås, T. L. (2014). 'Fredrik Reinfeldts tal banade väg för SD,' Expressen, 10 December. Available at: www.expressen.se/debatt/fredrik-reinfeldts-ta 1-banade-vag-for-sd/.

Walzer, M. (1983). Spheres of Justice: A Defense of Pluralism and Equality. New York: Basic Books. 


\section{5 (Un)Deserving refugees \\ Contested access to the 'community of value' in Italy}

Chiara Marchetti

\section{Introduction}

September 2018, the new Government in Italy has been in office for a few months. Matteo Salvini, the Minister of Internal Affairs and a representative of the populist and racist Lega Party, is drafting his Immigration and Security Decree. Meanwhile, in the rich and Catholic city of Bergamo, the centerleft administration inaugurates the Integration Academy. Strongly promoted by the Major and the local Caritas, and managed by social cooperatives already involved in reception activities, the Academy hosts 30 asylum seekers who voluntarily enter a strict 'military' program: wake-up calls at 6:30, no cell phones during the day, no Wi-Fi after $11 \mathrm{pm}$, and blue uniforms inscribed with 'Integration Academy. Thanks Bergamo!' Volunteer work, such as collecting garbage around the city, is compulsory: at least 20 hours per week. Social relations outside the Academy are strictly limited: participants cannot visit a mosque, browse markets, or meet friends. Violators of the rules are punished, for example, with weekend detention at the center, while well-behaved cadets are rewarded with insignia on their uniforms, or even internships with the Academy's local business partners.

December 2018, Salvini's Immigration and Security Decree has already been converted into Law 132/2018. Despite endorsement from the Bergamo City Council and the Italian Association of Municipalities (ANCI), the Government and Parliament have blocked a proposal to introduce a 'rewarding permit' for individuals holding an A2 Italian certificate, who have performed at least 100 hours of volunteer work, and who are completing an internship or are employed. Humanitarian protection is definitively cancelled. The ordinary reception system is dismantled. The 30 asylum seekers of Bergamo, however, continue to live at the Academy. They work diligently to integrate into the Italian system and to show that they deserve to stay. Their strict training does not guarantee an advantage when facing the Commission responsible for refugee determination, however. By the program's end, the asylum seekers will likely receive only an Academy-issued certificate and not full refugee status, apart from the few individuals deemed worthy. 
What happens when a regime of rights is substituted by a regime of deservingness? What do Italian institutions expect from migrants and vice versa? How do social workers mediate these possibly conflicting expectations? Though it descends from a strong rights-based approach, the asylum system claims to uphold a meritocracy, follows the stair-case model, and embodies the logic of a declining welfare, with its moral economy of what is 'good' and what is 'bad.' Together, asylum seekers and social workers occupy the nexus where models based on rights, deservingness, and control struggle for recognition as the way to deal with Others. All this happens as 'refugees' are increasingly considered to be allegedly 'irregular economic migrants' and must demonstrate that they are not.

\section{Who deserves to be protected?}

Forced migration policies and studies have often evoked the polarity between deservingness and undeservingness. By the 1990s, public debates and practical policy in the UK distinguished between the 'deserving' refugee and the 'undeserving' asylum seeker. Mainstream political debates centered on the notion that the majority of asylum seekers are 'bogus' and therefore undeserving of entry to Britain, and of social support (Sales 2002: 456). While the government has claimed to favor measures encouraging the 'social inclusion' of refugees (Home Office 1999: 3) it has enforced a punitive regime upon their arrival. As Sales writes, 'Official thinking was that 'genuine' refugees would be prepared to undergo a temporary period of hardship since the process would weed out 'bogus' claimants, thus making their own position morally stronger' (Sales 2002: 466).

This politics of suspicion corresponds to the juridical frames introduced during that time, such as those regarding manifestly unfounded and/or fraudulent applications. In a position dated 1992, UNHCR affirmed that 'national procedures for [the] determination of refugee status may usefully provide for dealing in an accelerated procedure with manifestly unfounded applications for refugee status or asylum,' stating that 'clearly fraudulent' situations reasonably includes those where the applicant deliberately attempts to deceive the authorities determining refugee status (UNHCR 1992). In the same year, the Council of the European Union adopted the London Resolution on manifestly unfounded applications (European Union 1992). Both developments demonstrate a specific understanding of deservingness, or that deservingness is: 1 ) connected to the reality of life in the applicant's country of origin (the determination procedure seeks to verify that individual accounts of persecution correspond with stipulations made by refugee definitions), and 2) related to the reliability and credibility of the applicant. Trusting the asylum seeker becomes a matter not only of juridical assessment, but also of moral judgment. The obstacle course of asylum procedure (the 'period of hardship' mentioned by Sales) is thus a kind of test: because mistrust is the prevailing attitude (Valentine Daniel \& Knudsen 1995), confidence must be earned on the ground. 
Refugees' loss of credibility directly connects to the changing phenomenology of forced migrations, which began after the end of the Cold War and with the start of new wars in the 1990s. The decade saw a substantial increase in mass displacement, humanitarian intervention, and the number of civil victims (Duffield 2001). The representative shift from the political refugee, enshrined in the Geneva convention, to the humanitarian victim and apolitical subject - or the 'speechless emissary,' in the words of Liisa Malkki (1996) - raises questions about forced and economic migration. That is:

The refugee as traumatized victim, having lost a heroic political status, is no longer as distinct from the illegal immigrant and is seen as alien to the political community and an alien social burden. Accordingly, we have the rise of the reviled figure of the bogus asylum-seeker.

(Pupavac 2006: 14)

Only 'real' refugees deserve protection, as well as social and political consideration, because only they may sufficiently prove that they are worthy of trust and rights.

The polarity between deservingness and undeservingness has another component, as well. In contemporary democracies, 'communities of value' a fundamental part of modern state narratives - are imagined and socially constructed as communities populated by 'good citizens, law-abiding and hardworking members of stable and respectable families' (Anderson 2013: 3). Unlike Others, these ideal citizens share values and patterns of behaviors, form 'the legitimate us,' and may therefore receive rights:

It is valuable, in the sense of holding values and having virtue and in this sense, it is priceless, but the virtue of its members is also manifest in economic value. The community of value is comprised of law abiding, hardworking, independent people living in responsible families, unchallenged by gender and class relations, but potentially victimized by immigrants, criminals and others. [...] Terms like 'immigrant,' 'foreigner,' and 'asylum seeker' are often not simply descriptive of legal status but are value laden and negative.

(Anderson 2012: 4-5)

In this light, asylum seekers must prove not only that they are 'real refugees,' but also that they are or can train to become 'good citizens.' As Aihwa Ong explains in her seminal study on Cambodian refugees in the US: to 'become 'good enough' citizens, newcomers must negotiate among different forms of regulation and be taught a new way of being cared for, and of caring for themselves in their new world' (Ong 2003: XVII). This process, however, is incredibly difficult. The good citizen faces two related antagonists: the 'migrant' (or the non-citizen) and the 'failed citizen.' Both represent the undeserving poor (the first of global origin and the second, national or 
European $^{1}$ ) and are social constructs that distinguish the community of value from its outsiders. If not actively acknowledged and addressed as a social construct, the directive to be part of the community of value tends to exacerbate societal conflicts, especially among lower socioeconomic groups: 'good,' 'hardworking,' 'legal,' and 'taxpaying immigrants,' for instance, begin to distance themselves from their 'bad,' 'lazy,' 'illegal,' and 'welfare dependent' peers (Oliveri 2014).

Similarities between migrants and failed citizens grow even more evident when considering how welfare works in many neoliberal democracies, where responsibility for structural inequalities is ascribed to the individual and where poverty is interpreted as a result of bad morals and behavior rather than structures, and institutional practices (Rose 1999; Dhaliwal \& Forkert 2016). Neoliberal policies continue to employ a 'staircase of transition' approach in response to homelessness, despite growing evidence that the staircase model fails to reduce homelessness and even diminishes the prospect of housing for homeless people:

Today, social authorities customarily structure their various types of shelter, supported housing, training flats, etc. like a 'staircase,' which homeless people are supposed to ascend step by step from the streets to a regular dwelling of their own via low-standard shelters, category housing (i.e. houses for specific categories, such as homeless male alcoholics), training flats and transitional flats. The higher they climb, the better their conditions in terms of physical standard and space, integrity, freedom, and security of tenure.

(Sahlin 2005: 117; see also Olsson 2008)

Traditionally social democratic countries, such as Sweden or Finland, use this model and it has been historically predominant in the US, where the 'continuum of care' essentially entails 'progressing' homeless people through a series of separate residential services - typically emergency shelter programs, transitional housing, and supportive housing (Johnsen \& Teixeira 2010).

In this moral economy, recipients of aid and welfare are perceived not as subject to forces beyond their control and as possessing the will to be independent but as making inadequate efforts to improve their situations (Yoo 2008). Though the suffering body and the traumatized victim evoke humanitarian reactions, neoliberalism suddenly calls the subject to do their part to enter the community of value (Fassin 2005). They cannot be passive, expectant, or trust in a regime of rights for an extended period. Within the framework of abstract liberalism, meritocracy, and individualism prevail: 'by framing race-related issues in the language of liberalism, whites can appear 'reasonable' and even 'moral,' while opposing almost all practical approaches to deal with de facto racial inequality' (Bonilla-Silva 2006: 28). Like homeless people, asylum seekers actively engage in paths towards autonomy 
and integration. Their career is 'put into effect by offering moves 'upwards' as a reward for good behavior and achievement,' while they are punished with 'eviction or dislocation to a lower step...for rule breaking or a relapse to problematic behavior' (Sahlin 2005: 118).

Who, then, deserves protection? It seems that any answer is inextricable from moral considerations. Deservingness is based on the individual's ability to legitimize their experienced persecution or fear of it in their country of origin (or to prove they are a 'real refugee') and to demonstrate their willingness to fully integrate into their receiving country's community of value (or to prove they can become a 'good citizen'). What happens, however, as the asylum seeker is increasingly portrayed as a bogus, fraudulent migrant, as well as an economic burden, incapable and/or unwilling to quickly ascend the steps of autonomy?

\section{Italian asylum system during and after the European 'refugee crisis'}

Since its inception, the asylum system in Italy has been disorganized and focused on emergencies, pressured by contradictory needs both to control irregular migration and to protect refugees. Compared to other European countries, Italy's number of asylum seekers has remained objectively low over the past two decades (Italy received only 276,851 applications between 1990 and 2009; see Ministry of the Interior 2019). The reception system's capacity has long been undersized, too, even when including the collective detention centers and the System for the Protection of Asylum Seekers, and Refugees (Sistema di Protezione per Richiedenti Asilo e Rifugiati, Sprar). Institutionalized in 2002 and inspired by initiatives during the Balkan Wars, the System operates on the holistic idea of embedding reception and social integration through engagement with local communities (Marchetti 2016: 128).

Generally speaking, Italy faced the so-called 'refugee crisis' with a fragile, fragmented reception infrastructure and a prolonged determination procedure. Between 2014 and 2016, several factors had contributed to the perception that a crisis was underway - or rather, that Italy was in crisis regarding its inability to cope with the arrival of massive unscheduled flows. First, the increase of unplanned arrivals in the Central Mediterranean intensified until the end of 2016. Over the three-year period, 505,378 migrants disembarked in Italy, almost double the number of all migrants who had arrived by sea during the previous decade (from 2004-2013 there were 248,859 migrants). Second, due to the Dublin Regulation and the European Agenda on Migration, ${ }^{2}$ Italy had become a kind of 'trap.' Between 2014 and 2015, many migrants who had arrived in Italy later applied for asylum in other EU countries without having been identified and fingerprinted upon their disembarkation (Fontanari 2018). Following the implementation of the European Agenda and the hotspot approach in mid-2015, however, almost all the migrants who arrived in Italy were fingerprinted and thereby assigned 
to Italy. Refusing to adopt a strict, expulsive regime, Italy continued to consider the migrants as potential refugees rather than irregular economic migrants, facilitating their access to an international protection procedure. The number of asylum seekers in Italy subsequently soared from 241,752 between 2005 and 2014 to 340,323 between 2015 and $2017 .^{3}$ Thirdly, this surge, combined with Italy's legal obligation to meet quality standards (Directive 2013/33/EU, implemented in Italy by Legislative Decree No. 142 of 2015), prompted Italy to substantially expand the overall capacity of its reception system from about 22 thousand facilities in 2013 to over 190 thousand by 2017. Established after the Mare Nostrum Operation in 2013, ${ }^{4}$ emergency spaces within centers for asylum seekers accounted for much of this growth.

These developments greatly influenced the collective imagination's construction of a crisis, as did the greater visibility of migrants in many municipalities, and the misperception that reception costs diminished funding for other policies (in truth, a distribution plan made possible a fair, widespread distribution of migrants across all municipalities and only one in four municipalities was affected by reception-related projects). ${ }^{5}$ Additionally, many migrants who arrived in Italy during the three-year period did not originate from countries traditionally considered to be 'refugee producing,' such as: Nigeria, Guinea, the Ivory Coast, Mali, Pakistan, and Bangladesh. Many applications were thus labelled as manifestly unfounded (e.g. Tunisian) and/or received a rather low overall recognition rate: over the past three years, the aforementioned nationalities have obtained international protection at an average of between $2 \%$ and $16 \%$, even though the same nationalities have been recognized as needing humanitarian protection in $15 \%$ to $27 \%$ of cases (Ministry of the Interior 2019).

Different political parties and representatives of the last two Governments have employed these factors to promote a more restrictive, expulsive approach to Italian migration and asylum policies. This shift grew from both the need to fight international criminal networks of smugglers and traffickers and the assumption that Italy had become the primary destination for 'mixed migration,' attracting an inordinate number of economic migrants (Sharpe 2018). The legitimacy of the rescue policy - introduced after the tragic shipwrecks in the Channel of Sicily in 2013 - became precarious. Cooperation with Libya and Niger improved, as envisaged by the 2017 Memorandum of Understanding, which apportioned Italian aid for local border management capacities in areas surrounding the primary passageway used by Sub-Saharan migrants traveling to Italy through Libya. Simultaneously, the MinnitiOrlando Decree enacted more asylum restrictions, such as the openly discriminatory abolition of a degree of judgment in the asylum procedure. Despite these developments, wider protection - including international protection in terms of refugee status and subsidiary protection, as well as humanitarian protection - was preserved, allowing more than 100,000 asylum seekers to remain in Italy with a permit (Ministry of the Interior 2019) and to access the System for the Protection of Asylum Seekers and Refugees. 
In 2018, Salvini's Immigration and Security Decree further marginalized migrants by portraying potential asylum seekers as illegal aliens and abolishing humanitarian protection. ${ }^{6}$ Until then, migrants granted international and humanitarian protection could enter the System for the Protection of Asylum Seekers and Refugees and by then, had accounted for 30 percent of the system's beneficiaries. As a consequence of the abolition, Italy is now witnessing an increase in irregular migration and social marginality, as well as more general security problems. Between June 2018 and January 2019, having been denied any form of protection, around 45 thousand migrants became irregular, of which only five thousand were repatriated (contrary to the demagogic slogans of the Minister of the Interior, irregular migrants cannot be all forcibly repatriated to their countries of origin, particularly since Italy has no repatriation agreements with most of these countries).

Law 132/18 ultimately incapacitated the System for the Protection of Asylum Seekers and Refugees. Asylum seekers are now assigned to and isolated within extraordinary reception centers, where they receive minimal welfare services and no integration or language services. For asylum seekers, the collapse of the open reception and protection system drastically restricted the services available to them on their path of protection and social inclusion, exacerbating their growing vulnerability. The paradigm shift is thus almost complete: migrants traveling to Italy are no longer considered potential refugees but irregular migrants to be summarily rejected. The few asylum seekers who do arrive (numbering only 1,561 in the first five months of 2019, compared to 13,430, and 60,228 in the same period of 2018 and 2017 respectively) are not entitled to a wide set of rights accessed under ordinary reception. Instead, they are confined in extraordinary centers and subject to a regime of control and containment.

\section{Who is valuable in the Italian refugee regime?}

Building on this context, this paper uses the concepts of deservingness and the community of value to analyze the social construction of the un/worthy refugee. This paper draws on fieldwork conducted between October 2013 (with the beginning of the Mare Nostrum operation) and May 2019, both as a sociologist pursuing numerous qualitative research projects, and as a social worker directly involved in protection and reception activities in the city of Parma, as well as trainer for social workers across Italy. Ultimately, this paper aims to interrogate the policies meant to govern irregular migrants and asylum seekers, as well as the constructions of Italy's 'real refugees' and 'good citizens.'

\section{The regime of rights: Citizenship First}

Asylum policy in Italy transformed between 2013 and 2016. As mentioned above, migrants had previously enjoyed institutional and social openness. ${ }^{7}$ 
The State's Legislative Decree 142/2015 renounced the staircase model and provided asylum seekers - including those with a suspended legal status with access to the formal System for the Protection of Asylum Seekers and Refugees. Even though asylum seekers had to wait for their applications to be processed and to be fully acknowledged as 'real refugees,' they were not preemptively mistrusted by the government.

The System directly involved the local administrations that had the capacity to integrate refugee services into their local welfare systems and to supplement their services (particularly universal services like health) for the benefit of the entire community, regardless of migrant status. Moreover, the System followed a model that considered not only the material conditions of reception, but also the accelerated integration of migrants who would remain in Italy. Departing from the containment approach, this model affirms that asylum seekers are not fraudulent economic migrants until proven otherwise and that they ought to be treated as future citizens entitled to the rights and social opportunities of any other citizen as soon as possible (Ager $\&$ Strang 2008). Promoting a sense of security and stability in local communities, the System encouraged refugees' participation in their local community, as well as the development of integrated social networks among nationals, locals, and migrants (Catarci 2011).

Even if undersized, the System aspired to overcome the risks and avoid the distortions of an emergency approach, where asylum seekers were differentiated from refugees, and where only the most deserving could hope to settle. The System began enlarging its capacity for migrants, which grew from 3,000 in 2013 to around 24,000 by the end of 2016 . According to a national allocation plan, first issued in July 2014 and updated in October 2016, ${ }^{8}$ all 8,000 Italian municipalities shared reception responsibilities based on established quotas $(2.5$ migrants per thousand in general; 1.5 in metropolitan areas). Furthermore, while it was decided not to make the System for the protection mandatory for all local authorities, the updated plan laid out a strategy to increase quotas for municipalities facing higher migrant populations.

This regime of rights echoes the Housing First model for homeless populations as applied in Canada or New York, which offers chronically homeless people immediate access to scattered-site permanent apartments without sobriety or treatment prerequisites (Johnsen \& Teixeira 2010). In the context of asylum seekers, the concept of Citizenship First might be introduced. Here, it is not just a matter of housing, but one of fundamental rights. It is a matter of whether people must demonstrate that they are 'good' enough to deserve them.

\section{The regime of deservingness: disciplining access to the community of value}

As mentioned earlier, the regime of rights did not become the rule, despite institutional support. The wave of humanitarian compassion following the October 2013 shipwrecks quickly dissipated and a different regime emerged 
between 2015 and 2016. Though irregular migrants were still considered potential refugees and therefore afforded standard asylum procedure and reception, their moral status became more precarious. The regime of rights evolved into one of deservingness, increasingly demanding that migrants justify their presence in Italy and take responsibility for the alleged burden they placed on the economy and welfare system. On both national and local levels, reception began emphasizing how asylum seekers ought to behave for greater acceptance and integration. The persecution they faced in their countries of origin grew less relevant than the events and attitudes in the receiving country. The number of asylum seekers who received international protection declined and, while a significant number of migrants continued to receive humanitarian protection, they did so with greater juridical, moral, and social limitations.

Under these conditions, volunteering projects involving asylum seekers became more common as a way to: demonstrate the migrants' willingness to join the community of value, express their gratitude towards Italian society and institutions, and reciprocate for their reception and assistance. Though the 2017 Minniti-Orlando Decree explicitly invited Prefectures to promote 'any useful initiative to implement the use of asylum seekers, on a voluntary basis, in activities of social utility, ${ }^{9}$ (Testo coordinato del decreto-legge 2017) this trend had already begun two years prior. Before its application to asylum seekers, such community service programs had been mandated by courts as an alternative to prison for minor offenders or offered by municipal social services to help unemployed individuals build skills. The pressure on asylum seekers to participate in these programs grew so strong that, in many situations, it became difficult to discern whether their participation was voluntary or compulsory. Moreover, in many cases, the services migrants were called to perform included collecting garbage in city parks and streets, maintaining public green areas, and even cemeteries. Not only were such jobs highly visible, but they were jobs that traditionally entailed remuneration. The aggressive, large-scale promotion of these activities - to potentially all of the 150,000 asylum seekers present in Italy during this time - threatened a very delicate balance in the already fragile and precarious labor market, worsening the conflict between 'failed citizens' (Italians) and 'non-citizens' (migrants).

Social expectations for asylum seekers included their spontaneous and sincere commitment to these programs. Failure to meet these expectations prompted moral judgment and disapproval. For example, in the province of Piacenza, asylum seekers were dancing with social workers at a party. The province's major responded: 'if they have time to have fun, they also have it to keep to their commitment' (Redazione 2018) or to keep the voluntary pact they signed with the municipality. ${ }^{10}$ Despite other criticism, as well, it was revealed that asylum seekers later broke their agreements only after signing work contracts that prevented them from upholding them (I richiedenti asilo 2019). Another mayor of a small city in the province of Brescia 
publicly noted the absence of asylum seekers in these 'voluntary' programs, telling the local newspaper: 'everyone has duties, as well as rights. It is necessary that in the cooperatives managing their reception, someone explains to them that something must be done to repay the hospitality they receive' (Di Stefano 2018). For local asylum seekers, however, their refusal to cooperate stemmed from issues like the absence of hot water or internet access in their accommodations. When some migrants accused the mayor of making insufficient efforts to ameliorate such problems, the mayor replied that despite his efforts, 'the commission decided based on the possession or lack of certain requirements' (ibid.).

The Brescia episode illustrates several points. Local administrations and social workers often view community service as a way for asylum seekers to reciprocate for their reception and assistance. In contrast, asylum seekers understand that their good behavior and engagement in voluntary projects deserve compensation, if not with a salary, then with greater protection. In partial response, the Commissions and Courts issued humanitarian protection based not on migrants' persecution in their countries of origin, but on their 'successful integration' into Italy, as demonstrated by employment or a history of performing voluntary activities. ${ }^{11}$ Mario Morcone, the then-chief of the Civil Liberties and Immigration Department proposed in 2016 to introduce a reward mechanism: "who shows good will and ability to fit into our social context could get more attention. Humanitarian protection, which is currently given for reasons of vulnerability to minors and vulnerable people, could be used in this sense' (Il prefetto Morcone 2016). This is the same reward mechanism proposed by the Mayor of Bergamo for the aforementioned Integration Academy's asylum seekers. This connection between behavior and status, as well as the regime of deservingness' usurpation of the regime of rights is a relatively recent development towards an adoption of the staircase model.

The urge to adopt a scalar, reward-and-punishment model to better discipline individuals and educate them on the community of value had been observed in reception proceedings even before the 'refugee crisis.' Social workers tended to 'punish' asylum seekers who refused to participate in their suggested activities and to 'reward' those who agreed to it, granting them more housing and employment opportunities. One social worker describes these implicit codes of conduct in the following way:

The ways in which we decided, for example, who to offer the possibility of a work placement were based on a reward logic.... The criteria we decided on were: the degree of participation in domestic life and the attitude within the center; the reliability of the guest; the level of knowledge of the Italian language, also measured by the frequency of the Italian course that some guests attended outside of the structure; previous professional skills and aspirations declared during individual interviews.

(Biffi 2017:148-9) 
Writing specifically on women asylum seekers in a Sicilian reception center, another researcher explains:

Within the centers, the control of women takes the form of a series of practices and techniques that aim, in fact, to educate them towards behaviors considered 'just,' concerning their being women capable of caring for themselves and for children.... Maaza [an Ethiopian asylum seeker, AN] bathed her baby every morning under the watchful eye of social workers in a room set up specifically for these activities. She also received binding suggestions regarding the methods of care: how much and how to breastfeed, how to treat and keep clean her own body and that of the child.

(Pinelli 2011: 170)

The regime of deservingness emphasizes that discipline, education, and rules for behavior contribute not only to successful social integration and acceptance, but also to greater access to scarce opportunities. After 2016 the expectation that these scarce resources could also include a juridical reward (namely humanitarian protection) became more and more widespread among asylum seekers and social workers, and added emphasis on the disciplining impact of the deservingness regime.

\section{The regime of containment: dispossession without protection}

But what happens when good behavior is disentangled from welfare and juridical rewards? As explained earlier, since 2017, migrants' access to asylum procedure and protection have been significantly limited. Though treated with suspicion and mistrust, migrants are still expected to behave well and demonstrate their respect for Italian institutions and people, without any hope for a possible reward. The abolition of humanitarian protection affirms their despair. In 2017, the overall recognition rate of migrants was $41 \%$, with $25 \%$ among them receiving humanitarian protection; in 2018, these numbers lowered to an average of $33 \%$ and $21 \%$ respectively (overall recognition rate and humanitarian protection). Following the Immigration and Security Decree (October-December 2018), however, the recognition rate has fallen to 20\% and 3\% respectively (Ministry of the Interior 2019).

Yet, disciplinary pressures on migrants have not diminished but instead increased. The regime of deservingness has given way to one of containment. The regime of containment concerns itself with more than just surveillance and tracking: 'the Hotspot System contributes to enforce forms of containment through mobility that consists in controlling migration by obstructing, decelerating, and troubling migrants' geographies - more than in fully blocking them' (Tazzioli 2017: 2764).

Though Tazzioli's ethnography focuses on the circumstances around Europe's external borders, it also sheds light on the situation in Italy. 
Containment seems less about mobility and more about 'training' asylum seekers for a life of displacement, as they likely will fail to obtain protection and will not return to their country of origin. The containment regime thus dispossesses asylum seekers of their subjectivity.

The Prefect of Florence's 2018 memos to managers of local reception centers demonstrate the containment regime's operations. In addition to introducing strict curfews (between $8 \mathrm{pm}$ and $8 \mathrm{am}$ ), the memos instructed social workers to open any deliveries of goods purchased online 'both for security reasons and to verify that the purchases are compatible with the economic situation declared by the guest' (Simoni 2018). Even bicycles have become objects of control: if an asylum seeker's bicycle is not one supplied by the reception center, social workers must clarify with the individual how their bicycle was procured. As at Bergamo's Integration Academy, the prefectural instructions do not distinguish between weekdays and holidays and do little to encourage social networking: 'in the absence of any reasoning that explains such a restrictive approach, those who drafted the text inevitably take on the burden of proving that ... 'guests' must not be part of the night life of the city' (Simoni 2018).

Under the regime of containment, such restrictions are the norm. Furthermore, following the Immigration and Security Decree, budget cuts have led to the reduction of professional workers involved in reception and assistance. On average, one social worker assumes responsibility for 50 asylum seekers:

The operator may follow each guest for ten minutes a day, including signatures, goods distribution, food, pocket money, linguistic, and cultural mediation. Individual assessment with social workers corresponds to ten hours per week for every 50 people: it means 1.7 minutes a day. Transportation? The logic of the tenders is that people do not need to move: 12 annual journeys of a maximum of 30 kilometers each.

(Accoglienza 2019)

Large centers give asylum seekers no opportunities to go out in the evening, to explore the city, or to even attend an Italian language course. With fewer social workers, the regime has assumed even tighter control, further limiting integration efforts. In fact, with this politics of suspicion, there seems little need to invest in integration: there is no longer any ladder, or any 'staircase of transition,' to climb.

\section{Conclusions Social workers and asylum seekers as actors of contentious politics}

I am very worried about the future of those who have accepted to be part of the Academy. The last time I saw the guys who joined, they seemed more closed and alone. They suffer because they can no longer attend the mosque 
and the markets, nor call home more frequently. But they hold on. They are afraid of expressing their unease because they fear being excluded from the project, especially now that the Salvini propaganda is terrifying.

(D’Aprile 2018)

The above passage was shared by an insider at the Integration Academy, who describes the asylum seekers' feelings of isolation and fear amidst a radically changed and increasingly xenophobic socio-political context. This fraught climate affects social workers, as well, as they fear losing employment. Under the new asylum system, an estimated 18,000 will be fired. Moreover, regardless of their present employment status, social perceptions have turned against them. In addition to social workers, volunteers, activists, cooperatives, solidarity movements, and NGOs are represented as internal enemies to the movement of 'Italians first' (Fontanari \& Borri 2017; Zamponi 2017).

In Italy, the role of civil society in asylum and reception policy has always been peculiar. Civil society led the organization of 'welfare from below' (Belloni 2016) and the institutionalization of a multi-level national asylum system (Marchetti 2016; Campomori \& Caponio 2017). It was also a key player in enhancing the principles of horizontal subsidiarity. Throughout these processes, social workers were conflated with volunteers and activists. Only in recent years has professionalization occurred, allowing workers to better acquire professional skills and roles comparable to those in other sectors of welfare. Yet, with professionalization also come the power structures and asymmetrical dynamics endemic to social work (Harrell-Bond 1986).

The negative turn of the definition of refugee, which increasingly echoes the definition of irregular economic migrant, has had a number of detrimental effects. At the same time, however, it opens the field for new forms of contentious politics, where 'adopting a contentious politics perspective [can] focus attention on interactions among protesters, claim makers and their objects, governments' (Ilker et al. 2016: 536). Furthermore, critical citizenship studies have drawn attention to processes of claiming rights. Isin (2008), for example, explains how feminist and other civil rights movements transformed subjects into legitimate claimants of rights through various acts - demonstrations, protests, occupations, and performances - that were symbolically and materially constitutive of citizenship.

As it stands, groups may be able to challenge Italy's asylum policy at the local level in a battleground (Ambrosini 2018) upon which different actors engage and pro-immigrant actors are a counterweight to xenophobic movements, supporting migrants' interests. Above all, however, social workers and civil society together with asylum seekers, refugees, and (irregular) migrants must cooperate in actions and claims from a place of symmetry and parity, emphasizing their similarities within a diverse set of intercultural political relations (Remotti 2019). Social workers must not only opt out the regime of containment and their associated positions of power but they must 
also avoid perpetuating a regime of deservingness, along with its disciplinary, social, and moral practices to shape 'good' individuals. The battleground is open for citizenship struggles and the acknowledgement of both migrants' and social workers' subjectivity.

\section{Notes}

1 See, for example, Lafleur and Mescoli, 2018 on Italian migrants in Belgium.

2 https:/ec.europa.eu/home-affairs/what-we-do/policies/european-agenda-migration en (accessed: July 10, 2019).

3 In this case, the three-year period considered includes 2017 when, although the decline in arrivals began, the imposition of applying for asylum in Italy made the balance between the number of requests and the number of migrants landed positive $(130,119$ vs. 119,310$)$.

4 The Mare Nostrum Operation was launched by the Italian Government on October 18, 2013, as a military and humanitarian operation aimed at tackling the humanitarian emergency in the Strait of Sicily, due to the dramatic increase in migration flows and deaths at sea. The Operation ended on October 31, 2014, coinciding with the start of the new operation called Triton (Frontex). Operation Mare Nostrum had the twofold purpose of safeguarding human life at sea, and bringing to justice human traffickers and migrant smugglers. Mare Nostrum carried out 421 missions, in which more than 100,250 migrants were rescued.

5 The expense for the operations of relief, health, reception, and education was estimated at 4.3 billion $(0.25 \%$ of GDP) for 2017, net of EU contributions; the expenditure forecast to be incurred in 2018 was between 4.6 and 5 billion which, even after deducting the EU contributions, leads to an increase of between $0.02 \%$ and $0.04 \%$ of GDP compared to the 2017 expenditure (Ministry of Economy and Finance 2018: 55-6). From this point of view the figure showing that in 2017 foreign taxpayers paid taxes on personal income equal to 3.3 billion euro matters little. It added to other entry items attributable to foreign nationals which have ensured a revenue in the State coffers equal to 19.2 billion Euros. Compared with 17.5 billion of public spending dedicated to immigrants $(2.1 \%$ of all national public expenditure), they create a surplus in the state budget between 1.7 and 3 billion euro (IDOS, Confronti 2018).

6 According to Art. 5 Par. 6 of the Consolidated Law 286/98 (which finally implemented the 'Constitutional asylum' provided for by Art. 10, Par. 3 of the Constitution, under which Italy must grant asylum to all those who in the countries of origin are not granted the fundamental rights and freedoms recognized by the Constitution), the Police could grant a residence permit for humanitarian reasons to foreign citizens, such as unaccompanied foreign minors strongly traumatized by the journey, women with children who suffered torture and/or detention in Libya, those whose human dignity was violated, or people fleeing emergencies such as conflicts, natural disasters or other particularly serious events in countries outside the European Union.

7 For example, episodes of social and institutional exclusion happened in different regions (see Marchetti forthcoming). Moreover, the model I'm describing here was practically limited by the capacity of the ordinary system, so that extraordinary reception centers - with a different approach - prevailed: in 2016 they offered 137,218 places compared to 23,822 in the System for the protection of Asylum Seekers and Refugees (Ministry of Economy and Finance 2018: 70)

8 Ministry of the Interior Directive of October 11, 2016 'Regole per l'avvio di un sistema di ripartizione graduale e sostenibile dei richiedenti asilo e 
rifugiati sul territorio nazionale,' www.sprar.it/wp-content/uploads/2017/02/m inistrointerno11ottobre2016.pdf (accessed: July 10, 2019).

9 Testo coordinato del decreto-legge February 17, 2017, n. 1, www.sprar.it/wp-con tent/uploads/2017/01/immigrazione-il-testo-coordinato-del-decreto-minniti.pdf (accessed July 10, 2019).

10 All translations from Italian are mine.

11 See also the Judgment of the Civil Cassation n. 4455 of February 2018.

\section{References}

Accoglienza (2019). 'Nei nuovi bandi via psicologi e trasporti tagliati,' Vita. February 13. Available at: www.vita.it/it/article/2019/02/13/accoglienza-nei-nuovi-bandi-via -psicologi-e-trasporti-tagliati/150670/

Ager, A. \& Strang, A. (2008). 'Understanding integration: A conceptual framework,' Journal of Refugee Studies 21(2), pp. 166-191.

Ambrosini, M. (2018). Irregular Immigration in Southern Europe. Actors, Dynamics and Governance. Basingstoke: Palgrave Macmillan.

Anderson, B. (2012). 'What does "the migrant" tell us about the (good) citizen?' Centre on Migration, Policy and Society, Working Paper no. 94. University of Oxford.

Anderson, B. (2013). Us $\&$ them? The Dangerous Politics of Immigration Control. Oxford: Oxford University Press.

Belloni, M. (2016). 'Learning how to squat: Cooperation and conflict between refugees and natives in Rome, 'Journal of Refugee Studies, pp. 1-22.

Biffi, D. (2017). 'Fra controllo e abbandono. Etnografia da un centro di accoglienza,' in Marchetti, C. \& Pinelli, B. (eds). Confini d'Europa. Modelli di controllo e inclusioni informali. Milano: Edizioni Libreria Cortina.

Bonilla-Silva, E. (2006). Racism without racists. Color-blind racism and the Persistence of Racial Inequality in the United States, 2nd edn. Lanham: Rowman \& Littlefield Publishers, Inc.

Campomori, F. \& Caponio T. (2017). 'Immigrant integration policymaking in Italy: regional policies in a multi-level governance perspective,' International Review of Administrative Sciences 83(2), pp. 303-321.

Catarci, M. (2011). L'integrazione dei rifugiati. Formazione e inclusione nelle rappresentazioni degli operatori locali. Milano: Franco Angeli.

D'Aprile, F. (2018). “"Tutti la lodano, ma l'Accademia per i migranti di Bergamo distrugge le identità anziché integrare," parla un operatore,' TPI News, December 17. Available at: www.tpi.it/2018/12/17/accademia-integrazione-bergamo/

Dhaliwal, S. \& Forkert, K. (2016). 'Deserving and undeserving migrants,' Soundings: A Journal of Politics and Culture 61, pp. 49-61.

Di Stefano, D. (2018). 'Zone, i richiedenti asilo disertano la pulizia dei sentieri. Ad aiutare il sindaco solo gli italiani,' Il Primato Nazionale. Quotidiano Sovranista, June 18. Available at: www.ilprimatonazionale.it/approfondimenti/zone-i-richiedenti-a silo-disertano-la-pulizia-dei-sentieri-ad-aiutare-il-sindaco-solo-gli-italiani-87615/

Duffield, M. (2001). Global Governance and the New Wars: The Merging of Development and Security. Chicago: University of Chicago Press.

European Union (1992). Council Resolution of 30 November 1992 on Manifestly Unfounded Applications for Asylum ('London Resolution'), Council of the European Union, November 30. Available at: www.refworld.org/docid/3f86bbcc4.html 
Fassin, D. (2005). 'Compassion and repression: The moral economy of immigration policies in France,' Cultural Anthropology 20(3), pp. 362-387.

Fontanari, E. (2018). Lives in Transit: An Ethnographic Study of Refugees' Subjectivity across European Borders. Abingdon: Routledge.

Fontanari, E. \& Borri, G. (2017). 'Introduction: Civil society on the edge: Actions in support and against refugees in Italy and Germany,' Mondi Migranti 3, pp. 23-51.

Harrell-Bond, B. E. (1986). Imposing Aid: Emergency Assistance to Refugees. Oxford University Press: Oxford.

Home Office (1999). Consultation Paper on the Integration of Recognised Refugees in the UK. Croydon: IND Home Office.

'I richiedenti asilo ballano ma non hanno tempo per i lavori socialmente utili' (2019). Il Piacenza, 23 August. Available at: www.ilpiacenza.it/cronaca/i-richiedenti-asilo-ba llano-ma-non-hanno-tempo-per-i-lavori-socialmente-utili.html

IDOS, Confronti (2018). Dossier statistico immigrazione 2018. Roma: IDOS Centro Studi e Ricerche.

Ilker, A., Rygiel, K., \& Stierl, M. (2016). 'Introduction: The contentious politics of refugee and migrant protest and solidarity movements: Remaking citizenship from the margins,' Citizenship Studies 20(5), pp. 527-544.

Il prefettoMorcone (2016). 'Affidiamo ai migranti lavori utili nelle città,' Il Messaggero, August, 18. Available at: www.ilmessaggero.it/primopiano/cronaca/morcone_p refetto_lavori_utili_migranti-1917031.html

Isin, E. F. (2008). 'Theorizing acts of citizenship,' in Isin, E. F. \& Nielsen, G. M. (eds) Acts of Citizenship. London: Zed Books, pp. 15-43.

Johnsen, S. \& Teixeira, L. (2010). 'Staircases, elevators and cycles of change: Housing First and other housing models for people with complex support needs,' Crisis, July. University of York. Available at: www.crisis.org.uk/media/20498/staircases_ elevators_and_cycles_of_change_es2010.pdf

Lafleur, J.-M. \& Mescoli, E. (2018). 'Creating undocumented EU migrants through welfare: A conceptualization of undeserving and precarious citizenship,' Sociology 52(3), pp. 480-496.

Malkki, L. H. (1996). 'Speechless emissaries: Refugees, humanitarianism, and dehistoricization,' Cultural Anthropology 11(3), pp. 377-404.

Marchetti, C. (2016). 'Le sfide dell'accoglienza. Passato e presente dei sistemi istituzionali di accoglienza di richiedenti asilo e rifugiati in Italia,' Meridiana. Rivista di storia e scienze sociali 86, pp. 121-143.

Marchetti, C. (forthcoming). 'Cities of exclusion: Are local authorities refusing asylum seekers?' in Ambrosini, M., Cinalli, M., \& Jacobson, D. (eds) Migration, Borders and Citizenship - Between Policy and Public Spheres. London: Palgrave Macmillan.

Ministry of Economy and Finance (2018). Documento di economia e finanza 2018, April 26. Available at: www.dt.mef.gov.it/export/sites/sitodt/modules/documenti_it/ana lisi_progammazione/documenti_programmatici/def_2018/DEF_2018_-_Sez.1_-Pro gramma_di_Stabilitx.pdf

Ministry of the Interior (2019). Quaderno statistico dal 1990 al 2018. Available at: www.libertaciviliimmigrazione.dlci.interno.gov.it/sites/default/files/allegati/qua derno_statistico_per_gli_anni_1990-2018.pdf

Oliveri, F. (2014). 'Us \& them? The dangerous politics of immigration control,' Space and Polity 18(3), pp. 1-4. 
Olsson, L.-E. \& Nordfeldt, M. (2008). 'Homelessness and the tertiary welfare system in Sweden - The role of the welfare state and non-profit sector,' European Journal of Homelessness (2), pp. 157-173.

Ong, A. (2003). Buddha is Hiding: Refugees, Citizenship, the New America. Oakland: University of California Press.

Pinelli, B. (2011). 'Attraversando il Mediterraneo. Il "sistema campo" in Italia: Violenza e soggettività nelle esperienze delle donne,' Lares. Quadrimestrale di studi demoetnoantropologici 77(1), pp. 159-179.

Pupavac, V. (2006). 'Refugees in the "sick role": Stereotyping refugees and eroding refugee rights,' New Issues in Refugee Research, UNHCR Working Paper, 128.

Redazione (2018). 'I richiedenti asilo ballano ma non hanno tempo per i lavori socialmente utili,' Il Piacenza, August 23. Available at: www.ilpiacenza.it/cronaca/ i-richiedenti-asilo-ballano-ma-non-hanno-tempo-per-i-lavori-socialmente-utili.html

Remotti, F. (2019). Somiglianze. Una via per la convivenza. Roma-Bari: Laterza.

Rose, N. (1999). Powers of Freedom: Reframing Political Thought. Cambridge: Cambridge University Press.

Sahlin, I. (2005). 'The staircase of transition: Survival through failure,' Innovation, European Journal of Social Research 18(2), pp. 115-135.

Sales, R. (2002). 'The deserving and the undeserving? Refugees, asylum seekers and welfare in Britain,' Critical Social Policy 22, pp. 456-478.

Sharpe, M. (2018). 'Mixed up: International law and the meaning(s) of "mixed migration",' Refugee Survey Quarterly 37(1), pp. 116-138.

Simoni, A. (2018). 'Biking while black. Riflessioni a partire dalle recenti circolari del prefetto di Firenze,' Questione Giustizia, November 30. Available at: http:/ques tionegiustizia.it/articolo/biking-while-black-riflessioni-a-partire-dalle-recenti-circola ri-del-prefetto-di-firenze_30-11-2018.php

Tazzioli, M. (2017). 'Containment through mobility: Migrants' spatial disobediences and the reshaping of control through the hotspot system,' Journal of Ethnic and Migration Studies 44(16), pp. 2764-2779.

Testo coordinato del decreto-legge (2017). 'Immigrazione: il testo coordinato del decreto Minniti,' Gazzetta Ufficiale, February 17. No. 13 in serie generale no. 40. Available at: www.sprar.it/wp-content/uploads/2017/01/immigrazione-il-testo-coordina to-del-decreto-minniti.pdf

United Nations High Commissioner for Refugees (UNHCR) (1992). UNHCR's Position on Manifestly Unfounded Applications for Asylum. December 1, 3rd European Series (2), p. 397. Available at: www.refworld.org/docid/3ae6b31d83.html

Valentine Daniel, E. \& Knudsen, J. C. (1995). Mistrusting Refugees. Oakland: University of California Press.

Yoo, G. J. (2008). 'Immigrants and welfare: Policy constructions of deservingness,' Journal of Immigrant Eु Refugee Studies 6(4), pp. 490-507.

Zamponi, L. (2017). 'Practices of solidarity: Direct social action, politicisation and refugee solidarity activism in Italy,' Mondi Migranti 3, pp. 97-117. 


\title{
16 Christian charity as the last line of defense for migrants in Ventimiglia
}

\author{
Juan Pablo Aris Escarcena
}

\section{Introduction}

The migration 'crisis' in Europe has led to the reappearance of border controls within the European internal space established by the Schengen agreements and the European Union's (EU) Area of Freedom, Security and Justice. In several countries - France, Austria, or Switzerland border controls have been recently re-established. This decision was justified by invoking security reasons, including terrorism, and excessive migration presented as a threat to the stability and social order of European countries.

Expulsion strategies have been developed in several of the border areas. Hostile environments have been built using different techniques: prohibiting tents to prevent refugees from sleeping outdoors, banning food distributions, and prosecuting volunteers assisting migrants. In the extreme cases, such as that of Cedric Herrou, a French farmer who provided support to migrants in the border area between France and Italy, volunteers were convicted for 'crimes of solidarity' (Tazzioli \& Walters 2019).

In Ventimiglia - the closest Italian town to France on the coast - all of these techniques have been implemented. The border between Italy and France has become a hostile environment, a result of political measures of both states. However, the social influence of the Catholic Church has served as a last line of defense ${ }^{1}$ to curb the effects of the expulsion tactics.

This chapter analyzes how the governmental actions created a hostile environment in Ventimiglia, and how the cultural link with the Catholic value of charity ${ }^{2}$ has resulted in creating spaces of defense against persecution of migrants. It focuses on the forms of activism developed by 'Catholic organizations,' i.e. civil society voluntary organizations coordinated and led by local church or religious group. It does not refer to organizations based on the ecclesiastical hierarchy, but to those that arise from local interaction between citizens and the Catholic Church. The concept of charity is a multifaceted and complex concept. This chapter presents the practices that different organizations and actors have carried out motivated by charity. These experiences are the basis of the of the definition of charity given at the end 


\section{4}

J. P. Aris Escarcena

of the chapter. Likewise, the chapter reflects on the limits of the social definition of moral values, on their potentialities and risks.

This chapter is based on ethnographic fieldwork carried out in Ventimiglia between October and December 2017, as well as in June 2018. The research was carried out through participant observation of different civil society organizations. This ethnographic work is part of a larger research project ${ }^{3}$ based on multi-sited ethnography across different locations on the borders of the EU, such as Ceuta and Melilla (Spanish enclaves in North Africa), Calais (France), and Katsikas (Greece).

\section{The creation of a hostile environment: Ventimiglia}

The city of Ventimiglia is the closest Italian urban center to France on the Mediterranean Côte d'Azur. The city is located at the mouth of the valley of the Roya river, near to Menton, the first French city on the coast. The proximity to the border with France has always been a fundamental source of resources for the city, including border trade.

In 2011, this small city of 24,000 inhabitants became the main site for an enormous transformation in the EU policies for managing migratory flows. As Sabine Hess and Bernd Kasparek (2017) point out, the re-establishment of border controls within the Schengen Area by France on its border with Ventimiglia was the trigger for a political process that would eventually result in the modification of the Schengen Border Code (SBC) (European Union 2016). From 2013 onwards, a provision was included in the Schengen Border Code allowing the member States of the EU to re-establish border controls in the Schengen area. This provision was reinforced in 2016, with the inclusion of a chapter dedicated to the conditions and modalities for the re-establishment of controls at the internal borders of the Schengen area. It is noteworthy that the recent $\mathrm{SBC}$ amendment extended the period allowing member states to re-establish border controls for up to six months (in 30day renewable tranches) in ordinary circumstances, and up to two years in extraordinary circumstances (Chapter II, Art. 25). The question of how an extraordinary situation is defined is one of the most controversial points of the European normative provisions. An extraordinary situation is one that poses a serious and unforeseen threat to the social order of a member state, but it is the states themselves who evaluate the situations and declare unilaterally that a situation is extraordinary.

Due to the prolonged closure of the borders in Ventimiglia by the French government in 2011 (ASAFFRON Association 2017) and subsequently after the 2015 attacks in Paris, Ventimiglia became a key place on the migratory route to the countries of Central and Northern Europe. In this small city, migrants who were trying to reach France without the necessary administrative permits were waiting for an opportunity to enter the country.

In Italy, the political response to the re-establishment of border controls by France has been very controversial (for a broader understanding of the 
situation in Italy see Chapter 15 in this volume). The policies of local and state authorities have been in constant tension between the quest to control migration and offer a solution and the quest to avoid the presence of large groups of migrants in the territory of the border city. The result was the creation of a hostile environment, where the presence of migrants was not welcomed and attempts were made to encourage the disappearance of migrants from the area with ad hoc political measures. This has been done through three processes: 1) denial of housing spaces; 2) prohibition of food distributions; and 3) expulsion from the territory of the city.

These political stances were rejected by civil society, including Catholic organizations, which played a fundamental role in the coordination of humanitarian assistance and the defense of migrants' rights.

\section{The denial of housing spaces}

In 2015, just after the borders were newly closed by the French state, migrants who were prevented by the police from entering the French territory did not settle in Ventimiglia, but remained as close as possible to the border crossing. Thus, the breakwaters and a small pine forest in the town of Balzi Rossi became de facto a makeshift shelter for the migrants; the group of migrants became progressively large, averaging 100 and reaching approximately 200 people at its peak.

The camp in Balzi Rossi was set up under the San Ludovico bridge. Migrants piled old tents and other substandard housing to protect themselves from the cold and rain next to a tourist parking lot. The camp was run by the migrants themselves in collaboration with activists from the No Borders group, a network of local organizations defined by its 'struggle alongside with migrants and asylum seekers for freedom of movement, for the freedom for all to stay in the place, which they have chosen, against repression and the many controls which multiply the borders everywhere in all countries' (Noborder Network 2004; see also Alldred 2003; Burridge 2010). This camp was active until 30 September 2015, when the Italian police bulldozed the makeshift shelters and migrants' belongings: tents, sleeping bags, mattresses, and blankets. Afterwards the migrants left the border enclave and Ventimiglia became the place from which to undertake the increasingly risky border-crossing into France.

For a few months, the migrants in Ventimiglia were dispersed throughout the city, sleeping in parks, streets, and in the vicinity of the train station the arrival point for most migrants seeking to continue their journey to France - where the government decided to set up emergency facilities, including a set of military tents managed by the Italian Red Cross.

In May 2016, following the visit of the then Minister of Interior, Angelino Alfano, the emergency facilities were closed, and the Red Cross was forbidden to distribute food and hygiene kits in the vicinity of the station. The government declared it wanted to seek reception systems for migrants in the 
cities of Milan and San Remo, thus preventing the growth of the migrant population in Ventimiglia. However, the result was that hundreds of people were again sleeping outdoors albeit in different parts of the city.

\section{The opening of the Delle Gianchette Church}

On May 31, 2016, the parish priest of the Church of Sant'Antonio Delle Gianchette - Fr. Rito Álvarez - decided to offer the church as a shelter for migrants who had nowhere else to go. This decision was presented as a response to the call of Pope Francis that parishes and communities welcomed refugees (Faiola \& Birnbaum 2015).

In one month, about 1,000 migrants sought shelter in the church, which became a place of reference also for the volunteers willing to show solidary with migrants and assist them. The volunteer mobilization was enormous, first through groups of parishioners of the Delle Gianchette Church and neighborhood residents and later from other parts of Italy and France. Many of the parishioners were descendants of Calabrian migrants or were migrants themselves (on the importance of migration memory see Chapter 2 in this volume). Despite the outpouring of solidarity and volunteer assistance, the prefecture forced the Church to close its doors and expel the migrants residing there.

It should be noted that the opening of the Delle Gianchette Church greatly impacted volunteer activism. Many volunteers became involved in providing assistance to the migrants. Antonio, a retired cook who frequently collaborated with the church and with Caritas said: 'I came to cook here from time to time, and one day we had to cook for 300 people. Now I come every day to cook for the migrants and for all those who need it.'

The support of the parish for the migrant community was a positive reinforcement for the local population, who maintained an attitude of solidarity with the migrants in spite of the potential difficulties that the incorporation of 1,000 people in a working-class neighborhood of Ventimiglia could pose for their daily lives. The positive effect of the parish leadership on the local participation was confirmed when, more than a year later, the parish stopped welcoming migrants and many of the people who were mobilized to support the project abandoned their involvement with the migrant community.

It is noteworthy how the support of migrants by the local parish prevented the expulsion of individual volunteers and non-religious organizations assisting migrants in Ventimiglia. Even groups with distant positions from the Catholic Church, such as the No Borders organization, continued to work in the city, in stark contrast with the criminalization suffered in Balzi Rossi or in the Roya Valley (Giliberti 2018). The case of the renowned French activist, Cédric Herrou, who started his activism by moving vulnerable migrants from the Delle Gianchette Church to his farm in Breil-sur-Roya is an example of criminalization of assistance to migrants. Herrou was accused by the 
French government of smuggling migrants. However, in 2018, the Constitutional Court of France affirmed that his humanitarian aid on French territory was an expression of the constitutional principle of fraternity and could therefore not be considered a crime. However, assisting migrants to cross the border or to circulate within the territory of the country continues to be the subject of French judicial scrutiny. On the contrary, the people involved in the church reception project have never been sanctioned in any way. The administrative measure foglio di via, by which a citizen can be expelled from a municipality for reasons of public safety and prohibited from returning to that municipality for three years was often used instead against other associations, but never against those affiliated with the church.

\section{The reaction of public authorities}

Reception in the church proved to be a very effective advocacy strategy. In addition to the humanitarian assistance, the social and cultural capital that the local parish was able to mobilize in defense of this project forced the public administration to revise its migration management policies. The opening of the church to migrants quickly prompted the state authorities, namely the Prefecture of Imperia, and the local authorities to contact each other and begin negotiations. At first, the public authorities demanded that the church reception project be stopped on the grounds that the structure did not have the appropriate characteristics to carry out reception under dignified conditions. Arguably due to the strong social support for the project, the parish refused to comply with such request until a structure that could accommodate migrants was established. This forced the authorities to open a reception complex, the Parco Roya, a new camp composed of containers and military tents, about five kilometers away from the Delle Gianchette Church.

The Parco Roya was established in June 2016, and it was again managed by the Italian Red Cross. However, the Delle Gianchette Church continued to welcome families, women, and children, as the camp did not have adequate space for everybody. In February 2017, the camp was temporarily closed due to an accidental fire, and the few people who lived there were moved. Upon its reopening in March of the same year, the internal structure of the camp and its policies were changed: entrance was conditional upon a fingerprint screening that was checked against the Eurodac database (European Union 2013). The database is used to determine which European country is responsible for the asylum application of a particular migrant. According to the Dublin agreement, migrants must request asylum in the first country of arrival within the EU or be returned (European Union 2000).

Faced with these regulations, many migrants refused to be sheltered in Parco Roya. The required controls clashed with their plans to migrate to other European countries (and to present their asylum application there). As a migrant from South Sudan pointed out in an interview: 'We don't want to 
stay in Italy, we come from a British colony and we speak English since we're children.... Why do we have to stay in Italy? It's one of the things I don't understand about Europe.'

The consequence was the birth of an informal camp under the bridge of the SS20 motorway, in the same street (Via Tenda) where the Delle Gianchette Church is located. These campsites sprung up before, even when the church welcomed all migrants, but they were an exception and they included isolated tents located either on the banks of the river or under the railway bridge. The church was also involved in assisting migrants who were beginning to live outdoors. The police prevented any type of construction, therefore migrants improvised and spread blankets on the damp ground, people slept clinging together for warmth, bonfires were kept lit next to their heads to fight the cold and scare rats, mountain-cold water was used for personal cleaning. Insecurity and the fear of being deported was part of everyday life under the bridge.

State and local authorities saw this situation as an obstacle to their efforts to control and move migrants to the outskirts of the city. Again, the church was required to stop providing assistance to migrants, and once again it argued that families, women, and children could not be left homeless. However, the authorities hastened the opening of dedicated structures for women and minors in Parco Roya, and on August 14, 2017, the Sant'Antonio Delle Gianchette Church closed its doors ending a 440-day long reception project. Since then, the church has repeatedly welcomed migrants, but only on ad hoc basis to prevent them from staying outdoors during storms; it has never again been used as a stable shelter. And in front of it, hundreds of migrants continued to live outdoors for an entire year until they were expelled in the spring of 2018. Some migrants went to Parco Roya, but many others slept in the streets and on the Roya River banks.

\section{The heritage of the Delle Gianchette Church}

In spite of the official end of the church's project, an informal network of volunteers emerged and sheltered vulnerable migrants in their own homes. These volunteers had met while participating in the church activities and were aware of the limitations of the official reception system and the dangers migrants faced both in the Parco Roya and in the informal camps. This newly emerged network sought alternative housing for the most vulnerable, mainly mothers with their children, and young women at risk of falling into the hands of traffickers and prostitution networks. Manuela, a volunteer in this network, explained to me that:

They had formed a wonderful group of people who took responsibility for protecting people. Whatever happens (referring to the legal problems that volunteers could face if the police found them sheltering 
families or, above all, unaccompanied minors) we cannot allow innocent people to sleep there, under a bridge or camp without any protection.

This historical analysis helps to show the strength and potential of the projects led by Catholic organizations in Ventimiglia and beyond. During the fieldwork carried out in Palermo in 2018, I had the opportunity to observe the fundamental difference the support of Christian organizations - such as the Network Against Racism in Palermo - has made in defending migrants' rights. The leadership taken by the local parish meant that the volunteers did not have to fear any legal reprisals. The involvement of the church also increased the negotiating capacity of the project with authorities. Ventimiglia's experience shows how Catholic organizations can activate citizen responses by appealing to shared cultural conceptions of ethics and fairness, which other organizations are unable to trigger. However, the capacity to generate community engagement and social mobilization through the demand for shared humanitarian values is also one of the limitations of Catholic activism. In Ventimiglia, the Delle Gianchette Church reception project was not based on a political critique of migration governance or of the official migration reception policies, but on the immorality of leaving hundreds of people without shelter. When an alternative was offered by the authorities, the project was not able to overcome this limit because it would have implied a political criticism of the legislation regulating the management of migratory flows. Thus, the legitimacy and social mobilization capacity of Catholic activism in Ventimiglia proved unbeatable when it came to leading a humanitarian project, but was limited with respect to the possibility of defending a political claim. This can be seen even more clearly in the events concerning the issue of the prohibition of food distributions to migrants.

\section{The prohibition of food distribution}

The closing of the official camp at the train station in 2016 was accompanied shortly afterwards by a ban imposed by local authorities on the distribution of food to migrants. In August 2016, this ban became unwavering; Mayor Enrico Ioculano issued Ordinance no. 126/2016 aiming to enforce a 'prohibition of distributing and/or supplying food and beverages in public areas by unauthorized persons.' The ban is not an exceptional practice; it is a widespread strategy developed in different contexts by various local and national governments in the EU during the so-called 'migration crisis' in an effort to create environments hostile to migrants (for a comparative analysis of these practices in Calais and Ventimiglia, see Aris Escarcena \& Da Silva 2018).

This ordinance exempted Catholic activism. Thus, the ordinance collected and legitimized the distributions made in the official reception center and in the headquarters of Catholic activism: the church Delle Gianchette Church and the facilities of Caritas Ventimiglia-San Remo. Indeed, the existence of 
Catholic activism was used by local authorities to justify prohibiting other groups to distribute food.

Nevertheless, the ban affected the volunteers of Catholic solidarity projects: the distribution of food was paradoxically strictly forbidden in the square facing the entrance of the Delle Gianchette Church. This was not a coincidence, but a direct effect of the logic of local politicians, whose aim was twofold: 1) to limit and contain the solidarity movements inside the church; and 2) to oblige the migrants to move to Parco Roya, away from the camping area under the bridge.

The limitations imposed on Catholic volunteers by the food distribution ban significantly advanced these two objectives. According to its own statistics, during 2017 Caritas Ventimiglia-San Remo offered food assistance to an average of more than 2,000 migrants per month, with the peak in August with just over 2,900 people. This assistance mobilized daily more than a dozen volunteers from Monday to Saturday throughout the year. The ban on distributing food was intended to prevent other groups, including those volunteering with Caritas or with the church, from distributing food at night. Thus, besides the breakfast offered by Caritas, many migrants could not receive any food assistance for the rest of the day, which left them with the difficult choice of either going to the official camp or, if they had financial means, look for some place to dine in the city. Both options were inconvenient for those who wanted to continue their journey to France: accessing the camp required inclusion in the Eurodac database; moving towards the city meant leaving the 'tolerance zone' around the church outside which the police forces regularly detained undocumented migrants to deport them to Taranto (in the far South of Italy). The intention was therefore to force migrants who wished to remain in the territory to head for the newly established camp.

\section{The creation of a division within the active civil society in Ventimiglia}

It is important to underscore the social support for local Catholic organizations and the inability of local authorities to prevent their functioning. This social capital is manifested in the fact that local authorities, instead of opposing food assistance by Catholic organizations, tried to restrict volunteer projects that were born alongside them. As pointed out earlier, it is worth analyzing the governmental actions in relation to the interconnection that occurred between volunteers who joined the activities of Catholic organizations first, but whose solidary often exceeded the original projects. The local government, not being able to discredit the Catholic organizations, decided to create a binary opposition between the actions of Catholic activists and the actions carried out by other organizations such as No Borders, Kesha Niya or $20 \mathrm{~K}$. In this way, the local population, which mainly volunteered with Catholic organizations, did not become involved in the actions carried out by other - foreign - organizations. The aim was to prevent 
entities coming from other parts of Italy or from European solidarity movements from putting down roots in local communities through the involvement of local volunteers. This was only partially achieved. While for the majority of the volunteers working in Catholic projects the threat of financial sanctions imposed by the local government for the participation in foreign organization's projects was a deterrent, there was a minority that nevertheless supported other initiatives and allowed these projects to remain in the territory.

On the other hand, Catholic organizations broke the imposed limitations on holidays and days of significant migrant arrivals, as well as on stormy days, when they offered hot drinks and food to migrants at the door of the Delle Gianchette Church or at the train station. During a food distribution on a rainy day one week before Christmas, the volunteers occupied a waiting room of the train station. There, a volunteer told me: 'It is a crime not to give something to eat or a shelter to people who arrive here at night. They arrive completely disoriented, with nothing, sometimes wet and hungry. Per caritá! ["For God's sake!" Literally translated as "for charity's sake"] ... you have to have a little humanity and put yourself in their place' (Volunteer 1, 2017). The local authorities never responded to these activities and the volunteers who carried them out were never compelled to comply with the food distribution ban.

\section{The paradoxical situation of local authorities with respect to humanitarian values}

The moral legitimacy of humanitarian assistance meant that local authorities had to adapt their arguments about migration control policies. The prohibition of food distributions was presented as a measure for the health of migrants: it was presented as an effort by local authorities to ensure that migrants did not receive spoiled food.

When reflecting on the embodiment of values in the migrant reception processes as well as in migration management policies, the prohibition of food distribution and its argumentation are significant. The claim of the local authority for the defense of the welfare of migrants implies falsifying of the fundamental cultural values of the local society, which Catholic organizations actively defended with their assistance. Catholic activism is based on selfless assistance to those in an emergency situation and is represented by the figure of the Good Samaritan. This value is strongly rooted in the culture of European societies and is the basis of legal constructions that have gone beyond their own national legal systems (Pardun 1997) and has established itself as a fundamental principle in international law (an example is the law of the sea, UNCLOS). Charity, as a foundational value of public law, is undermined by such interpretations from the authorities (local in this specific case). The action of Catholic organizations in these contexts becomes thus the last line of defense of both migrants and of a fundamental ethical 
principle, deeply rooted in European societies, as demonstrated by the great response of European citizens to the situation of helplessness and indigence suffered by migrants arrived during the historical phase of the so-called 'refugee crisis.'

\section{The instrumentalization of humanitarian assistance by the authorities}

In the construction of migration management policies, the authorities have used the fundamental values of charity and solidarity in a sense that betrays ethical foundations. The concern for the well-being of migrants expressed in Catholic activism is used to legitimize political projects that directly attack the basic interests of migrants. Thus, instead of showing the contradiction between certain political ends and fundamental humanitarian values, an attempt is made to present these as the basis for political measures such as the prohibition of food distribution. On the other hand, the authorities use the existence of projects led by Catholic activism to reject the need for other forms of volunteerism. The Catholic organizations in Ventimiglia did not formally oppose the ban as long as they were tolerated by the authorities. Unlike the demands made by Catholic organizations regarding the need for public housing structures for migrants in Ventimiglia, there was no claim regarding the need for a public service for food distribution. These inconsistencies lead to a reflection on the limits of Catholic activism and the transformations in the values and conceptions of social solidarity within the institutions linked to the Catholic Church in a political context marked by the opening of all areas of the welfare state to commercialization, as Gray (2016) points out in his analysis of the pro-migrant policies of the Irish Catholic Church.

Volunteering in Catholic organizations was the main way, in which local citizens put into action their moral convictions about the need to assist and to 'do good.' However, the mobilization of social values profoundly linked to the Christian ethic of charity must be analyzed in relation to the transformations of the Church's conceptions on how to organize the moral responsibilities in the current historical context.

\section{Expulsion from the territory}

The limits of the Catholic organizations' actions can be seen in their lack of response to the deportations that took place in Ventimiglia (and that continued to take place at the end of 2018). There were two types of deportation: 1) 'returns' from France to Italy, and 2) deportations (internal deportations) within the Italian territory from North to South.

Returns followed two schemes: deportation of asylum seekers under the Dublin System, and - more relevant for the present analysis - the direct returns under the bilateral Chambery Agreement (République Française \& Repubblica Italiana 2000), an agreement signed by Italy and France to 
manage migration and shared border areas. The Chambery Agreement created an 'express' procedure whereby migrants who were intercepted travelling from Italy to France without permits were immediately deported back to Italy. Different groups of activists, such as Roya Citoyenne or No Borders, opposed this type of semi-legal procedure, which in many cases oversteps legal boundaries as is the case of deportations of unaccompanied minors who should have been placed in the custody of the State (ASGI 2018).

Internal deportations are based on the need for the correct identification of migrants in the Eurodac database and on the 'decompression' of reception structures in Northern Italy. In practice, this meant that those who were apprehended when traveling to France without permits were detained, and subjected to a control to verify whether any documentation on their identity existed and whether their fingerprints had been correctly entered into the Eurodac database; if this was not the case, they were taken into police custody and sent to the hotspot of Taranto. This served as a deterrent and forced migrants to make long journeys or spend their money to return to Ventimiglia. This practice has been strongly denounced by various organizations in Italy (Quadroni \& Luppi 2016).

The situation described above was the third problem encountered by migrants during their presence in Ventimiglia. Beyond the pertinence and il/ legality of this type of dynamic in the management of migrations and borders, if the issue is approached from the point of view of migrants, these practices constitute a source of uncertainty and suffering. Apprehensions and deportations were carried out all over Ventimiglia: all migrants who approached the train station, the market, the health institutions, could be stopped by the police and sent to the hotspot in Taranto if they did not present the appropriate documentation. In France, the situation was not very different. In cities as distant from the border as Nice, or even in Marseille, the police could require documentation at train and bus stations from persons considered to be in transit from Italy, and deport them back if they did not meet the administrative requirements (on the process of determining the 'suspects' of being in an irregular situation see Aris Escarcena 2018). Deportation became thus a 'sword of Damocles' for migrants in transit between Italy and France.

\section{The (lack of) response from Catholic organizations}

The Catholic organizations providing shelter and food assistance in Ventimiglia did not actively oppose deportation policies. Their limited engagement with these issues concerned mainly deportations of unaccompanied minors; actions that depended on professionalized sectors, completely detached from the local voluntary sphere of these organizations. The absence of direct intervention on the part of the Catholic organizations requires a reflection on the limitations of Catholic activism. 
However, it is important to point out that apprehensions enforced for the purposes of deportation within the Italian territory did not occur in the places where Catholic organizations operated, thus, leaving some 'safe' places for migrants in Ventimiglia. The 'protected areas' were in evidence near the Delle Gianchette Church. Except for the informal camps located under the bridge and on the banks of the river, the street leading to the church saw many apprehensions, but the police never stopped the young migrants who occupied the public benches located in the square at the entrance of the church. In the same street, there was a center set up by the 'Eufemia' organization. It became known as the 'Infopoint,' where multiple services were offered to migrants, including an ability to charge telephones, gain access to the Internet or receive legal aid. Numerous migrants came to the 'Infopoint.' However, unlike in the previous scenario, they were frequently detained.

The relationship between the humanitarian structures of the Catholic Church and the social policies of the State is one of the major obstacles to the political positioning of local Catholic activism. At the local level, this is expressed, on one hand, in the immunity of Catholic organizations and their volunteers from policies of repression that affected other organizations, and on the other hand, in the acceptance of migration management decisions and policies that went beyond the humanitarian threshold. This limitation of Catholic organizations to the exclusive implementation of humanitarian/caritative projects is the main drawback of the leadership of Catholic organizations. There are two explanatory dimensions to this issue: 1) Catholic social and humanitarian assistance organizations have become bureaucratized. As T. Waters (2018) explains, this bureaucratization entails serious limitations and results in professionalization, technification, and depoliticization of humanitarian assistance; 2) charity, as a cultural value, has a limitation since it presents assistance as a disinterested concession and does not question the origins of the need for assistance. If humanitarian assistance is exercised as a depoliticized action, charity acquires a paternalistic connotation.

\section{Catholic leadership, between 'euergesia' and social justice}

The leadership of Catholic charity organizations established a final line of defense in situations of complete vulnerability of migrants. The ability to respond to the distress of migrants is a final safeguard when the policies of authorities (local or national) challenge deeply rooted social values. Its potential has been demonstrated by mobilizing social sectors that would otherwise hardly have been involved in activities in support of migrants. This cultural and social capital has been based on the need to defend the social values that are being put at risk. The erosion of rights and the loss of the capacity to exercise basic rights must be considered in relation to the erosion and impoverishment of the cultural systems, in which they are sustained. Resistance to this situation of violation is based on the defense of shared values, which is one of the most basic forms of identification and social belonging. 
However, the issue remains the same as formulated by Muehlebach (2013: 462): 'how we differentiate between paternalistic charity and justice, and how we make charity morph into radical solidarity.' While the leadership of Catholic organizations is an enormous boost in the creation of a last line of defense for migrants, the dynamics of their activism strengthen a limited interpretation of social values, an interpretation that has not allowed us to imagine new forms of social articulation around them. In the analysis of the reconfiguration of values today, it seems useful to reintroduce the concept of 'euergetism' in the sense used by A. Boulanger and his followers, especially B. Dumézil (2005). Here the value of charity is understood as a paternalistic activity exercised as a moral gesture offered from a position of superiority. In this sense, it is opposed to charity understood as a basis for justice. 'Euergesia' would be a social behavior motivated by the same moral principle but opposed in its development into (social) justice. From this point of view, there are two fundamental factors that determine the preponderance of the euergetic sense in the development of humanitarian assistance: 1) the victimization and inferiorization of the subject of assistance, 2) the dislocation between the benefactor and the assisted, and the potential inversion of the sense of the distributive relationship. The depoliticization of projects to assist migrants can lead to the emergence of both factors and, therefore, condition the way in which the assistance action is understood.

Marcel Mauss points out in the 'Moral Conclusions' of 'The Gift' (1966: 63) the need to think of social assistance not as charity but as a social debt contracted as a group with the people who are part of it; and in another fragment (pp. 15-16) he shows the original semantic union of the word charity with justice. There exists today the political need to imagine how to connect the great social agreement existing around the principle of humanity that upholds values such as charity (understood as justice and not as paternalism) with political inclusion projects in the sense presented almost a century ago by Mauss.

\section{Conclusions}

The mobilization of civil society by Catholic organizations has been a positive experience in Ventimiglia. The activities of the Catholic organizations defended migrants' rights from the most aggressive policies that left them destitute. This ability to generate a final line of defense for migrants in the face of the violations of their most basic rights has been based on a call for mobilization around socially rooted values such as charity.

The experience of the Delle Gianchette Church in welcoming migrants and defending their dignity is a seminal example of how Catholic organizations can mobilize great cultural and social capital among local populations. The projects of the Delle Gianchette Church and Caritas Ventimiglia-San Remo can be seen as expressions of local societies' commitment to defend migrants' basic rights (to housing, to not fear persecution or violence, to 
dignity). The ability to appeal to the fundamental values of civil society (values with which the society identifies culturally) has served to oppose the more violent effects of policies that sought to create an unsustainable situation for migrants in Ventimiglia.

The 'immunity' to prosecution and police control (as well as police harassment) granted to volunteers by the leadership of Catholic organizations is an important element in understanding the legitimacy of volunteers as agents who channel and express the convictions of the population before the authorities. In a context marked by the repression of volunteerism, no Caritas volunteer or participant in the Delle Gianchette Church reception project has been prosecuted, arrested, expelled, or removed from the territory of Ventimiglia, as was the case of volunteers who carried out the same type of activities under the coordination of other types of organizations such as No Borders (e.g. expelled under the foglio di via).

In addition to the potentialities of the Catholic organizations' leadership in the social mobilization for the defense of migrants, its limitations and risks have been analyzed. The main limit of this leadership is the inability or lack of will to include a critical positioning in the political sense. The defense of migrants' rights has been led only in areas where it could be exercised with direct assistance to immediate needs and without confronting government authorities. These organizations did not question the policies that kept migrants in a situation of vulnerability, but rather faced their effects. In the case of Ventimiglia as a border area, this has materialized in the fact that Catholic organizations have not participated in defending migrants' right to free movement, remaining on the sidelines of criticism of deportation programs both between the States of France and Italy and within Italian territory.

This limitation questions the interpretation of the value of charity from the perspective of Catholic organizations' activism. If its main potential is the capacity to generate broad-based social support for the defense of the basic rights of migrants, its depoliticization of such defense may imply paternalistic bias in the understanding of these values and the loss of the possibility of a deeper demand for social justice as an inclusive project.

\section{Notes}

1 Since the French and Italian governments exert (physical and symbolic) violence on migrants in the border area, the presence and activity of these organizations serves not only as support, but also as a real defense for migrants.

2 Theoretically, charity has been defined in different ways by the Catholic Church. Fundamental to Christian doctrine are the encyclical letters 1) 'Rerum Novarum' by Leo XIII (1891) and 2) the 'Sollicitudo Rei Socialis' by John Paul II (1987), where the relationship between solidarity and charity - an important issue for this analysis - is established (para. 40).

3 This research is the basis of the documentary project 'Solidarity Crime. The borders of democracy' www.solidaritycrimemovie.com. 


\section{References}

Alldred, P. (2003). 'No borders, no nations, no deportations,' Feminist Review 73(1), pp. $152-157$.

Aris Escarcena, J. P. (2018). 'La paradoja del taxista: Ventimiglia como frontera selectiva,' Mondi Migranti (2), pp. 99-114.

Aris Escarcena, J. P. \& Da Silva, A. C. (2018). 'Deterring solidarity on border spaces: A comparative analysis of food distribution bans in Ventimiglia and Calais,' in Altamirano, D. R., Totah, F. M., \& Keles, F. (eds) Porous Borders, Invisible Boundaries? Ethnographic Perspectives on the Vicissitudes of Contemporary Migration. Washington DC: CORI/SUNTA/AAA.

ASGI (2018). Se questa è Europa - Minori stranieri respinti dalla Francia all'Italia. Asgi.

ASAFFRON Association (2017). 'Grounded theory and ethnography in the study of transit-mobilities of refugees in border zones. Challenges from fieldworks (Italy/ Greece) with people fleeing Syria,' Revista Internacional de Estudios Migratorios 7(3), pp. 131-152.

Burridge, A. (2010). 'Youth on the line and the No Borders movement,' Children's Geographies 8(4), pp. 401-411.

Dumézil, B. (2005). Les Racines Chrétiennes de l'Europe: Conversion et Liberté dans les Royaumes Barbares, Ve-VIIle siècle. Paris: Fayard.

European Union (2000). Council Regulation (EC) No 2725/2000 of 11 December 2000 concerning the establishment of 'Eurodac' for the comparison of fingerprints for the effective application of the Dublin Convention.

European Union (2013). Regulation (EU) No 603/2013 of the European Parliament and of the Council of 26 June 2013 on the establishment of 'Eurodac' for the comparison of fingerprints for the effective application of Regulation (EU) No 604/2013.

European Union (2016). Regulation (EU) 2016/399 of the European Parliament and of the Council of 9 March 2016 on a Union Code on the rules governing the movement of persons across borders (Schengen Borders Code).

Faiola, A. \& Birnbaum, M. (2015). 'Pope calls on Europe's Catholics to take in refugees,' The Washington Post, 6 September. Available at: www.washingtonpost. $\mathrm{com} /$ world/refugees-keep-streaming-into-europe-as-crisis-continues-unabated/2015/ 09/06/8a330572-5345-11e5-b225-90edbd49f362_story.html?noredirect=on\&utm_ term $=.2 \mathrm{ff5} 5 \mathrm{~b} 7665 \mathrm{~d} 86$

Giliberti, L. (2018). 'La criminalizzazione della solidarietà ai migranti in Val Roja: Note dal campo,' Mondi Migranti (3), pp. 161-181.

Gray, B. (2016). 'The politics of migration, church, and state: A case study of the Catholic Church in Ireland,' International Migration Review 50(2), pp. 315-351.

Hess, S. \& Kasparek, B. (2017). 'De- and re-stabilising Schengen. The European border regime after the summer of migration,' Cuadernos Europeos de Deusto 56, pp. 47-78.

Mauss, M. (1966). The Gift. Forms and Functions of Exchange in Archaic Societies. London: Cohen \& West.

Muehlebach, A. (2013). 'The catholicization of neoliberalism: On love and welfare in Lombardy, Italy,' American Anthropologist 115(3), pp. 452-465.

Noborder Network (2004). About noborder.org. Available at: www.noborder.org/about. php.html

Pardun, J. T. (1997). 'Good Samaritan laws: A global perspective,' Loyola of Los Angeles International and Comparative Law Journal 20. 
268 J. P. Aris Escarcena

Quadroni, A. \& Luppi, M. (2016). 'Il “giro dell'oca” dei trasferimenti coatti,' Open Migration.

République Française, \& Repubblica Italiana (2000). Décret $n^{\circ} 2000-652$ du 4 juillet 2000 portant publication de l'accord entre le Gouvernement de la République française et le Gouvernement de la République italienne relatif à la réadmission des personnes en situation (ensemble une annexe), signé à Chambéry.

Tazzioli, M. \& Walters, W. (2019). 'Migration, solidarity and the limits of Europe,' Global Discourses 9(1), pp. 175-190.

Volunteer 1 (2017). Interviewed by J. P. Aris Escarcena at Ventimiglia, December 16.

Waters, T. (2018). Bureaucratizing the Good Samaritan. New York: Routledge. 


\title{
17 Proclaiming and practicing pro-immigration values in Poland
}

\author{
A case study of Poznań
}

Izabella Main

\section{Introduction}

On June 20, 2018 when World Refugee Day was observed, the Polish Prime Minister Mateusz Morawiecki, representing the Law and Justice Party (PiS) announced that he would not take part - as agreed with representatives of other Visegrad countries - in a special working meeting of the European Commission devoted to refugee relocation in Europe. A week later the Prime Minister participated in a meeting of the European Council in Brussels. The meeting was focused on migration and prevention measures to reduce illegal migration (European Council, 2018). After debates on June 28 and 29, 2018, the Council accepted only voluntary participation of EU countries in refugee relocation programs.

EU heads of state or government agreed that on EU territory, those who are saved, should be taken charge of, on the basis of a shared effort, through a transfer in controlled centers. These centers are to be set up in member states, only on a voluntary basis, and should provide rapid and secure processing allowing to distinguish between irregular migrants, who will be returned, and those in need of international protection, for whom the principle of solidarity would apply.

(European Council 2018)

Prime Minister Morawiecki presented this decision as a 'big success of Poland,' concluding two years of negotiations in which Polish politicians representing government objected to any quotas on relocated refugees. The Polish media that supported the present government reported it as a 'huge, gigantic success of Poland', stressing the need to protect EU borders (Do Rzeczy June 29, 2018).

Such a political stance on support for refugees has been represented by the Law and Justice government in Poland, yet, I argue that the situation is far more nuanced when other social actors are considered. The anti-refugee and Islamophobic statements of politicians and the media in the period from 2015 to 2017 were studied in a number of articles and reports (Wrzosek 
2016; Adamczyk 2017; Pędziwiatr 2017; Goździak \& Márton 2018; Klaus et al. 2018). Western media also reported these incidents to a significant extent (Wigura 2016). However, the anti-refugee narrative was and is not the only narrative in Poland as I argue below.

In this chapter, I will address such questions as: what is the rationale of the current government's position on refugees? How it is transmitted to larger public? What are the consequences of the governmental position? What are the alternative responses (practices) of various groups to the 'refugee and migration crisis'? And what kind of pro-immigration values are referred to by groups and individuals advocating openness to migrants and refugees?

This chapter is based on an analysis of media coverage, public opinion polls, and fieldwork conducted in Poznań, a city in Western Poland. I decided to focus on Poznan for a variety of reasons. The migrant population of the city is growing, especially in recent years. The current Mayor of Poznań, Jacek Jaśkowiak, proclaimed support for migrants on a number of occasions. Additionally, I was able to observe first-hand several campaigns and actions in support of refugees and migrants that took place since 2015.

Despite the increase of the foreign-born population in Poznań, the number of migrants remained small until recently. In 2014, Poznan - with a population of 550,000 - had only around 2,600 foreign-born individuals registered as city residents and an additional 2,300 foreign-born students (Czerniejewska \& Main 2015). In 2017, the number of registered migrants reached 7,000, although some estimates doubled the number, indicating that as many as 15,000 foreign-born lived in Poznań (Urzad Miasta Poznania 2017). The majority came from the Ukraine, mainly to work and/or study. There are also small groups both from European Union countries and from Algeria, China, India, Korea, Saudi Arabia, and the United States. These groups have slightly increased the religious diversity ${ }^{1}$ of the city, although the newcomers are, like the rest of Poland, predominantly Catholic or Christian.

In this chapter, I will first discuss the attitude of the Polish government towards admitting refugees and the values they referred to in order to justify their positions. Second, I will outline the consequences of anti-refugee and anti-Muslim positions, visible in the results of public opinion polls and attacks against migrants. The next two parts are devoted to the Poznań city authorities' positions and local initiatives advocating openness and support to migrants and refugees. The chapter includes the discussion of values referred to by different social actors to justify views and actions in relation to refugees and migrants.

\section{The evolution of the Polish government's attitudes towards refugees}

In mid-2015, the coalition government of two parties - the Civic Platform (Platforma Obywatelska) and the People's Party (Stronnictwo Ludowe) committed to accepting some 7,000 refugees from Syria, Iraq, and Eritrea for 
settlement in Poland through the relocation program. During a televised speech, the then Prime Minister, Ewa Kopacz, declared:

Poland will accept only refugees, not economic migrants... we assure you that in the on-going negotiations, we set such conditions as separating refugees from economic migrants, sealing EU exterior borders, and controlling of accepted persons by our security services. Poland is and will be secure, Poland is and will be pro-European, Poland is and will be tolerant.

(Kopacz 2015)

Ewa Kopacz was referring to values such as security, pro-Europeanness, and tolerance. She stressed that in recent years Poland gained a lot as a result of European solidarity and that Europe expects solidarity from Poland. At that time, the Civic Platform was trying to both compromise with EU expectations and satisfy the Polish electorate. The government was therefore referring to solidarity and tolerance, yet also to securitization (Pedziwiatr $\&$ Legut 2017; Bałamut 2018). It was also emphasizing its pro-European position.

After the general election on October 25, 2015, the new government, controlled by the conservative Law and Justice Party (PiS), rejected previous commitments and openly confronted the EU on refugee relocation. It also promoted negative media coverage of the 'refugee and migration crisis' and fueled nationalist anti-refugee sentiments. This process started during the electoral campaign in 2015, when politicians of the PiS and KORWiN ${ }^{2}$ parties, as well as part of Kukiz' $15^{3}$ parties, addressed the issue of refugees using negative ideas and images. In October 2015, Jarosław Kaczyński - the leader of the Law and Justice Party - spoke of 'Different types of parasites, protozoa that are not dangerous in the bodies of these people [refugees], [but] could be dangerous here' (Kaczyński 2015). The fear of infectious diseases was combined with the issue of security. The discourse of contamination was reproduced at different sites and in different historical moments in the name of national security. Using the case of the Ebola virus, Carmela Murdocca (2003) has shown how the diseased and degenerate body has been produced in media to ensure the exclusion of racialized bodies, to control immigration, and to produce a subordinate group. Regardless of the available epidemiological evidence, metaphors of the plague and infection have been used to marginalize and keep out diaspora communities in host countries in an effort to 'exclude filth'. These fears of the immigrant body and its movement have been expressed in relation to infectious diseases: Avian flu, SARS, HIV/ AIDS, cholera, tuberculosis, and the plague (Harper \& Raman 2008).

In Kaczyński's speech, refugees were also portrayed as terrorists, especially in reference to the war in Syria and terrorist attacks in Europe. Kaczyński was by no means the first politician to refer to immigrants as parasites or criminals, such references were present in the United States in the 1990s and later. It has been argued that immigrants have become a new enemy in post- 
cold war period in the framework of Us vs Them. Furthermore, Sang Hea Kil convincingly shows the link between racism and nationalism:

From the physical body that experiences disgust and abjection projected symbolically onto the nation in a sexualize nightmare about crime, to the nation where the militarization of the border protects the imagined line between pure and impure, harmony and hostility, calm weather and cataclysm, nativist discourse maximizes the use of 'racist dirt fixations' and the nested scales in a veiled way to impose whiteness on the nation.

(Kil 2013: 19)

Racialization - along with stereotyping, objectification, and whiteness as a norm - was one of the strategies of othering present in both Polish and British mass media, as well as experienced by the othered individuals (Strani \& Szczepaniak-Kozak 2018).

Beata Szydło - who led the campaign of Andrzej Duda, the presidential nominee of PiS - mentioned security as a key concern of the government during a convention in September 2015. The issue of accepting and relocating refugees was mostly addressed in public speeches and media interviews, but hardly ever in official documents or electoral programs (Lason 2018). Szydło, the Prime Minister since November 16, 2015, not only questioned the numbers declared by the previous government $(7,000)$, but in January 2016 she stated that 'Christians should be given preference' (Pędziwiatr \& Legut 2017: 624). This statement corresponds with another theme in the government's stance on refugees, namely the assertion that refugees pose a threat to the Christian identity of Europe, and that the arrival of predominantly Muslim refugees would lead to the 'Islamization' of Europe and demographic changes in favor of Islam. The title of one of the articles published in a popular periodical - 'Islamic rape of Europe' (wSieci $\left.{ }^{4}\right)$ - exemplifies such attitudes. This caption attracted a lot of attention around the world. International newspapers, such as The Washington Post and The Independent, called the cover 'shocking, highlighting stereotypes used by the graphic designer and relating them to racist images of Jews and Blacks from the first half of the twentieth century' (Wigura 2016).

Polish politicians' Islamophobia was revived on many occasions. As pointed in the European Islamophobia report, in 2016, 'Islamophobic views become even more mainstream not only in politics, but also in the media, education, and other spheres of life' (Pędziwiatr 2017: 414). Poles have limited contact with the tiny Muslim population in Poland, yet they have started to imagine that there are many more Muslims than the actual numbers would suggest (Bobako 2017; Buchowski 2016). The state-owned media, transformed after the elections to promote the government's positions on migration, reinforced Islamophobic views by inviting critics of Islam to present Muslims as terrorists and manipulating media coverage of various events. 
These anti-refugee attitudes continued in subsequent years. Just before the regional elections on October 21, 2018, the Law and Justice Party aired an anti-refugee spot, which used very strong nationalistic rhetoric, on public television. The one-minute spot portrayed Poland of 2020 as a country ridden with Muslim refugee enclaves and citizens afraid to leave their houses after sunset due to prevalence of sexual attacks, aggression, and violence. Poland's Ombudsman and some other politicians objected to airing the spot, but to no avail. The media continued to broadcast nationalist and anti-refugee programing presenting refugees as a threat, emphasizing their supposed aggressiveness and criminality, or claiming their readiness to destroy the Christian civilization (see Goździak \& Márton 2018; Krzyżanowska \& Krzyżanowski 2018; Pędziwiatr 2018).

\section{'Refugees are coming' - moral panic in the making}

There were several consequences of such mis/mal-representation of refugees in Poland. First, there was a gradual change of the society's attitudes towards refugees and Muslims. Numerous public opinion polls about attitudes towards refugees in Poland were conducted in recent years. The analysis of the polls shows that very few people have no opinion about refugees, a mere four percent. This stands in sharp contrast with the standard 30 percent indicating indifference to political and social issues. This demonstrates that the topic of refugees has become very important to Poles. This topic resulted in increased interest in the social phenomenon of migration and heightened emotions. The situation of refugees was addressed on many occasions and used for many political ends. Furthermore, negative attitudes towards accepting refugees rapidly increased between May 2015 and December 2016. In 2015, only 21 percent of Poles did not want to offer protection to refugees, while in the following year as many as 52 percent of Poles were against offering refuge to asylum seekers. There has been a clear correlation between negative views of migrants or refugees and support for right-wing political parties (Adamczyk 2017: 331; CBOS 2017a; CBOS 2018). The only group of migrants welcomed by Poles would be those coming from the Ukraine. Fifty-five percent of Poles supported the admission of Ukrainians, according to public opinion pool from second half of 2016 (CBOS 2017b).

The second consequence of the anti-refugee discourse was an increase in anti-migrant sentiments and actions. This tendency is visible in the results of public opinion polls showing escalation of negative attitudes towards other nationalities, including migrants living in Poland (Cekiera 2017). For many Poles, there is no positive aspect of contact with migrants or refugees as a way to enrich the local culture (Łaciak \& Segeš Frelak 2018). This is not entirely surprising given the ethnic and religious homogeneity of the current Polish society (Buchowski 2016). The third consequence was an increase in racist and anti-immigrant attacks in recent years in Poland. The Never Again Association, monitoring such violence in its magazine, points out a 
continuously growing number of assaults on foreigners, taking place both in larger cities and smaller towns in Poland. Verbal abuses and physical attacks were directed against people who looked or behaved differently: individuals with darker complexion, speaking foreign languages, wearing different clothes, and/or perceived to be Muslim (Never Again Association 2019).

The previously described process of spreading and reinforcing anti-refugee, anti-migrant, and Islamophobic views and attitudes, and the resulting actions, can be explained using the concept of moral panic (Cohen 2017). Moral panic is characterized by disproportionate and inaccurate societal reactions to a serious situation or a threat. Barbara Pasamonik (2017) argues that 'Polish transformational panic about refugees is part of a broader culture war within the West - a clash of traditionalism and modernism, conservatism and liberalism of lifestyle, moral fundamentalism and relativism.' She stresses the conflict between pro-refugee narration, labelled as humanitarian, and anti-refugee one, labelled as nationalist. Both refer to moral values. As indicated above, politicians and groups promoting anti-refugee discourse referred to nationalist and/or Catholic values, emphasizing the value of ethnic and religious homogeneity and security. In the next part, I will look at actions and related values at the local level in Poznań.

\section{Responses to the 'refugee crisis' and values in the city of Poznań}

Research and writing about Polish responses to refugees seeking safe haven in Europe have focused mainly on the anti-refugee discourses and actions. However, some media outlets, reports, and empirical studies emphasized that there is a part of the Polish society that expresses solidarity and the basic humanitarian desire to help, but these efforts are often overshadowed by the anti-immigration discourse (see Tracz 2018). Some activists, members of the civil society and academia, have attempted to influence the debate through positive messages. It is worth mentioning the example of the Polish Day of Solidarity with Refugees, which took place on October 15, 2015, and involved 130 institutions (NGOs, theatres, museums, etc.) or grass root initiatives such as 'Chlebem i sola [With bread and salt]' aimed at improving the refugee situation in Poland and Europe (Eaciak \& Segeš Frelak 2018).

NGOs and informal groups have been the main social actors involved in supporting refugees and migrants in Poland since 1989. Their activities are often sponsored by international organizations and EU funds. Gradually some city mayors and councils have gotten more involved as a result of the recognition of the necessity to attract economic migrants to Poland and to better integrate newcomers already living in Poland. Several cities started to provide financial support to programs offering education, legal support, and integration activities for migrants. This support was needed especially after the current government limited the possibilities of receiving EU funds by NGOs supporting migrants and refugees (Prończuk 2017; Wyrwał 2017). 
One of the important recent initiatives was prepared by twelve city mayors representing the Civic Platform Party in Poland. On June 30, 2017, the cities of Białygostok, Bydgoszcz, Gdańsk, Kraków, Lublin, Łódź, Poznań, Rzeszów, Szczecin, Warszawa, and Wrocław signed a declaration promising to cooperate in supporting migration and migrants. Its fragments referring to values are particularly interesting:

Migrations are dynamic processes, common and - as the history of the world shows - inevitable, and in the context of the socio-demographic situation of our country - even beneficial. Polish cities have been open to migration processes and the diversity of residents for many years. ... We declare cooperation of cities through the exchange of experience and good practices, in order to ensure a high quality of life for all residents, in a spirit of solidarity and responsibility for the community that we create together with migrants. We declare openness and the will to partner in partnership with government administration, non-governmental organizations, and religious associations in the field of creating and implementing Polish migration policy, based on managing safe migration [bezpieczne migracje]. Together, we are able to develop an appropriate culture of accepting migrants, which will help develop our cities, make them more innovative and competitive.

(Deklaracja 2017)

The authors of this declaration - among them the Mayor of Poznan - stressed several values such as openness, diversity, solidarity, responsibility, acceptance, economic advantage (beneficial), and safety. The emphasis of these values can be seen as an expression of an on-going process of acceptance towards migrants and refugees but also as resistance to the conservative policies of the PiS government.

The city of Poznań established its first initiatives targeting migrants as early as 2009, when Poznan got involved in the 'Open Cities' project, organized by a consortium of several European cities and the British Council. The idea of an 'open city' was created by an international team within the EU program for the Urban Development Network. Wojciech Bauer, who coordinated this project in Poznan, stated that the goal of the project was 'to increase the level of openness of Poznan and its inhabitants, increase the attractiveness of the city and its labor market, attract foreign human capital, and better integrate immigrants' (Kościesza 2014). As result, the 2011 document 'Local plan of action' recommended that Poznań become an 'open city' (Sydow 2017). Subsequently, the city was a partner of an EU founded project 'AMIGA. An active approach to the labor market' (2013-2015), though the project was the result of an initiative of several researchers at Adam Mickiewicz University in Poznań. Migrant Info Point (MIP), a program offering information and support for migrants, ${ }^{5}$ was a direct outcome of the AMIGA project. In subsequent years, the city was a partner in several 
initiatives supporting migrants and refugees, such as Adopt a life vest, ${ }^{6}$ the Gallery without a home, ${ }^{7}$ and Airbag Poznan. ${ }^{8}$

On Saturday, July 18, 2015, a group of Poznań activists, including artists, academics, and anarchists, organized a pro-refugee demonstration 'In Solidarity with migrants [Solidarni z migrantami].' The Mayor, Jacek Jaśkowiak, joined the demonstration. This gesture of support from the city mayor showed his understanding of what it means to be an open city. Some of the statements during the demonstration directly referred to values, such as: 'We need to offer solidarity to people in need,' 'Poznań should be for all, Poland should be for all.' The last slogan actually undermined a popular statement of the right-wing radical movements: 'Poland for Poles.' During this demonstration, a counter-demonstration was organized by anti-Muslim organizations (Nyczka \& Żytnicki 2015). The day of October 15 was proclaimed as the Day of Solidarity with Refugees with events organized in many Polish cities in 2015 and 2016, including in Poznań (Dzień Solidarności 2016). In the name of international cooperation and human solidarity, meetings, social actions, artistic activities, workshops, discussions, lectures, exhibitions, happenings, film screenings and concerts were organized across Poland. The actions were very diverse, informing about the situation of refugees in various contexts, fundraising for refugees and solidarizing during demonstrations.

The government of Poznań was searching for new ways to present itself. After its self-presentation as open city and as city offering solidarity with migrants and refugees, in summer 2017 it started a campaign called 'Free City Poznań [Wolne Miasto Poznań]'. It consisted of t-shirts and promotional materials with the iconic inscription 'Free City Poznań' using symbols of religions and movements, such as the Christian cross, the Star of David, the Muslim crescent, a rainbow, a bike, a green leaf, a wheelchair, and a family, incorporated as part of the letters. The motto 'Free' was used to emphasize independence from the state government.

Another concept - 'respect' - was used during a social campaign named 'We Poznań 36.6 - Tolerance is not enough' in December 2017. Its aim was to oppose existing stereotypes and prejudices against refugees and migrants as well as other discriminated groups. The search for a common denominator to connect people was the starting point of this campaign. It was a body temperature of $36.6 \mathrm{C}$. The description read:

Respect for every human being and fight against discrimination - these are the main goals of the campaign, which has just been launched in Poznań. The action reminds us that it is not worth judging others based on stereotypes and superficial opinions.

The Constitution of the Republic of Poland guarantees every human being the right to respect for personal dignity - said Jacek Jaśkowiak, the city mayor. All discrimination is a violation of this right and leads to passivity and lack of response. It is time to change it. Through the 'We 
Poznań 36.6' campaign, we want to remind everyone that we are all equal, and respect is an inalienable right of every person

(My Poznań 36.6 2017)

The campaign was organized by the City Promotion Office, which worked with a private agency. On December 9, 2017, everyone could attend the event organized in the Old Market Square and accompanying the Ice Sculpture Festival in Poznań. Residents and tourists could see, in real time on a large screen, what they looked like in a thermal imaging camera.

All superficial differences lost their importance: clothing, skin color or sexual orientation disappeared - said the deputy director of the Mayor's Office, Patryk Pawełczak. What was left was the image of people who are the same, who have the same temperature and the same rights. In our campaign, it is all about rights.

(My Poznań 36.6 2017)

A movie promoting the campaign was also filmed during the event and later shown on public transportation and placed on YouTube channel. ${ }^{9}$ The narrator in the two-minute film stated that 'stereotypes disrupt our vision' and that 'the same thing can be called differently.' The words illustrating such cases accompanied the pictures: senior - grandma - katol [Catholic] moher [pejorative for conservative Catholic old women]; actress - girlfriend asfalt [pej. black]; student - hipster - biker - kujon [crammer] - ciapaty [pej. Indian/Bengali/etc.] - brudas [dirty]; boy - student - son - pedat [pej. gay]; family - children - socjat [pej. living on social services]. The final seconds contained the following message: 'In Poznań tolerance is not enough, in Poznań we return to respect.'

The campaign referred to the concepts of respect and dignity as grounded in the rights and laws guaranteed in the Polish Constitution (Chapter II, Article 31 and 32). This campaign can be seen as a move from solidarity with the Others, the needy, the suffering, the victims to a position when we, people, humans, are all the same, have the same body temperature, the same right to respect and dignity. It can be seen as an attempt to humanize all people who are discriminated against. The movie is not directly commenting on refugees yet there are many references to migrants and people who are not white. It ends with a call: 'If you encountered discrimination - react.'

\section{Civil society responses}

Several registered and informal civil society groups in Poznań started grassroot responses to anti-refugee and Islamophobic national government's decisions and statements. These responses were described by some activists as expressions of their individual responsibility for the world (Jarosz 2019). 
There were two types of actions taken in support of refugees. First, public campaigns, demonstrations, meetings, and workshops aimed at changing social attitudes, expressing solidarity, and openly supporting refugees and migrants. Second, there were a number of group and individual activities aimed at collecting financial support and material goods to be transported to refugee camps in Bulgaria, Greece, and Syria. These groups and actions represented humanitarianism abroad, since refugees were not admitted to Poland, yet their scope was limited due to lack of resources. Activists participating in crowdsourcing campaigns and those collecting material goods were often the same people. In this chapter, I focus on the public campaigns, demonstrations, and meetings because they invoked values.

There are no recent public opinion polls on the attitudes to refugees and migrants in Poznań (Mamzer 2011; Goździak \& Nowak 2012). The conclusion of the 2018 report 'Shaping fair cities: Integrating Agenda 2030 within local policies in times of great migration and refugees' flows,' based on 750 questionnaires with Poznań residents, read:

respondents strongly agreed with statements referring (in general terms) to human rights and those related to humanitarian aid - ensuring the possibility of satisfying the basic needs of people in a situation of higher necessity. Poznań residents agree that international action is needed to ensure safe and regulated migration flows, but at the same time they wanted to help foreigners in their place of residence, and grant Polish citizenship only to those who adapt to their way of life.

(Kwiecińska-Zdrenka 2018)

This quote shows that the solutions proposed by the current government regulated migration and support in the countries of conflict - are accepted by the majority of population. The restrictions on granting citizenship are particularly interesting. At present, there are no citizenship tests. Citizenship is granted on the basis of a specified length of registered residence and a certificate of Polish language knowledge.

The actions and campaigns in Poznan that aim at changing attitudes were mostly initiated by local NGOs. One of the campaigns named Adopt a life vest consisted of adoption of life vests, which were brought from the Kios Island to Poznań by Oxfam International for a street happening in the late 2016. In February-March of 2017, the Centre for Migration Studies and the Migrant Info Point decided to utilize the vests previously used by people crossing the Mediterranean Sea in an awareness raising campaign and display them in public spaces throughout the city: in cinema armchairs, at a coffee table in a local cafe, in a lecture hall, in a classroom, in a waiting room, and in an office. The often dirty, partly damaged adult and child size vests symbolized the absence of refugees in Poznań. The goal of the campaign was to encourage institutions and individuals 'to adopt' a vest to display it and organize meetings to talk about refugees. More than 40 institutions joined in 
(Akcja 'Zaadoptuj kamizelkę' 2017). None of the Catholic parishes decided to adopt a vest in spite of the organizers' encouragement ${ }^{10}$.

Labels with information were attached to the vests:

We do not know if those who were wearing them reached the shore safely, we do not know what happened to them. We know that they are not in Poland. But these vests remind us about their absence among us.

The action aimed at drawing attention to individuals who used these vests, to encourage people in Poznań to imagine such travel, and to think what it would take to make a decision to travel on a boat through the sea (Kwiatkowska 2017). The campaign aimed at drawing attention to the results of political decisions not to allow refugees to Poland, to raise awareness, to trigger emotions, to induce discussion, and to make society think about refugees. The organizers realized that anti-refugee discourse was present in the mass-media, which referred to anonymous 'waves,' threats, and problems, while people still crossed the sea risking their lives. The goal of the campaign was to strengthen the language of compassion and to empower people who did not agree with dominant anti-refugee discourse in the public sphere in Poland. The vests in cafes, cinemas, restaurants, schools, and offices represented people who would like to sit in these places and drink coffee, watch a movie, study, and live in a safe place. Absent refugees were represented as people with the same needs as the inhabitants of Poznań.

The message addressed to people in the Adopt a life vest campaign called them to be active:

We have the enormous privilege to live in a safe part of the world. The fact that we were born right here is a coincidence. However, what we do with this privilege is by no means accidental. It's a matter of our decision. Will we enjoy our well-being and hide from those who were by chance deprived of the possibility of a dignified life without fear or will urge solidarity?

(Akcja 'Zaadoptuj kamizelkę' 2017)

Comments were solicited from the people who encountered the life vests. A person sitting next to one of the life vests wrote about her emotions, saying: 'I sat with her at one table! We ate the soup. I wanted to ask her so much. So much to tell her. And this big, growing lump in my throat - a mixture of shame, grief, compassion, and rage.' Many reactions to the vests were very emotional, exactly as intended (I was part of the organizing group). The campaign was accepted with interest and enthusiasm to a greater degree than expected by the organizers, showing that people wanted to take a step and to help refugees.

During the campaign, several references were made to organizations supporting refuges, so that people could join them in their efforts. At that time, 
a number of NGOs and informal groups such as Humans of Aleppo, From Poznan with Love, Garage Sale, and others organized events, protests, happenings, discussions, and displays addressing the situation of migrants and refugees. These groups often mobilized for particular goals, such as collecting resources in Poznan or through crowdfunding portals, using social media, especially Facebook, and communicating and popularizing actions.

For example, From Poznan with Love was an action started by two individuals who were inspired after one of them returned from Nea Kavala camp in Greece where she volunteered and reported the enormous needs there. During a few weeks in December 2016, the action involved not only collecting money, but also the writing of letters to children in the camp by Polish pupils. It was estimated that half of the 800 people in the camp were children. The letters were translated to English and Arabic so that children in the camp could read them (Nyczka 2016). The money was to be used on the spot to provide food so that people in the camp could cook their own meals. The action organizers saw it as a way to bring back dignity, to give refugees a chance to make tea whenever they wanted. Since 2016, six Garage Sales were organized to support refugees and civil society organizations in different camps in Greece and Yemen. Recently, another Garage Sale was organized to collect money for an 'emergency fund' for few refugees living in Poland.$^{11}$ In this way Garage Sales were expression of activities exemplifying humanitarianism abroad and at home. Miriam Ticktin (2006) argued that humanitarianism (and human rights) is complexly constituted transnational institution, practice, and discursive regime, constructed around and about the ethical and moral imperative to bring relief to those suffering and to save lives.

Many activists I have spoken with mentioned the dehumanizing aspects of the government and the right-wing parties' campaigns. This discourse robbed refugees of their humanity. As Malkki (1996) wrote: 'Refugees stop being persons.' Thus, one of the main objectives of the above-mentioned actions was to refer to refugees as individuals with emotions, feelings, and needs. During one of the debates organized in Poznan, an invited speaker, Professor Anna Wolff-Powęska, said

We must ask ourselves questions about our humanity and politics: whose life has value for us? Who do we consider to be our neighbor, a human being? Why do we bend over one suffering person and not over another? We face the test of humanity.

(Salwacka 2017)

Values are an integral and important part of our lives, yet at the same time they are abstract things, which are difficult to talk about with any degree of specificity (Bednarek-Gilland 2017). This opinion is confirmed by my observations in the field - when talking with activists or reading media materials and documents there was hardly ever reference to values. The most commonly mentioned human values and rights included: right to dignity, 
respect, freedom, safe home. The motivations of people involved in these actions are often very general as well: 'so I am not ashamed in the future,' 'to give the next generation a future,' 'because we want to create a common vision of future.'

\section{Conclusions}

The perspectives and attitudes of the state government, the media, city authorities, and grass-roots initiatives towards refugees and migrants in Poland have been very diverse since 2015. The explanations, justifications, and values referred to in anti-refugee and pro-refugee actions and campaigns are in some cases contradictory. Discussions in Polish public sphere represented a case of strong polarization of opinions and attitudes towards refugees (Hall \& Mikulska-Jones 2016), which divided society, and in many cases groups and families.

The European Union has been a strong reference point since the EU-led actions and discussion influenced debates in Poland. At the same time, EUsponsored programs, and initiatives in support of migrants, especially third-country (non-EU) nationals - e.g. on the labor market - have been taking place for many years in Poland. These programs were aimed at the integration of migrants, including not only teaching them to speak the Polish language and how to function in every-day situations, but also addressing Polish society in order to change attitudes and support openness. Besides, many other activities were initiated and have been taking place without EU funding, supported by small grants (e.g. of the city of Poznań) and/or based on the volunteering of local groups and organizations, representing civil society.

Several actions described above were directly referring to diverse values solidarity, respect, openness, dignity. When I asked activists about the values which stimulated them to be involved, they stressed humanitarianism and human values. There were two major goals of the actions: 1) to support refugees and migrants (in Poland and abroad) and 2) to educate and activate Polish society to counterbalance negative discourse supported by the PiS government and state-supporting media. The result of the first was often 'a drop in the bucket,' given that measuring the outcomes of the actions aiming at social change is methodologically and epistemologically difficult, a longterm perspective is needed. Still there was an optimism among activists who started the innovative ways of supporting refugees and pro-refugee attitudes - they were based on a feeling of finding other involved people and groups across Poland, getting the support of some local authorities, and/or establishing international contacts with civil society individuals and groups. There were also, however, many concerns - about future politics, the modest involvement and support of society at large, the small chance of (and interest in) intercultural contacts and especially contacts with refugees which, in the opinion of activists, would decrease fear and de-humanizing practices. 
Finally, the rapidly growing Ukrainian migrant population in Poland has brought about new challenges. ${ }^{12}$

\section{Notes}

1 In 2005, the Muslim community created Muslim Cultural-Educational Centre, offering religious services, language courses, workshops and discussion meetings; new evangelical churches also organize their religious worship in Poznań.

2 KORWiN was a right-libertarian and Eurosceptic party established in 2015 by Janusz Korwin-Mikke.

3 Kukiz'15 - right wing and far-right political movement.

4 'wSieci' is a conservative weekly, established in 2012; in 2016 it had fourth place on the list of best-selling weeklies.

5 After 2015, the city of Poznań substantially contributed financially to its activities, since international programs became less available.

6 This action will be described in detail in next part of the chapter

7 'Gallery without a home' was an initiative of Migrant Info Point and the Centre for Migration Studies, financed by Oxfam International between November 2017 and March 2018. It consisted of workshops entitled 'I hear, feel, and understand. Stories of young refugees' for 8-10-year-old children in Poznań schools - pupils heard the stories and drew postcards for refugee children. These postcards were sent to refugee children in Italy and Greece. Their copies were displayed during the mobile exhibition entitled 'Gallery without a home.'

8 'Airbag Poznan' - a project organized in Poznań since 2018 aiming at increasing the security of foreigners in Poznan. Cafe, restaurant and pub personnel were trained in how to react to violence, report it to police and support victims until the arrival of policemen. The places of support are marked with an airbag symbol.

9 A leaflet was also prepared and distributed. The campaign Poznań 36.6 was later included into 'Cities4Europe - Europe for citizens: involve - inspire - impact' project, which includes 'a series of local events showcasing successful local initiatives that engage citizens, present ideas for new forms of democracy and map out a positive, common future' (Cities4Europe 2017).

10 This was not a surprise given the very ambivalent position of the Catholic clergy. See: Pędziwiatr 2018.

11 On countries of origin and number of refugees in Poland see Klaus, this volume.

12 See Klaus in this volume.

\section{References}

Adamczyk, A. (2017). 'The influx of persons seeking international protection in Poland compared to other EU states during the EU Migration Crisis (2014-2016),' Rocznik integracji europejskiej 11, pp. 329-341.

Akcja 'Zaadoptujkamizelkę' (2017). Centrum Badań Migracyjnych UAM. Available at www.cebam.amu.edu.pl/221-akcja-zaadoptuj-kamizelke.html

Bałamut, A. (2018). 'Polska wobec kryzysu imigracyjnego w Unii Europejskiej,' in Molo, B. (ed.) Migracja i uchodźstwo wyzwaniem dla bezpieczeństwa i wspótpracy międzynarodowej w XXI wieku, Kraków: Krakowska Akademia im. Andrzeja Frycza Modrzewskiego, pp. 103-120.

Bednarek-Gilland, A. (2017). Researching Values with Qualitative Methods. Empathy, Moral Boundaries and the Politics of Research. London and New York: Routledge. 
Bobako, M. (2017). Islamofobia jako technologia władzy. Studium z antropologii politycznej Kraków: Universitas.

Buchowski M. (2016). 'Making anthropology matter in the heyday of Islamophobia and the "Refugee Crisis": The case of Poland,' Ćeský lid (103), pp. 51-67.

CBOS (2017a). 'Stosunek Polaków do przyjmowania uchodźców,' Komunikat z badań nr 1. Warszawa: Centrum Badania Opinii Publicznej.

CBOS (2017b). 'Stosunek Polaków do przyjmowania uchodźców,' Komunikat z badań nr 44. Warszawa: Centrum Badania Opinii Publicznej.

CBOS (2018). 'Stosunek Polaków i Czechów do przyjmowania uchodźców,' Komunikat z badań nr 87. Warszawa: Centrum Badania Opinii Publicznej.

Cekiera, R. (2017). 'Między gościnnością a misoksenią - reperkusje kryzysu migracyjnego w Polsce,' Political Preferences 17, pp. 237-250.

Cities4Europe (2017). 'My Poznań 36.6'. Respect for every human being,' Available at http://cities4europe.eurocities.eu/eu-campaign/index.html\#/activity/700013

Cohen, S. (2017). Folk Devils and Moral Panics. The Creation of the Mods and Rockers. London and New York: Routledge.

Czerniejewska, I. \& Main, I. (2015). 'Statystyczny obraz zjawiska imigracji do Poznania,' in Bloch, N., Main, I., \& Sydow, K. (ed.) Nie dość użyteczni. Zmagania imigrantów na lokalnym rynku pracy. Poznań: Centrum Badań Migracyjnych, pp. 153-173.

Deklaracja (2017). 'Deklaracja 12 prezydentów dużych polskich miast: Migrację trzeba wspierać,' Polityka, 30 June. Available at: www.polityka.pl/tygodnikpolityka/kraj/ 1710710,1,deklaracja-12-prezydentow-duzych-polskich-miast-migracje-trzeba-wsp ierac.read

DzieńSolidarności (2016). Dzień Solidarności z Uchodźcami. Polska przeciw rasizmowi $i$ przemocy. Available at http://solidarnizuchodzcami.pl/apel/

European Council (2018). Meeting 28-29/06/2018. Main results. Available at www. consilium.europa.eu/en/meetings/european-council/2018/06/28-29/

Goździak, E. M. \& Márton, P. (2018). 'Where the wild things are: Fear of Islam and the anti-refugee rhetoric in Hungary and in Poland,' Central and Eastern European Migration Review 7, pp. 125-151.

Goździak, E. M. \& Nowak, L. (2012). 'Ten Obcy. Stosunek Wielkopolan do Cudzoziemców,' Przeglad Wielkopolski 1(95), pp. 17-28.

Hall, D. \& Mikulska-Jones, A. (2016). 'Uprzedzenia, strach czy niewiedza? Młodzi Polacy o powodach niechęci do przyjmowania uchodźców,' Analizy, Raporty, Ekspertyzy. Stowarzyszenie Interwencji Prawnej 1.

Harper, I. \& Raman, P. (2008). 'Less than human? Diaspora, disease and the question of citizenship,' International Migration 46(5), pp. 3-26.

Kil, S. H. (2013). 'A diseased body politic,' Cultural Studies 28(2), pp. 1-22.

Jarosz, E. (2019). 'Świat stał się za mały, żeby żyć wyłącznie dla siebie,' Rozmowa z Paulina Kuntze magazynrtv.com. Available at http://magazynrtv.com/wydanie-1/ wywiady/swiat-stal-sie-za-maly-zeby-zyc-wylacznie-dla-siebie-rozmowa-z/

Kaczyński, L. (2015). 'Kaczyński: Pasożyty i pierwotniaki w organizmach uchodźców groźne dla Polaków,' Newsweek. Available at: www.newsweek.p1/polska/jaroslaw-ka czynski-o-uchodzcach/89mwbx3

Klaus, W., Lévay, M., Rzeplińska, I., \& Scheinost, M. (2018). 'Refugees and asylum seekers in Central European Countries: Reality, politics and the creation of fear in societies,' in Kury, H. \& Redo, S. (eds) Refugees and Migrants in Law and Policy. Cham: Springer, pp. 1-34. 


\section{4}

Kopacz, E. (2015). 'Polska przyjmie tylko uchodźców, nie emigrantów ekonomicznych,' Polska Times. Available at: https://polskatimes.pl/ewa-kopacz-polska -przyjmie-uchodzcow-ale-nie-imigrantow-ekonomicznych/ar/8168870

Kościesza, K. (2014). Wywiad z Wojciechem Bauerem koordynatorem projektu Open Cities - Urzad Miasta Poznania. Available at: http://cw.org.pl/aktualnosci/ 97-wywiad-z-wojciechem-bauerem-koordynatorem-projektu-open-cities-urzad-mia sta-poznania

Krzyżanowska, N. \& Krzyżanowski, M. (2018). "Crisis” and migration in Poland: Discursive shifts, anti-pluralism and the politicisation of exclusion,' Sociology 52(3), pp. 612-618.

Kwiatkowska, A. (2017). 'Akcja "Zaadoptuj kamizelkę” przypomni o uchodźcach', Gazeta Wyborcza, 3 February. Available at: http://poznan.wyborcza.pl/poznan/ 7,36001,21331753,akcja-zaadoptuj-kamizelke-przypomni-o-uchodzcach.html

Kwiecińska-Zdrenka, M. (2018). Tworzenie Sprawiedliwych Miast - właczanie Agendy 2030 w polityki na poziomie lokalnym w czasach wielkich migracji i uchodźstwa. Toruń: Pracownia Badań Soma.

Łaciak, B. \& Segeš Frelak, J. (2018). The Wages of Fear. Attitudes Towards Refugees and Migrants in Poland. Warszawa: Instytut Spraw Publicznych.

Lasoń, M. (2018). 'Stanowisko polskich partii politycznych wobec problemu uchodźstwa i imigracji w drugiej dekadzie XXI wieku,' in Molo, B. (ed.) Migracja i uchodźstwo wyzwaniem dla bezpieczeństwa $i$ wspótpracy międzynarodowej w XXI wieku. Kraków: Krakowska Akademia im. Andrzeja Frycza Modrzewskiego, pp. 89-102.

Malkki, L. (1996). 'Speechless emissaries: Refugees, humanitarianism, and dehistoricization,' Cultural Anthropology 11(3), pp. 377-404

Mamzer, H. (2011). Czy warto ufać obcym? Poznań: Wydawnictwo Naukowe UAM.

Murdocca, C. (2003). 'When ebola came to Canada: Race and the making of the respectable body,' Atlantis 27(2), pp. 24-31.

My Poznań 36.6 (2017). Kampanie społeczne.pl. Available at: http://kampaniespoleczne. $\mathrm{pl} / \mathrm{my}$-poznan-366-walka-o-szacunek-dla-kazdego-czlowieka/ and www.youtube. $\mathrm{com} /$ watch? $\mathrm{v}=\mathrm{D} 46 \mathrm{DO} \mathrm{v} 4 \mathrm{CC} 44$

Never Again Association (2019). Selection of Islamophobic Events (for 2017-2018) Monitored in the 'Brown Book' Monitoring by the 'NEVER AGAIN' Association. Available at: www.nigdywiecej.org

Nyczka, T. (2016). "Wish you good luck and sunny days” Dzieci z Poznania piszą listy do swoich rówieśników uchodźców,' Gazeta Wyborcza, 18 December. Available at: http://poznan.wyborcza.pl/poznan/1,36001,21138828,i-wish-you-good-luck-a nd-sunny-days-dzieci-z-poznania-pisza.html

Nyczka, T. \& Żytnicki, P. (2015). 'Przeciwnicy i obrońcy imigrantów pikietowali w Poznaniu,' Gazeta Wyborcza, 18. July. Available at: http://poznan.wyborcza.pl/p oznan/1,36001,18386944,przeciwnicy-i-obroncy-imigrantow-pikietowali-w-pozna niu-przez.html

Pasamonik, B. (2017). 'Moral panic about refugees in Poland as a manifestation of cultural transformation,' Multicultural Studies 1, pp. 87-101.

Pędziwiatr, K. \& Legut, A. (2017). 'Polskie rządy wobec unijnej strategii na rzecz przeciwdziałania kryzysowi migracyjnemu,' in Wojtaszczyk, K. \& Szymańska, J. (eds) Uchodźcy w Europie. Uwarunkowania, istota, następstwa. Warszawa: Oficyna Wydawnicza Aspraa J-R, pp. 608-628.

Pędziwiatr, K. (2017). Islamophobia in Poland. National Report. Available at: www.islam ophobiaeurope.com/wp-content/uploads/2017/03/POLAND.pdf 
Pędziwiatr, K. (2018). 'The Catholic Church in Poland on Muslims and Islam,' Patterns of Prejudice 52(5), pp. 461-478.

Prończuk, M. (2017). Od dwóch lat rzad PiS blokuje środki unijne dla NGO-sów pomagajacych migrantom w Polsce. Za to daje $50 \mathrm{mln}$ euro na ,pomoc na miejscu.” Available at: https://oko.press/rzad-pis-daje-50-mln-euro-pomoc-miejscu-blokuje-srodki-unijnedla-ngo-sow-pomagajacych-migrantom-polsce/

Salwacka, S. (2017). “"Kogo uznajemy za bliźniego?” Debata, jak rozmawiać o uchodźcach. Może właśnie tak?' Gazeta wyborcza, 10 December. Available at: http://poznan.wyborcza.pl/poznan/7,36001,22764525,kogo-uznajemy-za-blizniegodebata-jak-rozmawiac-o-uchodzcach.html

Strani, K. \& Szczepaniak-Kozak, A. (2018). 'Strategies of othering through discursive practices: Examples from the UK and Poland,' Lodz Papers in Pragmatics 14(1), pp. $163-179$.

Sydow, K. (2017). '(Nie)widzialni mieszkańcy. Dyskurs o imigrantach i roli miasta w ich wspieraniu na przykładzie Poznania,' Studia Migracyjne - Przeglad Polonijny 2 (164), pp. 143-165.

Ticktin, M. (2006). 'Where ethics and politics meet: The violence of humanitarianism in France,' American Ethnologist 33(1), pp. 33-49.

Tracz, E. (2018). 'Stowarzyszenie Lepszy Swiat, "Tańczymy dla Syrii,” "Każdy może być mostem”,' in Kuligowski, W. (ed.), Miejsce oporu. O kontrkulturach kultury polskiej. Poznań: Biblioteka Czasu Kultury, pp. 149-156.

UrządMiastaPoznania (2017). Cudzoziemcy w Poznaniu. Available at: www.poznan.pl/m $\mathrm{im} / \mathrm{s} 8 \mathrm{a} /$ news/cudzoziemcy-w-poznaniu,110641.html-

Wigura, K (2016). Poland's Islamophobia. Available at: https://carnegieeurope.eu/stra tegiceurope/63892

Wrzosek, T. (2016). 'Discourse about refugees as a symptom of solidarity crisis,' Journal of Modern Science 1(28), pp. 411-430.

Wyrwał, M. (2017). Organizacje pozarzadowe na celowniku PiS. Mają dość, będa się bronić onet.pl. Available at: https://wiadomosci.onet.pl/tylko-w-onecie/organizacje-p ozarzadowe-na-celowniku-pis-maja-dosc-beda-sie-bronic/6mv1h1k 


\title{
18 Concluding thoughts
}

\author{
Elżbieta M. Goździak and Brigitte Suter
}

Dear Reader,

By now you have read several chapters describing and debating how national values are being transmitted to newly arrived refugees and immigrants in nine European countries. Various countries prioritize different values, but all countries argue that instilling 'shared values' in newcomers facilitates immigrant integration and social cohesion. While the idea of shared values as a benefit to society has recently become quite popular among European governments, the question remains: Is there convincing evidence that focusing primarily on shared values facilitates integration? Before answering this question, let's briefly recount some of the examples of value transmission, and the priority certain values are accorded.

France focuses on the 'values of the Republic.' They are part and parcel of the 'civic turn' (Mouritsen \& Jørgensen 2008) in immigration and integration policies implemented in a variety of European countries from the late 1990s onwards (Hachimi Alaoui \& Pélabay, this volume). The emphasis on 'shared values' is consistent with the directives of the European Commission and the Council of Europe (Pélabay 2011), as well as with the various civic education policies dedicated to the inculcation of the values shared by 'good citizens' (Kostakopoulou 2010). Adherence to the 'values of the Republic' is certainly thought to be a pre-requisite to successful integration into the French society.

In Germany, public debates about social and political cohesion have intensified since the terror attacks on the United States on 11 September, 2001. These debates, especially in conservative circles, have centered around the term Leitkultur (defining culture). The term was originally developed in an essay by the Syrian-born German academic Bassam Tibi (1996), who argued that Europe should define itself around core Enlightenment values vis-à-vis incoming migrants. With the recent migration of refugees to Germany, some Christian conservative politicians have revived the debate on Leitkultur (De Maizière 2017), while others have argued that 'shared values' (Zimmermann 2017) or 'Heimat' (lit: home) would be more neutral terms around which to center debates on the aims of integration. Still others have held that integration should not be understood in terms of shared values or 
cultural aspects at all, but should instead exclusively focus on social, economic, and political participation (Kipping 2017; Özoğuz 2017). It is noteworthy that the German government, at least in some instances, tries to distance themselves from the cultural connotations of Leitkultur. The government has increased funding for civil society initiatives focused on immigrant integration and has encouraged migrant-led organizations to get involved in integration, and to facilitate dialogue between incoming refugees, and the larger German society. It remains to be seen, however, whether Germany's new emphasis on shared values can avoid the assimilationist connotations it developed in the original Leitkultur debate (Herrmann, this volume).

In Italy, concepts such as deservingness and the community of value frame the debate about refugees in Italy (Marchetti, this volume). In order to gain access to certain rights, refugees have to prove that they deserve to receive refugee status and permission to remain in Italy. Only then they will be able to enter the 'community of value.' 'Communities of value' are imagined and socially constructed as communities populated by 'good citizens, law-abiding and hardworking members of stable and respectable families' (Anderson 2013: 3). Unlike the Others, these ideal citizens share values and patterns of behaviors, form 'the legitimate us,' and may therefore receive rights. Terms like 'immigrant, 'foreigner,' and 'asylum seeker' do not simply refer to immigration status, but are value laden and have negative connotations. As Aihwa Ong explains in her seminal study on Cambodian refugees in the US: to 'become "good enough" citizens, newcomers must negotiate among different forms of regulation, and be taught a new way of being cared for and of caring for themselves in their new world' (Ong 2003). In order to remain in Italy, refugees must acquire certain skills and prove that they understand what kind of values they need to adhere to in order to gain access to the 'community of value.'

'Swedish values' is a vernacular phrase used both by politicians and the general public. Explicitly tasked with conveying the country's values to newcomers, many providers of integration courses however are uncomfortable framing values and norms in cultural terms. Instead, they suggest that national legislation and international conventions on human rights are better suited to promote Swedish core values. Politically, the government has radically shifted its immigration stance. In order to ward off 'the crisis,' the government abandoned its previous quite open and humanitarian approach and replaced it with a more inward-looking approach. However, the Swedish civil society responded very positively to the asylum seekers arriving in Sweden in the fall of 2015. The civil society organizations enacted the values of solidarity, hospitality, equality, and compassion that form the basis of their ideology and activities (see Scaramuzzino \& Suter, this volume).

Poland and Hungary are true outliers among the countries under study. The Polish Constitution guarantees asylum seekers a right to asylum, but this right has been severely curtailed by the current government. Both 
Poland and Hungary, under the respective rule of the Law and Justice and Fidesz parties, have criminalized migration and presented refugees and asylum seekers as a threat to the security of Europe (Nagy 2016). Both countries emphasize that in order to preserve and protect 'European values,' admission of refugees, particularly Muslim refugees, is not desirable as values enshrined in Islam are not compatible with Christian European values (Goździak \& Márton 2018). Additionally, both countries feel threatened by liberal values promoted by the European Union, such as gender equality and respect for diversity. In Poland, both the Catholic Church and the government invoke the need to protect 'traditional family values' and see gender equality and respect for LGBTQ communities as an imminent threat to the country's national identity rooted in Catholicism. As Klaus (this volume) shows, Poland might not want refugees, but it needs labor migrants and has been quite open to migrants from Ukraine who seek employment in the country. Ukrainians are perceived by the Polish government as culturally close to Poles and therefore easier to integrate.

Pondering these examples makes one wonder whether the strong focus on shared 'European values' is as essential to immigrant integration as policymakers in Brussels and elsewhere believe. As we already discussed in the introduction, the term 'European values' has been contested. Even before the expansion of the European Union (EU) into Central and Eastern Europe in 2004, scholars have deliberated who and what counts as 'European' (Wagner 2005; Jeffrey 2008). A familiar binary - the making of the 'European' Self and the casting out of a 'non-European' Other is at the heart of such identity formation (Fleming 2003; Kuus 2004; Kuusisto 2004). With increased migration, these debates have intensified despite the fact that Europe has always been a diverse continent in which Christian, Muslim, Jewish, and secular traditions have been present for centuries (Goździak \& Main, this volume). The diversity of these traditions is what makes the cosmopolitan Europe vibrant and worth preserving, doesn't it?

Moreover, presenting shared 'European values' as rosy ideals and failing to acknowledge violations of values in the host society makes the value transmission efforts disingenuous. Additionally, in many countries the values presented as 'national values' are in fact liberal democratic values. Care needs to be taken not to conflate the two; otherwise the value transmission programs are nothing else but a top-down imposition of 'elite' values biased towards social and cultural norms of the majority. The challenge European policy-makers face is how to define values in non-ethnic and inclusive ways to signal to refugees and immigrants from day one that they are part of 'us' and an important element in ensuring social cohesion (Banulescu-Bogdan \& Benton 2017). Values based on ethno-cultural practices do not lead to positive integration outcomes in diverse societies (Hachimi Alaoui \& Pélabay, this volume). There is a need to engage newcomers in a thoughtful dialogue to identify what values they want to impart on their children as the second generation grows up in Europe. We might be pleasantly surprised at how much we all have in common. 
At the expense of sounding trite, we also want to emphasize that immigrant integration is affected by many factors (Goździak \& Martin 2005). Traditional immigration countries such as Australia, Canada, and the United States have always emphasized the importance of economic self-sufficiency. Therefore, providing refugees and immigrants with equitable access to the labor market even before they learned English had always been a number one goal of integration efforts. Ideally, newcomers would also receive a thorough orientation to the social mores, laws, and legal systems of their new country but understanding these traditions is not a substitute for decent employment, vocational training, and opportunities for upward mobility. Most of the countries under study include employment programs in their integration packets. It is important to provide refugees and immigrants with work permits as early as possible and integrate them into the labor market. Economically, opportunities for upward mobility represent a crucial incentive for newcomers to integrate themselves. Investment and professional advancement beyond ethnic businesses not only promote linkages with the host society but also help newcomers build foundations for their children. And finally, labor force participation not only provides migrants with sustainable livelihoods but also prevents social isolation.

While rights-based immigration and integration policies at the national level are important, action at the community level where the web of local relationships determines the immigrant experience, is equally if not more valuable. Experiences at local levels shape not only immigrant attitudes toward their new country but also the cohesiveness of the neighborhoods, towns, and cities they adopt as their new homes. In many different countries, local actors, including the newcomers themselves, have found novel ways to assume this responsibility and foster the incorporation of newly arrived immigrants into broader society. There is a need to increase participation of refugees and migrants, and ethnic community organizations in the decisionmaking processes in Brussels, in the capital cities, and in local municipalities. Local organizations need the support of national governments but they also need the opportunity for self-determination. The populist tendencies to present refugees and immigrants as a threat to 'European values' and traditions of tolerance, freedom, and democracy are misplaced. There is a need to change misperceptions that members of the host society and newcomers have of each other. Bridging the gaps that separate different groups would strengthen communities, mitigate divisive social tensions, and, of course, position immigrants to participate more effectively in the wider society.

The news media significantly influence the popular perception of refugees and immigrants, reinforcing stereotypes in some cases while empathizing with the foreigners' experiences in others. Particularly in areas with little previous ethnic diversity, the arrival of newcomers has attracted substantial news coverage, magnifying their presence. Newcomers' status - real or imagined - frequently influences the tone of the media's treatment. When asylum seekers are portrayed as 'irregular' or 'illegal' migrants or miscategorized as labor 
migrants, conflicts and accusations of greed and the desire to take social benefits from European citizens arise.

Regrettably, media coverage of immigrant issues frequently concentrates on moments of conflict between natives and newcomers, particularly in the aftermath of terrorist attacks. It is important to counter these misperceptions and inform the general public that most of the terrorists that launched attacks on European cities were born and raised in Europe. This begs the question: why were they radicalized? Perhaps they were easily lured by terrorist organizations because we failed to provide them with opportunities to thrive in society? In the context of the 'war on terror,' warnings against disenfranchisement of newcomers have taken on new resonance. Detentions of foreign-born residents are a high-profile example of what many have called a widespread erosion of immigrants' civil liberties. It is also important to support - with EU, national, and local programs and funds - media coverage of situations of cooperation and beneficial coexistence of migrants, refugees, and natives, based on individual narratives and academic research. There are many stories that could be written, films that could be made, plays that could be performed about thousands of positive, daily encounters when values are shared, discussed, learnt, and practiced.

Integration depends on the empowerment of immigrants for participation in the wider community. In both social and economic terms, it is important to stress opportunities and obligations as much as rights and entitlements. One of the largest obstacles to this goal is that mediating institutions such as local governments, schools, and mainstream civic organizations often overlook the newcomer voice. This condition is largely because of immigrants' lack of familiarity with their new communities. Links of incorporation within newcomer groups and with broad society remedy this condition over time, but initiatives undertaken shortly after migrants arrive in a particular locality have the potential to accelerate this orientation. We need to involve sports clubs, scouting organizations, faithbased and civil society organizations to lead by example and make integration as seamless and painless as possible.

The European Commission has scope to provide financial resources and non-monetary support to these kinds of initiatives. In particular, the Commission ought to strategize how to support refugee and immigrant youth as well as children of refugees and immigrants to ensure their civic and political participation in their respective countries. The tendency to see children of refugees and immigrants as growing up in migrancy is dangerous. Lena Näre (2013) views migrancy as 'the socially constructed subjectivity of "migrant" ... which is inscribed on certain bodies by the larger society in general and legislative practices in particular.... Very often the inscribed subjectivity of migrancy is not only attributed to those who have migrated' but also to children of immigrants, children who have never moved away from their place of birth. Increasing numbers of the world's children are growing up in this space, not because they are migrants themselves, but 
because their parents or even grandparents once were. We need to show these children that we value them and that they are part of us, not part of the foreign Others.

And finally, we want to call for an evidence-based approach to integration policy. There is a need to support robust and independent evaluation research focused not simply on outputs and to a certain extent outcomes of value transmission programs, but on long-term impacts. Participation of immigrants is important but bean-counting and box-ticking is not sufficient (Larruina \& Gorashi, this volume). The European Commission needs to find resources to support applied research, especially community-based participatory research where newcomers work hand-in-hand with academics in designing and implementing studies that will be useful to the refugee and immigrant communities, and thereby the whole society.

\section{References}

Anderson, B. (2013). Us Eु Them? The Dangerous Politics of Immigration Control. Oxford: Oxford University Press.

Banulescu-Bogdan, N. \& Benton, M. (2017). In Search of Common Values Amid LargeScale Immigrant Integration Pressures. Brussels: Migration Policy Institute Europe.

De Maizière, T. (2017). 'Wir sind nicht Burka,' BILD-Zeitung, April 29. Available at: www.bild.de/politik/inland/thomas-de-maiziere/leitkultur-fuer-deutschla nd-51509022.bild.html

Fleming, K. E. (2003). 'Orientalism, the Balkans, and Balkan historiography,' The American Historical Review 105(4), pp. 1-14.

Goździak, E. M. \& Martin, S. F. (eds) (2005). Beyond the Gateway: Immigrants in a Changing America. Lanham, MD: Lexington Books.

Goździak, E. M. \& Márton, P. (2018). 'Where the wild things are: Fear of Islam and the anti-refugee rhetoric in Hungary and in Poland,' Central and Eastern European Migration Review 7(2), pp. 125-151.

Jeffrey, A. (2008). 'Contesting Europe: the politics of Bosnian integration into European structures,' Environment and Planning D-Society and Space 26(3), pp. 428-443.

Kipping, K. (2017). 'Ein Land für alle - Bemerkungen zur Idee einer solidarischen Einwanderungsgesellschaft,' Berliner Reden zur Integrationspolitik. Available at: www. diw.de/de/diw_01.c.564717.de/publikationen_veranstaltungen/veranstaltungen/vera nstaltungsreihen/berliner_reden_zur_integrationspolitik/berliner_reden_zur_integra tionspolitik_archiv_kipping.html

Kostakopoulou, D. (2010). 'Matters of control: Integration tests, naturalisation reform and probationary citizenship in the United Kingdom,' Journal of Ethnic and Migration Studies 36(5), pp. 829-846.

Kuus, M. (2004). 'Europe's Eastern Expansion and the inscription of Otherness in East Central Europe,' Progress in Human Geography 28(4), pp. 472-489.

Kuusisto, R. (2004). 'Savage tribes and mystic feuds: Western foreign policy statements on Bosnia in the early 1990s,' in Hammond, A. (ed) The Balkans and the West Constructing the European Other 1945-2003. Aldershot: Ashgate.

Mouritsen, P. \& Jørgensen, K. E. (eds) (2008). Constituting Communities: Political Solutions to Cultural Conflict. Basingstoke: Palgrave Macmillan. 
Nagy, B. (2016). 'Hungarian asylum law and policy in 2015-2016: Securitization instead of loyal cooperation,' Special Issue Constitutional Dimensions of the Refugee Crisis, German Law Journal 17(6), pp. 1033-1082.

Näre, L. (2013). 'Migrancy, gender and social class in domestic labour and social care in Italy: An intersectional analysis of demand,' Journal of Ethnic and Migration Studies 39(4), pp. 601-623.

Ong, A. (2003). Buddha is Hiding: Refugees, Citizenship, the New America. Oakland, CA: University of California Press.

Özoğuz, A. (2017). 'Gesellschaftsvertrag statt Leitkultur: Leitkultur verkommt zum Klischee,' Tagesspiegel. 14 May. Available at: https:/causa.tagesspiegel.de/gesellscha $\mathrm{ft} /$ wie-nuetzlich-ist-eine-leitkultur-debatte/leitkultur-verkommt-zum-klischeedes-deutschseins.html

Pélabay, J. (2011). 'L'Europe des 'valeurs communes' et le recul du multiculturalisme: la diversité supplantée par l'unité?' Revue Philosophique de Louvain 109(4), pp. 747-770.

Tibi, B. (1996). 'Multikultureller Werte-Relativismus und Werte-Verlust,' Aus Politik und Zeitgeschichte B52-53(96), pp. 27-36.

Wagner, P. (2005). 'Hat Europa eine kulturelle Identität?' in Joas, H. \& Wiegandt, K. (eds) Die kulturellen Werte Europas. Bundeszentrale für politische Bildung. Berlin: Fischer-Taschenbuch.

Zimmermann, O. (2017). 'Man darf sich vor einer fremden Kultur fürchten,' Zeit online, December 27. Available at: www.zeit.de/politik/deutschland/2017-11/kul turelle-integration-leitkultur-werte-olaf-zimmermann-deutscher-kulturrat-interview 


\section{Index}

Amnesty International 15

Anne Frank House 30

Asia Minor 12, 14,16; identity 15; non-17; refugees 13, 15-19, 21; descendent 19-20

assimilation 13, 111-14, 132, 212, 220, 287

asylum 59-65, 190, 227-8, 248;

Common European Asylum System

(CEAS) 93, 105; information database

63; institution of 59-69; policy 91, 105, 107, 175, 201-2, 220, 228, 242,

248; right to $61,222,287$; seekers 1-9, 39-40, 63-4, 76-83, 92-3, 98-102, $149,152,154,159,166,175,185$, 201-2, 236-48, 287-9

Barroso, José Manuel 4, 122-3

Basic Law 59

border 5-7, 61-70, 82-3, 201-5, 221-2, 253-57, 263

Bourdieu, P. 156

Brexit 8, 185-9

Budapest 3

Camp des Milles 26-37

care 210; ethics 209-14; relationships 209-10

Centre of Asia Minor Studies 13

Charlie Hebdo 39, 114

Christianity: Christian charity 253; Christian Europe 3, 70; Christian identity 3, 272

civil society 43, 190, 248; actors 192; organizations (CSOs) 166-8, 170-1; support 201-3, 214 see also NGOs

citizenship 11, 121-2, 225-6, 242; citizen education 27-8

Cohen, Stanley 40 community 195, 224-6; of value 238-40, 287; sponsorship 186

consultation 52, 131; national 44, 67; process 167,181

cosmopolitanism 221-5; see also Swedish model

Court of Justice of the European Union (CJEU) 106

crisis $114,161,201,241$; narrative 1-3, 9; economic 151; Migration 13, 270-1; Refugee 59-60, 177-8, 201-3, 220 culture 67, 121-3, 226, 231, 273-5; European 44, 47; Leitkultur 286; national 39, 226; see also identity

democracy 53, 74, 122, 128

deportation 26-29, 262-3; detention 91-7, 104-7

deservingness 237-8, 246

detention 82, 290; centers 62, 240; see also deportation

Eastern Mediterranean, and Western Balkan route 14

ethnicity 33-4

ethnography 15, 246, 254

Europe: Central and Eastern Europe 74, 86, 288; European Council on Refugees and Exiles (ECRE) 1; European Court of Human Rights (ECtHR) 106, 162; European Migrant Advisory Board (EMAB) 8;

European Union (EU) 253, 281; Treaty (TEU) 3

equality 74 , 181; gender 115-16, 173; inequality 28, 239

Fassin, D. 162, 209, 239

Fidesz 41-3, 288 


\section{Index}

forced migration 205, 237-8; forced displacement 12-15; forced relocation 12 ; memories of 13 ; see also migration

foreigners $76,81-5$; undesirable $27-8,35$

France $27-8,112-16,253-4$

freedom 188-90

genocide $25,30-1$

Germany 59-60, 68-70, 91-2, 201-4, 286-7

government 39-42, 61-62, 85-86, 176, 220-2, 271-2

Greece 14-15, 76, 254, 278-80

Greek-Turkish population exchange $12-16$

Greeks 15-18; Greek Muslim 14; Greek Orthodox 14; Greek Paradox 19

Herrou, C. 253-6

Hirschon, R. 15-18

history $27-8,77-8,120,275$; histories of subjectivities 13-14; oral history approach 16; see also memory

Holocaust 26-9; memorial sites 30, 35

hospitality 35-6, 151-2, 178, 222-4

hotspots 13, 240, 263; operational 14; see also Moria

human rights $30-1,60,65-9,152-3$, $162-3,174,287$

humanism 149-53, 161

humanitarianism 181. 209-11, 280-1; duty 204; geography 14 ; organizations 1

Hungary 41-3, 47-50, 67-70, 204

identity $18,119,162,206-8$; and values $12,18,21$; national $61,113,186-7$, 225-6, 288

immigration 47-8, 168-9, 188-90, 225, 232, 289, ; anti-immigration discourse 79, 187, 274; economic 39; history of 75,76 , law $79,114,223-4$ see also policy

inclusion 128-34, 231-2

integration $74,111-14,168-70,196$, 213-14, 231, 286; conditional 117; contracts $111-12,117$

International Organization for Migration 2;

Islam 3, 35, 80-1, 112, 187-8;

Islamophobia $36,85,272$;

values 121,288
Italy 240-1, 263

Jews 27-31, 85, 156, 272

Kaczyński, Jarosław 271

Kara Tepe 13

Koselleck, R. 2

Kurz, S. 2

Kurdi, Alan 2

law 30-1 60-3, 79-80, 118, 261; asylum 83, 185, 221; European 87, 106; Rule of law 53, 74-5, 99, $102-7,188$

Law and Justice Party 81, 269-73

Lausanne Convention 14

Lesvos 12-14

Levi, Primo 29

Maas, Heiko 6

Macron, Emmanuel 25

media 39-42, 92-4, 269-70

Mediterranean Sea 278

memory 16-21, 30, 37, 256; collective 16, 21; contested 20; Family 17-18; memory of trauma 17 ; refugee memory $12-13,17-21$

Middle East 79-80, 154, 189

migration 5, 61, 79, 150, 168-9, 202, 259, 269 , 275; emigration 76,80 ; flows 12 , 278; see immigration; see policy; see crisis

migrants $39,82-3,114-17,222-4,228$, 240-4, 255-6, 273-5; interest of 142, $248,263-4$; reception of $8,36,150-4$; see also crisis

mobilization 158, 201, 256

Moria 13-14, 20

Multiculturalism 111, 180

Muslims 14-15, 36, 83-5, 121, 189, 272-3

narrative 13, 92, 123, 136, 232; counter139, 144; family 18; public 228 see also memory preservation

nationalism 86, 92, 149, 158, 223; postnationalism 226; cosmopolitanism and 230; racism and 272; rise of 26, 36; see also xenophobia

Netherlands 6, 8, 144

NGOs 274

norms 6, 130, 167-8, 187-8, 226, 288 ; European 1; legal 119-24; system of 161 ; see also values 
Orbán, Viktor 2-4, 39, 67-8, othering 6, 272; otherness 20, 210-12; fear of the other 29

panic: Moral panic button (MPB) 39-41

Poland 75-8, 269-76

participation 129-32, 144, 171-2, 186, 243-4; equal 128; political 287, 290; see also inclusion

policy: area 107, 167-8, 176-7; European $14,25,30,129$; immigration and integration $8,111,174,286$; migration 74-5, 111, 166, 220; policy-makers $112,139,202,227,288$

prejudice 15, 29-31, 177-8, 196

race $18,25,33,131,188,239$, racism 158, 187; attitudes 7 ; definition 26, 31; see also xenophobia

Rackete, Carola 6 reception 36, 128, 151-2, 236, 242-4 ; center 95, 174, 242, 247; project 257-9; system 161, 175, 236, 240-2, 255; see also refugee

Red Cross 167-8, 181, 255, 257; International Red Cross 172, Swedish Red Cross 171-2, 176-7, 179-80 refuge 27, 156; Refuge-city 149-51, 163 refugee: anti-refugee 274,279 ; attitudes 12, 80; definition 25, 248; influx 14, 61, 149, 209; Muslim 272, 288; protection $65,185-6,189-91$; reception 209-11, 213-14, 227-30; relocation 269-70; status 77-8, 178, 236-7; un/worthy 242, see also crisis

Rejection index 50

Religion 25, 81, 172, 276

resettlement 81, 173, 185-6

respect: respect for human dignity 3, 5, 74

rights: migrants' 209, 255, 265-6; to asylum $61-70,222,287$; to life 6; values and 4, 280; see also human rights Rogán, Antal 3
Salvini, Mateo 6, 236, 242

Simon, László L. 3 society $36,54,173,189$; host 21,111 , 124, 175, 224-5, 288-9; tolerant 196 solidarity: European 152, 271; symbols of 19

Spain 153-4, 161-2

sponsorship 185-6, 192-5

Sweden 166, 220

terrorism: terrorists 85, 271-2, 290; terrorist attacks 80, 114, 271, 290; war on 81

Third Republic 27-8, 35

Trilling, D. 4

Turkey 14, 68-9

Ukrainian workers 74,84

United Nations 47; High Commissioner for Refugees (UNHCR) 1; Refugee Agency 14

UNESCO 26-7

UNHCR 14, 25, 192-3, 237; see United Nations

United Kingdom 185, 196

values: democratic 26, 36; ethnocentric 43; of the Republic 8, 26, 111; pro-immigration 9, 269; value agent 91, 103-4; and norms 168, 178, 180-1, 287; see also European values

Ventimiglia 253-6

Vermeersch, P. 74, 79, 85-6

war: World War I 14; World War II 14, 83,220

welcoming: cities 156 ; culture 202; migrants 152, 162, 256, 265; rhetoric 149, 163; slogan 92, see also Willkommenskultur

Woollard, Catherine 1, 4, 6

xenophobia 85-6, 149, 229; racism and 26,37 ; rise of 13,158 ; xenophobic attitudes 43, 50, 92 


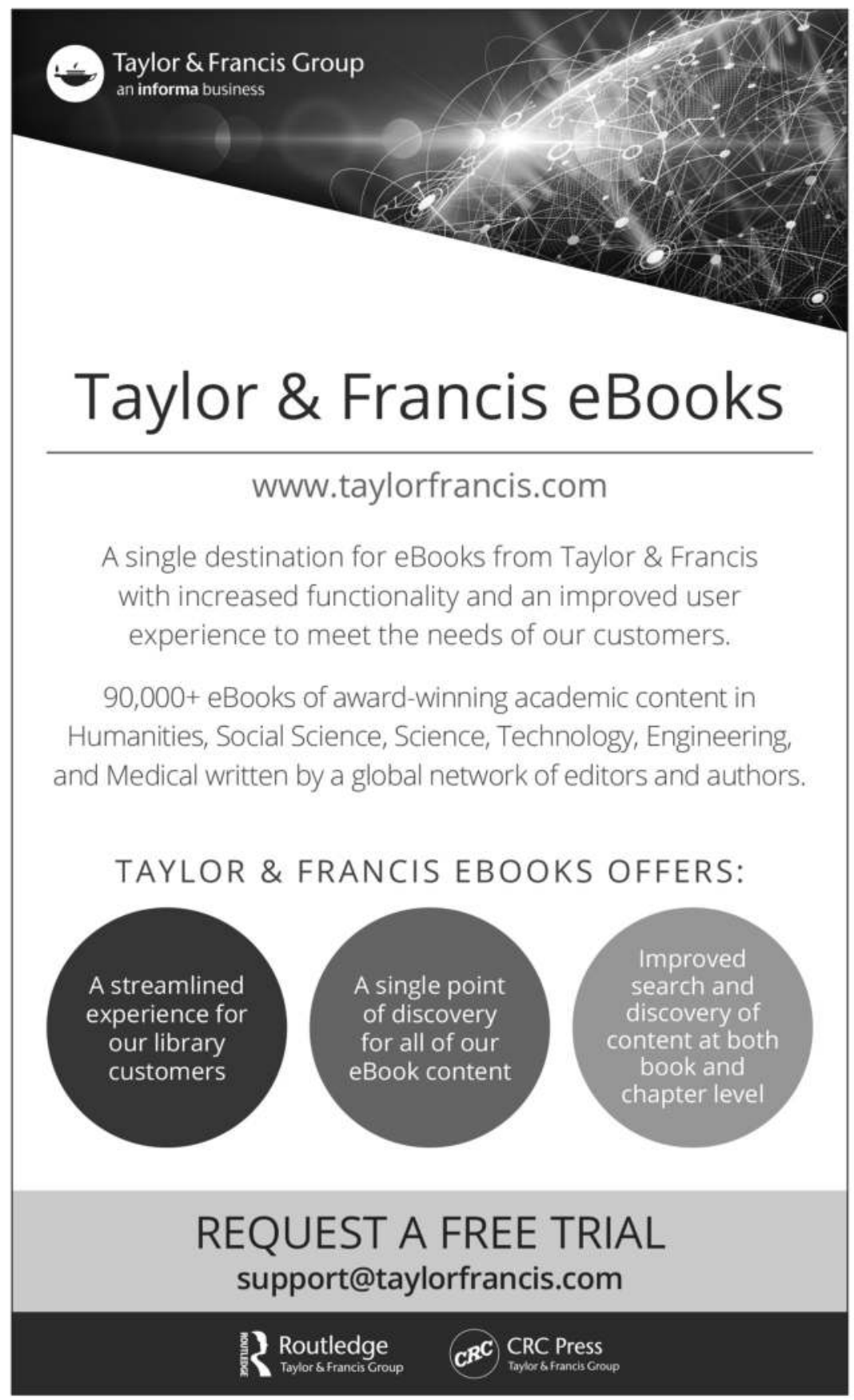

